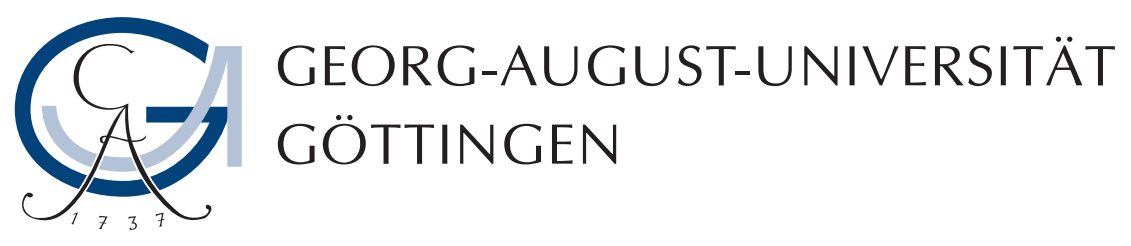

\title{
Firm Risk and Ambiguity: \\ The Role of Management and the Board
}

\author{
Dissertation \\ submitted to the Faculty of Business and Economics \\ at the Georg-August-Universität Göttingen
}

by

Sebastian Trabert, M.Sc.

from Fulda

Göttingen, May 7, 2021 
Thesis Committee:

Prof. Dr. Olaf Korn

Prof. Dr. Michael Wolff

Prof. Dr. Jörg-Markus Hitz 


\section{Contents}

List of Figures $\quad$ vii

List of Tables $\quad x$

1 Introduction 1

2 Do Younger CEOs Really Increase Firm Risk? Evidence from Sudden CEO Deaths 9

2.1 Introduction . . . . . . . . . . . . . . . . . . . . . . . . . . 10

2.2 Related literature and hypotheses . . . . . . . . . . . . . . . . . . . 14

2.2 .1 The risk-taking explanation . . . . . . . . . . . . . . . 14

2.2.2 The market knowledge explanation . . . . . . . . . . . . . . . 16

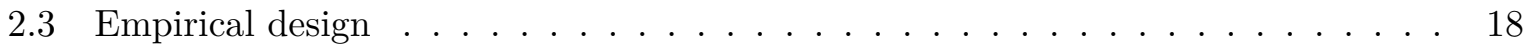

2.3.1 The sudden CEO death setting . . . . . . . . . . . . . . . 18

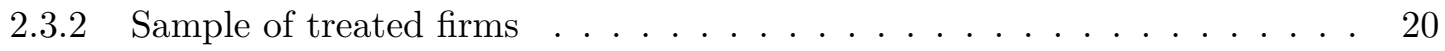

2.3 .3 Matching of control firms . . . . . . . . . . . . . . . . . 22

2.3.4 Difference-in-differences approach . . . . . . . . . . . . . . . . 24

2.3.5 Data and main variables . . . . . . . . . . . . . 27

2.3 .6 Descriptive statistics . . . . . . . . . . . . . . . . . 28

2.4 Main analyses . . . . . . . . . . . . . . . . . . . 30

2.4.1 CEO age and firm risk . . . . . . . . . . . . 30

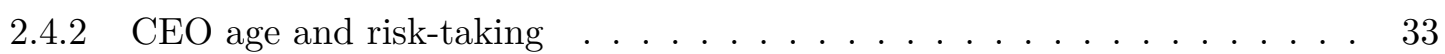

2.4.3 CEO age and the market's knowledge . . . . . . . . . . . 37

2.5 Additional analyses and robustness tests . . . . . . . . . . . . . 41

2.5.1 Parallel trends assumption . . . . . . . . . . . . . . . . 41

2.5.2 Alternative age change groups . . . . . . . . . . . . . . . . 43

2.5.3 Further robustness checks . . . . . . . . . . . . . . . . . . . 46

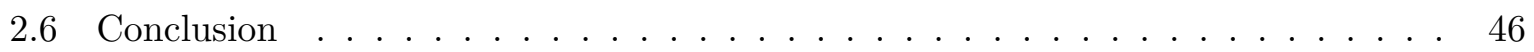




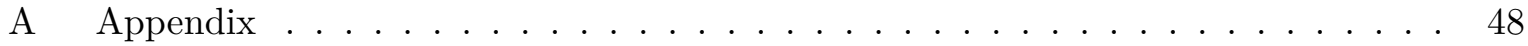

A.1 Derivation of the final sample of events . . . . . . . . . . . 48

A.2 Miscellaneous . . . . . . . . . . . . . . . . . 51

3 Board Size, Firm Type, and Stock Return Volatility 55

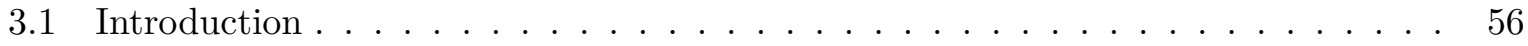

3.2 Data set and descriptive statistics . . . . . . . . . . . . . . . 62

3.2 .1 Data set . . . . . . . . . . . . . . . . . 62

3.2 .2 Defining firm types . . . . . . . . . . . . . . . . . 62

3.2 .3 Variables and descriptive statistics . . . . . . . . . . . . . 63

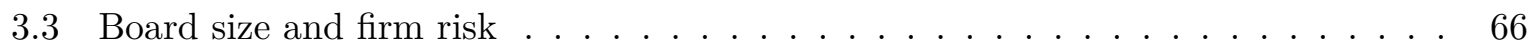

3.3 .1 Baseline regressions . . . . . . . . . . . . . . . . . . 66

3.3 .2 Idiosyncratic firm risk . . . . . . . . . . . . . . . . . 71

3.3.3 Robustness checks . . . . . . . . . . . . . . . . . . . 73

3.4 Endogeneity concerns $\ldots \ldots \ldots \ldots \ldots \ldots \ldots$

3.4 .1 Two-stage least squares estimation $\ldots \ldots \ldots \ldots$

3.4 .2 Dynamic panel GMM estimation . . . . . . . . . . . . . . 78

3.5 Testing the monitoring capacity and inefficiency explanations . . . . . . . . . 79

3.5.1 Evidence of board monitoring . . . . . . . . . . . . . . . 81

3.5.2 Board size and innovation inefficiency . . . . . . . . . . . . 85

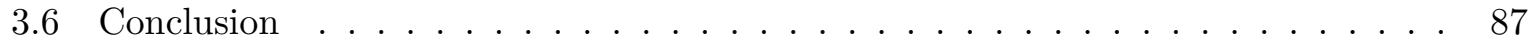

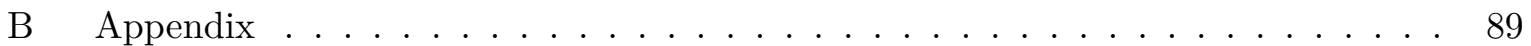

4 Board Structure and Ambiguity $\quad 91$

4.1 Introduction . . . . . . . . . . . . . . . . . . . . . . 92

4.2 Literature review and research question $\ldots \ldots \ldots \ldots \ldots$

4.3 Empirical approach and data set . . . . . . . . . . . . . . . . . . . . . 99

4.3.1 Listing rules and difference-in-differences design . . . . . . . . . . . . . . . 99

4.3.2 Propensity score matching . . . . . . . . . . . . . . . . . . . . . . 101

4.3.3 Data and variables . . . . . . . . . . . . . . . . . . . 103

$4.3 .4 \quad$ Descriptive statistics . . . . . . . . . . . . . . . . . . . . . . . 104

4.4 Results . . . . . . . . . . . . . . . . . . . . 108

4.4.1 Initial evidence of the effect on the VOV . . . . . . . . . . . . 108

4.4.2 Effect of board structure on the VOV . . . . . . . . . . . . . . 109

4.4.3 Do specific time periods drive the results? . . . . . . . . . . . . . . . . . 111 
4.4.4 Do certain firm characteristics matter? . . . . . . . . . . . . . . . . . . 114

4.4.5 Do information asymmetry and stock liquidity matter? . . . . . . . . . . 117

4.4 .6 Policy stability as a channel . . . . . . . . . . . . . . . . . . . 120

4.4.7 Are certain firms impacted differently? . . . . . . . . . . . . . . . . . . . . 124

4.4 .8 Additional robustness checks . . . . . . . . . . . . . . . . . . . . 128

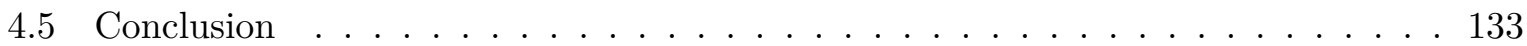

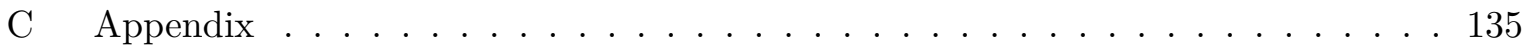

5 Conclusion $\quad 139$

$\begin{array}{ll}\text { Bibliography } & 143\end{array}$

$\begin{array}{ll}\text { Declarations } & 161\end{array}$ 



\section{List of Figures}

2.1 Mean volatility over time f . . . . . . . . . . . . . . . . . . . . 42

C.1 Board independence over time . . . . . . . . . . . . 135 



\section{List of Tables}

2.1 Overview of the retirement age groups $\ldots \ldots \ldots \ldots \ldots \ldots \ldots$

2.2 Overview of the age change groups $\ldots \ldots \ldots \ldots \ldots \ldots$

2.3 Summary statistics . . . . . . . . . . . . . . . . . . . 28

2.4 Treated vs. matched control firms before the event . . . . . . . . . . . . . . 29

2.5 Effect on volatility by (non-)retirement age CEO groups . . . . . . . . . . . 30

2.6 Effect on volatility by age change groups . . . . . . . . . . . . . . . 32

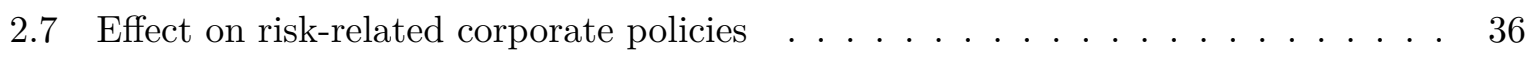

2.8 Does the tenure of the deceased CEO matter? . . . . . . . . . . . . . . 39

2.9 Does it matter if the deceased CEO was the founder? . . . . . . . . . . 40

2.10 Tests of the parallel trends assumption . . . . . . . . . . . . . 44

2.11 Effect on volatility by age change groups based on quartiles . . . . . . . . . 45

A.1 Derivation of the sudden CEO deaths sample . . . . . . . . . . . . 50

A.2 Variable definitions . . . . . . . . . . . . . . . . . . 51

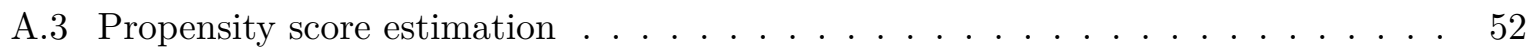

A.4 Control firm number taken . . . . . . . . . . . . . . . . . 53

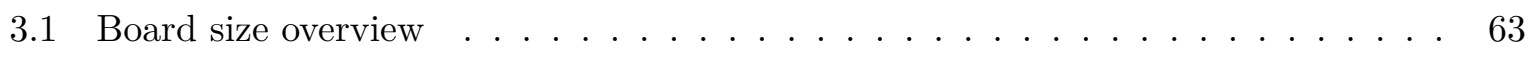

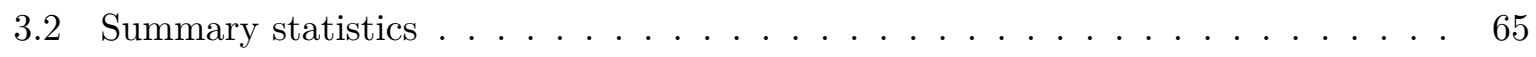

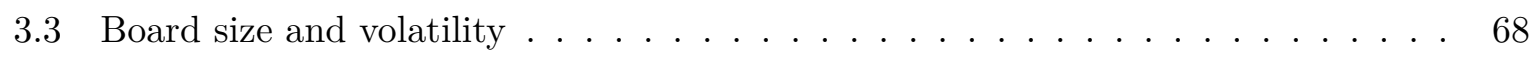

3.4 Board size and volatility by board categories f . . . . . . . . . 70

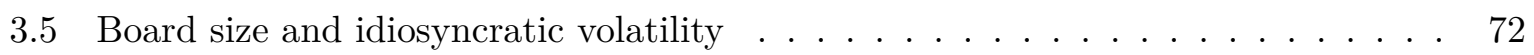

3.6 Board size and volatility by six board size categories . . . . . . . . . 75

3.7 Endogeneity-2SLS . . . . . . . . . . . . . . . 77

3.8 Endogeneity - Dynamic panel GMM estimation . . . . . . . . . . . . . . . 80

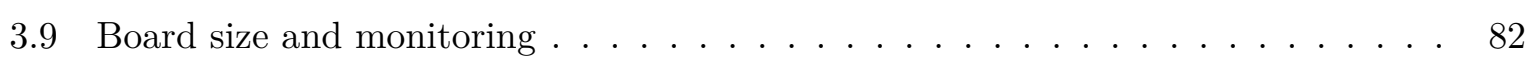

3.10 Board size and innovation across all firms $\ldots \ldots \ldots \ldots$

B.1 Variable definitions . . . . . . . . . . . . . . . . . . . . . . 89 
4.1 Summary statistics . . . . . . . . . . . . . . . . . 105

4.2 Treated vs. control firms in $2001 \ldots \ldots \ldots$. . . . . . . . . . 106

4.3 Univariate DID . . . . . . . . . . . . . . . . . . . . . . 108

4.4 Effect of board structure on the VOV . . . . . . . . . . . . . . 110

4.5 Do specific time periods drive the results? . . . . . . . . . . . . . . . . . 113

4.6 Further firm characteristics that matter . . . . . . . . . . . . . . . 116

4.7 Effect of information asymmetry and stock liquidity . . . . . . . . . . . 119

4.8 Effect of board structure on policy stability . . . . . . . . . . . . . . . 122

4.9 Effect in stable and dynamic industries . . . . . . . . . . . . . . . 126

4.10 Tests of parallel trends assumption . . . . . . . . . . . . . . . . 130

4.11 Robustness tests adding additional controls . . . . . . . . . . . . . . . . 132

C.1 Variable definitions . . . . . . . . . . . . . . . . . 136

C.2 Propensity score model estimation _ . . . . . . . . . . . . . . . 138 


\section{Introduction}

The separation of ownership and control that characterizes modern corporations gives rise to conflicts of interests between shareholders and managers (Berle and Means, 1932). These conflicts can be described as agency problems, as formalized by Jensen and Meckling (1976). They define an agency relationship as one in which "one or more persons (the principal(s)) engage another person (the agent) to perform some service on their behalf which involves delegating some decision making authority to the agent" (Jensen and Meckling, 1976, p. 308). In such a relationship, the agent cannot be expected to always act in the principal's best interest. Instead, because of conflicting goals and different attitudes toward risk between the principal and the agent (Eisenhardt, 1989), the agent can be expected to attempt to maximize his or her own utility by taking actions that, at least to some extent, negatively impact the principal's welfare. The costs associated with such agency problems are called agency costs (Jensen and Meckling, 1976). ${ }^{1}$ In the corporate context, shareholders (the principals), who are the owners of the firm, hire managers (the agents) to run the firm on their behalf. In principle, the task of the latter is to maximize shareholder value. However, self-interested managers can use their decision making authority to make investment, financing, and operating decisions that benefit themselves, yet are detrimental to the shareholders (e.g., Jensen, 1986).

In order to diminish or even prevent such detrimental managerial actions (i.e., to minimize agency costs), a collection of control mechanisms have been devised. Collectively, these mechanisms are summarized under the term corporate governance (Larcker and Tayan, 2021). Arguably, the most important corporate governance mechanism that shareholders can use to exert influence on management is the board of directors (John and Senbet, 1998). In its propositions for principles of a well-functioning corporate governance system, the Organisation for Economic Co-operation and Development (OECD), for example, summarizes the fundamental role of the board as follows:

\footnotetext{
${ }^{1}$ Jensen and Meckling (1976) define agency costs as the sum of monitoring and bonding expenditures as well as the residual loss, which represents the remaining deviation from the agent's actual action to the one that would have maximized the principal's welfare.
} 
"The corporate governance framework should ensure the strategic guidance of the company, the effective monitoring of management by the board, and the board's accountability to the company and the shareholders." (OECD, 2015, p. 45)

This description captures the board's two major functions, which are advising and monitoring management. In its advisory function, the board provides its expertise and counsels management in defining the firm's strategic direction to make sure that an appropriate balance between risk and reward is achieved. The monitoring function involves overseeing managerial actions to ensure that managers act in the shareholders' interests. This involves tasks such as assessing the management's performance, setting compensation, and - if necessary—hiring and firing the chief executive officer (CEO). Moreover, the board oversees financial reporting, legal and regulatory compliance, as well as internal control systems. Of course, there is overlap between the two board functions (Larcker and Tayan, 2021).

Research has extensively studied the role of the board of directors. ${ }^{2}$ The two main topics that have been addressed in this area of research are, first, the structure of the board and how it is determined, and second, the effect board structure has on board actions, such as hiring, firing, and compensating CEOs, as well as on firm performance measures, such as firm valuation or stock returns (e.g., Adams et al., 2010). Studies from the latter stream of research provide answers to the question of whether boards with certain characteristics, such as larger size or greater independence ${ }^{3}$, are more effective in fulfilling their assigned duties. Notably, while this question has received a lot of attention, the results on firm performance are not unequivocal (Boivie et al., 2016).

Recently, more and more studies have analyzed the relation of the board with another important market-based measure, namely firm risk, usually measured by the firm's stock return volatility (e.g., Cheng, 2008; Bernile et al., 2018; Giannetti and Zhao, 2019). However, corporate governance research has only started to directly focus on this important firm outcome that, as the basic finance principle of risk and return suggest, is inseparably linked to performance. Moreover, risk presents only one of two dimensions of uncertainty. The second one is ambiguity, which I will explain further toward the end of this chapter. Certainly, as I will explain below, shareholders

\footnotetext{
${ }^{2}$ For reviews of the literature on boards of directors see John and Senbet (1998), Fields and Keys (2003), Hermalin and Weisbach (2003), Adams et al. (2010), and Boivie et al. (2016).

${ }^{3}$ On a conceptual level, board independence refers to the degree to which the board is (un)likely to collude with the CEO. Usually, a board consisting of more outside directors is assumed to be more independent, since these directors may act as "professional referees" (Fama, 1980).
} 
care about both risk and ambiguity. To the best of my knowledge, no study has analyzed how board structure can affect the ambiguity associated with the firm.

This dissertation is fundamentally concerned with the question of how management and board structure influence corporate uncertainty. It thus contributes to the developing literature linking specific CEO or board characteristics to risk-related corporate outcomes. In three separate studies, I address particular topics within this context. The first study (Chapter 2) focuses on the influence of the CEO on firm risk with a particular focus on CEO age. In the second study (Chapter 3), I turn to the board and examine the relation between its size and firm risk. Finally, the third study (Chapter 4) analyzes the board's influence on ambiguity, with the characteristic of interest being board independence. In the following, I will motivate and briefly summarize each of the three studies. The studies will then be presented in Chapters 2 through 4 .

The first two studies focus on firm risk, which is relevant in the corporate context for several reasons. First, the different attitudes of managers and shareholders toward risk have been identified as a primary source of agency problems, thus compromising shareholder value maximization (Amihud and Lev, 1981; Holmström and Ricart I Costa, 1986; Eisenhardt, 1989). Second, the two major board functions described above are directly linked to managing and controlling the riskiness of the firm. When advising management, a major concern of the board is to ensure that the firm's strategy entails an appropriate balance between risk and reward. In addition, oversight of the firm's risk management is an important part of the board's monitoring duty. This task includes determining the firm's risk profile, ensuring that the firm is aware of potential risks, effectively manages them, and permanently operates at an appropriate risk level (Larcker and Tayan, 2021). Third, major corporate collapses, such as Lehman Brothers or Bear Stearns during the 2008 financial crisis, underscore the severe consequences excessive risk-taking can have when boards fail to meet their duty to appropriately oversee the firm's risk management (Kirkpatrick, 2009). In sum, both management and the board are seen as important actors influencing the riskiness of the firm and a functioning board should encourage risky but value-enhancing decisions, yet prevent unnecessary risks caused by excessive risk-taking.

I begin with the perspective on the management's influence on firm risk. As outlined above, agency theory highlights differences in the managements' and shareholders' attitudes toward risk as a major reason for agency problems (Eisenhardt, 1989). The general assumption is that managers are more risk-averse than shareholders, who hold diversified portfolios through which they can achieve their desired level of risk. Managers, on the other hand, whose income 
primarily depends on the firm, are not able to diversify their employment risk. Hence, they have incentives to pursue strategies that reduce firm risk below the level that would be optimal for the shareholders (e.g., Amihud and Lev, 1981). However, extensions of the classical agency model relax the assumption of risk-averse managers (e.g., Harris and Raviv, 1979), suggesting a more multifaceted view on managerial attitudes toward risk. Accordingly, an evolving literature shows that the riskiness of the firm varies with individual characteristics of managers that reflect their preferences and attitudes toward risk. These studies, for example, associate a CEO's experience of early-life disasters (Bernile et al., 2017), behavioral traits such as optimism and risk-aversion (Graham et al., 2013), sensation-seeking (Cain and McKeon, 2016), or social capital (Ferris et al., 2017) with different levels of firm risk. Consequently, heterogeneity in individual preferences and attitudes toward risk appear to be a likely reason leading managers to deviate from what would be the optimal level of risk for shareholders. Such deviations represent a classical agency conflict and it is one of the tasks of the board to resolve it.

Given this background, the first study (Chapter 2) focuses on the influence of a particular CEO characteristic, namely CEO age, on firm risk. By using a setting that better accounts for endogeneity problems inherent in many related studies, I challenge and extend the findings of two recent studies that explain increased (decreased) firm risk associated with younger (older) CEOs with a tendency of such CEOs to take on more (less) risk-related corporate policies (Serfling, 2014; Peltomäki et al., 2020). To that end, I use data on sudden CEO deaths, which allows me to better address endogeneity concerns and to draw causal inferences from the analyses. The empirical approach of my study can be briefly summarized as follows. I initially compile a matched sample of "treated" firms, which experienced a sudden CEO death, and "control" firms that did not change their CEO at the time. For both groups of firms I then hand-collect data on the CEO history around the time of the sudden deaths and conduct difference-in-differences (DID) analyses to examine whether the changes in CEO age induced by the sudden deaths lead to long-term changes in firm risk for the treated firms, compared to their matched control firms. In the analyses, I also account for the endogenous choice of the successor CEO.

I find that younger (older) CEO age indeed increases (decreases) firm risk, measured as stock return volatility, which substantiates the findings of Serfling (2014) and Peltomäki et al. (2020). However, I find no indication that CEO age also negatively influences the CEOs' risk-related policy choices, which clearly contradicts the explanation provided in these studies. Rather, I consider and test an alternative explanation for the effect, namely that increased firm risk is caused by the market's lack of knowledge of the younger CEOs' abilities. I find evidence in favor 
of this alternative explanation. Overall, the findings of this study enhance the understanding of how CEO age affects firm risk, while highlighting the importance of accounting for endogeneity. With respect to the overall topic of this dissertation, this study shows that - other than suggested by the results of previous studies - CEO age does not appear to be a characteristic that leads a CEO to implement risk-related policies according to his or her personal preferences. Thus, the board does not have to put a particular focus on a CEO's age with regard to his or her risk-taking behavior. In fact, it could be of importance for the board to help enhance the market's knowledge about the CEO, for example, by fostering good communication when an unknown CEO is selected or by choosing a well-known CEO in the first place, to control this portion of firm risk.

Next, I directly focus on how the board affects the riskiness of the firm. Ideally, an efficiently functioning board interacts with management in a way that encourages risky but value-enhancing decisions, while at the same time preventing excessive risk-taking. Some studies have associated specific aspects of board structure with measures of firm risk. Board size in particular has shown to be an important determinant of firm risk, with larger boards being associated with lower variability of corporate performance and less risky policy choices (Cheng, 2008; Wang, 2012). More recently, board diversity (Bernile et al., 2018), board ancestral diversity (Giannetti and Zhao, 2019), and authority concentration within the board (Tran and Turkiela, 2020) have also been shown to moderate the riskiness of the firm.

The second study ${ }^{4}$ (Chapter 3) revisits the relation between board size and firm risk. Specifically, we consider and test two competing explanations that might explain the negative relation that has been illustrated by existing studies (Cheng, 2008; Wang, 2012). The first explanation is the one presented by Cheng (2008), who reasons that inefficiencies, that is, communication and coordination problems, occurring in large boards may drive the reduction in firm risk. Since this explanation implies that larger boards are less able to function properly, reduced volatility would be a negative development for the shareholders. We consider an alternative explanation that highlights the benefits large boards may provide. Since larger boards can possess a greater capacity for monitoring (e.g., Boone et al., 2007), they might reduce unnecessary risk. Hence, reduced risk associated with larger boards could be a positive outcome for shareholders. To empirically test both explanations, we use a large U.S. panel data set and not only analyze the relation of board size with firm risk, but also with several firm outcomes indicative of

\footnotetext{
${ }^{4}$ This study is joint work with Alexander Merz.
} 
monitoring or inefficiencies. Moreover, we conduct separate analyses for two specific firm types, namely complex and high-growth firms, for which we have different expectations regarding which explanation applies. While we expect complex firms to benefit from greater monitoring capacity of large boards, inefficiencies should manifest in high growth firms at comparatively smaller board sizes already. In additional analyses, we address endogeneity concerns by conducting an instrumental variable and a generalized method of moments (GMM) approach.

Our analyses show that board size is negatively related to firm risk across all firms as well as for both firm types. For high-growth firms, board size reduces firm risk significantly faster (i.e. at lower board sizes), compared to low-growth firms. Importantly, by analyzing outcomes such as forced CEO turnover and earnings management, we find evidence in favor of the monitoring capacity explanation across all firms as well as for complex ones, suggesting that the reduction in firm risk most likely stems from better monitoring and, thus, from avoiding unnecessary risk. For high-growth firms, on the other hand, we find evidence that innovation quality decreases with board size, which is in line with the notion of inefficiencies driving the reduction in firm risk. Overall, our findings contribute to the growing literature on the influence of specific board characteristics on firm risk. In contrast to the view presented in prior studies, we illustrate that larger boards can provide advantages to certain firms. Furthermore, our results highlight that differentiating between different firm types can improve the understanding of the board's functionality.

While, so far, the focus has been on firm risk, I now turn to the second dimension of uncertainty. In his seminal work, Knight (1921) introduces the dichotomy between risk and ambiguity. He famously notes that "Uncertainty must be taken in a sense radically distinct from the familiar notion of Risk, from which it has never been properly separated" (Knight, 1921, p. 19). What he is referring to in his quote is nowadays more commonly referred to as ambiguity or Knightian uncertainty. The main difference between the two dimensions of uncertainty lies in the possibility of economic actors to assess unknown future outcomes. While risk refers to scenarios in which the probabilities of the potential outcomes are known, ambiguity means that these probabilities are either also unknown or not uniquely assigned (e.g., Knight, 1921; Izhakian, 2020). In other words, "[r]isk is the uncertainty of outcomes, while ambiguity - Knightian uncertainty —is the uncertainty of the probabilities of outcomes" (Herron and Izhakian, 2020, p. 1). In many situations, ambiguity affects the decisions of economic actors very differently than risk does. That is, in the presence of ambiguity it becomes more difficult for them to get a clear understanding of the potential consequences of their decision. As a result, they overvalue negative and undervalue positive 
outcomes, which decreases the attractiveness of possible investment opportunities (Agliardi et al., 2016; Herron and Izhakian, 2018). In line with these detrimental effects, economic actors have been shown to exhibit ambiguity aversion (Ellsberg, 1961). Even though the concept of ambiguity is not at all new, corporate finance research has only recently begun to analyze this second dimension of uncertainty theoretically (e.g., Agliardi et al., 2016; Garlappi et al., 2017) and empirically (e.g., Izhakian and Yermack, 2017; Izhakian et al., 2021). To the best of my knowledge, no study exists that analyzes the influence of the board on firm-level ambiguity.

The third study ${ }^{5}$ (Chapter 4) is the first to examine the board's influence on firm-level ambiguity. We focus on what is arguably the most important board characteristic, namely the board's independence. Because of the generally detrimental effects ambiguity has on shareholders, we argue that a board acting in the shareholders' interests should reduce ambiguity, which managers may inadvertently create through their policy decisions. In particular, independent directors can achieve ambiguity reduction by using their influence on the board to induce more predictable, less fluctuating corporate policies that are easier for shareholders to understand and to evaluate. Empirically, our identification strategy rests on the NYSE and NASDAQ listing rule changes introduced in 2003, which required listed U.S. firms to have majority independent boards. These rule changes presented a quasi-exogenous shock to board independence for all firms not in compliance with that regulation (i.e., the "treated" firms). Firms that were already compliant serve as "control" firms throughout the analyses. We exploit this setting by conducting DID analyses on a propensity score matched sample of treated and control firms. As our measure of ambiguity, we use the volatility of volatility (VOV) of stock returns, which has a direct link to (fluctuating) risk-related corporate policy decisions and should, thus, serve as a suitable aggregate ambiguity proxy.

Our results show that the listing rule changes indeed reduced firm-level ambiguity (i.e., the VOV) for the treated firms by statistically and economically significant margins. In line with the idea that this reduction can be achieved through policies that are easier to understand and to evaluate, we also find that increased board independence led to lower fluctuations in several firm policies, such as total investments, cash holdings, or financial leverage. Firm values, however, only increased in stable industries, while they declined in dynamic ones. In the latter environment independent directors seem to prevent necessary changes. Overall, our study enhances the knowledge about the role of the board in several ways. First, we are the first to show that board

\footnotetext{
${ }^{5}$ This study is joint work with Alexander Merz.
} 
structure can reduce ambiguity for shareholders. Second, we enhance the understanding of the impact of independent directors, who likely achieve the ambiguity reduction through inducing more stable policies. Third, we show that governance reforms, such as the listing rule changes, can reduce ambiguity, yet that this effect appears to be beneficial only for firms not operating in frequently changing environments.

The studies constituting this dissertation are of relevance for several interest groups. Above all, they address an audience in academia. All three studies contribute to the understanding of how key actors in the corporate context affect uncertainty associated with the firm. Moreover, each study illustrates opportunities that should be considered by future research. The first study demonstrates an empirical approach that can be used to generate causal evidence on the influence of characteristics of corporate executives; the second study highlights the importance of differentiating between different firm types when analyzing the impact of corporate governance mechanisms; and the third study illustrates a way to reduce firm-level ambiguity. Future research can identify further mechanisms through which ambiguity can be influenced. Moreover, the insights from the three studies are of relevance for shareholders or policy makers who are concerned about implementing functioning corporate governance mechanisms. Specifically, they provide additional evidence of the effectiveness of crucial board characteristics and support critics of one-size-fits-all approaches in corporate governance regulation. 


\title{
2 Do Younger CEOs Really Increase Firm Risk? Evidence from Sudden CEO Deaths
}

Submitted to the Journal of Corporate Finance.

\begin{abstract}
This study uses 131 sudden deaths of chief executive officers (CEOs) and a hand-collected data set of the firms' CEO history to provide causal evidence on the relation between CEO age and firm risk. I find that CEO age negatively influences firm risk, measured by stock return volatility, thereby substantiating the findings of recent studies. However, I find no indication of a negative effect on risk-related policy choices, which stands in clear contrast to the empirical findings and explanations provided in these studies. Rather, further tests indicate that higher volatility is caused by the market's limited knowledge of younger CEOs.
\end{abstract}

Acknowledgments: I thank Jörg-Markus Hitz, Olaf Korn, Alexander Merz, and Michael Wolff as well as seminar participants at University of Goettingen for their comments and suggestions. I also thank Malte Bartel, Yannik Prampain dit Boulan, and Michael Überscher for excellent research assistance. All remaining errors are my own. 


\subsection{Introduction}

The chief executive officer (CEO) is arguably the most important individual in a firm, and an abundance of literature highlights that his or her characteristics and preferences matter for corporate policies and outcomes (e.g., Bertrand and Schoar, 2003; Malmendier and Tate, 2008; Kaplan et al., 2012; Graham et al., 2013; Bernile et al., 2017; Bennedsen et al., 2020). One characteristic that has received particular attention is the CEOs' age. Theoretical and empirical studies have predominantly conveyed an image of the "impetuous" and "restless" youngsters who "lead busy lifes," whereas older CEOs are framed as "jaded old-timers" who are reluctant to take risks (e.g., Hambrick and Mason, 1984; Prendergast and Stole, 1996; Yim, 2013; Zhang et al., 2016). In line with that view, two recent empirical studies associate younger CEOs with greater firm risk, which is measured as stock return volatility, and suggest that this is due to their propensity to take on riskier corporate policies (Serfling, 2014; Peltomäki et al., 2020). ${ }^{1}$ However, since their empirical approaches mostly consist of fixed-effects regressions on large panel data sets, their results may be subject to endogeneity biases.

In the present study, I examine the relationship between CEO age and firm risk using data on sudden CEO deaths. ${ }^{2}$ This setting provides several advantages over basic fixed-effects regressions or regular CEO turnovers. First, sudden deaths lead to a change in the CEO that is clearly induced by exogenous factors (Fee et al., 2013) and does not result from weak performance, an intended change in corporate policies, or firm risk. Changes in firm policies and outcomes following such an exogenous turnover can thus be directly attributed to the change in the CEO and his or her characteristics, allowing for the identification of a causal link running from the (change in the) CEO to firm policies and outcomes and not the other way around. Second, they are - by definition - unexpected and, thus, could not have been foreseen by the market. This facilitates clear identification of the effect of the change of CEO. Third, they allow for identifying the differential effect that two CEOs - the deceased and his or her successor-have in one firm compared to firms that did not change their CEO, using a difference-in-differences (DID) approach. Collectively, the use of sudden deaths helps alleviate endogeneity concerns inherent in many related studies (Fee et al., 2013). Therefore, this study challenges existing findings on the

\footnotetext{
${ }^{1}$ In accordance with the literature, I refer to firm risk as the market-based risk reflected in the firm's stock return volatility, while risk-taking subsumes the actions taken by management to shape risk-related corporate policies, which eventually influence firm risk (e.g., Kini and Williams, 2012; Serfling, 2014; Cain and McKeon, 2016; Bernile et al., 2017).

${ }^{2}$ Sudden deaths are those that occurred "instantaneously or within a few hours of an abrupt change in the person's previous clinical state" (Nguyen and Nielsen, 2010, p. 553). The reasons for such deaths, for example, include accidents, murder, or sudden medical issues such as heart attacks or strokes.
} 
relationship between CEO age and firm risk.

Existing studies predominantly explain the relation between CEO age and firm risk with reference to CEOs' influence over fundamental risk-related policy choices, which eventually impact firm risk. This risk-taking explanation is based on several theoretical studies that provide arguments in support of both a positive and negative relationship between managers' age and their risk-taking behavior. While career concerns decrease (increase) the tendency of younger (older) managers to take risks (e.g., Zwiebel, 1995; Holmström, 1999), the willingness to acquire reputation (Prendergast and Stole, 1996) increases (decreases) it. Moreover, psychological biases and physiological limitations may lead older managers to refrain from risky policy decisions (e.g., Hambrick and Mason, 1984). Empirically, Serfling (2014) and Peltomäki et al. (2020) find evidence in favor of a negative relation between CEO age and risk-taking by negatively associating CEO age with investments in research and development $(\mathrm{R} \& \mathrm{D})$ and operating leverage and positively with corporate diversification.

However, since analyses of exogenous CEO turnovers cast doubt on the notion of a CEO-specific influence on the firms' policies (Fee et al., 2013), I also consider an alternative explanation that is based on the learning model developed by Pan et al. (2015). The authors highlight another source of firm risk (i.e., stock return volatility) that is distinct from that caused by fundamental policy choices, namely, uncertainty about the CEOs' abilities. As the market's knowledge concerning younger CEOs is likely to be considerably limited compared to that of their older colleagues, higher stock return volatility could, thus, be caused by the resulting uncertainty about how they will affect future profits rather than by fundamental policy choices. This study is the first to consider this market's knowledge explanation in the context of CEO age.

I empirically examine the relationship between CEO age and firm risk using data pertaining to 131 sudden CEO deaths that occurred in listed US firms between 1952 and 2014. To each of these 'treated' firms, I match one similar control firm that did not change their CEO at the time by applying a propensity score matching (PSM) procedure. I then hand-collect data on the CEO histories of both the treated and control firms for the four years prior to and the four years after the sudden death events. I conduct DID analyses on the resulting sample to determine whether changes in CEO age induced by sudden deaths led to changes in firm risk for the treated firms. I also conduct tests that address the endogenous selection of the successor CEO.

I begin the empirical analyses by focusing on the relationship between CEO age and firm risk, 
as measured by (idiosyncratic) stock return volatility. ${ }^{3}$ To determine the effect of CEO age, I conduct two separate DID approaches. First, I estimate the treatment effect for firms in which the deceased had reached or exceeded 65 years - the typical retirement age for US CEOs (Jenter and Lewellen, 2015), thereby addressing the endogenous nature of the successor's selection. Since these firms had virtually no option but to lower CEO age, not only is the reason for the CEO turnover exogenous but also the need to appoint a younger successor. I find that for those firms, (idiosyncratic) volatility increased significantly in the years following the sudden deaths, ${ }^{4}$ whereas no such effect is evident for firms with younger deceased CEOs. Second, I define three 'age change groups' and estimate the treatment effect for each. This yields insights into the age difference at which the effect occurs. In line with the earlier studies' results, I find that (idiosyncratic) volatility increased significantly for firms that lowered CEO age by large margins, yet no effect is observed for firms with moderate decreases or firms that did not decrease CEO age. Overall, the results of both analyses support the notion that CEO age negatively influences firm risk.

Next, I focus on the two possible explanations that may account for this baseline result. I first test whether the risk-taking explanation holds true in the present study's setting. Again, I conduct both analyses (i.e., the retirement age analysis and the analysis by age change groups) to determine whether changes in CEO age induced by sudden deaths led to changes in those risk-related corporate policies. Following Serfling (2014), I analyze investments in R\&D, firm diversification, operating leverage, and financial leverage. I find no evidence to indicate that reductions in CEO age lead to increases in risk-related policies, which clearly contradicts the risk-taking explanation and stands in contrast to the results reported by Serfling (2014) and Peltomäki et al. (2020).

I then perform tests to assess the market knowledge explanation, focusing on circumstances in which I expect the differences in uncertainty regarding the deceased CEO and his or her successor to be great. The appointment of a much younger, unknown successor in a situation in which the deceased was particularly well known to the market is expected to significantly increase CEO-related uncertainty such that the increase in volatility is likely to be more pronounced. To test this conjecture, I re-perform the baseline firm risk analyses on subsamples of firms in which the deceased had enjoyed long tenure or had been one of the firm's founders. I find that the

\footnotetext{
${ }^{3}$ Stock return volatility is calculated as the annualized standard deviation of daily stock returns, obtained from the Center for Research in Security Prices (CRSP). Idiosyncratic volatility is the annualized standard deviation of daily residuals from Fama-French three-factor model estimations.

${ }^{4}$ Note that I exclude the year of the sudden death from the analyses. Hence, I find a longer-term increase in volatility, rather than a short-term increase in the aftermath of these events.
} 
increase in volatility is particularly strong in these subsamples, providing evidence in favor of the market's knowledge explanation.

Finally, I conduct several additional analyses that should further strengthen the validity of my results. These analyses include tests for the crucial parallel trends assumption, alternative age change group definitions, and further robustness checks addressing the choice of the sudden deaths considered, as well as the choice of the sample period.

This study contributes to the literature in several ways. First and foremost, I contribute to the literature examining the relation between CEO age and firm risk in two ways. First, my findings substantiate those pertaining to firm risk (i.e., volatility) reported by Serfling (2014) and Peltomäki et al. (2020) by permitting a causal interpretation that runs from CEO age to firm risk. Second, I provide an alternative explanation for the relationship that focuses on the market's knowledge of the CEOs. My tests provide evidence that favors this explanation over the hitherto accepted risk-taking explanation.

Moreover, I contribute to the literature on the relationship between CEO age and risk-related corporate policy choices (e.g., Barker and Mueller, 2002; Serfling, 2014; Zhang et al., 2016; Croci et al., 2017). My findings cast doubt on the influence of CEO age on risk-related policy decisions. Since I find no effect of CEO age on certain policies using a setting that accounts for the endogenous nature of such analyses, causal interpretations of some of the findings reported by related studies should, at least, be viewed with caution.

More broadly, I contribute to the literature by investigating the relationship between CEO characteristics and corporate policies and outcomes. In using sudden deaths to analyze the relationship between a specific characteristic and firm risk, I suggest a new avenue to generate more causal evidence on how CEO characteristics influence firm policies and outcomes.

The remainder of the paper is organized as follows. Section 2.2 develops the hypotheses. Section 2.3 illustrates the empirical design, including the sample construction and descriptive statistics. Section 2.4 presents the results for the main analyses. Section 2.5 presents the results for additional analyses as well as robustness checks. Finally, Section 2.6 concludes the paper. 


\subsection{Related literature and hypotheses}

\subsubsection{The risk-taking explanation}

Existing studies on the relationship between CEO age and firm risk predominantly base their argumentation on the influence that executives exert over fundamental corporate policies. More specifically, they argue that individual age-related characteristics and preferences, such as career or reputation concerns, impact risky policy choices that executives make and that this consequently affects their firms' risk level (Serfling, 2014; Peltomäki et al., 2020). I will refer to this as the risk-taking explanation.

A priori, it is not clear whether executives' ages should increase or decrease their tendency to take risks, particularly since the literature offers reasons for both possibilities. Theoretical studies that predict a positive relationship - that is, that risk-taking behavior increases with age - base their arguments primarily on the issue of career concerns, which are assumed to be higher for younger managers owing to their longer career horizons (Gibbons and Murphy, 1992). Holmström (1999) demonstrates that young managers refrain from risky investments to avoid being evaluated as untalented. For the same reason, they avoid value-enhancing projects that are associated with high risk of early failure (Hirshleifer and Thakor, 1992). Moreover, career concerns cause managers to exhbit 'herding behavior', simply mimicking the investment decisions of others (Scharfstein and Stein, 1990), and to undertake inferior standard actions because they are evaluated relative to their industry peers (Zwiebel, 1995). All such actions will eventually result in overly conservative policy decisions on the part of younger managers, supporting the notion of a positive relationship between CEO age and risk-taking behavior.

However, the empirical evidence supporting this positive relationship is scarce and, with the exception of a single study, does not focus on CEOs. The exception is Gormley and Matsa (2016), who demonstrate that career concerns lead younger CEOs to 'play it safe', meaning that they make more diversifying acquisitions than older CEOs. Similarly, a greater risk of being dismissed as a result of weak performance leads younger mutual fund managers to hold portfolios that include less unsystematic risk (Chevalier and Ellison, 1999) and discourages inexperienced security analysts from deviating from the consensus forecast (Hong et al., 2000). Additionally, Lamont (2002) demonstrates that younger macroeconomic forecasters produce less radical forecasts as a result of reputation concerns.

By contrast, other theoretical studies argue that risk-taking behavior decreases with CEO 
age. Prendergast and Stole (1996) present a signaling model that illustrates how, in their attempts to acquire reputations as fast learners, young managers initially exaggerate their own information, leading them to undertake bolder and riskier investments. Over time, however, they become increasingly conservative and unwilling to revise their earlier decisions, as to do so may amount to an acknowledgement of prior mistakes. Moreover, financial incentives might foster risk-taking behavior among younger CEOs. Yim (2013) formalizes the idea that actions leading to permanent increases in compensation are particularly attractive to CEOs with long career horizons, leading them to, for example, pursue acquisition during in early stages of their careers. Finally, age-related psychological biases and physiological limitations may account for differences in risk-taking behavior between younger and older managers. Hambrick and Mason (1984) identify older managers' possible lack of physical and mental stamina, limited ability to grasp new ideas, greater commitment to the firm's status quo, and the desire for financial and career security as potential drivers of their declining propensity for risk-taking. Similarly, Cline and Yore (2016) highlight several potential neurophysiological biases that may become more severe as CEOs age. Taken together, the arguments offered by these studies predict a negative relationship between CEO ages and risk-taking behavior.

Supporting this negative relationship, several empirical studies associate CEO age with riskrelated corporate policy decisions. In particular, Barker and Mueller (2002) find that firms with younger CEOs invest more in research and development (R\&D). Yim (2013) and Zhang et al. (2016) demonstrate that the propensity to make acquisitions decreases with CEO age. However, the studies propose different reasons for this relationship: while Yim (2013) highlights that the accompanying financial benefits appeal to young CEOs because of their long career horizons, Zhang et al. (2016) note the reputational benefits in the UK context. Furthermore, based on plant-level data, Li et al. (2017) show that younger CEOs take on riskier investment decisions. More specifically, they examine several restructuring activities and find that younger CEOs are more inclined to enter new lines of business and exit from existing ones, make bolder expansions and divestments, and preferably use acquisitions, rather than building plants from scratch, to expedite growth. Additionally, using a sample of firms from the oil and gas industry, Croci et al. (2017) show that advancing age increases the likelihood that the CEO will adopt hedging strategies.

The study most closely related to the present study is that of Serfling (2014), who uses a large panel data set and mostly applies fixed-effects regressions to examine the relationship between CEO age and a market-based measure of firm risk - namely, stock return volatility. The main 
finding of Serfling's study is that CEO age is negatively related to firm risk. Furthermore, he negatively associates CEO age with $R \& D$ intensity and operating leverage and positively associates it with corporate diversification. These policies may serve as the channels through which CEOs influence firm risk. Peltomäki et al. (2020) corroborate some of these findings and additionally show that stock return volatility also declines with chief financial officer's (CFO) age.

Notably, most of these studies fail to apply a satisfactory approach to addressing the endogenous nature of such analyses, and so causal interpretations should be considered with caution. I will further discuss this in Section 2.3.1. Nevertheless, since the empirical CEO literature in particular indicates a negative relation between CEO age and risk-taking behavior, I also expect younger (older) CEOs to be more (less) inclined to pursue risky policies, and that their decision to do so will eventually affect their firms' market-based risk level. I state my first hypothesis as follows:

H1: Lower (higher) CEO age leads to higher (lower) firm risk.

If the risk-taking explanation holds, I expect to also find evidence that CEO age influences fundamental risk-related corporate policies. Consequently, I state Hypothesis H2a as follows:

H2a: Lower (higher) CEO age leads to riskier (less risky) corporate policies.

I will test this explanation in Section 2.4.2 in that I analyze whether CEO age influences R\&D expenditures, firm diversification, operating leverage, and financial leverage.

\subsubsection{The market knowledge explanation}

In contrast to the risk-taking explanation, further research casts doubt on the notion of a CEO-specific influence on firms' policies. Fee et al. (2013) fail to identify abnormally high changes in firm policies after exogenous CEO turnovers. ${ }^{5}$ However, they find large changes after endogenous ones and point out that endogeneity issues may also explain the results of many existing studies on the influence of CEOs. This leads me to consider an alternative explanation for the relationship between CEO age and firm risk. In particular, market-based firm risk may be a function of the market's knowledge of the CEOs' abilities rather than a consequence of their fundamental policy decisions. I will call this the market knowledge explanation.

\footnotetext{
${ }^{5}$ Fee et al. (2013) consider an even broader range of CEO turnovers as being exogenous. Their sample of exogenous turnovers comprises cases of deaths, illness, and some natural retirements.
} 
I base this explanation primarily on the stylized Bayesian learning model developed by Pan et al. (2015). With their model, the authors formalize how uncertainty regarding CEO ability — that is, how they will influence future profits - affects the firm's stock return volatility. In the model, the initial uncertainty about the CEO's ability is high, which increases stock return volatility (i.e., firm risk) even beyond the firm's fundamental level. Over time, market participants use news about the firm not only to update their expectations regarding its future profits but also to update their assessment of the CEO. The resulting learning process increases the knowledge about the CEO, and yet the portion of CEO-related uncertainty contained in any news about the firm becomes smaller. Consequently, the firm's stock return volatility will decrease.

Pan et al. (2015) empirically test the model's implications using a sample of CEO turnovers. They choose CEO turnovers because the model implies that market participants are likely to update their assessment of the CEO amid high uncertainty about their ability, which they suspect to be particularly relevant following a CEO turnover. As their model predicts, they find, among other things, that stock return volatility declines over time after a new CEO takes office.

In this light, a similar argument can be made for CEO age. Uncertainty regarding a CEO's ability is likely to be particularly high when they are young, whereas it should decrease with age. A young and inexperienced CEO who has not worked in such a position before is likely to be relatively unknown and, therefore, more difficult for the market to asses than an older and more experienced individual who has several years experience as CEO or in similar positions. In line with this argument, Pan et al. (2015) consider young CEOs as a single group with 'high prior uncertainty'. For these young CEOs' firms, this implies that the lack of knowledge about their CEOs' abilities increases the portion of CEO-related uncertainty contained in any news about the firm, which consequently increases stock return volatility. Notably, this CEO-related effect on volatility is distinct from the fundamental volatility derived from the riskiness of the firm's policies. Only with time will the market learn about the CEO's ability so that CEO-related uncertainty and volatility will decrease. Accordingly, the market knowledge explanation also predicts declining volatility with CEO age, as stated in Hypothesis H1.

I will test this explanation indirectly. Since the present study's setting permits analysis the differential effects that the two treated firms' CEOs have on firm risk, I will analyze circumstances in which I expect the CEO change to lead to considerable changes in the market's knowledge regarding the CEO in office. More specifically, if the CEO's lower age generally leads to higher uncertainty regarding their abilities, this effect should be particularly strong in circumstances 
in which uncertainty regarding their predecessor was low - that is, if their predecessor was well known. For example, switching from an older CEO who had been leading the firm for more than a decade to a relatively unknown younger CEO who had not held such a position before may be expected to increase uncertainty considerably. By contrast, in cases in which the predecessor CEO had been rather unknown himself or herself, maybe because he or she had just recently assumed office, the CEO-related portion of uncertainty cannot be expected to increase much, even if the successor is younger. In this case, it would simply remain at a high level. Consequently, I state Hypothesis H2b as follows:

H2b: Lower (higher) CEO age leads to higher (lower) firm risk, if-and only if - it leads to an actual decrease (increase) in knowledge about the CEO.

To test this hypothesis, I use two proxies for the market's knowledge regarding the predecessor (i.e., the deceased) $\mathrm{CEO}$ and examine whether the effect of $\mathrm{CEO}$ age is stronger in cases in which they can be expected to have been well known. Section 2.4 .3 details these tests.

\subsection{Empirical design}

\subsubsection{The sudden CEO death setting}

Sudden deaths have hitherto predominantly been used in event studies to evaluate the importance of corporate executives for their firms (e.g., Quigley et al., 2017). In this regard, studies identify several person- and firm-related characteristics that determine the market reaction to their publication. ${ }^{6}$ In line with these studies, I use the immediacy of these events to ease endogeneity concerns. Since I do not focus on the short-term stock market reaction, my empirical approach differs: I use sudden CEO deaths to examine the relationship between a specific CEO characteristic, namely CEO age, and firm risk in a DID design.

Analysis of this relationship in this setting provides the following three main advantages over common fixed-effects regressions or regular CEO turnovers. First, sudden deaths lead to a change in the CEO and, thus, a need for a replacement that is clearly induced by exogenous reasons (Fee et al., 2013) and not because of weak performance or an intended change in corporate policies

\footnotetext{
${ }^{6}$ In particular, the literature, for example, shows that the executives' actual role as CEO, president, or chairperson (Worrell et al., 1986; Etebari et al., 1987), personal characteristics such as founder status, ability, or age (Johnson et al., 1985; Hayes and Schaefer, 1999; Jenter et al., 2016), compensation (Nguyen and Nielsen, 2014), corporate governance (Borokhovich et al., 2006; Combs et al., 2007), succession planning (Worrell and Davidson, 1987; Borokhovich et al., 2014), and further firm characteristics such as size or the firms' public status (Worrell and Davidson, 1989; Larson, 1999) influence the market reaction to executives' deaths.
} 
or firm risk. Hence, no clear reasons for CEO turnovers are evident, and if a firm (i.e., the board) had wanted to change their strategic direction or just their CEO, they could have done so independently of the death of the incumbent. Consequently, changes in firm outcomes or policies following such exogenous turnovers can be directly attributed to changes in the CEO and their characteristics. This permits the identification of a causal link running from the (change in the) CEO to firm outcomes and policies, not the other way around. By contrast, highly endogenous forced CEO turnovers, for example, may occur during times in which firms are redefining their strategic direction and thus initiating an array of corporate changes, among which may included the change in the CEO position. Determination of the causal role that CEOs play in such settings is highly challenging, and variants of this logic may explain many of the findings in related studies (Fee et al., 2013).

This may also hold for the existing studies on the relationship between CEO age and firm risk (Serfling, 2014; Peltomäki et al., 2020), because their empirical setting (i.e., fixed effects regressions on a large panel data set) does not allow to conclusively address the endogeneity inherent in such analyses. ${ }^{7}$ Consequently, their results may be biased and can hardly be interpreted causally, although a causal interpretation is suggested to some extent. Their results could, for example, be explained by the firms' simultaneously determination of CEO age and risk. ${ }^{8}$ In that case, causality would run from the firm to $\mathrm{CEO}$ age and not the other way around.

Second, sudden deaths are unexpected and, thus, cannot be foreseen by the market. This is particularly important when analyzing a market-based firm outcome, such as stock return volatility, because it facilitates a clean identification of the effect of the change in the CEO. In a regular turnover circumstances, market participants would have adjusted their expectations at some earlier - likely unknown — point in time, making it difficult to identify the effect.

Third, the use of sudden deaths facilitates for a direct comparison between the treated firms that experienced an exogenously induced change in their CEO and a group of control firms that did not change their CEO during that time. This again permits the identification of the differential effect that two CEOs - the deceased and his or her successor - have on the firm's policies and outcomes using a DID approach.

\footnotetext{
${ }^{7}$ In an attempt to address this issue, Serfling (2014) conducts an instrumental variable approach using the Consumer Price Index (CPI) in the CEOs' birth year as an instrument for CEO age. However, it is hard to argue that the CPI provides a convincing instrument in this context.

${ }^{8}$ Serfling (2014) even shows that high (low) risk firms tend to appoint younger (older) CEOs.
} 
I compile a sample of treated firms to which I match similar control firms that do not change their CEOs around the time of the respective treated firms' events. I then hand-collect both groups' CEO histories for the four years prior to and the four years after the event, which represents this study's timeframe of interest. I retain only the observations for the treated firms' deceased and successor CEOs and for the one corresponding CEO of each control firm. On this basis, I perform DID analyses to examine whether changes in CEO age induced by sudden deaths lead to changes in the treated firms' risk. $^{9}$ I thereby also provide tests that address the endogenous choice of the successor CEO. In the sections that follow, I will explain my empirical approach in greater detail.

To sum up, the setting of the present study provides several advantages over the approaches more commonly applied in examining the influence of CEOs on corporate policies and outcomes. In fact, it better addresses potential endogeneity concerns and thus allows to draw causal inferences regarding the influence of CEOs - in the present study, regarding the influence of CEO age on firm risk.

\subsubsection{Sample of treated firms}

In this section, I describe the derivation of the sample of firms that experienced sudden CEO deaths. I begin with the list of sudden CEO deaths from Quigley et al. (2017), which comprises 239 unexpected deaths of the CEOs of US public companies for the years 1950 to $2009 .{ }^{10}$ To that list, I add another 13 events collected by Merz and Weidemann (2018), who update Quigley et al.'s (2017) data set for the more recent years 2009 to $2017 .{ }^{11}$ This yields an initial sample of 252 events in which the CEO died unexpectedly while in office. From this sample, 48 events are omitted because they cannot be merged with Center for Research in Security Prices (CRSP)/Compustat and a further 28 events are omitted because of missing data necessary for the matching of control firms. The remaining 176 events are then used for the matching procedure, which will be described in Section 2.3.3. Another 36 events drop from the sample because they

\footnotetext{
${ }^{9}$ The fundamental empirical approach of this study is inspired by Shi et al. (2017), who examine the CEOs' acquisition behavior after independent director deaths, and Aktas et al. (2021), who focus on the effect of personal shocks to the CEOs on corporate policy decisions. Both conduct a matching procedure and DID analyses to analyze CEO behavior after shocks that are outside of the CEOs' control.

${ }^{10}$ I thank Timothy Quigley for generously providing his list of unexpected CEO deaths. The difference of one event, compared to the 240 events mentioned in Quigley et al. (2017), stems from a duplicate that the authors have removed after the paper's publication. In accordance with the definition presented in Nguyen and Nielsen (2010), the authors code an unexpected death as one that occurred "instantaneously or within a few hours of an abrupt change in the person's previous clinical state" (Nguyen and Nielsen, 2010, p. 553). The reasons for such deaths, for example, include accidents, murder, or sudden medical issues such as heart attacks or strokes.

${ }^{11}$ I also thank Alexander Merz and J. Felix Weidemann for kindly providing their data.
} 
do not have a minimum of three years before and three years after the event with necessary data available. While the time span of interest in this study covers (up to) four years before and (up to) four years after the sudden deaths, I here relax this requirement somewhat in the interest of retaining more events in the sample. ${ }^{12}$ Additionally, I exclude five events in which the deceased had been in office for less than one year, because these CEOs cannot be assumed to have significantly influenced the firms' policies. Finally, I exclude three events for which I could only confirm that the deceased individuals were the firms' chairmen and not that they were the firms' CEOs at the time of their passing and one event in which the deceased had been assigned to the wrong firm in the original CEO data set. Appendix A.1 provides more detailed information on the derivation of the final sample of events. The final sample used throughout the empirical analyses comprises 131 events of 130 firms that occurred between 1952 and $2014 .{ }^{13}$

For these remaining 'treated' firms, I compile the firms' CEO histories for several years either side of the event. Specifically, I collect the names and ages of the CEOs who had been in office for each firm-year during the four years before and the four years after the year in which the sudden death occurred. When available, I also collect the dates on which the respective CEOs assumed and left office and determine whether they had been among the firm's founders. I begin the data collection with data from ExecuComp, which is available from 1992 onwards and only contains data for a small fraction of the treated sample firms. For the remaining firm-years - that is, for the vast majority of the sample - I hand-collect the CEO data. To that end, I conduct web searches from various sources such as company websites, the Securities and Exchange Commission's (SEC) Electronic Data Gathering, Analysis, and Retrieval (EDGAR) system, LexisNexis, The New York Times, The Wall Street Journal, and Google. Ultimately, I succeeded in obtaining the full CEO history for all treated firms for the entire time span of interest. From the resulting sample, I keep only the observations of the deceased and their permanent successors. More specifically, for the post-event years, I only keep observations of the first successor CEOs that stayed in office for at least two years, that is, I exclude 'interim' CEOs (i.e., that held the position only for a few months or for the following year after the event) and successors of the permanent successor. Further, if the firm had another CEO besides the deceased in the four years prior to the event, I exclude the years of that earlier, non-deceased

\footnotetext{
${ }^{12}$ For the four events that occurred in 1952 , I require only two years before and three years after, because accounting data is only available from 1950 onwards. As noted in Section 2.5.3, the results are robust to excluding these events.

${ }^{13}$ One treated firm experienced two sudden CEO deaths during the sample period that occurred many years from each other (in 1958 and in 2005). The results are robust to excluding these two events.
} 
CEO. Consequently, the data set contains observations pertaining to only two CEOs for each treated firm.

\subsubsection{Matching of control firms}

In general, a DID approach compares a group of treated firms with a group of untreated control firms before and after the treatment. The important identification assumption is that the two groups of firms follow parallel trends with respect to the outcome of interest. This means that the temporal trend in the outcome variable was the same before the treatment and that it would have continued in the absence of it (e.g., Roberts and Whited, 2013). Accordingly, I seek control firms that exhibit similar trends in stock return volatility in the years leading up to the event yet did not change their CEOs around the time of the respective treated firms' events.

To do so, I implement a variant of the nearest neighbor propensity score matching (PSM) method developed by Rosenbaum and Rubin (1983). In particular, I estimate a complementary log-log model instead of the frequently used logit or probit models, as it accounts for the skewed distribution of the dependent variable (Cameron and Trivedi, 2010). Specifically, the dependent variable takes the value of one if the firm experiences a sudden death in the following year, which is the case for the 176 firm-years prior to the sudden death events considered for this estimation. ${ }^{14}$ For all remaining firm-years - that is, for the extensive CRSP/Compustat universe with relevant data - this variable is zero. The matching variables, which serve as the independent variables in the model, should comprise variables that relate to the outcome of interest and to treatment assignment (e.g., Stuart, 2010). Since, a priori, I have no reason to believe that any firm or CEO characteristic increases the likelihood that that firm will experience a sudden CEO death, I apply a set of risk-related firm characteristics as matching variables - that is, measures for firm size, financial leverage, operating performance, R\&D expenditures, growth opportunities, cash holdings, and firm age. I will explain these variables further in Section 2.3.5. Additionally, I include Fama-French 49 industry and year fixed effects. The results of the estimation can be found in Table A.3 in Appendix A.2.

On the basis of this estimation, I then predict the propensity score, which represents the estimated likelihood of a firm experiencing a sudden CEO death in the following fiscal year, given the set of matching variables. I then use this propensity score to find one control firm for each of the

\footnotetext{
${ }^{14}$ To improve the estimation's efficiency, I decided to keep as many events as possible, although some of them cannot be conserved for the main analyses. The reason that the numbers of considered events differ is that the estimation here only requires data on the matching variables in the year prior to the event, whereas in the main analyses more years with relevant data are needed.
} 
treated firms. While the pool of potential control firms (i.e., all non-treated firms with relevant data covered by CRSP/Compustat) is vast, I have to overcome one important challenge: that is, I require adequate control firms that did not change their CEOs around the time of the treated firms' events without having the necessary CEO data for the vast majority of potential control firms. I address this issue in the following way: using the predicted propensity score, I initially match several potential control firms, without replacement, to each of the treated firms in the year prior to the event. That is, I begin by assigning the first best match to each of the treated firms, followed by the second best, and so on. In this process, I ensure that I only match (non-)financial firms - as indicated by the Fama-French 49 industries 45-48 - with (non-)financial firms. Next, I hand-collect the data on the firms' CEO histories for each first best match using the same approach as that adopted for the treated firms (outlined in Section 2.3.2). If the data collection reveals that the $\mathrm{CEO}$ of the first best match changes in the two years prior and the three years after the event, I go on to the second best match, and so on. ${ }^{15}$ Ultimately, for each treated firm, I choose the best matched firm (i.e., with the smallest difference in the propensity score) that had not undergone a CEO turnover around the time of the event. In more than 90 percent of the cases, I identify such a control firm among the top three matched firms, and only in one case am obliged to resort to the sixth match. ${ }^{16}$ Having compiled the full CEO history for the chosen control firms for the time span of interest, I exclude a few firm-year observations in which the control firms had experienced a CEO turnover outside of the two years prior or three years after the event. Consequently, the final sample contains only one CEO for each control firm.

Notably, the inaccessibility of the CEO data prior to performing the matching procedure prevents me from testing several different matching approaches. At first sight, this may appear as a constraint. However, this also implies that before I could perform my analyses on the matched sample, I first had to decide on the overall matching approach, execute the matching, and extensively collect data on the CEOs. This again should dispel any doubts about "post hoc model selection" (Shipman et al., 2017, p. 217) and thus should strengthen rather than weaken the validity of my results.

\footnotetext{
${ }^{15}$ Although the main analyses focus on up to four years before and after the event, I only require this somewhat smaller time span without a CEO turnover to obtain better matches. If then, for example, the CEO of a control firm changed in the fourth year after the event, I exclude this one firm-year observation. Besides, the results are robust to choosing control firms that do not change their CEO within three years before and after the event.

${ }^{16}$ Table A.4 in Appendix A.2 provides an overview of the control firm numbers taken.
} 


\subsubsection{Difference-in-differences approach}

Based on the above-described matched sample of treated and control firms, I perform DID analyses to examine the influence of CEO age on firm risk. In particular, I analyze whether changes in CEO age induced by sudden deaths lead to changes in firm risk for the treated firms. Since the final sample only contains observations of two CEOs for each treated firm and of one CEO for each control firm, they reveal the differential effect that the two different treated firms' CEOs have on firm risk. Throughout the analyses, I exclude the event year because the study's focus is not on the short-term uncertainty that occurs in the aftermath of the unexpected death, but rather on the fundamental, longer-term effects of the scenario wherein two different individuals are in charge.

To determine the effect of CEO age on firm risk in this setting, I adopt two DID approaches, each of which addresses different aspects of the effect. Each approach has the same general idea - that is, to condition the treatment effect on the change in CEO age that accompanies the exogenously induced CEO turnover. The first approach addresses a remaining endogeneity issue and should thus be the optimal approach to reveal the causal effect of CEO age on firm risk. Specifically, when conditioning the DID effect on the change in CEO age, selection of a successor, which, of course, also influences the change in age, remains an endogenous choice on the firm's part. This may result in a simultaneity problem (as described in Section 2.3.1), because the firm may simultaneously determine CEO age and a changes in future firm policies. From a theoretical perspective, these concerns can be alleviated insofar that if the firm had wanted to implement changes, including the CEO, it could have done so independently of their sudden death.

Nevertheless, I also address this concern empirically by analyzing the treatment effect for a specific group of firms that virtually had no choice but lower CEO age-namely, firms in which the deceased had reached or exceeded the typical retirement age at the time of their deaths. For those firms, not only was the cause of the CEO turnover exogenous but also the need to lower CEO age. Hence, the question of whether or not the deceased had reached retirement age serves as a (noisy) proxy for the reduction in the firms' CEO age. I define a retirement-age CEO as one who had reached the age of 65 at the time of their death. I choose 65 as the threshold because this represents the typical retirement age for CEOs in the US (Jenter and Lewellen, 2015). In total, the sample includes 38 events of retirement-age CEOs and 93 events in which the CEO had not yet reached this age. Table 2.1 provides an overview of the two groups. 
Table 2.1: Overview of the retirement age groups

\begin{tabular}{lccccc}
\hline Groups & Min & Max & Mean & Median & Events \\
\hline All Events & 39 & 87 & 60.7 & 60 & 131 \\
\hline Retirement Age CEO & 65 & 87 & 70.9 & 68.5 & 38 \\
Non-Retirement Age CEO & 39 & 64 & 56.6 & 58 & 93 \\
\hline
\end{tabular}

This table provides an overview of the distribution of the age of the deceased CEOs across all events as well as for the two (non-)retirement age groups. It also displays the number of events that fall into each group.

Methodically, I estimate a typical DID model but split the treatment effect using indicators for treated firms with (non-)retirement age CEOs. The respective equation is as follows:

$$
\begin{aligned}
\text { Volatility }_{i, t}= & \alpha+\beta_{1} \text { Treated }_{i} \times \text { Post }_{t} \times \text { Non-Retirement Age CEO } \\
& +\beta_{2} \text { Treated }_{i} \times \text { Post }_{t} \times \text { Retirement Age CEO }_{i} \\
& +\gamma \text { Controls }_{i, t}+\lambda_{i}+\phi_{t}+\epsilon_{i, t}
\end{aligned}
$$

in which Volatility $_{i, t}$ is either the overall or idiosyncratic stock return volatility for firm $i$ in fiscal year $t$, respectively. Treated $i$ is a dummy variable that equals one for firms that experienced sudden CEO deaths and zero for the control firms. Post $t_{t}$ is a dummy variable equal to one for the four years after and zero for the four years prior to the event. Retirement Age CEO is a dummy variable equal to one for the treated firms in which the deceased were 65 or older at the time of their passing and zero otherwise. Non-Retirement Age CEO is a dummy variable equal to one for the treated firms in which the deceased were younger than 65 and zero otherwise. The vector Controls C $_{i, t}$ comprises several firm characteristics relating to firm risk - that is, firm size, financial leverage, operating performance, R\&D expenditures, growth opportunities, cash holdings, and firm age - which will be further explained in Section 2.3.5. Although I also match on these variables, I still include them in the models to control for any remaining observable differences between the two groups of firms that might drive the effect on firm risk. I also include firm fixed effects $\left(\lambda_{i}\right)$ to control for unobserved firm-level heterogeneity, addressing a potential omitted variable bias, and year fixed effects $\left(\phi_{t}\right)$ to account for the market-wide specifics of a particular year. The firm and year fixed effects subsume the effects of the single Treated $_{i}$ and Post $_{t}$ indicators, respectively. $\epsilon_{i, t}$ is the error term. Throughout the analyses, I consistently cluster standard errors at the firm level.

Generally speaking, $\beta_{1}$ and $\beta_{2}$ both capture the difference in volatility between treated and control firms from before to after the exogenous change of CEO - that is, the DID effect-for 
the respective group of treated firms. I am primarily interested in the coefficient $\beta_{2}$, because it represents the change in volatility for the group that had to decrease CEO age. Since the expectation is that lower CEO age increases firm risk, I expect $\beta_{2}$ to be positive. By contrast, I expect $\beta_{1}$ to be statistically indistinguishable from zero.

The second approach is set up to provide a more detailed picture of the age difference necessary for the occurrence of the effect and its economic magnitude. For this purpose, I calculate the change in CEO age induced by sudden death as the difference between the age of the deceased at the time of their death and the successor's age upon taking office. Based on the terciles of the empirical distribution of this change, I define three dummy variables indicating different 'age change groups'. Accordingly, the dummy variable Stable/Increase takes the value of one for treated firms with a change in CEO age of -3 to 20 and zero otherwise, Moderate Decrease is a dummy variable equal to one for treated firms with a change in CEO age of -12 to -4 and zero otherwise, and Large Decrease is a dummy variable equal to one for treated firms with a change in CEO age of -35 to -13 and zero otherwise. ${ }^{17}$ Table 2.2 provides an overview of the three age change groups.

Table 2.2: Overview of the age change groups

\begin{tabular}{lccccc}
\hline Groups & Min & Max & Mean & Median & Events \\
\hline All Events & -35 & 20 & -9.1 & -9 & 131 \\
\hline Stable/Increase & -3 & 20 & 2.0 & 1 & 40 \\
Moderate Decrease & -12 & -4 & -8.2 & -9 & 47 \\
Large Decrease & -35 & -13 & -20.1 & -18 & 44 \\
\hline
\end{tabular}

This table provides an overview of the distribution of the change in CEO age across all events as well as for the three age change groups. The change in CEO age is calculated as the difference between the age of the deceased at the time of his or her passing and the successor's age at the time of taking office. It also displays the number of events that fall into each group.

I then take Equation (2.1) and replace the indicators for the (non-)retirement age groups with the indicators for the age change groups. The updated equation looks as follows:

\footnotetext{
${ }^{17}$ In this definition I sort the tercile thresholds of -13 and -4 into the respective lower categories. However, the results are basically unchanged when I sort the threshold events into the respective higher categories. In Section 2.5.2, I check the robustness of the results to alternative age change groupings.
} 


$$
\begin{aligned}
\text { Volatility }_{i, t}= & \alpha+\beta_{3} \text { Treated }_{i} \times \text { Post }_{t} \times \text { Stable }_{\text {Increase }} \\
& +\beta_{4} \text { Treated }_{i} \times \text { Post }_{t} \times \text { Moderate Decrease }_{i} \\
& +\beta_{5} \text { Treated }_{i} \times \text { Post }_{t} \times \text { Large Decrease }_{i} \\
& +\gamma \text { Control }_{i, t}+\lambda_{i}+\phi_{t}+\epsilon_{i, t}
\end{aligned}
$$

in which Stable/Increase ${ }_{i}$, Moderate Decrease $_{i}$, and Large Decrease $_{i}$ are dummy variables indicating the respective groups defined above. The remaining variables are the same as in Equation (2.1). I am primarily interested in the coefficient $\beta_{5}$, which captures the DID effect for the treated firms that lowered CEO age the most. In line with the previously formulated expectations, I expect $\beta_{5}$ to be positive. Whether or not a moderate decrease in CEO age already leads to a change in firm risk, which would be indicated by $\beta_{4}$, remains an empirical question. Further, I expect a non-significant or a negative coefficient estimate for the stable/increase group of firms, as indicated by $\beta_{3}$.

To sum up, while the approach from Equation (2.1) should allow a causal interpretation of the effect of CEO age on firm risk, that from Equation (2.2) will reveal a more detailed picture of the occurrence and the economic magnitude of the effect. Throughout the analyses, I always perform both.

\subsubsection{Data and main variables}

I merge the CEO data set with stock return data from the CRSP, used to calculate the volatility measures, and Compustat, from which I obtain accounting and financial data. The latter are available from 1950 onward setting the lower bound for the sample period.

I define the following two measures of firm risk: for each firm-year, I calculate the overall stock return volatility (Volatility) as the annualized standard deviation of daily stock returns and idiosyncratic volatility (Idio $\mathrm{Vol}$ ) as the annualized standard deviation of daily residuals, obtained from Fama-French three-factor model estimations. ${ }^{18}$ These measures serve as the main dependent variables in the empirical analyses.

Additionally, in the PSM as well as throughout the empirical analyses, I include several further explanatory variables that have been shown to be related to firm risk. In particular, I consider firm

\footnotetext{
${ }^{18} \mathrm{I}$ collect data on the risk-free rate as well as on the risk factors from Kenneth French's data library (available at http://mba.tuck.dartmouth.edu/pages/faculty/ken.french/data_library.html).
} 
size as measured by Ln(Total Assets), financial leverage (Book Leverage), operating performance $(R O A)$, research and development $(\mathrm{R} \& \mathrm{D})$ expenditures $(R \mathcal{E} D / A s s e t s)$, growth opportunities (CAPEX/Sales), cash holdings (Cash/Assets), and Firm Age. The variables' definitions can be found in Table A.2 in Appendix A.2. Notably, this study's long sample period-dating back to 1950 - and the already-small sample limits the possibility of controlling for aspects of managerial compensation (i.e., delta and vega), which have also been shown to be related to firm risk (Coles et al., 2006). ${ }^{19}$ However, the inclusion of firm fixed effects throughout the multivariate analyses should, at least, account for the time-invariant firm-specific component of such aspects.

To account for the possibility of extreme firm-years driving my results, I exclude the most extreme observations for both treated and control firms before I beginning the empirical analyses. That is, I remove nine firm-year observations for each group in which the stock return volatility was above the top one percentile among those firms.

\subsubsection{Descriptive statistics}

The resulting final sample comprises 1,929 observations pertaining to the 130 treated and 131 control firms. Table 2.3 illustrates the descriptive statistics for both the volatility measures and the firm controls.

Table 2.3: Summary statistics

\begin{tabular}{lcccccccc}
\hline & Obs. & Mean & SD & Min. & 25th Pct. & Median & 75th Pct. & Max. \\
\hline Volatility Measures & & & & & & & & \\
Volatility (\%) & 1929 & 39.2733 & 20.5097 & 7.0265 & 24.7215 & 33.1917 & 49.0053 & 130.2079 \\
IdioVol (\%) & 1929 & 35.8538 & 19.8001 & 6.9913 & 21.9360 & 30.0666 & 44.0427 & 129.4325 \\
\hline Firm Controls & & & & & & & & \\
Total Assets & 1929 & 2052.4788 & 7180.6609 & 1.9050 & 76.7000 & 247.6000 & 1035.6090 & 80216.8125 \\
Book Leverage (\%) & 1929 & 24.9196 & 19.2166 & 0.0000 & 9.7134 & 22.7588 & 35.9807 & 90.9133 \\
ROA (\%) & 1929 & 4.8009 & 9.5227 & -123.2605 & 2.3368 & 5.4125 & 8.6688 & 26.4265 \\
R\&D/Assets (\%) & 1929 & 1.4564 & 3.4603 & 0.0000 & 0.0000 & 0.0000 & 1.4215 & 47.7426 \\
CAPEX/Sales (\%) & 1929 & 7.6410 & 15.4098 & 0.0000 & 1.7369 & 3.5436 & 7.8285 & 237.9030 \\
Cash/Assets (\%) & 1929 & 12.3194 & 14.1593 & 0.0370 & 3.0517 & 7.0173 & 16.0303 & 85.5045 \\
Firm Age & 1929 & 16.8590 & 11.4269 & 1.0000 & 8.0000 & 14.0000 & 23.0000 & 62.0000 \\
\hline
\end{tabular}

This table presents summary statistics for the matched sample of treated and control firm. The sample consists of 130 treated firms with 131 sudden CEO deaths that occurred between 1952 and 2014, and 131 control firms. For each firm, the sample contains data for (up to) four years before and (up to) four years after the respective treated firm's event. Data for the construction of the variables is from the Center for Research in Security Prices (CRSP) and from Compustat. All variable definitions can be found in Table A.2 in Appendix A.2.

\footnotetext{
${ }^{19}$ Data on delta and vega are only available from 1992 onward and only for a subsample of the firms considered in this study, so that inclusion of these variables would reduce the sample significantly.
} 
In addition, Table 2.4 compares the means of the main variables between the treated and control firms in the years prior to the event. This provides an initial indication of the quality of the matching and reveals potential remaining differences in the observable characteristics between the two groups of firms.

Table 2.4: Treated vs. matched control firms before the event

\begin{tabular}{lcccccc}
\hline & $\begin{array}{c}\text { Obs. } \\
\text { Treated }\end{array}$ & $\begin{array}{c}\text { Obs. } \\
\text { Control }\end{array}$ & $\begin{array}{c}\text { Mean } \\
\text { Treated }\end{array}$ & $\begin{array}{c}\text { Mean } \\
\text { Control }\end{array}$ & Difference & $p$-Value \\
\hline Volatility Measures & & & & & & \\
Volatility (\%) & 469 & 475 & 39.5197 & 39.5758 & -0.0561 & 0.9667 \\
IdioVol (\%) & 469 & 475 & 36.2605 & 36.1354 & 0.1251 & 0.9232 \\
\hline Firm Controls & & & & & & \\
Total Assets & 469 & 475 & 1935.6011 & 1637.9984 & 297.6026 & 0.5144 \\
Book Leverage (\%) & 469 & 475 & 24.0740 & 26.0208 & -1.9468 & 0.1267 \\
ROA (\%) & 469 & 475 & 4.7291 & 5.1913 & -0.4622 & 0.4744 \\
R\&D/Assets (\%) & 469 & 475 & 1.2175 & 1.5903 & -0.3728 & 0.0872 \\
CAPEX/Sales (\%) & 469 & 475 & 6.5215 & 7.9150 & -1.3935 & 0.0755 \\
Cash/Assets (\%) & 469 & 475 & 13.4970 & 13.0847 & 0.4123 & 0.6834 \\
Firm Age & 469 & 475 & 14.1620 & 14.8063 & -0.6443 & 0.3713 \\
\hline
\end{tabular}

This table compares the means of the volatility measures as well as for the firm controls between treated and control firms in the years before the sudden deaths. $p$-values are based on t-tests of differences in means. All variable definitions can be found in Table A.2 in Appendix A.2.

With two exceptions, the results largely show that treated and control firms do not differ significantly in terms of the firm risk-related characteristics considered in this study. The two exceptions are the ratios of R\&D to assets and capital expenditures to sales, which are both slightly lower for the treated firms on the ten percent significance level. Aside from these, treated and control firms exhibit similar levels of (idiosyncratic) volatility prior to the event. These insights support the idea that the matching procedure indeed produced two similar groups of firms, as is necessary when performing DID analyses. Additionally, in Section 2.5.1, I provide evidence that the crucial parallel trends assumption holds for this sample. However, to account for any remaining differences in observable firm characteristics that might drive the treatment effect on volatility, I include all of these risk-related firm characteristics as controls throughout the empirical analyses. Furthermore, I include firm and year fixed effects to account for unobserved heterogeneity. 


\subsection{Main analyses}

\subsubsection{CEO age and firm risk}

I begin the empirical analysis by examining the relationship between $\mathrm{CEO}$ age and firm risk. To do so, I first estimate Equation (2.1), in which retirement age serves as a (noisy) proxy for decreasing CEO age. The expectation is that (idiosyncratic) volatility increased significantly for the group of firms that experienced sudden deaths of retirement-age CEOs, whereas the non-retirement age group should exhibit no change in volatility. For both volatility measures, I consistently estimate two versions of the model: one that includes the additional control variables and one that does not. Table 2.5 presents the results.

Table 2.5: Effect on volatility by (non-)retirement age CEO groups

\begin{tabular}{|c|c|c|c|c|}
\hline & \multicolumn{2}{|c|}{ Overall Volatility } & \multicolumn{2}{|c|}{ Idiosyncratic Volatility } \\
\hline & $\begin{array}{c}(1) \\
\text { Volatility }\end{array}$ & $\begin{array}{c}(2) \\
\text { Volatility }\end{array}$ & $\begin{array}{c}(3) \\
\text { IdioVol }\end{array}$ & $\begin{array}{c}(4) \\
\text { IdioVol }\end{array}$ \\
\hline Treated $\times$ Post $\times$ Non-Retirement Age CEO & $\begin{array}{l}-0.9291 \\
(0.4879)\end{array}$ & $\begin{array}{l}-1.0066 \\
(0.4300)\end{array}$ & $\begin{array}{l}-0.7262 \\
(0.5724)\end{array}$ & $\begin{array}{l}-0.8561 \\
(0.4768)\end{array}$ \\
\hline Treated $\times$ Post $\times$ Retirement Age CEO & $\begin{array}{l}3.9239^{*} \\
(0.0544)\end{array}$ & $\begin{array}{l}4.3890^{* *} \\
(0.0194)\end{array}$ & $\begin{array}{l}3.7117^{*} \\
(0.0747)\end{array}$ & $\begin{array}{l}4.0787^{* *} \\
(0.0268)\end{array}$ \\
\hline Ln(Total Assets) & & $\begin{array}{c}-3.8002^{*} \\
(0.0585)\end{array}$ & & $\begin{array}{c}-4.6912^{* *} \\
(0.0192)\end{array}$ \\
\hline Book Leverage & & $\begin{array}{c}0.0907 \\
(0.1367)\end{array}$ & & $\begin{array}{c}0.0874 \\
(0.1411)\end{array}$ \\
\hline ROA & & $\begin{array}{l}-0.1725 \\
(0.1030)\end{array}$ & & $\begin{array}{l}-0.1721 \\
(0.1122)\end{array}$ \\
\hline $\mathrm{R} \& \mathrm{D} /$ Assets & & $\begin{array}{c}0.0142 \\
(0.9643)\end{array}$ & & $\begin{array}{c}0.0292 \\
(0.9227)\end{array}$ \\
\hline CAPEX/Sales & & $\begin{array}{l}-0.0470 \\
(0.3485)\end{array}$ & & $\begin{array}{l}-0.0481 \\
(0.3613)\end{array}$ \\
\hline Cash/Assets & & $\begin{array}{l}-0.0197 \\
(0.8073)\end{array}$ & & $\begin{array}{l}-0.0385 \\
(0.6529)\end{array}$ \\
\hline Firm Age & & $\begin{array}{c}0.0096 \\
(0.9630)\end{array}$ & & $\begin{array}{c}0.1132 \\
(0.5622)\end{array}$ \\
\hline Year Fixed Effects & Yes & Yes & Yes & Yes \\
\hline Firm Fixed Effects & Yes & Yes & Yes & Yes \\
\hline Number of Firms & 261 & 261 & 261 & 261 \\
\hline Number of Observations & 1,929 & 1,929 & 1,929 & 1,929 \\
\hline Adj. R-Squared & 0.2771 & 0.2980 & 0.2143 & 0.2445 \\
\hline
\end{tabular}

This table presents DID analyses for the effect of CEO age on firm risk. In the regressions, the treatment effect is split for firms with sudden deaths of retirement age and non-retirement age CEOs. The dependent variables are Volatility or Idio Vol, respectively. Treated is a dummy variable equal to one for firms that experienced a sudden death and zero for the control firms. Post is a dummy variable equal to one for the four years after and zero for the four years prior to the event. Retirement Age CEO is a dummy variable equal to one for the treated firms in which the deceased were 65 or older at the time of their passing and zero otherwise. Non-Retirement Age CEO is a dummy variable equal to one for the treated firms in which the deceased were younger than 65 and zero otherwise. Definitions for the remaining variables can be found in Table A.2 in Appendix A.2. All models include firm and year fixed effects, as well as a constant term. The $p$-values are based on standard errors clustered at the firm-level and are reported in parentheses, with $*{ }^{* *}$, and $* * *$ indicating significance levels of $10 \%, 5 \%$, and $1 \%$, respectively. 
As expected, the results demonstrate that the firms that experienced sudden deaths of retirementage CEOs - that is, firms that had to decrease CEO age - experienced a significant increase in volatility, whereas those with younger deceased CEOs did not. Throughout all four models - for both overall and idiosyncratic volatility as well as with and without the additional controls - the coefficient estimates for the non-retirement age group are statistically indistinguishable from zero, whereas those for the retirement age group are positive and statistically significant at the five and ten percent levels. These results support the notion of a negative influence of CEO age on firm risk. Crucially, these results allow for a causal interpretation of the effect, because in this case, even the selection of a younger successor can be regarded as exogenous.

It is also worth mentioning that retirement age only serves as a (noisy) proxy for the age reduction. Research has shown that in rare cases, firms hire CEOs that have passed the typical retirement age (Wang and Yin, 2020). If some of the firms that I include in the retirement age group had chosen such retirement-age successors, the effect of the decrease in age would be diluted and would thus hinder my attempt to yield significant results here. The fact that a significant effect is still identified should further support its existence. Furthermore, while this analysis provides clear advantages in terms of causal interpretation, it is more difficult to draw inferences regarding the effect's economic magnitude.

To obtain a more detailed picture of the effect's occurrence and its economic magnitude, I next estimate Equation (2.2), analyzing the treatment effect by the three previously defined age change groups. The expectation here is that volatility increased significantly for the group of firms that experienced a large decrease in CEO age, whereas the group that maintained CEO age stability or even increased CEO age should exhibit no change in volatility or even a decrease. Table 2.6 illustrates the results.

The results indicate that only the group of firms with a large decrease in CEO age experienced an increase in volatility following a change in the CEO. Throughout all four models, the coefficient estimates on the interaction terms for the large decrease group are negative and (highly) statistically significant at the one or five percent levels. This corroborates the results from the previous analysis regarding the negative effect of $\mathrm{CEO}$ age on firm risk. Moreover, these results demonstrate that an increase in volatility is economically meaningful. Since volatility is a percental measure, the coefficient estimate of the DID interaction term for the large decrease group in Model (2), for example, indicates that, on average, stock return volatility increased by 5.0770 percentage points for these firms following the CEOs' sudden deaths compared the control 
Table 2.6: Effect on volatility by age change groups

\begin{tabular}{|c|c|c|c|c|}
\hline & \multicolumn{2}{|c|}{ Overall Volatility } & \multicolumn{2}{|c|}{ Idiosyncratic Volatility } \\
\hline & $\begin{array}{c}(1) \\
\text { Volatility }\end{array}$ & $\begin{array}{c}(2) \\
\text { Volatility }\end{array}$ & $\begin{array}{c}(3) \\
\text { IdioVol }\end{array}$ & $\begin{array}{c}(4) \\
\text { IdioVol }\end{array}$ \\
\hline Treated $\times$ Post $\times$ Stable/Increase & $\begin{array}{l}-1.4883 \\
(0.5302)\end{array}$ & $\begin{array}{l}-1.4724 \\
(0.5102)\end{array}$ & $\begin{array}{l}-0.8360 \\
(0.7178)\end{array}$ & $\begin{array}{l}-0.9188 \\
(0.6686)\end{array}$ \\
\hline Treated $\times$ Post $\times$ Moderate Decrease & $\begin{array}{l}-1.5078 \\
(0.3093)\end{array}$ & $\begin{array}{l}-1.7430 \\
(0.2384)\end{array}$ & $\begin{array}{l}-1.2878 \\
(0.3644)\end{array}$ & $\begin{array}{l}-1.5752 \\
(0.2684)\end{array}$ \\
\hline Treated $\times$ Post $\times$ Large Decrease & $\begin{array}{l}4.6495^{* *} \\
(0.0168)\end{array}$ & $\begin{array}{c}5.0770^{* * *} \\
(0.0060)\end{array}$ & $\begin{array}{l}4.0505^{* *} \\
(0.0368)\end{array}$ & $\begin{array}{l}4.4303^{* *} \\
(0.0135)\end{array}$ \\
\hline Ln(Total Assets) & & $\begin{array}{r}-3.7287^{*} \\
(0.0598)\end{array}$ & & $\begin{array}{c}-4.6070^{* *} \\
(0.0200)\end{array}$ \\
\hline Book Leverage & & $\begin{array}{c}0.0891 \\
(0.1417)\end{array}$ & & $\begin{array}{l}0.0855 \\
(0.1495)\end{array}$ \\
\hline $\mathrm{ROA}$ & & $\begin{array}{l}-0.1754^{*} \\
(0.0922)\end{array}$ & & $\begin{array}{l}-0.1749 \\
(0.1018)\end{array}$ \\
\hline R\&D/Assets & & $\begin{array}{c}0.0302 \\
(0.9239)\end{array}$ & & $\begin{array}{c}0.0431 \\
(0.8855)\end{array}$ \\
\hline CAPEX/Sales & & $\begin{array}{l}-0.0471 \\
(0.3444)\end{array}$ & & $\begin{array}{l}-0.0482 \\
(0.3574)\end{array}$ \\
\hline Cash/Assets & & $\begin{array}{l}-0.0394 \\
(0.6260)\end{array}$ & & $\begin{array}{l}-0.0573 \\
(0.5064)\end{array}$ \\
\hline Firm Age & & $\begin{array}{l}-0.0334 \\
(0.8647)\end{array}$ & & $\begin{array}{c}0.0730 \\
(0.6975)\end{array}$ \\
\hline Year Fixed Effects & Yes & Yes & Yes & Yes \\
\hline Firm Fixed Effects & Yes & Yes & Yes & Yes \\
\hline Number of Firms & 261 & 261 & 261 & 261 \\
\hline Number of Observations & 1,929 & 1,929 & 1,929 & 1,929 \\
\hline Adj. R-Squared & 0.2801 & 0.3016 & 0.2161 & 0.2470 \\
\hline
\end{tabular}

This table presents DID analyses for the effect of CEO age on firm risk. In the regressions, the treatment effect is split for three age change groups. The dependent variables are Volatility or IdioVol, respectively. Treated is a dummy variable equal to one for firms that experienced a sudden death and zero for the control firms. Post is a dummy variable equal to one for the four years after and zero for the four years prior to the event. Stable/Increase, Moderate Decrease, and Large Decrease are dummy variables equal to one for treated firms with a change in CEO age of -3 to $20,-12$ to -4 , and -35 to -13 , respectively, and zero otherwise. Definitions for the remaining variables can be found in Table A.2 in Appendix A.2. All models include firm and year fixed effects, as well as a constant term. The $p$-values are based on standard errors clustered at the firm-level and are reported in parentheses, with $*, * *$, and $* * *$ indicating significance levels of $10 \%, 5 \%$, and $1 \%$, respectively. 
group. Considering the treated firms' mean volatility of 39.5197 percent in the pre-event period, this implies an increase of 12.8 percent. While the coefficient estimates for idiosyncratic volatility are slightly smaller, the percental change is almost the same (i.e., 12.2 percent based on Model (4)). ${ }^{20}$ Contrarily, the coefficient estimates indicating the treatment effect for the remaining two groups of firms are statistically indistinguishable from zero. This provides another interesting insight: an increase in volatility only occurs if the succeeding $\mathrm{CEO}$ is much younger than their predecessor.

In sum, the results presented in this section demonstrate that large decreases in CEO age lead to increased stock return volatility. This is in line with the notion formulated in Hypothesis H1 that CEO age negatively influences firm risk. Furthermore, they substantiate the firm risk results reported by Serfling (2014) and Peltomäki et al. (2020) in that they offer greater allowance for a causal interpretation. However, it remains unclear from where the increased firm risk derives, as the negative relationship is in line with both explanations described in Section 2.2. Below, I provide tests for both explanations.

\subsubsection{CEO age and risk-taking}

The relevant existing studies invoke to the risk-taking explanation to justify the relationship between CEO age and firm risk. In support of this, Serfling (2014) demonstrates that CEO age is negatively related to $\mathrm{R} \& \mathrm{D}$ intensity as well as operating leverage and positively related to corporate diversification, which may serve as the channels through which the CEOs influence firm risk. ${ }^{21}$ To determine whether the risk-taking explanation also holds when analyzed in the present study's setting, I test whether the changes in CEO age induced by sudden deaths lead to changes in risk-related corporate policies. I focus on the same investment and financial policies that Serfling (2014) examines-investments in $R \& D$, firm diversification, operating leverage, and financial leverage — while using the same proxies to measure these concepts. ${ }^{22}$

First, since R\&D expenditures represent one form of investment whose future benefits are particularly uncertain, they serve as an important channel through which CEOs can influence

\footnotetext{
${ }^{20}$ Here, the coefficient estimate of 4.4303 from Model (4) is compared to the mean idiosyncratic volatility of the treated firms in the pre-event period of 36.2605 percent.

${ }^{21}$ Peltomäki et al. (2020) confirm the result for R\&D intensity, but they do not find statistically significant results for financial leverage, cash holdings, and cash flow volatility.

${ }^{22}$ Unlike Serfling (2014), I do not analyze diversifying acquisitions, because of the limited data availability in the Securities Data Corporation (SDC) database for the present study's long sample period. Furthermore, since such an analysis would require the exclusive inclusion of firms that actually conduct acquisitions, this would considerably diminish the quality of the matching as well as the overall sample size of this study.
} 
the firm's riskiness (e.g., Kothari et al., 2002; Coles et al., 2006; Cassell et al., 2012; Kini and Williams, 2012; Ferris et al., 2017). I measure R\&D intensity as the ratio of R\&D expenditures to the book value of assets $(R \mathscr{E} D /$ Assets $) .{ }^{23}$ Since $\mathrm{R} \& \mathrm{D}$ expenditures represent risky investments, the risk-taking explanation predicts that (large) decreases in CEO age will be accompanied by comparably higher values in $R \mathscr{E} D /$ Assets.

Second, CEOs can influence firm risk through corporate diversification - that is, the extent to which they diversify the business segments in which their firms operate (e.g., Amihud and Lev, 1981; Coles et al., 2006; Ferris et al., 2017). I use two measures of corporate diversification, both based on the Compustat Historical Segments database (available since 1976). The first, Ln(Business Segments), is the natural logarithm of the number of business segments in which the firm operates. The second, Segment HHI, represents the Herfindahl-Hirschman Index of the sales of the firm's business segments and is calculated as the sum of the squared ratios of the individual business segments' sales to the firm's total sales. Thus, this variable can take values from zero to one, with higher values indicating less diversification. Just as Serfling (2014), I assume the firm's number of business segments to be one if the firm is not contained in the database in a given year. Since diversification reduces firm risk, the risk-taking explanation predicts that (large) decreases in CEO age should be followed by comparably lower values in Ln(Business Segments) and higher values in Segment HHI.

Third, actions that alter the firm's operating leverage offer another means by which CEOs can impact firm riskiness. Simply put, operating leverage refers to the ratio of fixed to variable operating costs, with high values indicating lower operating flexibility and, thus, higher risk (Lev, 1974; Mandelker and Rhee, 1984; Chen et al., 2011). I measure operating leverage in accordance with Serfling's (2014), which is based on those of Mandelker and Rhee (1984) and Chen et al. (2011) as the elasticity of the firm's operating income with respect to its sales. More specifically, it represents the percentage change in the firm's operating income for a percentage change in sales. To calculate the measure, I use Compustat quarterly data (available since 1962) and estimate the following equation for each firm $i$ in each year $t$ during the three-year window from $t$ to $t+2$ :

$$
O I A D P_{q}=\alpha+\pi S A L E_{q}+\epsilon_{q}
$$

\footnotetext{
${ }^{23}$ In line with the literature, I set missing values of R\&D expenditures to zero (e.g., Coles et al., 2006; Kini and Williams, 2012; Serfling, 2014).
} 
in which $O I A D P_{q}$ is the firm's operating income after depreciation in quarter $q$ and $S A L E_{q}$ represents the firm's quarterly sales. I then take the estimated coefficient $\pi_{i, t}$ for the respective firm $i$ in fiscal year $t$ to calculate Operating Leverage as $\pi_{i, t}\left(\overline{S A L E_{i, t}} / \overline{O I A D P_{i, t}}\right)$, where $\overline{S A L E_{i, t}}$ and $\overline{O I A D P_{i, t}}$ are the average values from year $t$ to $t+2$ of the respective variables for firm $i$. I only calculate the variable if at least eight quarters of non-missing data are available. Additionally, to avoid attributing a successor CEO's investment behavior to their predecessor, I adjust the variable in cases in which the CEO had changed within the three-year estimation period. Specifically, I replace values in which the estimation period include a CEO turnover with the last value that could be estimated without including a CEO turnover. ${ }^{24}$ This should better reflect the respective incumbent CEO's investment behavior. Since higher operating leverage is associated with higher firm risk, the risk-taking explanation predicts that (large) decreases in CEO age should be followed by comparably higher values in Operating Leverage.

Finally, choosing or altering financial leverage is another channel through which CEOs can affect firm risk (Coles et al., 2006; Lewellen, 2006; Kini and Williams, 2012). I use Book Leverage, calculated as the sum of long-term debt and current liabilities divided by the book value of assets, to measure financial leverage. ${ }^{25}$ Since higher financial leverage is associated with higher firm risk, the risk-taking explanation predicts that (large) decreases in CEO age should be followed by comparably higher values in Book Leverage.

I then re-perform both types of DID analyses from the previous section while taking each of these policy measures as the dependent variable. Panel A of Table 2.7 presents the results for the retirement age analysis and Panel B presents those obtained according to age change groups. I only report the results for the models that include the full set of variables: those for the reduced models are similar. In the cases in which the dependent variable is part of the standard set of firm controls, I exclude this variable from the controls. For brevity, the coefficient estimates for the firm controls are omitted.

Neither the results in Panel A nor those in Panel B exhibit any statistically significant coefficient estimates that would support a negative relationship between CEO age and risk-taking. By contrast, Model (1) in Panel B indicates that large decreases in CEO age are followed by reductions in $R \& D$ intensity. This finding clearly contradicts the notion that younger CEOs are more inclined adopt risky policies. Additionally, in an unreported test excluding the firm

\footnotetext{
${ }^{24}$ Simple omission of those firm-years yields the same results.

${ }^{25}$ For robustness, I also check the effect on Market Leverage. The results are the same.
} 
Table 2.7: Effect on risk-related corporate policies

\begin{tabular}{|c|c|c|c|c|c|}
\hline Panel A: Retirement age as a proxy & $\begin{array}{c}(1) \\
\mathrm{R} \& \mathrm{D} / \\
\text { Assets }\end{array}$ & $\begin{array}{c}(2) \\
\text { Ln(Business } \\
\text { Segments) }\end{array}$ & $\begin{array}{c}(3) \\
\text { Segment } \\
\text { HHI }\end{array}$ & $\begin{array}{c}(4) \\
\text { Operating } \\
\text { Leverage }\end{array}$ & $\begin{array}{c}(5) \\
\text { Book } \\
\text { Leverage }\end{array}$ \\
\hline Treated $\times$ Post $\times$ Non-Retirement Age CEO & $\begin{array}{l}-0.0252 \\
(0.8343)\end{array}$ & $\begin{array}{l}-0.0414 \\
(0.4729)\end{array}$ & $\begin{array}{c}0.0192 \\
(0.4570)\end{array}$ & $\begin{array}{c}0.5547 \\
(0.3502)\end{array}$ & $\begin{array}{l}-0.6094 \\
(0.6495)\end{array}$ \\
\hline Treated $\times$ Post $\times$ Retirement Age CEO & $\begin{array}{l}-0.2257 \\
(0.2108)\end{array}$ & $\begin{array}{l}-0.0497 \\
(0.6696)\end{array}$ & $\begin{array}{c}0.0143 \\
(0.7504)\end{array}$ & $\begin{array}{c}0.3588 \\
(0.5105)\end{array}$ & $\begin{array}{l}-2.3819 \\
(0.1671)\end{array}$ \\
\hline $\begin{array}{l}\text { Firm Controls } \\
\text { Year Fixed Effects } \\
\text { Firm Fixed Effects } \\
\text { Number of Firms } \\
\text { Number of Observations } \\
\text { Adj. R-Squared }\end{array}$ & $\begin{array}{c}\text { Yes } \\
\text { Yes } \\
\text { Yes } \\
261 \\
1,929 \\
0.1203\end{array}$ & $\begin{array}{c}\text { Yes } \\
\text { Yes } \\
\text { Yes } \\
189 \\
1,175 \\
0.0912\end{array}$ & $\begin{array}{c}\text { Yes } \\
\text { Yes } \\
\text { Yes } \\
189 \\
1,175 \\
0.0867\end{array}$ & $\begin{array}{c}\text { Yes } \\
\text { Yes } \\
\text { Yes } \\
187 \\
1,229 \\
0.0228\end{array}$ & $\begin{array}{c}\text { Yes } \\
\text { Yes } \\
\text { Yes } \\
261 \\
1,929 \\
0.1850\end{array}$ \\
\hline Panel B: By age change groups & $\begin{array}{c}(1) \\
R \& D / \\
\text { Assets }\end{array}$ & $\begin{array}{c}(2) \\
\text { Ln(Business } \\
\text { Segments) }\end{array}$ & $\begin{array}{c}(3) \\
\text { Segment } \\
\text { HHI }\end{array}$ & $\begin{array}{c}(4) \\
\text { Operating } \\
\text { Leverage }\end{array}$ & $\begin{array}{c}(5) \\
\text { Book } \\
\text { Leverage }\end{array}$ \\
\hline Treated $\times$ Post $\times$ Stable/Increase & $\begin{array}{l}-0.1450 \\
(0.3433)\end{array}$ & $\begin{array}{l}-0.0437 \\
(0.4026)\end{array}$ & $\begin{array}{c}0.0470 \\
(0.1053)\end{array}$ & $\begin{array}{l}1.7448 \\
(0.1848)\end{array}$ & $\begin{array}{c}0.0017 \\
(0.9994)\end{array}$ \\
\hline Treated $\times$ Post $\times$ Moderate Decrease & $\begin{array}{c}0.1124 \\
(0.5482)\end{array}$ & $\begin{array}{l}-0.0787 \\
(0.3616)\end{array}$ & $\begin{array}{c}0.0021 \\
(0.9548)\end{array}$ & $\begin{array}{l}-0.1467 \\
(0.8495)\end{array}$ & $\begin{array}{l}-1.5388 \\
(0.3092)\end{array}$ \\
\hline Treated $\times$ Post $\times$ Large Decrease & $\begin{array}{l}-0.2554^{*} \\
(0.0757)\end{array}$ & $\begin{array}{l}-0.0084 \\
(0.9308)\end{array}$ & $\begin{array}{c}0.0172 \\
(0.6646)\end{array}$ & $\begin{array}{c}0.3644 \\
(0.4328)\end{array}$ & $\begin{array}{l}-1.6495 \\
(0.2756)\end{array}$ \\
\hline Firm Controls & Yes & Yes & Yes & Yes & Yes \\
\hline Year Fixed Effects & Yes & Yes & Yes & Yes & Yes \\
\hline Firm Fixed Effects & Yes & Yes & Yes & Yes & Yes \\
\hline Number of Firms & 261 & 158 & 158 & 150 & 261 \\
\hline Number of Observations & 1,929 & 1,116 & 1,116 & 1,019 & 1,929 \\
\hline Adj. R-Squared & 0.1211 & 0.0921 & 0.0886 & 0.0246 & 0.1843 \\
\hline
\end{tabular}

This table presents DID analyses for the effect of CEO age on risk-related corporate policies. In Panel A, the treatment effect is split for firms with sudden deaths of retirement age and non-retirement age CEOs and in Panel $\mathrm{B}$ for the three age change groups. In both panels, the dependent variables are RधD/Assets, LnBusiness Segments, Segment HHI, Operating Leverage, and Book Leverage, respectively. Definitions for the DID specifications can be found in the legends of Table 2.5, while Table A.2 in Appendix A.2 illustrates definitions for the (omitted) firm controls. All models include firm and year fixed effects, as well as a constant term. The $p$-values are based on standard errors clustered at the firm-level and are reported in parentheses, with *, **, and *** indicating significance levels of $10 \%, 5 \%$, and $1 \%$, respectively. 
controls, Model (3) of Panel B shows reduced diversification, in terms of the distribution of the firms' sales across their business segments, for the group of firms in which CEO age remained stable or increased. For the remaining firm policies - that is, for diversification through the number of business segments, operating leverage, and book leverage- the results reveal no statistically significant effect CEO changes, either for the stable/increase group or for the groups that experienced a decrease in CEO age. Notably, Models (2) to (4) contain fewer observations because the Compustat Historical Segments data and Compustat quarterly data are only available from 1976 and 1962, respectively. However, since in the unreported analyses I find at least one statistically significant coefficient estimate, I remain confident that the non-significant results for these models are not merely attributable to a lack of statistical power.

In sum, I find no evidence in favor of Hypothesis H2a. In fact, the evidence in this section stands in clear contradiction to the hitherto accepted perception of a negative relationship between CEOs' ages and their risk-taking behavior. If anything, I observe some indications that younger CEOs reduce the riskiness of the firms' policies rather than increasing it. This leaves the question of what precisely drives the effect of CEO age on firm risk. The section that follows will detail tests for the alternative explanation suggested in Section 2.2.2.

\subsubsection{CEO age and the market's knowledge}

The market's knowledge explanation suggests that the higher volatility associated with younger CEOs is driven by the market's lack of knowledge about these young CEOs and the associated uncertainty regarding how they might affect future policies and, thus, future profits. To determine whether the increased volatility the follows large decreases decreases in CEO age is mainly driven by increased uncertainty regarding the CEOs' abilities, I focus on specific circumstances in which I expect this effect to be particularly strong - that is, when uncertainty about the predecessor was low.

I examine two subgroups of events in which I expect the deceased to have been particularly well known - that is, sudden deaths of long-tenured or founder CEOs, respectively. Long-tenured CEOs may be considered to be well known because market participants mostly learn about a CEO's abilities during the early years of his or her tenure, after which they become a sort of "known quantity" to the market (Pan et al., 2015). A similar argument may be made for founder CEOs, who shape the direction of their firms from the very beginning (e.g., Fahlenbrach, 2009). Since they are so intertwined with their firms, all that is known about the firm can be directly related to the person as well, so that the CEO-related extra portion of uncertainty should be low 
in these firms. Not only can a long-tenured or founder CEO be expected to be well known, the person-firm match should be similarly well assessed by the market participants. I expect the effect of a decrease in CEO age to be particularly pronounced in both subgroups.

I test this expectation empirically by splitting the sample along these two dimensions and performing the analyses from Section 2.4.1 for the emerging subgroups. First, I split the sample into treated firms - and their respective control firms - with long- and short-tenured deceased CEOs, respectively. Using the hand-collected data on the CEOs, I define a deceased CEO as having been long-tenured if they had held office for more than four years. ${ }^{26}$ This definition aligns with that offered by Jenter and Kanaan (2015). Accordingly, short-tenured deceased CEOs had held office for four years or less. Of the 131 events included in the sample, 83 (48) fall into the long-tenured (short-tenured) group. Table 2.8 illustrates the results: whereas Panel A contains those in which retirement age serves as a proxy for the age change and Panel B containes those for the analyses by age change groups. Again, the coefficient estimates for the control variables are omitted for brevity.

The results reveal that the effect of increasing volatility induced by decreased CEO age only occurs in cases in which the deceased had long tenure. Models (1) and (2) demonstrate that for this subgroup, the effect is (highly) statistically significant and holds for the retirement age analysis (Panel A) as well as for the analyses according to age change groups (Panel B). By contrast, the effect is not evident for the group of short-tenured deceased CEOs, as demonstrated by Models (3) and (4) in both panels. The (unreported) results for idiosyncratic volatility are basically the same.

Second, I use the hand-collected data on whether the deceased was one of the firm's founders and split the sample into founder deceased and non-founder deceased firms and their respective control firms. Among the 131 sample events, I identify 35 founder CEOs. Table 2.9 presents the results. As in the previous analysis, Panel A contains the ones for the retirement age analyses and Panel B contains the ones for the analyses by age change groups. Again, the coefficient estimates for the control variables are omitted for brevity.

\footnotetext{
${ }^{26}$ The data-collection process reveals the full CEO history for the entire sample period from year $\tau-4$ through year $\tau+4$ around the event in year $\tau$. If available, I also collect the dates at which the CEOs assumed office. On the basis of this data, I determine the CEOs' tenure in two steps. First, if available, I calculate the difference in years between the year in which they became CEO and the year of their death. Second, for the remaining CEOs I calculate the 'sample tenure' by counting the number of years in which they had been in office between year $\tau-4$ and year $\tau$. If a deceased individual had already been the CEO in year $\tau-4$, I assign them to the long-tenured group. Hence, although I do not have information about the exact tenure for all the deceased CEOs in the sample, I can nonetheless determine whether they had been in office for more or less than four years.
} 
Table 2.8: Does the tenure of the deceased CEO matter?

\begin{tabular}{|c|c|c|c|c|}
\hline \multirow[t]{2}{*}{ Panel A: Retirement age as proxy } & \multicolumn{2}{|c|}{ Long-tenured deceased } & \multicolumn{2}{|c|}{ Short-tenured deceased } \\
\hline & $\begin{array}{c}(1) \\
\text { Volatility }\end{array}$ & $\begin{array}{c}(2) \\
\text { Volatility }\end{array}$ & $\begin{array}{c}(3) \\
\text { Volatility }\end{array}$ & $\begin{array}{c}(4) \\
\text { Volatility }\end{array}$ \\
\hline Treated $\times$ Post $\times$ Non-Retirement Age CEO & $\begin{array}{l}-1.8385 \\
(0.2595)\end{array}$ & $\begin{array}{l}-2.2630 \\
(0.1433)\end{array}$ & $\begin{array}{c}2.6396 \\
(0.3521)\end{array}$ & $\begin{array}{c}1.9416 \\
(0.4596)\end{array}$ \\
\hline Treated $\times$ Post $\times$ Retirement Age CEO & $\begin{array}{c}6.2701^{* *} \\
(0.0143)\end{array}$ & $\begin{array}{c}6.4535^{* * *} \\
(0.0040)\end{array}$ & $\begin{array}{l}-0.2832 \\
(0.8973)\end{array}$ & $\begin{array}{l}-0.0865 \\
(0.9666)\end{array}$ \\
\hline Firm Controls & No & Yes & No & Yes \\
\hline Year Fixed Effects & Yes & Yes & Yes & Yes \\
\hline Firm Fixed Effects & Yes & Yes & Yes & Yes \\
\hline Number of Firms & 166 & 166 & 96 & 96 \\
\hline Number of Observations & 1,264 & 1,264 & 665 & 665 \\
\hline Adj. R-Squared & 0.2832 & 0.3198 & 0.3181 & 0.3310 \\
\hline \multicolumn{5}{|l|}{ Panel B: By age change groups } \\
\hline & \multicolumn{2}{|c|}{ Long-tenured deceased } & \multicolumn{2}{|c|}{ Short-tenured deceased } \\
\hline & (1) & $(2)$ & (3) & (4) \\
\hline & Volatility & Volatility & Volatility & Volatility \\
\hline Treated $\times$ Post $\times$ Stable/Increase & $\begin{array}{l}-0.8606 \\
(0.7213)\end{array}$ & $\begin{array}{l}-1.4057 \\
(0.5238)\end{array}$ & $\begin{array}{l}-1.2604 \\
(0.7849)\end{array}$ & $\begin{array}{l}-2.2085 \\
(0.6072)\end{array}$ \\
\hline Treated $\times$ Post $\times$ Moderate Decrease & $\begin{array}{l}-2.6405 \\
(0.1725)\end{array}$ & $\begin{array}{c}-3.7864^{*} \\
(0.0669)\end{array}$ & $\begin{array}{c}2.8552 \\
(0.3454)\end{array}$ & $\begin{array}{c}2.3954 \\
(0.4040)\end{array}$ \\
\hline Treated $\times$ Post $\times$ Large Decrease & $\begin{array}{l}4.9612^{* *} \\
(0.0414)\end{array}$ & $\begin{array}{c}5.3965^{* *} \\
(0.0120)\end{array}$ & $\begin{array}{c}4.5768 \\
(0.1791)\end{array}$ & $\begin{array}{c}4.4820 \\
(0.1725)\end{array}$ \\
\hline Firm Controls & No & Yes & No & Yes \\
\hline Year Fixed Effects & Yes & Yes & Yes & Yes \\
\hline Firm Fixed Effects & Yes & Yes & Yes & Yes \\
\hline Number of Firms & 166 & 166 & 96 & 96 \\
\hline Number of Observations & 1,264 & 1,264 & 665 & 665 \\
\hline Adj. R-Squared & 0.2798 & 0.3196 & 0.3195 & 0.3339 \\
\hline
\end{tabular}

This table presents DID analyses for the effect of CEO age on firm risk, estimated for subsamples of long-tenured (Models (1) and (2)) and short-tenured (Models (3) and (4)) deceased CEOs. In Panel A, the treatment effect is split for firms with sudden deaths of retirement age and non-retirement age CEOs and in Panel B for the three age change groups. In all models, the dependent variable is Volatility. Definitions for the DID specifications can be found in the legends of Table 2.5, while Table A.2 in Appendix A.2 illustrates definitions for the (omitted) firm controls. All models include firm and year fixed effects, as well as a constant term. The $p$-values are based on standard errors clustered at the firm-level and are reported in parentheses, with *, $* *$, and $* * *$ indicating significance levels of $10 \%, 5 \%$, and $1 \%$, respectively. 
Table 2.9: Does it matter if the deceased CEO was the founder?

\begin{tabular}{|c|c|c|c|c|}
\hline \multirow[t]{2}{*}{ Panel A: Retirement age as proxy } & \multicolumn{2}{|c|}{ Founder deceased } & \multicolumn{2}{|c|}{ Non-founder deceased } \\
\hline & $\begin{array}{c}(1) \\
\text { Volatility }\end{array}$ & $\begin{array}{c}(2) \\
\text { Volatility }\end{array}$ & $\begin{array}{c}(3) \\
\text { Volatility }\end{array}$ & $\begin{array}{c}(4) \\
\text { Volatility }\end{array}$ \\
\hline Treated $\times$ Post $\times$ Non-Retirement Age CEO & $\begin{array}{l}-0.1318 \\
(0.9754)\end{array}$ & $\begin{array}{l}-0.5806 \\
(0.8898)\end{array}$ & $\begin{array}{l}-0.7371 \\
(0.5990)\end{array}$ & $\begin{array}{l}-0.6582 \\
(0.6155)\end{array}$ \\
\hline Treated $\times$ Post $\times$ Retirement Age CEO & $\begin{array}{l}7.4827^{*} \\
(0.0531)\end{array}$ & $\begin{array}{c}8.5998^{* *} \\
(0.0196)\end{array}$ & $\begin{array}{c}0.5486 \\
(0.7727)\end{array}$ & $\begin{array}{c}1.2587 \\
(0.5062)\end{array}$ \\
\hline Firm Controls & No & Yes & No & Yes \\
\hline Year Fixed Effects & Yes & Yes & Yes & Yes \\
\hline Firm Fixed Effects & Yes & Yes & Yes & Yes \\
\hline Number of Firms & 70 & 70 & 191 & 191 \\
\hline Number of Observations & 524 & 524 & 1,405 & 1,405 \\
\hline Adj. R-Squared & 0.3047 & 0.3416 & 0.2888 & 0.3101 \\
\hline \multicolumn{5}{|l|}{ Panel B: By age change groups } \\
\hline & \multicolumn{2}{|c|}{ Founder deceased } & \multicolumn{2}{|c|}{ Non-founder deceased } \\
\hline & $\begin{array}{c}(1) \\
\text { Volatility }\end{array}$ & $\begin{array}{c}(2) \\
\text { Volatility }\end{array}$ & $\begin{array}{c}(3) \\
\text { Volatility }\end{array}$ & $\begin{array}{c}(4) \\
\text { Volatility }\end{array}$ \\
\hline Treated $\times$ Post $\times$ Stable/Increase & $\begin{array}{c}0.4943 \\
(0.9506)\end{array}$ & $\begin{array}{l}-1.2898 \\
(0.8693)\end{array}$ & $\begin{array}{l}-1.7683 \\
(0.4415)\end{array}$ & $\begin{array}{l}-1.3712 \\
(0.5249)\end{array}$ \\
\hline Treated $\times$ Post $\times$ Moderate Decrease & $\begin{array}{c}0.9439 \\
(0.8352)\end{array}$ & $\begin{array}{c}0.4954 \\
(0.9112)\end{array}$ & $\begin{array}{l}-1.8304 \\
(0.2701)\end{array}$ & $\begin{array}{l}-1.7911 \\
(0.2659)\end{array}$ \\
\hline Treated $\times$ Post $\times$ Large Decrease & $\begin{array}{c}5.5715 \\
(0.1509)\end{array}$ & $\begin{array}{l}6.6504^{*} \\
(0.0778)\end{array}$ & $\begin{array}{l}3.5661^{*} \\
(0.0878)\end{array}$ & $\begin{array}{l}3.8506^{*} \\
(0.0656)\end{array}$ \\
\hline Firm Controls & No & Yes & No & Yes \\
\hline Year Fixed Effects & Yes & Yes & Yes & Yes \\
\hline Firm Fixed Effects & Yes & Yes & Yes & Yes \\
\hline Number of Firms & 70 & 70 & 191 & 191 \\
\hline Number of Observations & 524 & 524 & 1,405 & 1,405 \\
\hline Adj. R-Squared & 0.2992 & 0.3365 & 0.2944 & 0.3156 \\
\hline
\end{tabular}

This table presents DID analyses for the effect of CEO age on firm risk, estimated for subsamples of founder (Models (1) and (2)) and non-founder (Models (3) and (4)) deceased CEOs. In Panel A, the treatment effect is split for firms with sudden deaths of retirement age and non-retirement age CEOs and in Panel B for the three age change groups. In all models, the dependent variable is Volatility. Definitions for the DID specifications can be found in the legends of Table 2.5, while Table A.2 in Appendix A.2 illustrates definitions for the (omitted) firm controls. All models include firm and year fixed effects, as well as a constant term. The $p$-values are based on standard errors clustered at the firm-level and are reported in parentheses, with *, **, and *** indicating significance levels of $10 \%, 5 \%$, and $1 \%$, respectively. 
First, the results in Panel A are fully in line with the expectations in that they clearly show that the age-related increase in volatility only occurs in the subsample of founder CEOs (Models (1) and (2)) but not for non-founder CEOs (Models (3) and (4)). Notably, the occurrence of the effect in the considerably smaller founder sample further strengthens the result in its demonstration that the insignificance in the non-founder sample is not simply due to a lack of statistical power. Beyond that, the results in Panel B are not as unambiguous as those of the foregoing analysis, since the increase in volatility after large decreases in CEO age appears in both subsamples, with coefficient estimates being statistically significant at the ten percent level in Models (2) through (4). This may be caused by a number of well-known, long-tenured CEOs in the non-founder subsample, which may hamper a clear differentiation of this subgroup as being hardly known by the market. However, the magnitude of the coefficient estimates still suggests that the increase in volatility is greater for deceased founder CEOs. The (unreported) results for idiosyncratic volatility are similar but loose their statistical significance in Panel B.

In sum, the results in this section demonstrate that the effect of age change on volatility particularly occurs in the subsamples in which the deceased CEO can be assumed to have been well known to the market participants. This supports the notion expressed by Hypothesis $\mathrm{H} 2 \mathrm{~b}$ - that an increase in age-related uncertainty only becomes observable if the uncertainty surrounding the predecessor was low. Consequently, the evidence supports the market's knowledge explanation.

\subsection{Additional analyses and robustness tests}

\subsubsection{Parallel trends assumption}

The crucial identification assumption of the DID is that the treated and control firms follow parallel trends in the outcome variable (i.e., volatility) prior to treatment (in year $\tau$ ) and that these trends would have continued if the treatment had not occurred (i.e., that the CEO had not changed). While the latter is not testable, I conduct the following three analyses to test for parallel trends during the pre-event period.

First, a graphical inspection offers a simple means of obtaining a first impression of the trends in volatility over time. Figure 2.1 plots the mean stock return volatility of the treated and the control group of firms over the course of the study's sample period from year $\tau-4$ to $\tau+4$. 
With the exception of the first sample year ${ }^{27}$, the figure clearly illustrates similar patterns during the pre-event period, providing initial support for the parallel trends assumption in the context of the present study.

Figure 2.1: Mean volatility over time

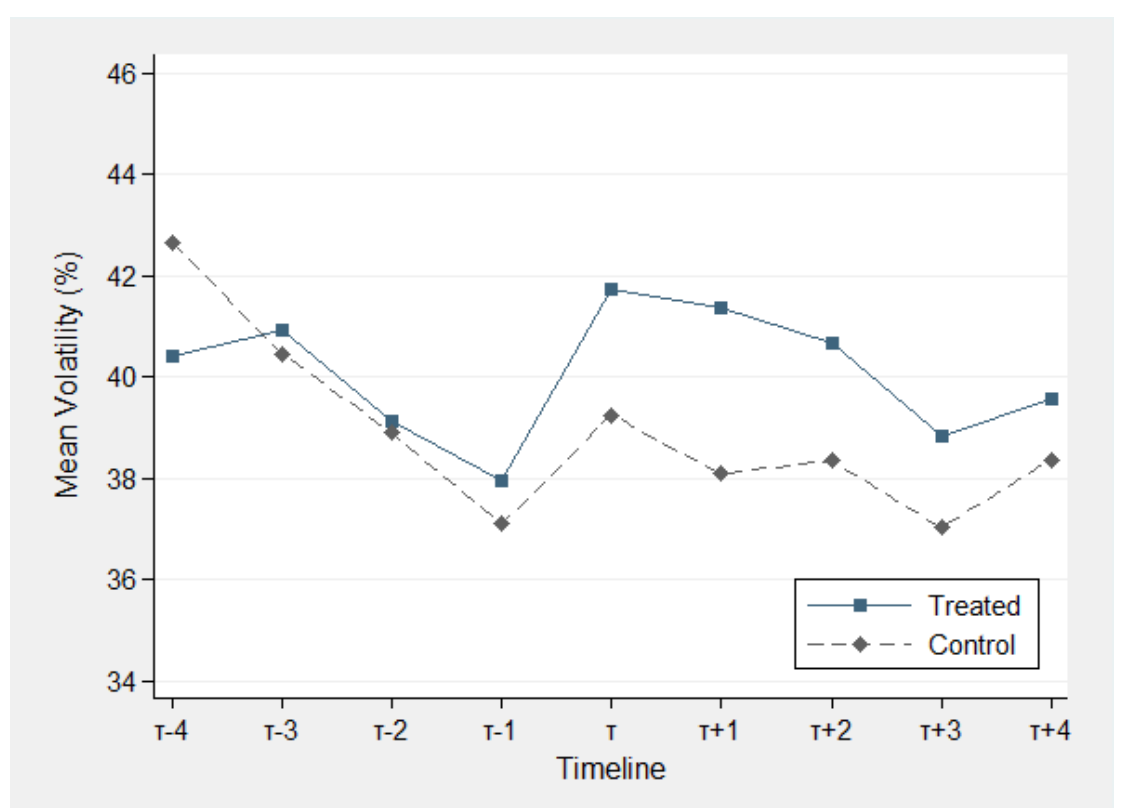

This figures illustrates mean stock return volatility for treated and control firms over time for the study's sample period of interest, that is, from the four years before to the four years after the year of the sudden deaths $(\tau)$.

Second, I conduct placebo tests during the pre-event period. In particular, I re-estimate the model from Equation (2.1) for the four years prior to the actual treatment and define placebo treatments in years $\tau-2$ or $\tau-1$, respectively. Consequently, the post indicators in these analyses take the value of one for the years $\tau-2$, or in the second version $\tau-1$, or later. ${ }^{28}$ These placebo treatments should not reveal any effect similar to that observed for the actual treatment. Hence, I expect the coefficient estimates on the DID interaction terms to be indistinguishable from zero. I perform these tests on the subsample of long-tenured deceased CEOs because, in this case, I would expect the cleanest DID effect. However, unreported tests on the entire sample yield the same results. Panel A of Table 2.10 illustrates these results. As expected, the volatility increase for firms with large decreases in CEO age is not observed in this test. Neither is it observed for placebo treatments in $\tau-2$ (Models (1) and (2)) or $\tau-1$ (Models (3) and (4)). All

\footnotetext{
${ }^{27}$ The reason for this most likely lies in the sorting out of some predecessor CEO observations, as outlined in Section 2.3.2.

${ }^{28}$ I make sure to only include matched pairs that have at least one observation for both treated and control firms available in the pre-placebo treatment period. In the analysis presented in Panel B, I require the same for the benchmark group.
} 
respective coefficient estimates are statistically insignificant.

Third, I estimate yearly treatment effects in the pre-event period. I re-estimate Equation (2.1) while adding further DID interaction terms for the individual pre-event years $\tau-2$ and $\tau-1$ for each of the two groups. The omitted years $\tau-4$ and $\tau-3$ then serve as the benchmark group. If the treated and control firms followed parallel trends with respect to volatility, the coefficient estimates for the years before treatment should be indistinguishable from zero. As for the placebo tests, I perform this analysis on the subsample of firms with long-tenured deceased CEOs. Panel B of Table 2.10 illustrates the results. Models (1) and (2) present the analyses as described above, while in Models (3) and (4) years $\tau-2$ through $\tau-4$ serve as the benchmark. As expected, the coefficient estimates for the pre-event years are statistically insignificant throughout all the models.

In sum, the analyses presented in this section fail to identify differences the volatility trends between treated and control firms during the pre-event period. This supports the idea that the parallel trends assumption should be satisfied for the sample in this study.

\subsubsection{Alternative age change groups}

The definition of the three age change groups plays a key role in the present study's examination of the occurrence and economic magnitude of the effect that CEO age has on firm risk. I base the main definition on the tercile thresholds of the distribution of the change in CEO age while sorting the threshold events into the respective lower categories. To ensure that my results are not simply driven by this particular choice, I test the following two alternative definitions. ${ }^{29}$

First, I redefine the age change groups by sorting the events that lay on the tercile thresholds of -4 and -13 into the respective upper categories. The Increase/Stable group then comprises 47 events with changes in age from -4 to 20 , the Moderate Decrease group 43 events with changes in age from -13 to -5, and the Large Decrease group 41 events with changes in age from -35 to -14. When I use these alternative tercile groups and perform the analyses from Section 2.4 again, the results remain basically unchanged.

Second, since the tercile groups to some extent still combine events that differ with respect the change in age, I define alternative groups based on quartiles. Therefore, I take the quartile thresholds of $-15,-9$, and -1 to define the four groups Increase [0;20], Decrease [-8;-1], Decrease

\footnotetext{
${ }^{29}$ Most of the results are unreported but are available upon request.
} 
Table 2.10: Tests of the parallel trends assumption

\begin{tabular}{|c|c|c|c|c|}
\hline \multicolumn{5}{|l|}{ Panel A: Placebo treatments } \\
\hline & \multicolumn{2}{|c|}{ Post, if year $\geq \tau-2$} & \multicolumn{2}{|c|}{ Post, if year $\geq \tau-1$} \\
\hline & $\begin{array}{c}(1) \\
\text { Volatility }\end{array}$ & $\begin{array}{c}(2) \\
\text { Volatility }\end{array}$ & $\begin{array}{c}(3) \\
\text { Volatility }\end{array}$ & $\begin{array}{c}(4) \\
\text { Volatility }\end{array}$ \\
\hline Treated $\times$ Post $\tau-3 \times$ Non-Retirement Age CEO & $\begin{array}{c}0.0093 \\
(0.9950)\end{array}$ & $\begin{array}{l}-0.0152 \\
(0.9923)\end{array}$ & & \\
\hline Treated $\times$ Post $\tau-3 \times$ Retirement Age CEO & $\begin{array}{c}0.4510 \\
(0.8160)\end{array}$ & $\begin{array}{c}1.8053 \\
(0.3622)\end{array}$ & & \\
\hline Treated $\times$ Post $\tau-2 \times$ Non-Retirement Age CEO & & & $\begin{array}{c}0.3060 \\
(0.8621)\end{array}$ & $\begin{array}{c}0.2424 \\
(0.8959)\end{array}$ \\
\hline Treated $\times$ Post $\tau-2 \times$ Retirement Age CEO & & & $\begin{array}{c}1.1420 \\
(0.5404)\end{array}$ & $\begin{array}{c}1.9462 \\
(0.3195) \\
\end{array}$ \\
\hline Firm Controls & No & Yes & No & Yes \\
\hline Year Fixed Effects & Yes & Yes & Yes & Yes \\
\hline Firm Fixed Effects & Yes & Yes & Yes & Yes \\
\hline Number of Firms & 166 & 166 & 166 & 166 \\
\hline Number of Observations & 636 & 636 & 636 & 636 \\
\hline Adj. R-Squared & 0.3175 & 0.3460 & 0.3179 & 0.3459 \\
\hline \multicolumn{5}{|l|}{ Panel B: Yearly treatment effects } \\
\hline & \multicolumn{2}{|c|}{ Benchm. $\tau-3 \mid 4$} & \multicolumn{2}{|c|}{ Benchm. $\tau-2|3| 4$} \\
\hline & $\begin{array}{c}(1) \\
\text { Volatility }\end{array}$ & $\begin{array}{c}(2) \\
\text { Volatility }\end{array}$ & $\begin{array}{c}(3) \\
\text { Volatility }\end{array}$ & $\begin{array}{c}(4) \\
\text { Volatility }\end{array}$ \\
\hline Treated $\times$ Year $\tau-2 \times$ Non-Retirement Age CEO & $\begin{array}{l}-1.2210 \\
(0.4640)\end{array}$ & $\begin{array}{l}-1.3551 \\
(0.4226)\end{array}$ & & \\
\hline Treated $\times$ Year $\tau-1 \times$ Non-Retirement Age CEO & $\begin{array}{l}-1.7627 \\
(0.3317)\end{array}$ & $\begin{array}{l}-2.4235 \\
(0.1752)\end{array}$ & $\begin{array}{l}-1.2883 \\
(0.4296)\end{array}$ & $\begin{array}{l}-1.9149 \\
(0.2445)\end{array}$ \\
\hline Treated $\times$ Post $\times$ Non-Retirement Age CEO & $\begin{array}{l}-2.7681 \\
(0.1846)\end{array}$ & $\begin{array}{r}-3.4201^{*} \\
(0.0881)\end{array}$ & $\begin{array}{l}-2.2527 \\
(0.2353)\end{array}$ & $\begin{array}{l}-2.8717 \\
(0.1144)\end{array}$ \\
\hline Treated $\times$ Year $\tau-2 \times$ Retirement Age CEO & $\begin{array}{l}-1.5430 \\
(0.5143)\end{array}$ & $\begin{array}{l}-0.4605 \\
(0.8480)\end{array}$ & & \\
\hline Treated $\times$ Year $\tau-1 \times$ Retirement Age CEO & $\begin{array}{l}-0.5234 \\
(0.8273)\end{array}$ & $\begin{array}{c}0.3893 \\
(0.8713)\end{array}$ & $\begin{array}{c}0.0875 \\
(0.9690)\end{array}$ & $\begin{array}{c}0.6155 \\
(0.7828)\end{array}$ \\
\hline Treated $\times$ Post $\times$ Retirement Age CEO & $\begin{array}{l}5.5838^{*} \\
(0.0736) \\
\end{array}$ & $\begin{array}{c}6.2479 * * \\
(0.0299)\end{array}$ & $\begin{array}{c}6.2044^{* *} \\
(0.0209)\end{array}$ & $\begin{array}{c}6.4903^{* * *} \\
(0.0051)\end{array}$ \\
\hline Firm Controls & No & Yes & No & Yes \\
\hline Year Fixed Effects & Yes & Yes & Yes & Yes \\
\hline Firm Fixed Effects & Yes & Yes & Yes & Yes \\
\hline Number of Firms & 166 & 166 & 166 & 166 \\
\hline Number of Observations & 1,264 & 1,264 & 1,264 & 1,264 \\
\hline Adj. R-Squared & 0.2818 & 0.3189 & 0.2824 & 0.3196 \\
\hline
\end{tabular}

This table presents the results from tests of the parallel trends assumption. All tests in this table are performed on the subsample of long-tenured deceased CEOs and are based on the retirement age analyses. Panel A presents placebo tests on the pre-event sample with placebo treatments in $\tau-2$ (Models (1) and (2)) and $\tau-1$ (Models (3) and (4)). Panel B illustrates tests including yearly treatment effects for the single pre-event years $\tau-2$ and $\tau-1$ for each of the two groups. In all models, the dependent variable is Volatility. Definitions for the DID specifications can be found in the legends of Table 2.5, while Table A.2 in Appendix A.2 illustrates definitions for the (omitted) firm controls. All models include firm and year fixed effects, as well as a constant term. The $p$-values are based on standard errors clustered at the firm-level and are reported in parentheses, with *, **, and $* * *$ indicating significance levels of $10 \%, 5 \%$, and $1 \%$, respectively. 
[-14;-9], and Decrease [-35;-15], which comprise 30,32, 36, and 33 events, respectively. Notably, unlike the tercile groups, this categorization explicitly differentiates between increases and decreases in CEO age. I then use these quartile groups and re-perform my analyses. Table 2.11 presents the volatility results.

Table 2.11: Effect on volatility by age change groups based on quartiles

\begin{tabular}{|c|c|c|c|c|}
\hline & \multicolumn{2}{|c|}{ Overall Volatility } & \multicolumn{2}{|c|}{ Idiosyncratic Volatility } \\
\hline & $\begin{array}{c}(1) \\
\text { Volatility }\end{array}$ & $\begin{array}{c}(2) \\
\text { Volatility }\end{array}$ & $\begin{array}{c}(3) \\
\text { IdioVol }\end{array}$ & $\begin{array}{c}(4) \\
\text { IdioVol }\end{array}$ \\
\hline Treated $\times$ Post $\times$ Increase $[0 ; 20]$ & $\begin{array}{c}-5.1143^{* *} \\
(0.0197)\end{array}$ & $\begin{array}{c}-5.0482^{* *} \\
(0.0160)\end{array}$ & $\begin{array}{c}-4.5480^{* *} \\
(0.0251)\end{array}$ & $\begin{array}{c}-4.5838^{* *} \\
(0.0161)\end{array}$ \\
\hline Treated $\times$ Post $\times$ Decrease $[-8 ;-1]$ & $\begin{array}{c}2.8016 \\
(0.2141)\end{array}$ & $\begin{array}{c}2.7507 \\
(0.2088)\end{array}$ & $\begin{array}{c}3.2088 \\
(0.1575)\end{array}$ & $\begin{array}{c}3.1246 \\
(0.1493)\end{array}$ \\
\hline Treated $\times$ Post $\times$ Decrease $[-14 ;-9]$ & $\begin{array}{l}-0.5609 \\
(0.7620)\end{array}$ & $\begin{array}{l}-1.0726 \\
(0.5563)\end{array}$ & $\begin{array}{l}-0.9227 \\
(0.5767)\end{array}$ & $\begin{array}{l}-1.5268 \\
(0.3466)\end{array}$ \\
\hline Treated $\times$ Post $\times$ Decrease $[-35 ;-15]$ & $\begin{array}{l}4.1052^{*} \\
(0.0800) \\
\end{array}$ & $\begin{array}{c}4.8481^{* *} \\
(0.0286) \\
\end{array}$ & $\begin{array}{c}3.8215 \\
(0.1121) \\
\end{array}$ & $\begin{array}{c}4.5271^{* *} \\
(0.0402) \\
\end{array}$ \\
\hline Firm Controls & No & Yes & No & Yes \\
\hline Year Fixed Effects & Yes & Yes & Yes & Yes \\
\hline Firm Fixed Effects & Yes & Yes & Yes & Yes \\
\hline Number of Firms & 261 & 261 & 261 & 261 \\
\hline Number of Observations & 1,929 & 1,929 & 1,929 & 1,929 \\
\hline Adj. R-Squared & 0.2825 & 0.3040 & 0.2205 & 0.2518 \\
\hline
\end{tabular}

This table presents DID analyses for the effect of CEO age on firm risk. In the regressions the treatment effect is split for four age change groups. In all models, the dependent variable is Volatility. Treated is a dummy variable equal to one for firms that experienced a sudden death and zero for the control firms. Post is a dummy variable equal to one for the four years after and zero for the four years prior to the event. Increase [0;20], Decrease [-8;-1], Decrease [-14;-9], and Decrease [-35;-15] are dummy variables equal to one for treated firms with a change in CEO age of 0 to $20,-8$ to $-1,-14$ to -9 , and -35 to -15 , respectively, and zero otherwise. Definitions for the (omitted) firm controls can be found in Table A.2 in Appendix A.2. All models include firm and year fixed effects, as well as a constant term. The $p$-values are based on standard errors clustered at the firm-level and are reported in parentheses, with $*, * *$, and $* * *$ indicating significance levels of $10 \%, 5 \%$, and $1 \%$, respectively.

The results are in line with the findings of the main analyses. Specifically, they highlight that the effect of an increase in volatility mainly occurs when CEO age decreases to a large extent. Moreover, they provide additional evidence for the group of firms that increased CEO age. This group experienced a decline in volatility following the CEO turnover, which further supports the notion of a negative relation between CEO age and firm risk. Besides, the (unreported) results for the tests of the two alternative explanations also generally confirm the earlier findings, albeit with slightly reduced statistical significance. Overall, the results are robust to alternative definitions of age change groups. 


\subsubsection{Further robustness checks}

I conduct several further tests to check the results' robustness to some of the choices made throughout the analyses. ${ }^{30}$ First, I test the following three alternatives to the choice of events considered: (i) I exclude eight events in which the deceased had been in office for less than two years because it is questionable whether these CEOs had had the opportunity to significantly influence the firm's direction during their brief tenure; (ii) I exclude the four events that occurred in 1952, which I initially decided to retain in the sample, although only two years of data are available from prior to the event. The results for both robustness checks are basically the same as those for the main analyses. (iii) I exclude 12 events of financial firms (Fama-French 49 industries 45-48), which are matched only with other financial firms, owing to their specific financial characteristics. The only difference from the results of the main analyses is the weak evidence for reduced firm diversification in association with younger CEOs. The remaining results are qualitatively the same. Second, I check the results' robustness to the following two adjustments of the sample period: (i) To rule out the possibility that short-term increases in uncertainty surrounding sudden deaths drive the increase in volatility, I also exclude year $\tau+1$ if the event occurred during the second half of the event year $\tau$. (ii) I re-estimate the models for a reduced sample period of three years before and after the event. Both tests confirm the earlier findings. Finally, I include Sales Growth as an additional control variable in the models, which related studies often consider as another factor influencing firm risk (e.g., Serfling, 2014; Cain and McKeon, 2016; Bernile et al., 2017) yet reduces the sample by a few observations. Again, the results remain essentially unchanged.

\subsection{Conclusion}

This paper uses sudden CEO deaths to provide new evidence for the relationship between CEO age and firm risk. Since this setting is more effective in alleviating concerns about the endogeneity of such analyses, my findings challenge those of previous studies.

Do younger CEOs really increase firm risk? The answer is yes, but for reasons other than those hitherto suggested by the literature. In particular, I find that while accounting for the endogenous choice of successor CEOs, large decreases in CEO age after sudden CEO deaths lead to significant increases in stock return volatility. This provides causal evidence that CEO age negatively influences firm risk and thus substantiates the findings reported by Serfling (2014) and

\footnotetext{
${ }^{30}$ The results are unreported but are available upon request.
} 
Peltomäki et al. (2020). However, I find no evidence to indicate that age also negatively influences CEOs' risk-taking behavior. This clearly contrasts with earlier findings and the often-invoked dichotomization of the "impetuous" youngsters and the "jaded old-timer". In fact, I find evidence that supports the alternative explanation that attributes the higher firm risk associated with younger CEOs to the market's lack of knowledge about their abilities, which causes uncertainty.

Overall, my results extent the understanding of how CEO age influences firm risk. Moreover, they highlight the importance of accounting for endogeneity. Future research should employ similarly exogenous settings to provide more causal evidence of how CEO characteristics influence corporate policies and outcomes. For firms, this study sheds light on a potential source of risk while implicitly suggesting a potential remedy - that is, comprehensive communication that can help the market to become familiar with the CEO. 


\section{A Appendix}

\section{A.1 Derivation of the final sample of events}

In this section, I describe in further detail the derivation of the final sample of sudden CEO death events considered in this study. Having begun with the list of 239 sudden CEO deaths provided by Quigley et al. (2017) and adding the 13 further events collected by Merz and Weidemann (2018), I obtain an initial sample of 252 events in which the CEO had died unexpectedly while in office. However, owing to limited data availability and the necessity of correcting a few inaccuracies in the original data, not all of these events can be included in the empirical analyses. Herein, I will explain the reasons for this.

First, 48 events are omitted from the initial sample because they cannot be merged with the CRSP/Compustat data set, meaning that the respective firm-year is not included in any of the two databases that provide the basis for this study's empirical analyses.

Second, I exclude 28 events lack necessary data for the estimation of the propensity score, as explained in Section 2.3.3. That is, these events lack data on any of the matching variables in the year prior to the event. Although some of the 176 remaining events cannot be used in the main analyses, I decided to retain as many events as possible for the propensity score estimation to improve the estimates' efficiency.

Third, another 36 events are omitted from the sample because they do not have necessary data available for a minimum of three years before and three years after the event. While the time span of interest in this study covers (up to) four years before and (up to) four years after the sudden deaths, I here relax this requirement somewhat in the interest of retaining a few more events in the sample. For the four events that occurred in 1952, I require only two years before and three years after, because accounting data are only available from 1950 onward. As noted in Section 2.5.3, the results are robust to the exclusion of these events.

Fourth, I exclude five events in which the deceased had held office for less than one year. In these cases, the CEOs cannot be assumed to have significantly influenced the firms policies.

Fifth, I remove three events in which, through further research, I could only confirm that the deceased were the chairmen but not that they were CEOs at the time of their deaths. These events include the deaths of James Alexander Gray Jr. from R. J. Reynolds Tobacco Company 
(event date: 29 October 1952), Roy H. Glover from Anaconda Co (event date: 31 March 1958), and Norman Macbeth from Kollmorgen Corporation (event date: 13 March 1979).

Finally, I omit one event in which the deceased was assigned to the wrong firm in the original CEO death data set. In particular, the sudden death of Edmond Ward from the American District Telegraph Company (ADT.) was incorrectly assigned to GVKEY 1375 and PERMNO 17670, which belong to the American Distilling Company. ADT is not included in CRSP/Compustat for the time of Mr. Ward's death in December 1951.

One might argue that this event, in addition to the three chairmen events, should have been excluded prior to the PSM. However, since they only became apparent during the extensive data collection process for the firms' CEO history - and, thus, after the PSM-I was only able to exclude them at that point. Nevertheless, I remain confident that their inclusion does not negatively influence the quality of the PSM for three reasons: first, they also represent deaths of high-profile corporate figures, and several studies analyze the deaths of both chairpersons and CEOs conjointly (e.g., Salas, 2010; Jenter et al., 2016). Second, the universe of potential control firms for each event is huge (i.e., all firms with relevant data in CRSP/Compustat serve as potential control firms). Therefore, even if one of the three chairmen's events had taken a match that would have been better for any of the other CEO events, there remain plenty of potential control firms that would allow each to find another high-quality match. Third, the descriptive statistics for the treated and control firms (Section 2.3.6) as well as the tests for the parallel trends assumption (Section 2.5.1) provide support that the matching procedure produced two comparable groups.

Table A.1 summarizes the derivation of the final sample of events considered for the empirical analyses. The final sample comprises 131 sudden CEO deaths that occurred between 1952 and 2014. 
Table A.1: Derivation of the sudden CEO deaths sample

\begin{tabular}{|c|c|c|}
\hline & & ents \\
\hline Collected by Quigley et al. (2017) [1950-2008] & + & 239 \\
\hline Added by Merz and Weidemann (2018) [2009-2017] & + & 13 \\
\hline Events identified & & 252 \\
\hline Events that could not be merged with CRSP/Compustat & - & 48 \\
\hline Missing data for any of the matching variables in the year before the event & - & 28 \\
\hline Events included in propensity score estimation & & 176 \\
\hline Less than $+/-3$ years data available (exc. 1952) & - & 36 \\
\hline Deceased with tenure of less than one year & - & 5 \\
\hline Deceased was the chairperson and not the CEO & - & 3 \\
\hline Deceased assigned to the wrong firm & - & 1 \\
\hline Events included in empirical analyses & & 131 \\
\hline
\end{tabular}

This table provides an overview of the derivation of the final sample of sudden death events considered for the empirical analyses. 


\section{A.2 Miscellaneous}

Table A.2: Variable definitions

\begin{tabular}{|c|c|c|}
\hline Variable & Definition & Data Source \\
\hline \multicolumn{3}{|l|}{ Volatility Measures } \\
\hline Volatility $(\%)$ & $\begin{array}{l}\text { Annualized standard deviation of daily stock returns of the firm's } \\
\text { fiscal year. }\end{array}$ & $C R S P$ \\
\hline IdioVol $(\%)$ & Annualized standard deviation of daily residuals, obtained from & $C R S P \&$ \\
\hline & $\begin{array}{l}\text { Fama-French three-factor model estimations, of the firm's fiscal } \\
\text { year. The factor model is estimated on a yearly basis using data } \\
\text { from Kenneth R. French's data library. }\end{array}$ & $\begin{array}{l}\text { French's } \\
\text { data library }\end{array}$ \\
\hline \multicolumn{3}{|l|}{ Further Variables } \\
\hline CEO Age & Age of the current CEO. & $\begin{array}{l}\text { ExecuComp \& } \\
\text { hand-collected }\end{array}$ \\
\hline Total Assets & Book value of assets, applied as the natural logarithm. & Compustat \\
\hline Book Leverage (\%) & $\begin{array}{l}\text { Sum of long-term debt and current liabilities divided by the book } \\
\text { value of total assets. }\end{array}$ & Compustat \\
\hline ROA $(\%)$ & $\begin{array}{l}\text { Return on assets, calculated as net income divided by the book } \\
\text { value of assets. }\end{array}$ & Compustat \\
\hline R\&D/Assets (\%) & $\begin{array}{l}\text { R\&D expenditures divided by the book value of assets. Missing } \\
\text { values are set to zero. }\end{array}$ & Compustat \\
\hline CAPEX/Sales (\%) & Capital expenditures divided by sales. & Compustat \\
\hline Cash/Assets (\%) & $\begin{array}{l}\text { Cash and short-term investments divided by the book value of } \\
\text { assets. }\end{array}$ & Compustat \\
\hline Firm Age & $\begin{array}{l}\text { Number of years since the first trading on CRSP, with } 1925 \text { being } \\
\text { the earliest year possible. }\end{array}$ & $C R S P$ \\
\hline Operating Leverage & $\begin{array}{l}\text { Based on quarterly data and calculated as } \pi_{i, t} \text { times the ratio of } \\
\text { the three-year average values of sales and operating income after } \\
\text { depreciation of firm } i \text {, in which } \pi_{i, t} \text { is estimated for each firm-year } \\
\text { over the three-year window from } t \text { to } t+2 \text { using the following } \\
\text { regression } O I A D P Q_{q}=\alpha+\pi S A L E_{q}+\epsilon_{q} .\end{array}$ & Compustat \\
\hline Business Segments & $\begin{array}{l}\text { Number of business segments in which the firm operates, applied } \\
\text { as the natural logarithm. }\end{array}$ & Compustat \\
\hline Segment HHI & $\begin{array}{l}\text { Herfindahl-Hirschman Index based on the sales of the firm's } \\
\text { business segments and calculated as the sum of the squared ratios } \\
\text { of individual business segment sales to the firm's total sales. }\end{array}$ & Compustat \\
\hline
\end{tabular}

This table provides an overview of the different variables used, their definitions, and their sources. 
Table A.3: Propensity score estimation

\begin{tabular}{lc}
\hline & $(1)$ \\
& $\begin{array}{c}\text { Event } \\
\text { in } t+1\end{array}$ \\
\hline Ln(Total Assets) & 0.0781 \\
& $(0.1088)$ \\
Book Leverage & 0.0044 \\
& $(0.3444)$ \\
ROA & 0.0053 \\
& $(0.4262)$ \\
R\&D/Assets & 0.0134 \\
& $(0.4729)$ \\
CAPEX/Sales & -0.0017 \\
& $(0.6884)$ \\
Cash/Assets & 0.0084 \\
& $(0.1658)$ \\
Firm Age & $0.0291^{* * *}$ \\
& $(0.0007)$ \\
\hline Constant & Yes \\
Year Fixed Effects & Yes \\
Industry Fixed Effects & Yes \\
$\mathrm{N}$ & 216,988 \\
Chi-Squared & 258.71 \\
\hline
\end{tabular}

This table presents the estimation results of the complementary log-log model estimated to predict the propensity score, which represents the estimated likelihood of a firm experiencing a sudden CEO death in the following fiscal year, given the set of matching variables. The estimation is performed on the full CRSP/Compustat universe (for the years 1950-2017) with relevant data for the matching variables. The dependent variable takes the value of one if the firm experiences a sudden death in the following fiscal year. Definitions for the remaining variables can be found in Table A.2 in Appendix A.2. The model includes industry and year fixed effects, as well as a constant term. The $p$-values are reported in parentheses, and *,**, and *** indicate significance levels of $10 \%, 5 \%$, and $1 \%$, respectively. 
Table A.4: Control firm number taken

\begin{tabular}{ccc}
\hline $\begin{array}{c}\text { Control Firm } \\
\text { Number }\end{array}$ & Events & Cum. \% \\
\hline 1 & 61 & $46.6 \%$ \\
2 & 36 & $74.0 \%$ \\
3 & 23 & $91.6 \%$ \\
4 & 5 & $95.4 \%$ \\
5 & 5 & $99.2 \%$ \\
6 & 1 & $100.0 \%$ \\
\hline SUM & $\mathbf{1 3 1}$ & $\mathbf{1 0 0 . 0 \%}$ \\
\hline
\end{tabular}

This table provides an overview of the control firm number taken for the empirical analyses. In the matching procedure, I initially match several potential control firms to each of the treated firms. I then hand-collect data on the firms' CEO history and choose the best matched firm (i.e., with the smallest difference in the propensity score) that does not exhibit a CEO turnover during the two years before and three years after the corresponding treated firm's event. Hence, this table, for example, shows that for 23 treated firms I chose the third best matched firm as the respective control firm. 



\title{
3 Board Size, Firm Type, and Stock Return Volatility
}

Joint work with Alexander Merz.

Under review at the Financial Review.

\begin{abstract}
We document a negative and robust association between board size and firm risk, which is amplified in high-growth but not in complex firms. Contrary to prior literature, our evidence suggests that board size affects risk for different reasons. Across all firms and for complex ones, we find evidence of better monitoring when boards become larger, which suggests they prevent unnecessary risks. In high-growth firms, however, the evidence points towards inefficiencies of large boards reducing the volatility. Overall, this supports the notion that different firm types benefit from different board structures with regard to firm risk.
\end{abstract}

Acknowledgments: We thank Thorsten Beck, Olaf Korn, and seminar participants at the University of Goettingen, the 41st Annual Congress of the European Accounting Association, and the 2019 Annual Meeting of the Financial Management Association. All remaining errors are our own. 


\subsection{Introduction}

The board of directors is the principal means with which shareholders can monitor managers (John and Senbet, 1998). Many prior studies have emphasized the role of board size, and the negative effect of large boards on firm performance is well researched. ${ }^{1}$ Much less is known about the association of board size and firm risk. ${ }^{2}$ Cheng (2008) and Wang (2012) show that larger boards are associated with a reduction in the variability of corporate performance, with Cheng (2008) providing evidence that increasing communication and coordination problems are the underlying cause. He argues that decisions made by large groups exhibit less variability and are less extreme, as individual errors and different abilities often lead to compromises (Sah and Stiglitz, 1986, 1991). We call this the 'board inefficiency explanation', because it implies that larger boards are less able to function properly, and that the reduced volatility is the result of less efficient decision-making. However, larger boards can also benefit firms, since they can possess a greater capacity for monitoring (e.g., Boone et al., 2007), and if that causes lower risk, then it would be a positive outcome for shareholders. Neither Cheng (2008) nor Wang (2012) consider that the reduced variability could be due to better monitoring leading to a reduction in unnecessary risk-taking, which we call the 'monitoring capacity explanation'.

In this paper, we test the explanatory power of those two competing explanations for the association of board size and firm risk. The monitoring capacity explanation is not ruled out by the results reported by Cheng (2008), who finds that firms with larger boards, among other things, spend less on research and development $(\mathrm{R} \& \mathrm{D})$ and capital expenditures. This could be caused by either increased communication and coordination problems, or by improved monitoring. The fact that increasing the board's size can improve its monitoring function is well established. According to Bhagat and Black (1999) and Boone et al. (2007), additional directors can provide new knowledge and skills that become necessary as a firm ages. Moreover, tasks will likely be delegated to committees, and the more directors there are, the more efficiently the work can be spread among them (Klein, 2002). Finally, in contrast to theoretical arguments made by, for example, Jensen (1993), experimental literature shows that large groups can learn to work effectively and efficiently (Weber, 2006). Thus, having more directors could increase the board's capacity for properly monitoring managers and, if that prevents unnecessary risks, the volatility

\footnotetext{
${ }^{1}$ See, for example, Yermack (1996), Eisenberg et al. (1998), Conyon and Peck (1998), Mak and Kusnadi (2005), and Cheng et al. (2008).

${ }^{2}$ The board characteristics whose relations to firm risk have been investigated are diversity (Bernile et al., 2018; Giannetti and Zhao, 2019), gender (Sila et al., 2016), director independence and connectedness (Christy et al., 2013), and authority concentration (Tran and Turkiela, 2020).
} 
would go down.

Both explanations, therefore, predict a negative association between board size and firm risk, although it is only a positive outcome in the case of the monitoring capacity explanation. Distinguishing between them thus requires also looking at the association between board size and firm outcomes indicative of monitoring or efficiencies, respectively. ${ }^{3}$ We can, nevertheless, formulate more direct expectations for the effect in different firm types, as previous studies have shown that certain firm characteristics determine the usefulness of additional directors for firm monitoring (e.g., Boone et al., 2007; Coles et al., 2008; Linck et al., 2008). The trade-off between increasing the monitoring capacity, and increasing inefficiencies is related to the need for additional, more varied expertise on the board. This is why, in addition to using the overall sample of firms, we also conduct our analyses for two distinct firm types. Based on the monitoring hypothesis by Boone et al. (2007), we select one type where we expect monitoring capacity reasons, and one where we expect inefficiency reasons to explain the association between board size and risk.

First, we analyze complex firms, defined according to size, scope of operations, and leverage (Coles et al., 2008), which have a greater need for specialized knowledge in different areas and therefore, tend to have larger boards. They require different types of expertise, and, when these firms have more directors, they actually perform better (Coles et al., 2008; Adams and Mehran, 2012), which is compatible with the result in Weber (2006). That is why we expect the association to be negative and the outcome of a positive development as it will indicate a reduction in unnecessary risks. How the reduction will compare to that in non-complex firms is difficult to predict. These firms may also experience a monitoring effect from adding directors to the board, which will probably dissipate quickly and might even turn into an inefficiency effect. Whether the negative association in non-complex firms is stronger, weaker, or of comparable magnitude cannot be gleaned from the theoretical or empirical papers. Regarding the monitoring outcomes, we expect larger boards to be associated with better monitoring in complex firms. ${ }^{4}$ In other words, we expect the monitoring capacity explanation to be the main driver of the volatility reduction in complex firms. ${ }^{5}$

\footnotetext{
${ }^{3}$ We will explain our proxies for each in Section 3.5.

${ }^{4}$ Note that evidence of strong monitoring does not necessarily imply a strong volatility reduction. It only indicates that better monitoring is the likely reason for the volatility reduction.

${ }^{5}$ To our knowledge, the only study that investigates the relation between board size and a dimension of risk in complex firms, is that by Darrat et al. (2016). They show that such firms are less likely to end up in bankruptcy if they have larger boards.
} 
Second, we examine high-growth firms, defined by R\&D expenditures ${ }^{6}$, which have very high monitoring costs (Jensen, 1993), and so they tend to have smaller boards (Linck et al., 2008; Lehn et al., 2009). Formal models by, for instance, Raheja (2005) and Harris and Raviv (2008) support the notion that when monitoring is costly, large boards are more likely to be ineffective. Directors face high costs of acquiring knowledge about the firm. Thus, their job becomes more difficult and so does the coordination among board members, which causes inefficiencies. Moreover, high-growth firms do not necessarily require different types of expertise from a multitude of directors. Therefore, we expect these inefficiencies to manifest quickly at comparatively smaller board sizes in these firms, which will lead to a stronger reduction in volatility than in low-growth firms. With respect to the monitoring and efficiency proxies, however, we expect to find larger boards to be associated with greater inefficiency. That is, we believe the inefficiencies to be the main reason behind the volatility reduction in high-growth firms.

We test the two competing explanations on a sample of 2,230 U.S. firms for the period from 1996 to 2015. Our baseline regression results show that board size is associated with a statistically and economically significant reduction in firm risk, measured via the standard deviation of daily stock returns (i.e., the volatility), over all firms, which is compatible with both the inefficiency and the monitoring capacity explanation. We do, however, find differential results for the two firm types. While board size in complex firms has no additional effect compared to non-complex firms, it reduces the volatility of high-growth firms significantly faster than it does for low-growth firms. This finding is compatible with the idea that larger boards can accomplish better monitoring in complex firms, yet quickly lead to inefficiencies in high-growth firms, which we will further corroborate with the monitoring and efficiency tests.

In accordance with prior literature, we use the natural logarithm of board size in our baseline analyses, which accounts for the non-linear relationship. To get a better understanding of the specific effects of different board sizes, we rerun the regressions with board size dummies representing different size categories. These are based on quartiles of the actual distributions of board sizes in our sample, with the small dummy covering boards from 4 to 8 directors, the medium dummy covering boards with 9 to 11 directors, and the large dummy covering boards with 12 to 22 directors. ${ }^{7}$ Our results from the baseline regressions are confirmed, showing that

\footnotetext{
${ }^{6}$ Using R\&D expenditures means our firm types are identical to the ones used in Coles et al. (2008). In the robustness section, we verify the results by using the market-to-book ratio.

${ }^{7}$ We take the two middle quartiles together as the medium category, so that the small and large categories represent the extremes of our sample.
} 
increases in board size reduce the stock return volatility. While we, again, see no significant effect of board size between non-complex and complex firms, we do find one for high-growth firms, where medium boards reduce the volatility to a much greater degree than for low-growth firms. For large boards, the effect is again indistinguishable, supporting our expectation that the magnitude of the effect is already realized at medium-sized boards. In other words, the effect sets in fully sooner in high-growth firms, which is in line with the conjecture of inefficiencies in this firm type.

As an additional test, we replace the overall volatility with the idiosyncratic volatility, calculated from the residuals of Fama-French three-factor model estimations. Overall volatility may be driven by market-wide factors that are beyond the influence of internal governance mechanisms, which is why the idiosyncratic volatility may be more informative about the effect of the board of directors. We repeat our baseline regressions and the results remain unchanged. For other sensitivity tests, we define high-growth firms according to the market-to-book ratio; add dual-class firms back into the sample; use six instead of three size categories; include additional control variables (e.g., compensation vega or board co-option); and, we replace some of our control variables with alternative proxies. The association of board size and firm risk remains robust, including for the two different firm types.

Despite all of these robustness checks, there remains a possibility of endogeneity, which we address with two separate approaches. First, we use two-stage least squares (2SLS) regressions to address both simultaneity and omitted variable concerns. In accordance with several recent studies $^{8}$, we use industry-level measures to predict our potentially endogenous variable board size and relate it to the idiosyncratic volatility. Since industry-level board size is highly unlikely to affect a particular firm's idiosyncratic volatility, this approach should satisfy the exclusion condition. At the same time, the test statistics underscore the relevance of the instrument, which gives us confidence in this approach. The results support our baseline findings. Second, we employ a generalized method of moments (GMM) approach according to Wintoki et al. (2012). This procedure allows for a dynamic relation between board size and volatility, meaning that board size could affect volatility, but could also be affected by past volatility. Again, the results confirm our baseline findings for all firms and for the two firm types.

Next, we try to distinguish between our two explanations and investigate why exactly the risk

\footnotetext{
${ }^{8}$ See, for example, Lin et al. (2011), Lin et al. (2011), Yang and Zhao (2014), Liu et al. (2015), and Tran and Turkiela (2020).
} 
goes down for firms that increase their board sizes. To that end, we test the association of board size and two kinds of firm outcomes. The first set of outcomes is indicative of monitoring, such as forced CEO turnover sensitivity to performance (e.g., Guo and Masulis, 2015), earnings management (e.g., Xie et al., 2003), dividend payouts (e.g., Chen et al., 2017), and leverage (e.g., Arping and Sautner, 2010). The other one focuses directly on (in)efficiencies in the innovation process, which is particularly relevant for high-growth firms. For the monitoring outcomes across all firms, we find that larger boards are associated with lower abnormal accruals, a higher likelihood of dividend payments and larger payouts, as well as lower leverage. For complex firms, we find similar results with large boards being associated with higher payouts, a greater likelihood of payouts, and lower leverage than in non-complex firms. Additionally, large boards in complex firms are associated with a comparatively higher likelihood of forced CEO turnovers when firm performance is poor. They also appear to reduce incidences of earnings management when pre-managed earnings are lower than in the previous year, which is not the case in non-complex firms. For high-growth firms, conversely, we find that large boards are associated with greater abnormal accruals in those situations, while we find no additional effect on dividend payments or leverage beyond what exists for low-growth firms. Results support the monitoring explanation for complex firms, but not for high-growth firms.

To further substantiate the conjecture that larger boards lead to inefficiencies in high-growth firms, we investigate the association of board size and an area that is susceptible to inefficiencies, namely innovation. We use patent data from Kogan et al. (2017) for this test. While we find minimal to no effect over all firms and complex ones, which is not unexpected, the results for high-growth firms are highly significant. For those firms, the association of board size and the number, citations, and overall values of their patents is also positive. However, when putting the overall value of patents in relation to their R\&D expenditures, the association with board size is negative. Additionally, the value per patent also goes down by economically significant margins as board size increases. Essentially, while the quantitative output increases, the quality per patent decreases, which is strongly indicative of inefficiencies resulting from larger boards in high-growth firms.

Our results contribute to the literature in two ways. First, we contribute to the aspect of fast-growing literature that analyzes the relation between board characteristics and firm risk. Bernile et al. (2018), for example, show that firms with more diverse boards, measured on a broad index, have lower stock return volatility, because the differences in backgrounds lead to more compromises, which, in turn, leads to more persistence in firm policies and thus, lower firm 
risk. Tran and Turkiela (2020) show that when decision-making power is more concentrated on a few people on the board, firms tend to experience more volatility. With respect to board size, Cheng (2008) has previously shown that larger boards lead to a lower variability in corporate performance, claiming that coordination and cooperation problems are the underlying cause. Wang (2012) shows that this result holds when controlling for the effects of incentive-based pay. Neither study, however, investigates the possibility that the reduction could be caused by improved monitoring. We provide evidence that, overall, increases in board size are associated with better firm monitoring, which leads to lower abnormal accruals, a greater chance of dividend payments, higher dividend payouts, and lower leverage and thus to lower firm risk.

Second, we extend the literature that investigates firm-type-specific effects of corporate governance on firm outcomes. Research on the determinants of board composition has revealed that different firm types benefit from different board sizes (e.g., Boone et al., 2007; Linck et al., 2008). Most importantly, Coles et al. (2008) show that complex firms benefit from larger boards in terms of firm performance, while R\&D-intensive firms do not. Our paper is the first to analyze a firm-specific effect of board characteristics on firm risk. We show that increases in board size have different consequences for different firm types. In complex firms, our empirical evidence supports the notion that additional directors increase the monitoring capacity of the boards, which leads to a reduction in firm risk. In high-growth firms, smaller increases in board size reduce the volatility more strongly than in low-growth firms, and we do not find significant firm-specific effects on monitoring outcomes. Conversely, we find strong evidence that larger boards are associated with inefficiencies in the innovation process, as individual patents become less valuable and the overall value of all patents in relation to the $R \& D$ expenditures goes down as boards become larger.

The remainder of this paper is organized as follows. Section 3.2 contains a description of our data set and the firm type definitions, as well as the descriptive statistics. Our main results regarding the association of board size and firm risk are presented in Section 3.3, while Section 3.4 addresses endogeneity concerns. In Section 3.5 we investigate whether the reduction in firm risk is more like a result of increased monitoring capacities, or inefficiencies of large boards. Section 3.6 concludes the paper. 


\subsection{Data set and descriptive statistics}

\subsubsection{Data set}

We construct our sample beginning with all firms covered in the Institutional Shareholder Services (ISS) database (formerly RiskMetrics), from which we collect all board data, as well as data on external governance. Our sample begins in 1996, when most director-related data became available, and it ends in 2015. Following the literature, we exclude financial institutions (SIC codes 6000-6999) and all dual-class firms, whose corporate governance structures will likely differ significantly. ${ }^{9}$ As in Cheng (2008), we also exclude nine observations from seven firms that have a board size of three, which is likely a data error in the ISS database. We merge the data set with accounting and financial data from Compustat, and we obtain data on CEO ownership and tenure from ExecuComp. Daily stock returns are from the Center for Research in Security Prices (CRSP).

\subsubsection{Defining firm types}

We follow Coles et al. (2008) in identifying complex firms via a principal components analysis (PCA), in which we consider the scope of operations, firm size, and financial leverage as the three main complexity dimensions. We include one proxy for each of the dimensions in the PCA, namely, the number of business segments in different Fama-French 49 industries, the natural logarithm of sales, and book leverage. We then define a firm as complex when the factor score from the PCA of the particular firm-year is above the sample median.

High-growth firms have been defined by a variety of proxies in the literature. In our main analysis, we measure growth opportunities according to the ratio of $R \& D$ expenditures to the book value of assets, which makes our two firm types comparable to those used in Coles et al. (2008). In the robustness section, we also use the market-to-book ratio as an alternative and get very similar results. We define firms as high-growth firms when that ratio is above the 75 th percentile value. In accordance with prior literature (e.g., Coles et al., 2008; Bernile et al., 2018), we set missing values to zero. Notably, complexity and R\&D intensity appear to be very distinct firm traits, since they do not show much overlap throughout our sample. Of the 9,738 $(4,869)$ firm-year observations for complex (high-growth) firms, only 1,270 fall into both categories.

\footnotetext{
${ }^{9}$ In Section 3.3.3 we briefly explain the results of two robustness checks in which we include dual-class firms or exclude utilities, respectively. These tests generally confirm our results.
} 


\subsubsection{Variables and descriptive statistics}

Our main dependent variable of interest is stock return volatility, which we calculate as the annualized standard deviation of daily stock returns for every firm's fiscal year. In addition, we also calculate the idiosyncratic volatility as the standard deviation of the residuals from Fama-French three-factor model estimations and apply this as the dependent variable in an additional analysis presented in Section 3.3.2. ${ }^{10}$ Our main explanatory variable of interest is board size, for which we use both the natural log of the number of directors as well as board size categories based on the actual distribution in our sample. The latter approach allows us to analyze in which size category the effects occur. Table 3.1 provides an overview of the board size variables, including the categories, for all firms as well as for the different firm types.

Table 3.1: Board size overview

\begin{tabular}{llcccc}
\hline Panel A: Board Size Counter & & & \\
\cline { 2 - 3 } Board Size & Mean & All & 9.24 & Complex & High Growth \\
\cline { 2 - 3 } & Median & 9 & 10.27 & 8.38 \\
& Min. & 4 & 10 & 8 \\
& Max. & 22 & 4 & 4 \\
& Std. Dev. & 2.30 & & 22 & 19 \\
& & & 2.19 & 2.20 \\
\hline
\end{tabular}

\begin{tabular}{|c|c|c|c|c|c|c|c|}
\hline \multicolumn{8}{|c|}{ Panel B: Board Size Categories } \\
\hline & \multirow[b]{2}{*}{ Definition } & \multicolumn{2}{|r|}{ All } & \multicolumn{2}{|c|}{ Complex } & \multicolumn{2}{|c|}{ High Growth } \\
\hline & & Obs. & $\%$ of sample & Obs. & $\%$ of sample & Obs. & $\%$ of sample \\
\hline Small Board & $4-8$ & 7,632 & $39.2 \%$ & 1,928 & $9.9 \%$ & 2,791 & $14.3 \%$ \\
\hline Medium Board & $9-11$ & 8,752 & $44.9 \%$ & 5,225 & $26.8 \%$ & 1,627 & $8.4 \%$ \\
\hline \multirow[t]{2}{*}{ Large Board } & $12-22$ & 3,092 & $15.9 \%$ & 2,585 & $13.3 \%$ & 451 & $2.3 \%$ \\
\hline & & 19,476 & $100.0 \%$ & 9,738 & $50.0 \%$ & 4,869 & $25.0 \%$ \\
\hline
\end{tabular}

This table presents an overview of the distribution of board size. Panel A provides descriptive statistics for the board size variable that counts the number of directors on the board, while Panel B illustrates the definition as well as the distribution of the three board size categories that we define based on the empirical distribution of the number of directors on the board. In both panels the respective statistics are presented across all firms as well as for the two firm types, complex and high-growth firms.

The mean (median) board size is 9.24 (9), which makes this variable comparable to that observed by Cheng (2008). Consistent with prior literature, we see that complex firms have larger boards with a mean (median) of 10.27 (10), while high-growth firms have smaller boards with a mean (median) of 8.38 (8). To construct our board size dummy variables, we use the 25 th percentile, which is eight directors, and the 75th percentile, which is 11 , as the thresholds for the three categories small, medium, and large. We always sort firms that have exactly these values into the

\footnotetext{
${ }^{10} \mathrm{We}$ collect data for the model, including the risk-free rate, from Kenneth French's data library (http://mba.tuck.dartmouth.edu/pages/faculty/ken.french/data_library.html).
} 
lower category (i.e., firms with eight directors belong to the small board category). That is why the observations in the categories are not exactly equal to $25 \%, 50 \%$, and $25 \%$. Rather, $15.9 \%$ of all observations fall into the large board category, while $44.9 \%$ count as medium boards, and $39.2 \%$ are small boards. ${ }^{11}$ The fact that a board size of eight directors is the threshold between small and medium boards is very telling, as Jensen (1993) argues that problems start to set in when boards go beyond that value in terms of their size.

In our models, we also control for several other board and CEO characteristics that we expect to be related to stock return volatility, such as board independence, CEO-chair duality, CEO tenure, and CEO ownership. In addition, we control for external governance by using the entrenchment index (E index) of Bebchuk et al. (2009). As firm controls, we include measures for firm size, book leverage, operating performance, cash holdings, R\&D expenditures, and growth opportunities, which we measure as capital expenditures over sales, unless these variables are used to identify the firm type. All of the inputs are obtained from Compustat. Finally, we control for firm age based on the date when the trading data first became available in the CRSP database. An overview of our variables, including definitions and databases, can be found in Table B.1 in Appendix B. Table 3.2 provides summary statistics for the volatility measures, as well as for governance and firm characteristics.

\footnotetext{
${ }^{11}$ Of the two extreme board size categories, the small board category comprises a considerably larger number of observations. One reason for this is there are 2,973 firm-year observations ( $15.3 \%$ of our sample) with a board size of eight, which lie directly on the threshold with the medium category. In Section 3.3.3, we address this issue and classify boards of eight directors as medium sized. Our results remain qualitatively the same.
} 
Table 3.2: Summary statistics

\begin{tabular}{|c|c|c|c|c|c|c|c|c|}
\hline & Obs. & Mean & Std. Dev. & Min. & 25th Pct. & Median & 75th Pct. & Max. \\
\hline \multicolumn{9}{|l|}{ Volatility Measures } \\
\hline Volatility (\%) & 19476 & 40.376 & 20.214 & 7.317 & 26.479 & 35.548 & 48.927 & 224.052 \\
\hline Idiosyncratic Volatility (\%) & 19476 & 33.583 & 17.942 & 6.938 & 21.376 & 29.370 & 40.918 & 219.554 \\
\hline \multicolumn{9}{|l|}{ Board Governance \& $C E O$} \\
\hline Board Size & 19476 & 9.243 & 2.297 & 4.000 & 8.000 & 9.000 & 11.000 & 22.000 \\
\hline Independence (\%) & 19476 & 73.473 & 15.490 & 0.000 & 66.667 & 77.778 & 85.714 & 100.000 \\
\hline CEO Duality & 19476 & 0.577 & 0.494 & 0.000 & 0.000 & 1.000 & 1.000 & 1.000 \\
\hline CEO Tenure & 19476 & 7.649 & 7.113 & 0.000 & 3.000 & 6.000 & 10.000 & 62.000 \\
\hline CEO Ownership (\%) & 19476 & 1.552 & 4.573 & 0.000 & 0.000 & 0.144 & 0.850 & 66.601 \\
\hline \multicolumn{9}{|l|}{ External Governance } \\
\hline E Index & 19476 & 3.093 & 1.430 & 0.000 & 2.000 & 3.000 & 4.000 & 6.000 \\
\hline \multicolumn{9}{|l|}{ Further Controls } \\
\hline Total Assets & 19476 & 7640.877 & 20138.949 & 6.268 & 712.995 & 1911.599 & 6063.991 & 479921.000 \\
\hline Book Leverage (\%) & 19476 & 23.298 & 18.136 & 0.000 & 8.522 & 22.857 & 34.556 & 292.514 \\
\hline ROA (\%) & 19476 & 4.127 & 12.832 & -458.310 & 2.085 & 5.074 & 8.765 & 87.199 \\
\hline Cash/Assets (\%) & 19476 & 13.616 & 15.877 & -0.161 & 2.225 & 7.322 & 19.437 & 100.000 \\
\hline R\&D/Assets (\%) & 19476 & 2.952 & 5.637 & 0.000 & 0.000 & 0.000 & 3.697 & 112.910 \\
\hline CAPEX/Sales (\%) & 19476 & 9.852 & 168.919 & 0.000 & 2.289 & 4.052 & 8.146 & 23398.992 \\
\hline Firm Age & 19476 & 28.550 & 20.577 & 0.000 & 13.000 & 23.000 & 39.000 & 91.000 \\
\hline
\end{tabular}

This table shows summary statistics of the variables used throughout our analyses. The sample covers all firms in the ISS database from 1996 to 2015 . Financial firms (SIC codes 6000-6999) and dual-class firms are excluded. Data on daily stock returns, used to calculate stock return volatility and idiosyncratic volatility, are obtained from CRSP. Idiosyncratic volatility is based on residuals from Fama-French three-factor model estimations. All variables are defined in Table B.1 in Appendix B. 
For the 19,476 observations (2,230 firms) in our data set, it can be observed that the average volatility is $40.4 \%$ and that the idiosyncratic value is, expectedly, somewhat lower. Additionally, an upper quartile of $48.9 \%$ and a maximum of $224.1 \%$ already show that volatility is very high for some firms.

On average, the firms in our sample have boards that are $73.5 \%$ comprised of independent directors, and in $57.7 \%$ of the firm-year observations, the CEO is also the chairperson. Moreover, it can be observed that several variables exhibit extreme values. Firm size, as measured by total assets, ranges from $\$ 6$ million to $\$ 479.9$ billion, with a mean (median) of $\$ 7.64$ billion ( $\$ 1.91$ billion). Similar observations can be made for book leverage, the return on assets (ROA), cash holdings, R\&D expenditures, and our measure for growth opportunities. To alleviate concerns about these extreme values affecting our results, we winsorize these variables at the $1 \%$ and $99 \%$ levels.

\subsection{Board size and firm risk}

\subsubsection{Baseline regressions}

We start our empirical analysis by investigating the association of board size and volatility. Just as for all the analyses presented in the following, we do this once for the overall sample and for each of the two firm types separately. Our baseline model looks as follows:

$$
\begin{aligned}
& \text { Volatility }_{i, t}=\beta_{0}+\beta_{1} \operatorname{Ln}(\text { Board Size })_{i, t}
\end{aligned}
$$

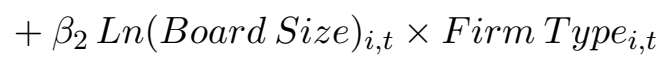

$$
\begin{aligned}
& +\beta_{3} \text { Firm Type }_{i, t}+\gamma \text { Controls }_{i, t}+\lambda_{j}+\phi_{t}+\epsilon_{i, t}
\end{aligned}
$$

where Volatility $_{i, t}$ is the overall stock return volatility. Firm Type $e_{i, t}$ is a dummy variable that indicates the two different firm types, and which is interacted with our board size variable. In the case where we analyze the overall sample, this dummy is zero so that the two respective terms drop out of the equation. Controls $s_{i, t}$ is a vector containing the control variables as described in the previous section, and defined in Table B.1 in Appendix B. Whenever we estimate models for the firm types, we exclude the control variables that are part of or closely related to the firm identifier. For example, when we analyze complex firms, we drop LN(Total Assets) and Book Leverage, since they are already part of the PCA to define the complex dummy. $\lambda_{j}$ and $\phi_{t}$ represent industry fixed effects, to control for unobserved heterogeneity in a firm's competitive environment, and time fixed effects. Throughout our estimations we always cluster standard 
errors at the firm level. Table 3.3 illustrates the results of the estimations of the model from Equation (3.1).

The highly statistically significant negative coefficient on board size in Column (1) shows that the finding from our sample comports with the ones previously reported by Cheng (2008), and supports our general prediction of a negative association. Additionally, the estimates for the control variables show the expected signs, with the exception of cash holdings. Based on the coefficient estimates, an increase in board size by one standard deviation (2.30) at the median (9 directors), would lead to a decrease in volatility by roughly 1.53 percentage points. As stated earlier, this result is compatible with both the inefficiency and the monitoring explanation and requires further analysis in Section 3.5.

In Column (2), we can see that the association between board size and volatility is not different for complex firms, when compared to their non-complex counterparts, as the interaction term is insignificant. Contrarily, we find that the negative association is much stronger for high-growth firms than for low-growth firms, as the interaction term is highly significant, both statistically and economically. While high-growth firms have a higher volatility on average, as one would expect, increases in board size lead to a faster reduction than in low-growth firms. This is also borne out by the coefficient estimates. In complex firms, increasing the median board with 10 directors by one standard deviation (2.19) is associated with a volatility reduction of 2.18 percentage points. For high-growth firms, the reduction amounts to 2.64 percentage points at a median board of 8 and a standard deviation of 2.20. In comparison, the same increase in board size would yield a volatility reduction of only 1.45 percentage points in low-growth firms.

The different findings for complex and high-growth firms serve as an initial indication that there is a difference in the association based on the firm type. Given that theoretical models predict that monitoring is costlier in high-growth firms, the results are in line with our supposition that the reduction in volatility might be due to inefficiencies in the decision-making process. Furthermore, the fact that volatility does not decline faster for larger boards in complex firms, than it does in non-complex firms, is also in line with the conjecture that these firms do not necessarily see large(r) reductions in risk for increases at smaller board sizes, but only realize the full monitoring effect at relatively large boards. We will investigate this further in Section 3.5.

Since these results provide an indication of the overall effect across the whole range of board sizes, we next investigate how the effect differs between different board size categories. This helps us to isolate in which size category the effect occurs the strongest, and whether the effect 
Table 3.3: Board size and volatility

\begin{tabular}{|c|c|c|c|}
\hline & 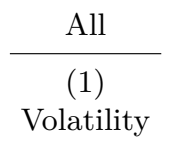 & $\begin{array}{c}\text { Complex } \\
(2) \\
\text { Volatility }\end{array}$ & $\begin{array}{c}\text { High Growth } \\
(3) \\
\text { Volatility }\end{array}$ \\
\hline Ln(Board Size) & $\begin{array}{c}-5.9790 * * * \\
(0.0000)\end{array}$ & $\begin{array}{c}-9.9490 * * * \\
(0.0000)\end{array}$ & $\begin{array}{c}-5.2740 * * * \\
(0.0000)\end{array}$ \\
\hline Ln $($ Board Size $) \times$ Firm Type & & $\begin{array}{l}-0.2703 \\
(0.8495)\end{array}$ & $\begin{array}{c}-4.3189 * * * \\
(0.0077)\end{array}$ \\
\hline Firm Type & & $\begin{array}{l}-1.7119 \\
(0.5888)\end{array}$ & $\begin{array}{c}11.8637^{* * *} \\
(0.0010)\end{array}$ \\
\hline Independence & $\begin{array}{c}-0.0355^{* * *} \\
(0.0048)\end{array}$ & $\begin{array}{c}-0.0388^{* * *} \\
(0.0024)\end{array}$ & $\begin{array}{c}-0.0376^{* * *} \\
(0.0030)\end{array}$ \\
\hline CEO Duality & $\begin{array}{c}0.1121 \\
(0.7373)\end{array}$ & $\begin{array}{l}-0.4523 \\
(0.1812)\end{array}$ & $\begin{array}{c}0.0734 \\
(0.8288)\end{array}$ \\
\hline Ln(1+CEO Tenure $)$ & $\begin{array}{l}-0.2873 \\
(0.1706)\end{array}$ & $\begin{array}{l}-0.1733 \\
(0.4157)\end{array}$ & $\begin{array}{l}-0.2773 \\
(0.1887)\end{array}$ \\
\hline CEO Ownership & $\begin{array}{l}-0.0463 \\
(0.2576)\end{array}$ & $\begin{array}{l}-0.0145 \\
(0.7324)\end{array}$ & $\begin{array}{l}-0.0441 \\
(0.2709)\end{array}$ \\
\hline E Index & $\begin{array}{c}-0.6208^{* * *} \\
(0.0000)\end{array}$ & $\begin{array}{c}-0.3708^{* *} \\
(0.0108)\end{array}$ & $\begin{array}{c}-0.6048^{* * *} \\
(0.0000)\end{array}$ \\
\hline Ln(Total Assets) & $\begin{array}{c}-2.2028^{* * *} \\
(0.0000)\end{array}$ & & $\begin{array}{l}-2.1542^{* * *} \\
(0.0000)\end{array}$ \\
\hline Book Leverage & $\begin{array}{c}0.0465^{* * *} \\
(0.0002)\end{array}$ & & $\begin{array}{c}0.0523^{* * *} \\
(0.0000)\end{array}$ \\
\hline ROA & $\begin{array}{c}-0.6625^{* * *} \\
(0.0000)\end{array}$ & $\begin{array}{c}-0.7105^{* * *} \\
(0.0000)\end{array}$ & $\begin{array}{c}-0.6758^{* * *} \\
(0.0000)\end{array}$ \\
\hline Cash/Assets & $\begin{array}{c}0.1370^{* * *} \\
(0.0000)\end{array}$ & $\begin{array}{c}0.1405^{* * *} \\
(0.0000)\end{array}$ & $\begin{array}{c}0.1293^{* * *} \\
(0.0000)\end{array}$ \\
\hline R\&D/Assets & $\begin{array}{c}0.2159^{* * *} \\
(0.0003)\end{array}$ & $\begin{array}{c}0.2059^{* * *} \\
(0.0006)\end{array}$ & \\
\hline CAPEX/Sales & $\begin{array}{c}0.1088^{* * *} \\
(0.0000)\end{array}$ & $\begin{array}{c}0.0937^{* * *} \\
(0.0000)\end{array}$ & \\
\hline Firm Age & $\begin{array}{c}-0.0662^{* * *} \\
(0.0000)\end{array}$ & $\begin{array}{c}-0.0899^{* * *} * \\
(0.0000)\end{array}$ & $\begin{array}{c}-0.0713^{* * *} \\
(0.0000)\end{array}$ \\
\hline Year Fixed Effects & Yes & Yes & Yes \\
\hline Industry Fixed Effects & Yes & Yes & Yes \\
\hline Sample Size & 19,476 & 19,476 & 19,476 \\
\hline Adj. R-Squared & 0.5790 & 0.5685 & 0.5770 \\
\hline
\end{tabular}

This table presents the results of regressions on the relation between the board size counter variable and volatility across all firms (Model (1)) as well as for the two firm types complex (Model (2)) and high-growth firms (Model (3)). In each model, the dependent variable is stock return volatility. Ln(Board Size) is the natural logarithm of the number of directors on the board. The firm type indicators are the dummy variables Complex, which is equal to one if the firm's complexity score is above the median, and High Growth, which is equal to one if the firm's ratio of $R \& D$ expenditures to assets is greater than the 75 th percentile. The remaining variables are defined in Table B.1 in Appendix B. All models include industry and year fixed effects, as well as a constant term. The $p$-values are based on standard errors clustered at the firm-level and are reported in parentheses. *, **, and *** indicate significance levels of $10 \%, 5 \%$, and $1 \%$, respectively. 
of a particular board category is distinct for one of the firm types. To that end, we separate firms into three groups, namely those with small, medium, and large boards. The categorization is based on the actual distribution of boards in our sample and has been detailed in Section 3.2. We replace our board size variable in Equation (3.1) by the medium and large category dummies, while the small category serves as the benchmark. We also interact these board categories with our firm type indicators so that the updated model looks as follows:

$$
\begin{aligned}
\text { Volatility }_{i, t}= & \beta_{0}+\beta_{1} \text { Medium Board }_{i, t}+\beta_{2} \text { Medium Board }_{i, t} \times \text { Firm Type }_{i, t} \\
& +\beta_{3} \text { Large Board }_{i, t}+\beta_{4} \text { Large Board }_{i, t} \times \text { Firm Type }_{i, t} \\
& +\beta_{5} \text { Firm Type }_{i, t}+\gamma \text { Controls }_{i, t}+\lambda_{j}+\phi_{t}+\epsilon_{i, t}
\end{aligned}
$$

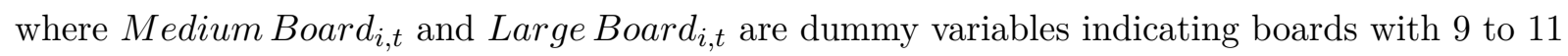
and 12 to 22 directors, respectively. The remaining variables are the same as in Equation (3.1). Table 3.4 presents the results of the estimations of the model from Equation (3.2).

First, for Models (1) and (2) the initial finding is confirmed: the larger the board is, the lower is the volatility. Over all firms, a move from a small board to a medium board is associated with a volatility reduction of 2.32 percentage points, while a move to a large board is related to a reduction of 3.54 percentage points. For complex firms in Column (2), we see that there is no significant difference of the board size effect between complex and non-complex firms, neither for medium nor for large boards. For high-growth firms in Column (3), on the other hand, we see that a move from a small to a medium board seems to reduce the volatility significantly faster than it does in low-growth firms. While for low-growth firms, a move to a medium-sized board is associated with a reduction in the volatility of 1.76 percentage points, high-growth firms experience almost twice that, as the total reduction amounts to 3.56 percentage points when the two coefficients are added up. For large boards, there is no significant difference between the two groups, and the total reduction in volatility is 3.07 percentage points, which is less than the reduction for medium boards in high-growth firms.

To investigate how significant this apparent increase in volatility is for large boards, we rerun Equation (3.1) with an included squared term of board size, which we interact with the highgrowth indicator. Both $L N($ Board Size $)$ and $L N(\text { Board Size })^{2}$ are insignificant, whereas the interaction terms with the high-growth indicator are highly statistically significant. However, the increase in volatility beyond the calculated minimum of 9.7 directors is hardly economically 
Table 3.4: Board size and volatility by board categories

\begin{tabular}{|c|c|c|c|}
\hline & All & Complex & High Growth \\
\hline & $\begin{array}{c}(1) \\
\text { Volatility }\end{array}$ & $\begin{array}{c}(2) \\
\text { Volatility }\end{array}$ & $\begin{array}{c}(3) \\
\text { Volatility }\end{array}$ \\
\hline Medium Board & $\begin{array}{c}-2.3163^{* * *} \\
(0.0000)\end{array}$ & $\begin{array}{c}-2.8340^{* * *} \\
(0.0000)\end{array}$ & $\begin{array}{c}-1.7638^{* * *} \\
(0.0000)\end{array}$ \\
\hline Medium Board $\times$ Firm Type & & $\begin{array}{l}-1.1619 \\
(0.1132)\end{array}$ & $\begin{array}{c}-1.7969^{* *} \\
(0.0267)\end{array}$ \\
\hline Large Board & $\begin{array}{c}-3.5422^{* * *} \\
(0.0000)\end{array}$ & $\begin{array}{c}-5.7278^{* * *} \\
(0.0000)\end{array}$ & $\begin{array}{c}-3.0697^{* * *} \\
(0.0000)\end{array}$ \\
\hline Large Board $\times$ Firm Type & & $\begin{array}{l}-0.4661 \\
(0.6797)\end{array}$ & $\begin{array}{l}-0.5465 \\
(0.6027)\end{array}$ \\
\hline Firm Type & & $\begin{array}{c}-1.7490 * * * \\
(0.0066)\end{array}$ & $\begin{array}{c}3.3814^{* * *} \\
(0.0000)\end{array}$ \\
\hline Independence & $\begin{array}{c}-0.0172 \\
(0.2419)\end{array}$ & $\begin{array}{c}-0.0253^{*} \\
(0.0791)\end{array}$ & $\begin{array}{c}-0.0402^{* * *} \\
(0.0016)\end{array}$ \\
\hline CEO Duality & $\begin{array}{c}0.0160 \\
(0.9630)\end{array}$ & $\begin{array}{l}-0.4104 \\
(0.2311)\end{array}$ & $\begin{array}{c}0.1586 \\
(0.6391)\end{array}$ \\
\hline Ln(1+CEO Tenure $)$ & $\begin{array}{c}-0.0032 \\
(0.9899)\end{array}$ & $\begin{array}{c}0.0522 \\
(0.8274)\end{array}$ & $\begin{array}{c}-0.2704 \\
(0.1966)\end{array}$ \\
\hline CEO Ownership & $\begin{array}{c}0.0073 \\
(0.8861)\end{array}$ & $\begin{array}{c}0.0350 \\
(0.4660)\end{array}$ & $\begin{array}{c}-0.0359 \\
(0.3628)\end{array}$ \\
\hline E Index & $\begin{array}{c}-0.4776^{* * *} \\
(0.0028)\end{array}$ & $\begin{array}{c}-0.3023^{* *} \\
(0.0451)\end{array}$ & $\begin{array}{c}-0.6348^{* * *} \\
(0.0000)\end{array}$ \\
\hline Ln(Total Assets) & $\begin{array}{c}-1.9646^{* * *} \\
(0.0000)\end{array}$ & & $\begin{array}{c}-2.3143^{* * *} \\
(0.0000)\end{array}$ \\
\hline Book Leverage & $\begin{array}{c}0.0511 * * * \\
(0.0001)\end{array}$ & & $\begin{array}{c}0.0533^{* * *} \\
(0.0000)\end{array}$ \\
\hline ROA & $\begin{array}{c}-0.6578^{* * *} \\
(0.0000)\end{array}$ & $\begin{array}{c}-0.7078^{* * *} \\
(0.0000)\end{array}$ & $\begin{array}{c}-0.6791^{* * *} \\
(0.0000)\end{array}$ \\
\hline Cash/Assets & $\begin{array}{c}0.1502^{* * *} \\
(0.0000)\end{array}$ & $\begin{array}{c}0.1520^{* * *} \\
(0.0000)\end{array}$ & $\begin{array}{c}0.1359^{* * *} \\
(0.0000)\end{array}$ \\
\hline R\&D/Assets & $\begin{array}{c}0.2489^{* * *} \\
(0.0001)\end{array}$ & $\begin{array}{c}0.2324^{* * *} \\
(0.0001)\end{array}$ & \\
\hline CAPEX/Sales & $\begin{array}{c}0.1130^{* * *} \\
(0.0000)\end{array}$ & $\begin{array}{c}0.0994^{* * *} \\
(0.0000)\end{array}$ & \\
\hline Firm Age & $\begin{array}{c}-0.0703^{* * *} \\
(0.0000)\end{array}$ & $\begin{array}{c}-0.0920^{* * *} \\
(0.0000)\end{array}$ & $\begin{array}{c}-0.0729^{* * *} \\
(0.0000)\end{array}$ \\
\hline Year Fixed Effects & Yes & Yes & Yes \\
\hline Industry Fixed Effects & Yes & Yes & Yes \\
\hline Sample Size & 19,476 & 19,476 & 19,476 \\
\hline Adj. R-Squared & 0.9137 & 0.9120 & 0.5758 \\
\hline
\end{tabular}

This table presents the results of regressions on the relation between our board size category variables and volatility across all firms (Model (1)) as well as for the two firm types complex (Model (2)) and high-growth firms (Model (3)). In each model, the dependent variable is stock return volatility. Medium Board is a dummy variable that is equal to one if the board size is between nine and 11, and Large Board is a dummy variable that is equal to one if the board size is between 12 and 22. The firm type indicators are the dummy variables Complex, which is equal to one if the firm's complexity score is above the median, and High Growth, which is equal to one if the firm's ratio of R\&D expenditures to assets is greater than the 75th percentile. The remaining variables are defined in Table B.1 in Appendix B. All models include industry and year fixed effects, as well as a constant term. The $p$-values are based on standard errors clustered at the firm-level and are reported in parentheses. $*, * *$, and $* * *$ indicate significance levels of $10 \%, 5 \%$, and $1 \%$, respectively. 
meaningful. ${ }^{12}$ Moreover, the adjusted $R^{2}$ is nearly identical to that of Model (3) in Table 3.3, suggesting that this approach does not model the relation any better than our baseline model does. Therefore, the combined evidence from the model with the squared term and the dummy variables suggests that there is no distinct economic meaningful difference in the effect of large boards in high-growth and low-growth firms.

Taken together, the results from the tests with the board size categories suggest two things. First, the overall negative association between board size and firm risk is supported. Second, we again see that for the two firm types, the effect of board size is different. We see no added decrease in firm risk in complex firms, at either medium or large boards, compared to non-complex firms. For high-growth firms, on the other hand, the reduction is amplified for medium-sized boards, but not large boards. This is in line with our inefficiency prediction for this firm type, which says that the effect would manifest at comparatively smaller boards. We will provide further evidence in support of this interpretation in Section 3.5.

\subsubsection{Idiosyncratic firm risk}

The analyses so far have relied on the overall volatility, which, potentially, might be driven to a large extent by influences outside managerial control. In that case, board structure may only have a small effect on it, or no effect at all. Idiosyncratic volatility, on the other hand, may be more informative about a firm's actions and thus be of interest when we analyze the effects of board size on volatility. As pointed out in Section 3.2.3, we calculate the idiosyncratic volatility as the standard deviation of the residuals from Fama-French three-factor model estimations. Results for the board size counter variable are depicted in Panel A, and for the size categories in Panel B of Table 3.5. Control variables are included but not reported for brevity.

In general, these regressions confirm our previous findings. The only notable difference compared to the results for overall volatility, is that complex firms exhibit lower idiosyncratic volatility than non-complex ones at medium boards, which is significant at the ten percent level. Since the idiosyncratic volatility is still lower, but not different to that of non-complex firms when they have large boards, this result is in line with our expectations.

Thus, our first set of analyses confirms previous results for all firms (i.e., larger boards are associated with lower volatility), but also establishes that the effect depends on the type of firm.

\footnotetext{
${ }^{12} \mathrm{~A}$ move from 10 to 12 directors is associated with an increase in volatility of about half a percentage point. Detailed results from the quadratic regression are available upon request.
} 
Table 3.5: Board size and idiosyncratic volatility

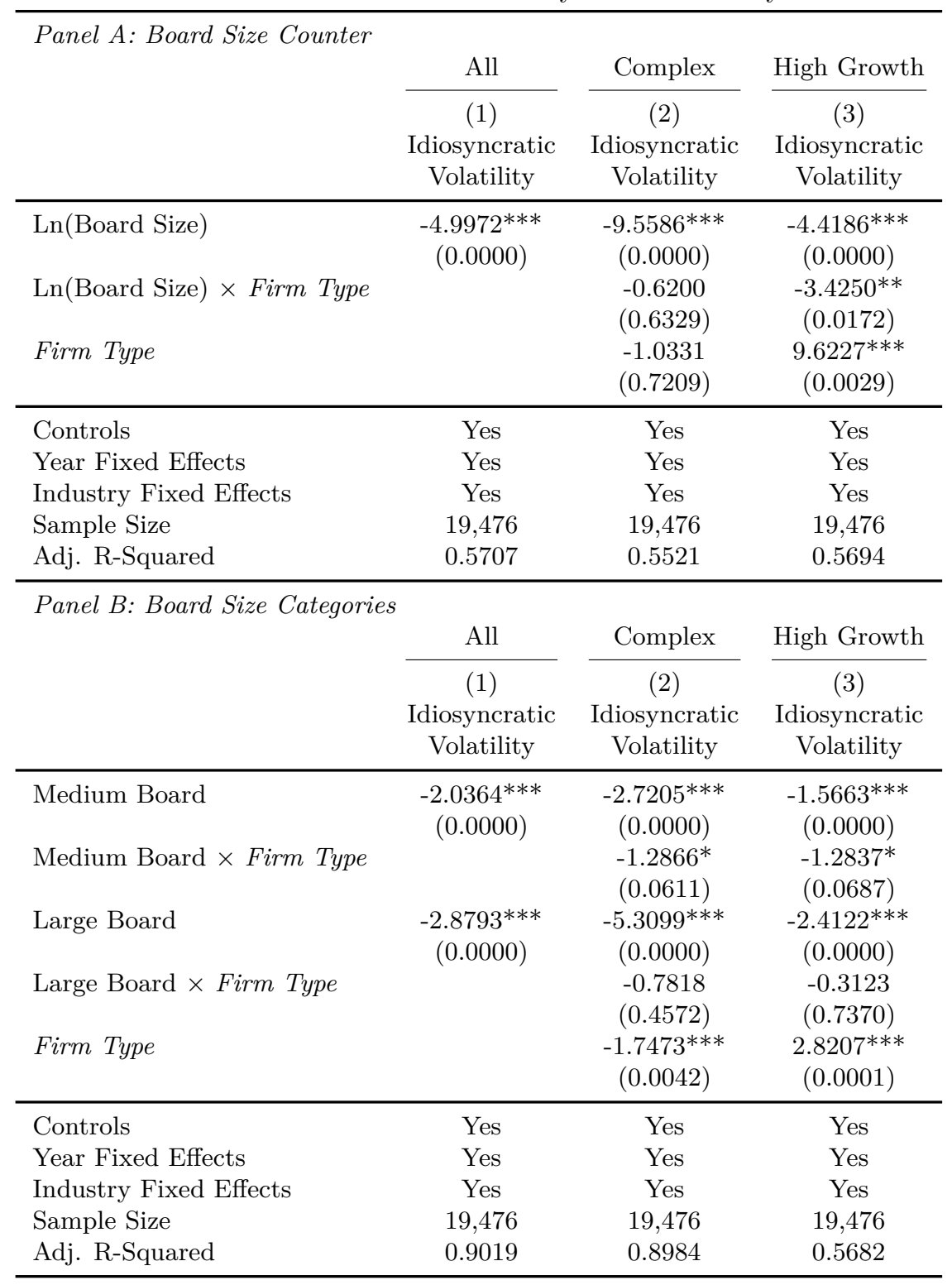

This table presents the results of regressions on the relation between board size and idiosyncratic volatility across all firms (Model (1)) as well as for the two firm types complex (Model (2)) and high-growth firms (Model (3)). Panel A includes the board size counter variable, whereas in Panel B board size is measured in categories. In each model, the dependent variable is idiosyncratic volatility, which is based on Fama-French three-factor model estimations. The firm type indicators are the dummy variables Complex, which is equal to one if the firm's complexity score is above the median, and High Growth, which is equal to one if the firm's ratio of R\&D expenditures to assets is greater than the 75th percentile. The (omitted) controls are the same as in previous analyses. Variable definitions can be found in Table B.1 in Appendix B. All models include industry and year fixed effects, as well as a constant term. The $p$-values are based on standard errors clustered at the firm-level and are reported in parentheses. *, **, and $* * *$ indicate significance levels of $10 \%, 5 \%$, and $1 \%$, respectively.. 
Our results show that larger boards reduce the volatility faster in high-growth than in low-growth firms, while in complex firms there is no discernible effect beyond what can already be observed for non-complex firms. To analyze whether the effects stem from monitoring or inefficiencies, we will investigate monitoring and efficiency outcomes in Section 3.5.

\subsubsection{Robustness checks}

To further corroborate our findings for the association between board size and volatility, we conduct the following tests. ${ }^{13}$ First, we re-estimate our models with dual-class firms, which we have previously excluded. This increases the sample size to 21,209 observations, yet the results of our main analysis remain unchanged.

Second, in addition to the financial firms that we exclude in our main analyses, we now also exclude utilities (SIC codes 4900-4999) from the sample, because they operate in regulated industries. This reduces the sample size to 17,836 observations. While the results for the board size counter models remain basically unchanged, the ones for the board size categories exhibit one notable difference to the baseline results, that is that complex firms show significantly lower volatility than non-complex firms when they have a medium board. Since complex firms still appear to have the lowest volatility when they have large boards, our inferences remain unchanged.

Third, since there is a debate in the literature about what the best proxy for growth opportunities is (e.g, Adam and Goyal, 2008), we use the market-to-book ratio to define high-growth firms and rerun our regressions. In doing so, we confirm our baseline results.

Fourth, risk-taking incentives provided to the CEO have been shown to drive firm risk (Coles et al., 2006). Therefore, we rerun our analyses, but including the sensitivity of CEO wealth to stock return volatility (vega) as a further control variable. At the same time we also include board co-option, as it has been shown to affect how well board members work together (Coles et al., 2014). ${ }^{14}$ Again, the results are virtually unchanged.

Fifth, even though we base the definition of our board size categories on the empirical distribution of board size, it still remains a discretionary choice to, for example, sort the observations that

\footnotetext{
${ }^{13}$ Results, when untabulated, are available upon request from the authors.

${ }^{14}$ We thank Lalitha Naveen for providing the data on vega and co-option online. However, since those data end in 2014 and are not available for all of firm-years in our sample, which would reduce the sample size by about 2,900 observations, we only include those two variables in this robustness check.
} 
fall directly on the thresholds ( 8 or 11 directors, respectively) into the respective lower category. That is why we also test alternative specifications, three of which we discuss here. (i) We sort observations with a board size of eight into the medium board category, which affects a total of 2,973 observations ( $15.3 \%$ of the sample). This creates a much more extreme benchmark group of small boards, which is reflected in generally higher coefficient estimates for the different board size variables. The complex dummy becomes insignificant, which is most likely due to the fact that we have a lot fewer observations of complex firms in the benchmark group so that the 'complexity effect' is fully absorbed in the interaction terms. Compared to the new extreme small-board group, complex firms on average exhibit an additional negative effect for medium boards, but large boards still provide the greatest volatility reduction in these firms, which is in line with our expectations. The models for the overall sample and for high-growth firms also confirm our earlier findings. (ii) We include boards with 11 directors (2,309 observations or $11,9 \%$ of the sample) into the large category. This generates a less extreme large group, which consequently results in slightly smaller coefficient estimates for medium and large boards. Except for that, our results are confirmed. (iii) We re-estimate our models including more granular board categories, that is, we include separate dummy variables for each of the most prevalent board sizes ( 8 to 11) of our sample and one for boards with more than 11 directors. This analysis reveals each board size's average difference in volatility compared to small boards of four to seven directors. Thus, it provides an indication of the average effect each additional director adds. Table 3.6 presents the estimations.

The results generally confirm the negative board size-volatility relation and provide further support for the fact that adding an additional director does not have the same effect across all board sizes. For example, increasing the board size from eight to nine directors is associated with a larger reduction in volatility than an increase from 10 to 11 . Moreover, results confirm our finding that the volatility reduction sets in at comparatively lower board sizes for high-growth firms, and that complex firms do not seem to be affected differently compared to non-complex ones.

Lastly, we replace some of our variables with alternative proxies. For example, we include Market Leverage, which is measured as the ratio of total debt to the market value of assets, instead of Book Leverage, and we replace our measure for growth opportunities, CAPEX/Sales, with the Market-to-Book ratio. The results are essentially unchanged.

We also perform all of these robustness checks for the idiosyncratic volatility and basically find 
Table 3.6: Board size and volatility by six board size categories

\begin{tabular}{|c|c|c|c|}
\hline & 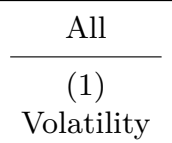 & $\begin{array}{c}\text { Complex } \\
(2) \\
\text { Volatility }\end{array}$ & $\begin{array}{c}\text { High Growth } \\
(3) \\
\text { Volatility }\end{array}$ \\
\hline Board Size $=8$ & $\begin{array}{c}-1.4874^{* * *} \\
(0.0010)\end{array}$ & $\begin{array}{c}-2.1290 * * * \\
(0.0000)\end{array}$ & $\begin{array}{l}-0.6597 \\
(0.2254)\end{array}$ \\
\hline Board Size $=8 \times$ Firm Type & & $\begin{array}{l}-0.6104 \\
(0.5202)\end{array}$ & $\begin{array}{c}-2.5690^{* * *} * \\
(0.0074)\end{array}$ \\
\hline Board Size $=9$ & $\begin{array}{c}-2.5922^{* * *} \\
(0.0000)\end{array}$ & $\begin{array}{c}-3.2701^{* * *} \\
(0.0000)\end{array}$ & $\begin{array}{c}-1.8735^{* * *} \\
(0.0006)\end{array}$ \\
\hline Board Size $=9 \times$ Firm Type & & $\begin{array}{l}-1.1993 \\
(0.2139)\end{array}$ & $\begin{array}{c}-2.7942^{* * *} \\
(0.0085)\end{array}$ \\
\hline Board Size $=10$ & $\begin{array}{c}-2.8510^{* * *} \\
(0.0000)\end{array}$ & $\begin{array}{c}-4.5313^{* * *} \\
(0.0000)\end{array}$ & $\begin{array}{c}-2.2061^{* * * *} \\
(0.0003)\end{array}$ \\
\hline Board Size $=10 \times$ Firm Type & & $\begin{array}{l}-0.7344 \\
(0.4812)\end{array}$ & $\begin{array}{c}-3.0760^{* *} \\
(0.0112)\end{array}$ \\
\hline Board Size $=11$ & $\begin{array}{c}-2.9991^{* * *} \\
(0.0000)\end{array}$ & $\begin{array}{c}-4.6713^{* * *} \\
(0.0000)\end{array}$ & $\begin{array}{c}-2.5560^{* * *} \\
(0.0000)\end{array}$ \\
\hline Board Size $=11 \times$ Firm Type & & $\begin{array}{l}-1.3888 \\
(0.2095)\end{array}$ & $\begin{array}{l}-1.7095 \\
(0.1775)\end{array}$ \\
\hline Board Size $>11$ & $\begin{array}{c}-3.8950 * * * \\
(0.0000)\end{array}$ & $\begin{array}{c}-7.1335^{* * *} \\
(0.0000)\end{array}$ & $\begin{array}{c}-3.5465^{* * *} \\
(0.0000)\end{array}$ \\
\hline Board Size $>11 \times$ Firm Type & & $\begin{array}{l}-0.4104 \\
(0.7321)\end{array}$ & $\begin{array}{l}-1.4137 \\
(0.2230)\end{array}$ \\
\hline Firm Type & & $\begin{array}{c}-1.6312^{* *} \\
(0.0432)\end{array}$ & $\begin{array}{c}4.2434^{* * * *} \\
(0.0000)\end{array}$ \\
\hline Controls & Yes & Yes & Yes \\
\hline Year Fixed Effects & Yes & Yes & Yes \\
\hline Industry Fixed Effects & Yes & Yes & Yes \\
\hline Sample Size & 19,476 & 19,476 & 19,476 \\
\hline Adj. R-Squared & 0.5784 & 0.5673 & 0.5765 \\
\hline
\end{tabular}

This table presents the results of the regressions on the relation between board size and volatility, where board size is measured by six categories. In each model the dependent variable is stock return volatility. Small Board, Medium Small Board, Medium Large Board, Large Board are dummy variables that are equal to one if the board size is eight, nine, ten, or 11, respectively, and Extra Large Board is a dummy variable that is equal to one if board size is between 12 and 22. The firm type indicators are the dummy variables Complex, which is equal to one if the firm's complexity score is above the median, and High Growth, which is equal to one if the firm's ratio of R\&D expenditures to assets is greater than the 75 th percentile. The (omitted) controls are the same as in previous analyses. Variable definitions can be found in Table B.1 in Appendix B. All models include industry and year fixed effects, as well as a constant term. The $p$-values are based on standard errors clustered at the firm-level and are reported in parentheses. ${ }^{*}, * *$, and ${ }^{* * *}$ indicate significance levels of $10 \%, 5 \%$, and $1 \%$, respectively. 
results that confirm the ones presented in Section 3.3.2. The only exception is that in a few tests the firm-specific effect of medium boards in high-growth firms does not hold on a ten percent level anymore.

In total, the robustness checks presented in this section predominantly confirm our earlier findings, so we remain confident that our results are not driven by some discretionary choices made during the analyses.

\subsection{Endogeneity concerns}

As in most empirical corporate finance studies, endogeneity concerns play a role when examining the relation between board size and stock return volatility. To the best of our knowledge, no generally accepted fully exogenous approach, such as a natural experiment, exists for board size studies. Nakano and Nguyen (2012), who focus on Japanese firms, use the percentage of a firm's free float as an instrument for board size. However, when we do the same with our U.S. sample, the first-stage test statistics reveal free float to be a weak instrument. Besides including industry fixed effects in our models to control for unobserved heterogeneity, we rely on two approaches that have been used in the literature to mitigate these concerns.

\subsubsection{Two-stage least squares estimation}

First, we conduct two-stage least squares (2SLS) estimations that address both simultaneity and omitted variable concerns. We follow a number of recent studies that use industry-level measures of their potentially endogenous variable of interest as the instrument. ${ }^{15} \mathrm{~A}$ firm's competitive environment, such as levels of information asymmetry, will likely influence its choice of board structure, including the size of the board (e.g., Boone et al., 2007; Lehn et al., 2009). Therefore, it stands to reason that the median industry-level board size will be highly correlated with the firm's board size. At the same time, it is highly unlikely that the industry median board structure will affect any particular firm's idiosyncratic volatility. In other words, industry board size should only affect firm-level idiosyncratic volatility through its effect on the firm's board size, which satisfies the exclusion restriction.

We begin by identifying the industry median of board size for each year and use it as the instrument for the firm-level board size in the first-stage regression. For the estimations by

\footnotetext{
${ }^{15}$ See, for example, Lin et al. (2011), Lin et al. (2011), Kim et al. (2014), Yang and Zhao (2014), Liu et al. (2015), and Tran and Turkiela (2020).
} 
firm type, the industry median board size is also interacted with our firm type dummies in the first stage to provide instruments for the respective interaction terms in the second stage. The predicted values are then used in the second stage to re-estimate our main models. Likewise, we also conduct 2SLS estimations for the board category models. In those cases, we instrument each board category by their industry mean of the particular year. Since our categories are defined as dummy variables, the instruments represent the fraction of firms in the same industry that have boards in the respective category.

Panel A of Table 3.7 illustrates two examples of the first-stage results for the cases without firm type differentiation and for high growth firms. The model for complex firms is estimated accordingly. The highly significant first-stage F-statistics of the excluded instruments and the highly significant coefficient estimates of the industry median (mean) board size variables and interaction terms indicate that we do not face a weak instrument problem. This also holds for all other untabulated first-stage regressions and provides support for the relevance of our instrument choice.

Table 3.7: Endogeneity - 2SLS

\begin{tabular}{|c|c|c|c|}
\hline \multirow[t]{2}{*}{ Panel A: Exemplary First Stage } & All Firms & \multicolumn{2}{|c|}{ High Growth Firms } \\
\hline & $\begin{array}{c}(1) \\
\operatorname{Ln}(\text { Board Size })\end{array}$ & $\begin{array}{c}(2) \\
\operatorname{Ln}(\text { Board Size })\end{array}$ & $\begin{array}{c}(3) \\
\text { Ln(Board Size) } \\
\text { x High Growth }\end{array}$ \\
\hline Ln(Industry Board Size) & $\begin{array}{c}0.4125^{* * *} \\
(0.0000)\end{array}$ & $\begin{array}{c}0.4044^{* * *} \\
(0.0000)\end{array}$ & $\begin{array}{c}-0.0446^{* *} \\
(0.0421)\end{array}$ \\
\hline Ln(Industry Board Size $) \times$ High Growth & & $\begin{array}{l}0.0550 \\
(0.4269)\end{array}$ & $\begin{array}{c}0.6670^{* * *} \\
(0.0000)\end{array}$ \\
\hline High Growth & & $\begin{array}{l}-0.1138 \\
(0.4458)\end{array}$ & $\begin{array}{c}0.7094^{* * *} \\
(0.0000)\end{array}$ \\
\hline Controls & Yes & Yes & Yes \\
\hline Year Fixed Effects & Yes & Yes & Yes \\
\hline Industry Fixed Effects & Yes & Yes & Yes \\
\hline Sample Size & 19,476 & 19,476 & 19,476 \\
\hline Adj. R-Squared & 0.4560 & 0.4544 & 0.9850 \\
\hline F-Test of Excl. Instruments ( $p$-value) & 0.0000 & 0.0000 & 0.0000 \\
\hline \multicolumn{4}{|l|}{ Panel B: Board Size Counter (Second Stage) } \\
\hline & All & Complex & High Growth \\
\hline & $(1)$ & $(2)$ & $(3)$ \\
\hline & Idiosyncratic & Idiosyncratic & Idiosyncratic \\
\hline & Volatility & Volatility & Volatility \\
\hline Instr. Ln(Board Size) & $-38.4429 * * *$ & $-42.2880^{* * *}$ & $-30.2894^{* * *}$ \\
\hline Inctr In (Beard Size $) \times$ Firm Tume & $(0.0000)$ & $(0.0000)$ & $(0.0000)$ \\
\hline Instr. Ln(Board Size) $\times$ Firm Type & & $\begin{array}{c}8.3215 \\
(0.1827)\end{array}$ & $\begin{array}{c}-27.1374^{* * *} \\
(0.0002)\end{array}$ \\
\hline Firm Type & & -16.9169 & $60.6003^{* * *}$ \\
\hline
\end{tabular}


Table 3.7 Continued

\begin{tabular}{|c|c|c|c|}
\hline & & $(0.2255)$ & $(0.0001)$ \\
\hline Controls & Yes & Yes & Yes \\
\hline Year Fixed Effects & Yes & Yes & Yes \\
\hline Industry Fixed Effects & Yes & Yes & Yes \\
\hline Sample Size & 19,476 & 19,476 & 19,476 \\
\hline Adj. R-Squared & 0.4484 & 0.4444 & 0.4383 \\
\hline \multicolumn{4}{|c|}{ Panel C: Board Size Categories (Second Stage) } \\
\hline & All & Complex & High Growth \\
\hline & $(1)$ & $(2)$ & $(3)$ \\
\hline & Idiosyncratic & Idiosyncratic & Idiosyncratic \\
\hline & Volatility & Volatility & Volatility \\
\hline Instr. Medium Board & $\begin{array}{c}-12.3201^{* * *} \\
(0.0000)\end{array}$ & $\begin{array}{c}-13.9241^{* * *} \\
(0.0000)\end{array}$ & $\begin{array}{c}-7.9842^{* * *} \\
(0.0000)\end{array}$ \\
\hline \multirow[t]{2}{*}{ Instr. Medium Board $\times$ Firm Type } & & 3.4385 & $-23.0713^{* * *}$ \\
\hline & & $(0.2565)$ & $(0.0000)$ \\
\hline \multirow[t]{2}{*}{ Instr. Large Board } & $-20.4158^{* * *}$ & $-22.8937 * * *$ & $-18.9520 * * *$ \\
\hline & $(0.0000)$ & $(0.0000)$ & $(0.0000)$ \\
\hline \multirow[t]{2}{*}{ Instr. Large Board $\times$ Firm Type } & & 3.8791 & $9.1848^{*}$ \\
\hline & & $(0.3944)$ & $(0.0771)$ \\
\hline \multirow[t]{2}{*}{ Firm Type } & & -1.9847 & $10.5491^{* * *}$ \\
\hline & & $(0.3221)$ & $(0.0000)$ \\
\hline Controls & Yes & Yes & Yes \\
\hline Year Fixed Effects & Yes & Yes & Yes \\
\hline Industry Fixed Effects & Yes & Yes & Yes \\
\hline Sample Size & 19,476 & 19,476 & 19,476 \\
\hline Adj. R-Squared & 0.4863 & 0.4758 & 0.4053 \\
\hline
\end{tabular}

This table presents the regression results for the 2SLS estimations using the industry median (mean) as instruments for our firm-level board size counter (category) variables. Panel A presents exemplary first-stage results across all firms and for high growth firms in which board size is measured as a counter variable. Panel B illustrates the second-stage results for the models including the board size counter variable and Panel $\mathrm{C}$ for those measuring board size in categories. The second-stage models are the same as in previous analyses, except the board variables and the interaction terms are based on their predicted values. The (omitted) controls are the same as in previous analyses. Variable definitions can be found in Table B.1 in Appendix B. All models include industry and year fixed effects, as well as a constant term. The $p$-values are based on standard errors clustered at the firm-level and are reported in parentheses. ${ }^{*}, * *$, and ${ }^{* * *}$ indicate significance levels of $10 \%, 5 \%$, and $1 \%$, respectively.

Panel B and C of Table 3.7 contain the results based on the board size counter and categorical variables, respectively. The results clearly support our earlier findings in that board size negatively affects volatility and that this effect is especially strong in high-growth firms, where medium boards lead to a significantly stronger reduction in volatility than in low-growth firms, while large boards do not. In an unreported analysis, we also conduct 2SLS regressions similar to the ones presented by Wang (2012), in which we use the second and third lags of our board variables as instruments. The results are largely the same. However, it is hard to argue that the lagged values of board size really meet the exclusion condition.

\subsubsection{Dynamic panel GMM estimation}

Second, we follow the methodology suggested by Wintoki et al. (2012) and re-estimate our models using the dynamic panel GMM estimator developed by Arellano and Bond (1991), Arellano and 
Bover (1995), and Blundell and Bond (1998) that addresses both unobserved heterogeneity and simultaneity. This approach considers that the relation between board size and volatility could be dynamic, that is, board size could not only affect volatility but could also be a consequence of past volatility. The estimation procedure comprises a "stacked" system of equations that uses past values of the endogenous variables as instruments.

Similar to Wintoki et al. (2012), we address concerns with respect to the serial correlation of the transient errors and only include every other year in this analysis. We also assume all independent variables to be endogenous, except Firm Age and the fixed effects. We then augment our models by including the first lagged value of stock return volatility as an additional independent variable. Second and third lagged values of the explanatory variables - including the board size variables - are then utilized as instruments in the estimation procedure.

To verify the validity of the approach, we provide the standard test statistics. Throughout the models presented in Table 3.8, the null hypothesis of the Hansen test of overidentification cannot be rejected at the ten percent level, which supports the validity of the instruments. Furthermore, the test statistics show that second-order serial correlation is not an issue.

The results presented in Table 3.8 reveal similar patterns as our baseline analyses. Across all firms, board size is still negatively associated with volatility. While complex firms do not differ in this regard from non-complex ones, the effect is again particularly strong in high-growth firms. In Model (3) of Panel A, the interaction term fully absorbs the negative effect. The fact that the coefficient on the non-interacted board size becomes insignificant in this model is one notable difference to earlier analyses. Furthermore, the results in Panel B provide additional support for our conjecture that in high-growth firms the reduction in volatility sets in at comparatively smaller board sizes already. Surprisingly, and different to the results in our main analysis, we find a positive coefficient on the interaction term between complex firms and medium boards. Overall, the tests in this section mitigate endogeneity concerns and corroborate our earlier findings.

\subsection{Testing the monitoring capacity and inefficiency explanations}

Even though we have some initial indication with the two firm types, the results of the association between board size and firm risk can, for the most part, be explained by both monitoring capacity and inefficiency reasons. To ascertain which is more likely to be the underlying cause, we focus on the relation between board size and several firm outcomes that are indicative of (i) monitoring 
Table 3.8: Endogeneity - Dynamic panel GMM estimation

\begin{tabular}{|c|c|c|c|}
\hline Panel A: Board Size Counter & $\begin{array}{c}(1) \\
\text { Volatility }\end{array}$ & $\begin{array}{c}(2) \\
\text { Volatility }\end{array}$ & $\begin{array}{c}(3) \\
\text { Volatility }\end{array}$ \\
\hline L.Volatility & $\begin{array}{c}0.2839 * * * \\
(0.0000)\end{array}$ & $\begin{array}{c}0.2769 * * * \\
(0.0000)\end{array}$ & $\begin{array}{c}0.2983^{* * *} \\
(0.0000)\end{array}$ \\
\hline $\operatorname{Ln}($ Board Size $)$ & $\begin{array}{c}-15.0985^{*} \\
(0.0881)\end{array}$ & $\begin{array}{c}-21.3047^{*} \\
(0.0805)\end{array}$ & $\begin{array}{c}5.4623 \\
(0.7132)\end{array}$ \\
\hline Ln $($ Board Size $) \times$ Firm Type & & $\begin{array}{l}15.1348 \\
(0.2777)\end{array}$ & $\begin{array}{c}-81.9448^{* *} \\
(0.0182)\end{array}$ \\
\hline Firm Type & & $\begin{array}{r}-33.3826 \\
(0.2779)\end{array}$ & $\begin{array}{c}181.6434^{* *} \\
(0.0197)\end{array}$ \\
\hline Controls & Yes & Yes & Yes \\
\hline Year Fixed Effects & Yes & Yes & Yes \\
\hline Industry Fixed Effects & Yes & Yes & Yes \\
\hline Sample Size & 7,472 & 7,472 & 7,472 \\
\hline Wald $\chi^{2}$ Statistic & 32192.61 & 5875.44 & 5188.80 \\
\hline Number of Instruments & 87 & 87 & 87 \\
\hline $\mathrm{AR}(1) p$-value & 0.0000 & 0.0000 & 0.0000 \\
\hline $\mathrm{AR}(2) p$-value & 0.5382 & 0.4525 & 0.1761 \\
\hline Hansen J Statistic ( $p$-value) & 0.3201 & 0.2456 & 0.1640 \\
\hline \multicolumn{4}{|c|}{ Panel B: Board Size Categories } \\
\hline & $\begin{array}{c}(1) \\
\text { Volatility }\end{array}$ & $\begin{array}{c}(2) \\
\text { Volatility }\end{array}$ & $\begin{array}{c}(3) \\
\text { Volatility }\end{array}$ \\
\hline L.Volatility & $\begin{array}{c}0.2968^{* * *} \\
(0.0000)\end{array}$ & $\begin{array}{c}0.2887^{* * *} \\
(0.0000)\end{array}$ & $\begin{array}{c}0.3131^{* * *} \\
(0.0000)\end{array}$ \\
\hline Medium Board & $\begin{array}{l}-4.7010 \\
(0.1755)\end{array}$ & $\begin{array}{c}-8.8319^{* *} \\
(0.0214)\end{array}$ & $\begin{array}{c}4.6290 \\
(0.3532)\end{array}$ \\
\hline Medium Board $\times$ Firm Type & & $\begin{array}{c}15.5389^{* *} \\
(0.0340)\end{array}$ & $\begin{array}{c}-36.3530^{* * *} \\
(0.0009)\end{array}$ \\
\hline Large Board & $\begin{array}{c}-8.5055^{* *} \\
(0.0304)\end{array}$ & $\begin{array}{l}-2.0658 \\
(0.7358)\end{array}$ & $\begin{array}{l}-0.7952 \\
(0.8783)\end{array}$ \\
\hline Large Board $\times$ Firm Type & & $\begin{array}{l}-0.0858 \\
(0.9927)\end{array}$ & $\begin{array}{c}-22.4652^{*} \\
(0.0753)\end{array}$ \\
\hline Firm Type & & $\begin{array}{l}-8.8383 \\
(0.1115)\end{array}$ & $\begin{array}{c}29.1142^{* *} \\
(0.0177)\end{array}$ \\
\hline Controls & Yes & Yes & Yes \\
\hline Year Fixed Effects & Yes & Yes & Yes \\
\hline Industry Fixed Effects & Yes & Yes & Yes \\
\hline Sample Size & 7,472 & 7,472 & 7,472 \\
\hline Wald $\chi^{2}$ Statistic & 5575.10 & 5789.18 & 24852.38 \\
\hline Number of Instruments & 90 & 92 & 92 \\
\hline $\mathrm{AR}(1) p$-value & 0.0000 & 0.0000 & 0.0000 \\
\hline $\operatorname{AR}(2) p$-value & 0.5196 & 0.4214 & 0.2802 \\
\hline Hansen J Statistic ( $p$-value) & 0.2557 & 0.3334 & 0.3540 \\
\hline
\end{tabular}

This table presents the regression results for the GMM estimations according to Wintoki et al. (2012). This analysis uses only the even years of the original sample. Panel A includes the board size counter variable, whereas in Panel B board size is measured in categories. Besides the respective board categories, the firm type dummies, and the relevant control variables, the models include the first lag of stock return volatility as an independent variable. The (omitted) controls are the same as in previous analyses. Variable definitions can be found in Table B.1 in Appendix B. All models include industry and year fixed effects, as well as a constant term. The estimations are performed using Stata's xtabond2 module, where we employ the collapse and robust options. The $p$-values are reported in parentheses. $* * *$, and $* * *$ indicating significance levels of $10 \%, 5 \%$, and $1 \%$, respectively. 
activities and (ii) innovation, which is highly susceptible to inefficiencies in corporate boards (e.g., Belloc, 2012; Balsmeier et al., 2017).

\subsubsection{Evidence of board monitoring}

We begin the analysis with firm outcomes that are commonly associated with better monitoring, namely forced CEO turnovers, earnings management, dividend payments, and leverage. The first is arguably the most important monitoring task a board has, and that is deciding when to fire or retain the CEO (Hermalin and Weisbach, 2003; Guo and Masulis, 2015; Jenter and Kanaan, 2015). If an increase in board size is associated with inefficiencies, one would not expect forced CEO turnover to be higher after poor performance, while that would be the case if board size is associated with better monitoring. We use data on forced CEO turnovers from Peters and Wagner (2014) and Jenter and Kanaan (2015) and investigate whether board size is related to the likelihood of the CEO being released, while conditioning on firm performance. ${ }^{16}$ The second indicator we use is earnings management. Board monitoring should reduce earnings management, leading to a more truthful reporting of firm performance (Xie et al., 2003; Peasnell et al., 2005). Our proxy for earnings management is Abnormal Accruals, which we estimate using the modified Jones (1991)-model according to Dechow et al. (1995). Since the incentive to manage earnings upwards is particularly high if the firm misses its earnings targets, we follow Peasnell et al. (2005) and also interact our board size categories with the dummy variable PME Below, which takes the value of one if pre-managed earnings (PME) are below last year's earnings. We use cash flows from operating activities as a proxy for pre-managed earnings (Peasnell et al., 2005). Next, we check if firms with large boards have a higher likelihood to pay dividends and if they pay higher dividends. Distributing cash to shareholders reduces the free-cash flow problem and results in firms being exposed to the scrutiny of financial markets when they acquire external financing (Easterbrook, 1984; Jiraporn et al., 2011; Chen et al., 2017). Finally, we investigate if board size can affect leverage, which in itself can be a monitoring tool that is often used when internal corporate governance is weak (Arping and Sautner, 2010; Jiraporn et al., 2012). So, if boards increase their monitoring, we expect leverage to go down.

We use Equation (3.1), but replace the dependent variable with the above-mentioned proxies for monitoring. Results for all firms are presented in Panel A, for complex firms in Panel B, and for high-growth firms in Panel $\mathrm{C}$ of Table 3.9. For brevity, we do not report the control variables.

\footnotetext{
${ }^{16}$ We thank Florian Peters for sharing that data with us.
} 
Table 3.9: Board size and monitoring

\begin{tabular}{|c|c|c|c|c|c|}
\hline Panel A: All & $\begin{array}{c}(1) \\
\text { Forced } \\
\text { Turnover }\end{array}$ & $\begin{array}{c}(2) \\
\text { Abnormal } \\
\text { Accruals }\end{array}$ & $\begin{array}{c}(3) \\
\text { Pays } \\
\text { Dividend }\end{array}$ & $\begin{array}{c}(4) \\
\text { Dividend/ } \\
\text { Equity }\end{array}$ & $\begin{array}{c}(5) \\
\text { Market } \\
\text { Leverage }\end{array}$ \\
\hline Ln(Board Size) & $\begin{array}{c}0.0106 \\
(0.9248)\end{array}$ & $\begin{array}{l}-0.2837 \\
(0.4484)\end{array}$ & $\begin{array}{c}0.7025^{* * *} \\
(0.0000)\end{array}$ & $\begin{array}{l}224.5353^{* * *} \\
(0.0000)\end{array}$ & $\begin{array}{c}-2.8100^{* *} \\
(0.0159)\end{array}$ \\
\hline $\operatorname{Ln}($ Board Size $) \times$ ROA & $\begin{array}{c}0.0007 \\
(0.4554)\end{array}$ & & & & \\
\hline Ln $($ Board Size $) \times$ PME Below & & $\begin{array}{c}-1.2234^{*} \\
(0.0699)\end{array}$ & & & \\
\hline ROA & $\begin{array}{c}-0.0283^{* * *} \\
(0.0000)\end{array}$ & $\begin{array}{c}0.3551^{* * *} \\
(0.0000)\end{array}$ & $\begin{array}{c}0.0287^{* * *} \\
(0.0000)\end{array}$ & $\begin{array}{c}14.0446^{* * *} \\
(0.0000)\end{array}$ & $\begin{array}{c}-0.7941^{* * *} \\
(0.0000)\end{array}$ \\
\hline PME Below & & $\begin{array}{c}9.0793^{* * *} \\
(0.0000)\end{array}$ & & & \\
\hline Controls & Yes & Yes & Yes & Yes & Yes \\
\hline Year Fixed Effects & Yes & Yes & Yes & Yes & Yes \\
\hline Industry Fixed Effects & Yes & Yes & Yes & Yes & Yes \\
\hline Sample Size & 19,348 & 19,177 & 19,375 & 19,150 & 19,476 \\
\hline Adj. (Pseudo) R-Squared & 0.1318 & 0.2839 & 0.3186 & 0.2747 & 0.5141 \\
\hline Panel B: Complex & $\begin{array}{c}(1) \\
\text { Forced } \\
\text { Turnover }\end{array}$ & $\begin{array}{c}(2) \\
\text { Abnormal } \\
\text { Accruals }\end{array}$ & $\begin{array}{c}(3) \\
\text { Pays } \\
\text { Dividend }\end{array}$ & $\begin{array}{c}(4) \\
\text { Dividend/ } \\
\text { Equity }\end{array}$ & $\begin{array}{c}(5) \\
\text { Market } \\
\text { Leverage }\end{array}$ \\
\hline Ln(Board Size) & $\begin{array}{l}-0.0103 \\
(0.9359)\end{array}$ & $\begin{array}{c}-2.0719 * * * \\
(0.0000)\end{array}$ & $\begin{array}{c}0.7343^{* * *} \\
(0.0000)\end{array}$ & $\begin{array}{r}46.0075 \\
(0.2879)\end{array}$ & $\begin{array}{l}1.8781^{*} \\
(0.0954)\end{array}$ \\
\hline Ln $($ Board Size $) \times$ Complex & $\begin{array}{c}0.0886 \\
(0.6396)\end{array}$ & $\begin{array}{c}2.5933^{* * *} \\
(0.0001)\end{array}$ & $\begin{array}{c}0.4174^{* *} \\
(0.0472)\end{array}$ & $\begin{array}{l}269.2768^{* * *} \\
(0.0005)\end{array}$ & $\begin{array}{l}-9.1834^{* * *} \\
(0.0000)\end{array}$ \\
\hline $\operatorname{Ln}($ Board Size $) \times$ ROA & $\begin{array}{l}0.0024^{*} \\
(0.0647)\end{array}$ & & & & \\
\hline Ln $($ Board Size $) \times$ Complex $\times$ ROA & $\begin{array}{c}-0.0133^{* *} \\
(0.0220)\end{array}$ & & & & \\
\hline Complex $\times$ ROA & $\begin{array}{r}0.0257^{* *} \\
(0.0496)\end{array}$ & & & & \\
\hline Ln $($ Board Size $) \times$ PME Below & & $\begin{array}{c}0.9697 \\
(0.2951)\end{array}$ & & & \\
\hline Ln $($ Board Size $) \times$ Complex $\times$ PME Below & & $\begin{array}{c}-3.7516^{* *} \\
(0.0190)\end{array}$ & & & \\
\hline Complex $\times$ PME Below & & $\begin{array}{c}7.7947^{* *} \\
(0.0288)\end{array}$ & & & \\
\hline ROA & $\begin{array}{c}-0.0311^{* * *} \\
(0.0000)\end{array}$ & $\begin{array}{c}0.3450^{* * *} \\
(0.0000)\end{array}$ & $\begin{array}{c}0.0326^{* * *} \\
(0.0000)\end{array}$ & $\begin{array}{l}11.4350^{* * *} \\
(0.0000)\end{array}$ & $\begin{array}{c}-0.7179^{* * *} \\
(0.0000)\end{array}$ \\
\hline PME Below & & $\begin{array}{r}4.6950^{* *} \\
(0.0152)\end{array}$ & & & \\
\hline Complex & $\begin{array}{l}-0.2491 \\
(0.5556)\end{array}$ & $\begin{array}{c}-5.3741^{* * *} \\
(0.0003)\end{array}$ & $\begin{array}{l}-0.7048 \\
(0.1279)\end{array}$ & $\begin{array}{c}-451.7719^{* * *} \\
(0.0085)\end{array}$ & $\begin{array}{c}32.9412^{* * *} \\
(0.0000)\end{array}$ \\
\hline Controls & Yes & Yes & Yes & Yes & Yes \\
\hline Year Fixed Effects & Yes & Yes & Yes & Yes & Yes \\
\hline Industry Fixed Effects & Yes & Yes & Yes & Yes & Yes \\
\hline Sample Size & 19,348 & 19,177 & 19,375 & 19,150 & 19,476 \\
\hline Adj. (Pseudo) R-Squared & 0.1335 & 0.2835 & 0.3136 & 0.2601 & 0.5567 \\
\hline Panel C: High Growth & $\begin{array}{c}(1) \\
\text { Forced } \\
\text { Turnover }\end{array}$ & $\begin{array}{c}(2) \\
\text { Abnormal } \\
\text { Accruals }\end{array}$ & $\begin{array}{c}(3) \\
\text { Pays } \\
\text { Dividend }\end{array}$ & $\begin{array}{c}(4) \\
\text { Dividend/ } \\
\text { Equity }\end{array}$ & $\begin{array}{c}(5) \\
\text { Market } \\
\text { Leverage }\end{array}$ \\
\hline Ln(Board Size) & $\begin{array}{l}-0.0554 \\
(0.6607)\end{array}$ & $\begin{array}{l}0.7158^{*} \\
(0.0720)\end{array}$ & $\begin{array}{c}0.7108^{* * * *} \\
(0.0000)\end{array}$ & $\begin{array}{c}229.2935^{* * *} \\
(0.0000)\end{array}$ & $\begin{array}{l}-2.1760 \\
(0.1153)\end{array}$ \\
\hline Ln $($ Board Size $) \times$ High Growth & $\begin{array}{c}0.1791 \\
(0.3358)\end{array}$ & $\begin{array}{c}-3.9470^{* * * *} \\
(0.0000)\end{array}$ & $\begin{array}{c}0.1088 \\
(0.6793)\end{array}$ & $\begin{array}{r}13.1409 \\
(0.8691)\end{array}$ & $\begin{array}{l}-2.1271 \\
(0.2209)\end{array}$ \\
\hline $\operatorname{Ln}($ Board Size $) \times$ ROA & $\begin{array}{l}-0.0003 \\
(0.7686)\end{array}$ & & & & \\
\hline Ln $($ Board Size $) \times$ High Growth $\times$ ROA & $\begin{array}{l}-0.0056 \\
(0.3000)\end{array}$ & & & & \\
\hline High Growth $\times$ ROA & $\begin{array}{c}0.0177 \\
(0.1006)\end{array}$ & & & & \\
\hline
\end{tabular}


Table 3.9 Continued

\begin{tabular}{|c|c|c|c|c|c|}
\hline Ln(Board Size $) \times$ PME Below & & $\begin{array}{c}-2.4278 * * * \\
(0.0016)\end{array}$ & & & \\
\hline Ln $($ Board Size $) \times$ High Growth $\times$ PME Below & & $\begin{array}{c}3.3706^{* *} \\
(0.0223)\end{array}$ & & & \\
\hline High Growth $\times$ PME Below & & $\begin{array}{c}-8.0190^{* *} \\
(0.0113)\end{array}$ & & & \\
\hline $\mathrm{ROA}$ & $\begin{array}{c}-0.0299 * * * \\
(0.0000)\end{array}$ & $\begin{array}{c}0.3594^{* * *} \\
(0.0000)\end{array}$ & $\begin{array}{c}0.0293^{* * *} * \\
(0.0000)\end{array}$ & $\begin{array}{c}13.6908 * * * \\
(0.0000)\end{array}$ & $\begin{array}{c}-0.7545^{* * *} \\
(0.0000)\end{array}$ \\
\hline PME Below & & $\begin{array}{c}11.9585^{* * *} \\
(0.0000)\end{array}$ & & & \\
\hline High Growth & $\begin{array}{l}-0.3611 \\
(0.3783)\end{array}$ & $\begin{array}{c}7.7653^{* * *} \\
(0.0000)\end{array}$ & $\begin{array}{l}-0.6625 \\
(0.2526)\end{array}$ & $\begin{array}{l}23.4390 \\
(0.8908)\end{array}$ & $\begin{array}{l}-1.8279 \\
(0.6292)\end{array}$ \\
\hline Controls & Yes & Yes & Yes & Yes & Yes \\
\hline Year Fixed Effects & Yes & Yes & Yes & Yes & Yes \\
\hline Industry Fixed Effects & Yes & Yes & Yes & Yes & Yes \\
\hline Sample Size & 19,348 & 19,177 & 19,375 & 19,150 & 19,476 \\
\hline Adj. (Pseudo) R-Squared & 0.1343 & 0.2866 & 0.3160 & 0.2713 & 0.5100 \\
\hline
\end{tabular}

This table presents the results of regressions on the relation between board size and a variety of firm outcomes that are related to monitoring activities. While Panel A illustrates the results across all firms, Panel B and $\mathrm{C}$ show the results for the two firm types complex and high-growth firms, respectively. The dependent variables comprise the dummy variable Forced Turnover that is equal to one if a firm experiences a forced turnover, Abnormal Accruals, the dummy variable Pays Dividend, the ratio Dividend/Equity, and Market Leverage. PME Below is a dummy variable that is equal to one if pre-managed earnings are below last year's earnings. The remaining variables, including the (omitted) controls, are the same as in previous analyses. Variable definitions can be found in Table B.1 in Appendix B. All models include industry and year fixed effects, as well as a constant term. Models (1) and (3) are probit models. The $p$-values are based on standard errors clustered at the firm-level and are reported in parentheses. ${ }^{*}, * *$, and $* * *$ indicate significance levels of $10 \%, 5 \%$, and $1 \%$, respectively.

Across all firms, we find no evidence of an association between board size and forced CEO turnover. For earnings management, however, we do find an indication for a monitoring effect. Board size on its own does not appear to have an effect. However, in situations when there is a special incentive for earnings management, that is, when the pre-managed earnings are below last year's earnings, abnormal accruals go down when boards become larger. This is indicative of the monitoring capacity explanation and could be due to more directors with specialized skills to prevent earnings management. The other proxies point in the same direction. Firms with larger boards have a significantly higher likelihood of paying dividends and they pay higher dividends than firms with smaller boards. In other words, they reduce the free cash flow problem, which also makes it more likely that they will have to raise external capital to finance investments. Lastly, firms with larger boards tend to have lower leverage. Since leverage is an external control mechanism, this could suggest, that when boards increase in size, these firms are no longer in need of that external control. All in all, these results are supportive of our monitoring capacity explanation, which supposes that firm risk goes down because of better monitoring and not inefficiencies.

For complex firms, which are presented in Panel B, we find a negative coefficient estimate on the triple interaction term, which indicates that the likelihood of forced CEO turnovers increases with board size when firm performance is poor. This result clearly points toward a monitoring 
effect of board size in complex firms. In addition, the results for earnings management show that abnormal accruals go down with board size. The significant positive coefficient on the interaction term between board size and our complexity dummy seems to suggest that in such firms, earnings management increases. However, an F test for joint significance reveals that the two coefficients together are not significantly different from zero, suggesting that board size itself has neither a positive nor negative effect on earnings management in complex firms. When we examine the triple interaction term, on the other hand, we see that it is significantly negative, which says that when these firms have an incentive to manipulate their earnings, large boards appear to reduce that effect significantly. Additionally, the likelihood of paying a dividend increases more strongly in complex firms than in non-complex firms when board size increases, and complex firms also pay higher dividends, whereas we find no effect in non-complex firms. Finally, while leverage goes up with board size in non-complex firms, it actually goes down in complex ones. Taken together, this again supports our expectation that increases in board size in complex firms increase the monitoring capacity of the board, which is in line with reduced firm risk due to better monitoring.

Results for high growth firms, presented in Panel C, look somewhat different. With respect to forced turnover, we find no significant effect. For earnings management, the results are somewhat unintuitive. Larger boards appear to reduce general earnings management in high-growth firms compared to low-growth firms. However, when pre-managed earnings are down compared to last year, that is, when there is a stronger incentive to manage earnings, abnormal accruals actually increase with board size in high-growth firms compared to low-growth firms. This does not support a monitoring effect. With respect to the likelihood of paying a dividend at all and the question of higher payouts, we find no additional board size effect in high-growth firms beyond what is already observed in low-growth firms. No effect can be detected for leverage, neither for high-growth nor for low-growth firms. Taken together, we find no direct evidence supporting a monitoring effect in high-growth firms, and we find some evidence that opportunistic earnings management does increase. While these results do point toward a negative effect of larger boards in high-growth firms, they are not clearly suggesting inefficiencies. That is why we further investigate this as a possible explanation in an area that is of particular importance to high growth firms, namely innovation, in the next section 


\subsubsection{Board size and innovation inefficiency}

Innovation has a special importance for high-growth firms (Audretsch et al., 2014) and board structure can have a tremendous effect on the success of innovation (Balsmeier et al., 2017; Kang et al., 2018; Nguyen et al., 2021). That is why we analyze the association of board size and patents to find further evidence for our two explanations. We use the extended patent dataset from Kogan et al. (2017), who not only have the number of patents and their citations, but also calculate a dollar value for each patent. ${ }^{17}$ That allows us to specifically test for inefficiencies, as we relate board size not just to the overall number of patents, their citations, and overall value, but also to the overall value per $R \& D$ expenditures and the value of each individual patent. Results for those analyses are presented in Table 3.10 .

For all firms we only find weak evidence in Column (5) that the value per patent goes down when board size increases, whereas all the other relations are not significant. In Panel B, we can see that board size does not have a specific effect in complex firms beyond what can be observed in non-complex firms. Interestingly, we can see that firms with larger boards have more patents (Column (1)) with more citations (Column (2)) that have a higher total value (Column (3)). Moreover, since the patent value in relation to R\&D expenditures (Column (4)) and the value of each patent (Column (5)) go up, we surmise that the innovation process also becomes more efficient as boards grow in size. The fact that the interaction terms with the complexity dummy are not significant can be interpreted as complex firms not being significantly different from non-complex firms in this respect. Nevertheless, since all values are positive, the findings again support our monitoring capacity explanation.

For high-growth firms, the interpretation does not hold. The results in Columns (1) through (3) seem to suggest that these firms benefit as well from larger boards, since they produce a significantly higher number of patents that have more citations and a higher combined value. However, the results in Columns (4) and (5) reveal that the opposite is true. Both the patent value in relation to $R \& D$ expenditures as well as the average value per patent go down when boards increase in size, indicating that those firms pay significantly more to produce patents with lower quality. Both results provide a clear sign of inefficiencies in high-growth firms with large boards.

This effect is not only statistically significant, but also economically meaningful. For example,

\footnotetext{
${ }^{17}$ We thank Kogan et al. (2017) for providing their data online.
} 
Table 3.10: Board size and innovation across all firms

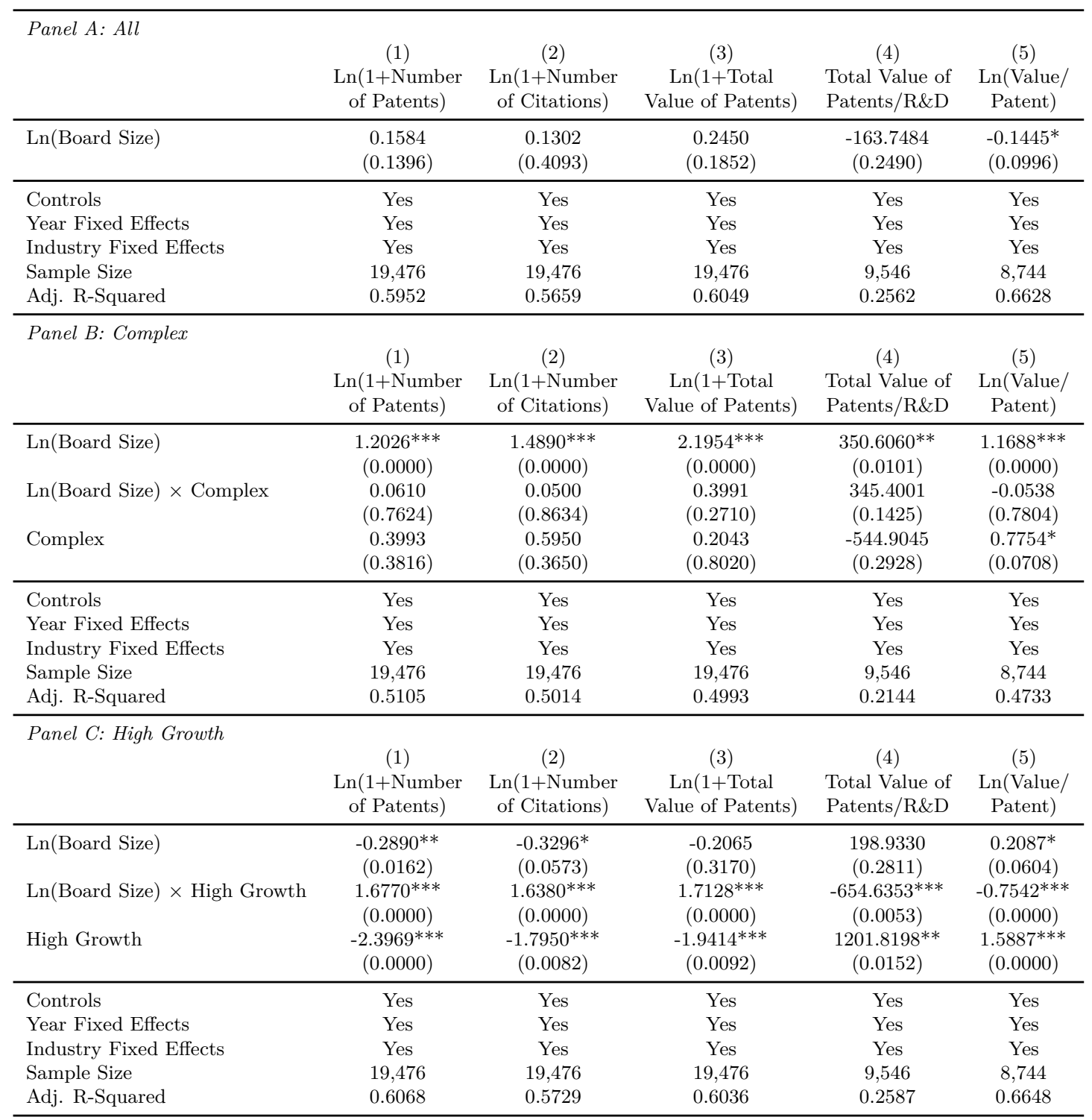

This table presents the results of regressions on the relation between board size and a variety of innovation outcomes. While Panel A illustrates the results across all firms, Panel B and C show the results for the two firm types complex and high-growth firms, respectively. The dependent variables are based on the data from Kogan et al. (2017) and comprise Ln(1+Number of Patents), Ln(1+Number of Citations), Ln(1+Total Value of Patents), the ratio Total Value of Patents/RED), and $L n$ (Value/Patent). The remaining variables, including the (omitted) controls, are the same as in previous analyses. Variable definitions can be found in Table B.1 in Appendix B. All models include industry and year fixed effects, as well as a constant term. The $p$-values are based on standard errors clustered at the firm-level and are reported in parentheses. *, **, and *** indicate significance levels of $10 \%$, $5 \%$, and $1 \%$, respectively. 
based on the coefficient estimate of -0.7542 in Model (5), an increase in board size by one standard deviation (2.30) at the median (9) would be associated with a comparably lower value per patent in high-growth firms of $19.27 \%$. Considering that the median (mean) value per patent in our sample is $\$ 15.96$ ( $\$ 41.60$ ) million, this implies that each patent produced by high-growth firms would be worth $\$ 3.08$ ( $\$ 8.02$ ) million less than the ones produced by other firms.

These results, taken together with the ones from the previous section, provide strong evidence that an improved monitoring capacity of large boards can explain the reduction of firm risk in complex firms, as well as that inefficiencies in large groups can explain the reduction of firm risk in high-growth firms. As initially suspected, the reason for the reduction in firm risk appears to depend on the particular firm type. In complex firms, the lower risk seems to be mostly driven by an increased monitoring capacity of large boards, which would indicate that volatility is lower because of boards preventing unnecessary risk-taking. For high-growth firms, on the other hand, we find little evidence of a monitoring effect for larger boards, which could be explained by the higher monitoring costs these firms face. As expected, our evidence suggests that these firms quickly begin to face inefficiencies when their boards grow. When we analyze the effects across the whole universe of firms without distinguishing a certain type, the monitoring capacity appears to have the greatest explanatory power.

\subsection{Conclusion}

This paper investigates the association between board size and firm risk for a sample of U.S. firms from 1996 to 2015, with a special focus on different firm types. We find that stock return volatility goes down across all firms when boards become larger and this effect is amplified in high-growth firms but not in complex ones. This result is robust to alternative measures of board size, a variety of additional control variables, and tests for endogeneity.

We consider and test two competing explanations for this finding. While previous studies ascribe the reduction in volatility to communication and coordination problems of large boards that lead to inefficiencies and thus lower variability, we consider that larger boards can have a greater capacity for monitoring. Our results show that, across all firms and complex ones, larger boards are associated with a higher propensity to pay dividends, paying higher dividends, reduced earnings management, especially in situations where there is an incentive to increase abnormal accruals, and lower leverage. In addition, they are associated with a higher likelihood of forced CEO turnovers after poor performance in complex firms. For high-growth firms, however, we find that earnings management increases when there is an incentive to manage earnings upward, 
while we find no evidence of better monitoring when it comes to dividends or leverage compared to low-growth firms. With respect to innovation, though, which is of crucial importance to high-growth firms, we find strong evidence that larger boards are associated with a reduction in the value of individual patents and the value of patents in relation to $R \& D$-expenditures.

These results are supportive of our conjecture that larger boards overall lead to better monitoring, which means that the reduction in firm risk is actually positive as it most likely comes from avoiding unnecessary risks. This is particularly true for complex firms, where theory predicts that they would benefit from larger boards. At the same time, the results for high-growth firms support the inefficiency explanation, especially with respect to the innovation processes.

Our findings provide strong evidence that, unlike suggested by previous studies, larger boards can have beneficial effects when it comes to firm risk, as they can enable better monitoring. However, this effect on risk is not uniform across all firms and different firm types can benefit from different board structures when they want to affect their stock price risk. This is important to consider when evaluating a firm's board. Conceivably, other aspects of board structure (e.g., diversity or independence) may likewise vary in their effect in different firm types. We leave this research to future studies. 


\section{B Appendix}

Table B.1: Variable definitions

\begin{tabular}{|c|c|c|}
\hline Variable & Definition & Data Source \\
\hline \multicolumn{3}{|c|}{ Volatility Measures } \\
\hline Volatility (\%) & $\begin{array}{l}\text { Annualized standard deviation of daily stock returns for the firm's } \\
\text { fiscal year. }\end{array}$ & $C R S P$ \\
\hline Idiosyncratic & Annualized standard deviation of daily residuals, obtained from & $C R S P$ \\
\hline Volatility (\%) & $\begin{array}{l}\text { Fama-French three-factor model estimations, for the firm's fiscal } \\
\text { year. The factor model is estimated on a yearly basis using data } \\
\text { from Kenneth R. French's data library. }\end{array}$ & $\begin{array}{l}\text { French's } \\
\text { data library }\end{array}$ \\
\hline
\end{tabular}

Firm Type Indicators

Complex

High Growth
Dummy variable equal to one if the firm's complexity score, derived from PCA and based on the number of business segments, the natural logarithm of sales, and book leverage, is above the sample median; zero otherwise.

Dummy variable equal to one if the firms ratio of $R \& D$ expenditures to the book value of assets is above the 75 th percentile; zero otherwise.
Compustat

Compustat

ISS Directors

Number of directors on the board.

ISS Directors

directors; zero otherwise.

Medium Board

Dummy variable equal to one, if the board consists of 9 to 11

ISS Directors directors; zero otherwise.

Large Board

Dummy variable equal to one, if the board consists of 12 to 22

ISS Directors directors; zero otherwise.

Independence $(\%)$

Number of independent directors divided by the total number of

ISS Directors directors on the board.

CEO Duality Dummy variable equal to one, if the CEO is also the chairperson

ISS Directors of the board; zero otherwise.

CEO Ownership (\%) Percentage of a company's shares owned by the CEO, options excluded.

CEO Tenure $\quad$ Years since the CEO took over office.

ExecuComp

\section{External Governance}

E Index

Entrenchment index introduced by Bebchuk et al. (2009).

ISS

Governance

\section{Further}

Total Assets

Book value of assets.

Compustat

Book Leverage (\%)

Sum of long-term debt and current liabilities divided by the book value of total assets.

ROA $(\%)$

Cash/Assets (\%)

Return on assets. Net income divided by the book value of assets.

Cash and short-term investments divided by the book value of assets.

R\&D/Assets (\%)

R\&D expenditures divided by the book value of assets.

CAPEX/Sales (\%)

Capital expenditures divided by sales.

Firm Age
Compustat

Compustat

Compustat

Compustat

Compustat

CRSP the earliest year possible. 
Table B.1 Continued

\begin{tabular}{|c|c|c|}
\hline Forced Turnover & $\begin{array}{l}\text { Dummy variable equal to one if the firm experiences a forced } \\
\text { turnover in the current fiscal year; zero otherwise. Forced } \\
\text { turnovers are determined using the updated dataset from Pe- } \\
\text { ters and Wagner (2014) and Jenter and Kanaan (2015). }\end{array}$ & $\begin{array}{l}\text { Florian } \\
\text { Peters }\end{array}$ \\
\hline Abnormal Accruals & $\begin{array}{l}\text { Abnormal accruals based on the modified Jones (1991)-model } \\
\text { from Dechow et al. (1995). }\end{array}$ & Compustat \\
\hline Pays Dividend & $\begin{array}{l}\text { Dummy variable equal to one if the firm pays dividends in the } \\
\text { current fiscal year; zero otherwise. }\end{array}$ & Compustat \\
\hline Dividend/Equity & Dividends paid divided by the book value of equity. & Compustat \\
\hline $\begin{array}{l}\text { Market Leverage } \\
(\%)\end{array}$ & $\begin{array}{l}\text { Sum of long-term debt and current liabilities divided by the sum } \\
\text { of market equity and book debt. }\end{array}$ & Compustat \\
\hline Number of Patents & $\begin{array}{l}\text { Number of patents filed (and eventually granted) during the firm's } \\
\text { fiscal year, based on the updated Kogan et al. (2017) dataset. }\end{array}$ & $\begin{array}{l}\text { Stoffman's } \\
\text { website }\end{array}$ \\
\hline Number of Citations & $\begin{array}{l}\text { Number of forward citations received by the patents filed (and } \\
\text { eventually granted) during the firm's fiscal year, based on the } \\
\text { updated Kogan et al. ( } 2017 \text { ) dataset. }\end{array}$ & $\begin{array}{l}\text { Stoffman's } \\
\text { website }\end{array}$ \\
\hline $\begin{array}{l}\text { Total Value of } \\
\text { Patents }\end{array}$ & $\begin{array}{l}\text { Total dollar value (in millions) of all patents filed (and eventually } \\
\text { granted) during the firm's fiscal year, based on the updated Kogan } \\
\text { et al. (2017) dataset. }\end{array}$ & $\begin{array}{l}\text { Stoffman's } \\
\text { website }\end{array}$ \\
\hline $\begin{array}{l}\text { Total Value of } \\
\text { Patents/R\&D }\end{array}$ & $\begin{array}{l}\text { Total dollar value (in millions) of all patents filed (and eventually } \\
\text { granted) during the firm's fiscal year divided by R\&D expenditures, } \\
\text { based on the updated Kogan et al. (2017) dataset. }\end{array}$ & $\begin{array}{l}\text { Stoffman's } \\
\text { website; } \\
\text { Compustat }\end{array}$ \\
\hline Value/Patent & $\begin{array}{l}\text { Mean value of the patents filed (and eventually granted) during } \\
\text { the firm's fiscal year, based on the updated Kogan et al. (2017) } \\
\text { dataset. }\end{array}$ & $\begin{array}{l}\text { Stoffman's } \\
\text { website }\end{array}$ \\
\hline
\end{tabular}

This table provides an overview of the different variables, their definitions, and their source. 


\title{
4 Board Structure and Ambiguity
}

\author{
Joint work with Alexander Merz. \\ Under review at the Journal of Financial and Quantitative Analysis.
}

\begin{abstract}
Recent literature has highlighted the relevance of ambiguity for corporate finance decisions. Using the NYSE and NASDAQ listing rule changes to establish causality, we show that board oversight can significantly reduce ambiguity for investors. In line with the literature that suggests complex and fluctuating firm policies are more difficult to evaluate and cause ambiguity, we also find that independent directors reduce fluctuations in several firm policies. Firm values, however, only increase in stable industries; in dynamic ones where more adjustments are necessary, they decline, suggesting that independent directors prevent necessary changes in certain environments.
\end{abstract}

Acknowledgments: We thank Christian Andres, Sebastian Firk, Quan Gan, Richard Herron, Olaf Korn, Laura-Chloé Kuntz, Nico Lehmann, Holger Mueller, Georg Rickmann, Onur K. Tosun, Yasutomo Tsukioka, Lennart Ulrich, Rick Wilson and seminar participants at the $40^{\text {th }}$ EAA Annual Congress, the $5^{\text {th }}$ Paris Financial Management Conference, the $30^{\text {th }}$ Australasian Finance \& Banking Conference, the $7^{\text {th }}$ Auckland Finance Meeting, the $67^{\text {th }}$ MFA Annual Meeting, the $57^{\text {th }}$ SWFA Annual Meeting, the $22^{\text {nd }}$ FMA European Conference. All remaining errors are our own. 


\subsection{Introduction}

Based on Knight's (1921) seminal work, a number of recent corporate finance papers have analyzed the effects of risk and ambiguity, or Knightian uncertainty, on corporate policy decisions. ${ }^{1}$ Both theoretical models (e.g., Garlappi et al., 2017) and empirical papers (e.g., Izhakian et al., 2021) show that the two affect outcomes in different ways. Ambiguity generally has a detrimental effect on shareholders as it leads them to overvalue negative and undervalue positive outcomes (Agliardi et al., 2016; Herron and Izhakian, 2018). Therefore, it is in the interest of the shareholders to reduce ambiguity, which can be achieved through predictable strategies, that is, strategies that do not deviate much from long-term means or that do not exhibit strong variations (Packard and Clark, 2020). To this end, shareholders could exert influence over management via the board, which is their primary means of control (John and Senbet, 1998). Thus far, however, no study has empirically investigated whether the board actually does influence policy predictability or ambiguity.

In this paper, we consider if board independence can reduce the ambiguity faced by shareholders. Specifically, we exploit the quasi-exogenous shock to board independence through the listing rule changes at the NYSE and NASDAQ exchanges that were introduced in 2003 in a differencein-differences (DID) analysis. As our measure of ambiguity, we use the volatility of volatility (VOV) of stock returns which is frequently used as a proxy in the finance literature. As argued in prior studies, time-varying or stochastic volatility fits the concept of ambiguity well as the underlying processes are so complex that they are difficult to learn and predict (Carr and Lee, 2009; Epstein and Ji, 2013). Moreover, a number of studies in the literature indicate that volatility is indeed time-varying in financial markets ${ }^{2}$ and it is well known that certain risk-related policy decisions can increase or decrease volatility. ${ }^{3}$ Each policy can thus be a source of ambiguity, and frequent changes in these policies, therefore, will increase the VOV, making it a suitable aggregate ambiguity proxy in a corporate finance context as well.

Our sample is based on the Institutional Shareholder Services (ISS) Database (formerly RiskMetrics), from which we collect governance and in particular board data for fiscal years 1996 to 2015. We obtain daily stock returns from the Center for Research in Security Prices (CRSP) to calculate monthly stock return volatilities, from which we then compute an annual "raw" VOV

\footnotetext{
${ }^{1}$ Risk refers to scenarios in which the outcome is unknown, yet the probabilities of the potential outcomes are known. Ambiguity means that these probabilities are either also unknown or not uniquely assigned.

${ }^{2}$ See, for example, Bansal et al. (2014), Agarwal et al. (2017), Baltussen et al. (2018), and Huang et al. (2019).

${ }^{3}$ Chan et al. (2001) and Kothari et al. (2002), for example, show this for research and development expenditures.
} 
as the standard deviation of those volatilities. In addition, we also calculate a "scaled" VOV by dividing the raw VOV by the average annual volatility, as firms with higher volatility tend to have greater VOV (Baltussen et al., 2018).

For our identification strategy, we separate the firms into two groups. The first is made up of those firms that were not in compliance with the independence requirement in 2001 (i.e., they did not already have a majority independent board), the year before the listing rules were introduced. For these "noncompliant firms" the listing rule changes were indeed an exogenous shock (Humphery-Jenner et al., 2019). The second group comprises control firms that were already compliant in 2001 and were not affected by the changes. To mitigate concerns that the assignment of firms to the two groups was nonrandom and to identify adequate control firms, we conduct a propensity score matching (PSM). We also carry out several robustness checks, including different specifications of the PSM, an alternative matching procedure, and a test for the parallel trend assumption.

Our initial univariate DID results show that the VOV of treated firms is reduced by margins that are highly statistically and economically significant. In the main analysis, comprised of multivariate regressions with additional control variables as well as firm and year fixed effects, this result is confirmed. Importantly, the results hold for both of our VOV measures, indicating that the effect is not a statistical artifact caused by high-volatility firms. In the next step, we focus on different time periods that might potentially drive our results. Since we have a rather long post-event period, it is possible that events other than the listing rule changes contribute to the VOV reduction. We therefore truncate our sample in 2007 so that we have equal preand post-event windows. Next, we exclude fiscal years 2002 through 2004, which represent a transition phase that firms could use to make the necessary adjustments to their board structure. Finally, we exclude fiscal years 2008 and 2009 because the financial crisis was a time of both extremely high volatility and VOV (Huang et al., 2019). In all three cases, our results remain consistent with the baseline estimation.

We also explore the effect of increased board independence in more detail by conditioning it on several cross-sectional differences in other governance and firm characteristics that existed in treatment firms at the time of the change. To that end, we split the treatment firms at the median of CEO duality, CEO tenure, board size, board co-option, the entrenchment index (E index), and research and development (R\&D) intensity. With the exception of CEO tenure, the VOV reduction is virtually identical between above- and below-median firms, suggesting 
that these other governance or firm characteristics do not moderate the independence effect. In addition, we split the effect for firms that are more strongly afflicted by information asymmetry and stock market liquidity, both of which are connected to ambiguity (Williams, 2014; Easley and O'Hara, 2009). The results show that the reduction in ambiguity is indeed greater for firms suffering from higher information asymmetry and low stock liquidity.

Next, we explore possible channels through which independent directors can influence ambiguity. As ambiguity can be caused by frequent changes in firm policies, we expect that independent directors will lead firms to adopt more stable policies, defined as those that exhibit smaller variances and deviations from the mean (Bowman, 1963). We establish two measures for policy stability: first, we use the absolute change in the policy measure from year to year, which identifies the stability across years; and second, we use the annualized standard deviation of the policy measure, calculated from quarterly data, which identifies the fluctuations within a fiscal year. Both variants show that increased independence leads to greater stability in total investments, net investments, particularly acquisition expenses, cash holdings, and leverage. Furthermore, we find evidence that property, plant, and equipment (PPE) values become more stable over the years. Again, these findings are not only statistically significant but also highly economically meaningful. All of this supports our supposition that better monitoring leads to decisions in the firm's risk-related policies that are easier to evaluate and thus lower ambiguity.

As prior literature has shown that a one-size-fits-all approach to corporate boards is not always beneficial (Wintoki, 2007), we explore the possibility that a reduced VOV may be a negative outcome in cases where firms must constantly adapt and make frequent changes to their policies. Independent directors could limit the ability of firms to carry out the necessary changes if they implement stable strategies in highly dynamic or volatile industries. Drawing on organizational and management literature, we separate the effect for firms in highly dynamic and stable as well as in highly volatile and low-volatility industries. We repeat our baseline analysis for both groups and find that the VOV is reduced equally. When we investigate market valuations (i.e., Tobin's Q and Total Q), we find highly significant increases for firms in stable and low-volatility industries, but significant decreases in dynamic and volatile industries. While the majority of firms benefit from the changes in board structure, this result further supports the notion that a blanket approach to corporate governance reforms is not without negative side effects.

Finally, we subject our analyses to a battery of robustness checks, including alternative matching specifications and procedures as well as tests of the parallel trends assumption. To allay concerns 
about an omitted variable bias, we include a variety of other control variables in our models, such as board size and compensation delta and vega, and market-wide volatility. We then exclude firms that have different CEOs in 2001 and 2003 to avoid confounding the monitoring effect with a "new CEO effect" and we exclude closely-controlled firms, which are exempt from the independence requirement. Lastly, we recalculate our VOV measures based on idiosyncratic volatility, which is more likely to be influenced by managerial actions. In all cases, our results remain virtually unchanged.

Our paper contributes to the literature in several ways. First, we contribute to the fast-growing field of research that is focused on ambiguity in a corporate finance context. Theoretical models demonstrate that ambiguity leads to suboptimal decisions (Garlappi et al., 2017; Agliardi et al., 2016; Berger and Eeckhoudt, 2021). Empirical work analyzes the effect of ambiguity on stock option exercise (Izhakian and Yermack, 2017), payout policies (Herron and Izhakian, 2018), innovation (Coiculescu et al., 2019), capital structure (Izhakian et al., 2021), and mergers and acquisition activities (Herron and Izhakian, 2020). Ours is the first empirical study in this field to show that board structure can significantly reduce ambiguity for investors.

Second, we contribute to the strand of literature that analyzes the effect of independent directors on corporate actions and outcomes, such as operating performance or CEO incentive pay (e.g., Byrd and Hickman, 1992; Nguyen and Nielsen, 2010; Knyazeva et al., 2013; Wei et al., 2016; Souther, 2021). Our results show that board independence leads to less volatile risk-related firm policies. In other words, independent directors effect more stable investment policies, particularly in acquisitions, or leverage decisions that are easier for shareholders and analysts to evaluate, which lowers the volatility of volatility.

Third, we contribute to the literature that analyzes the economic effects of corporate governance reforms (e.g., Linck et al., 2009; Price et al., 2011; Hu et al., 2020; Chen et al., 2021). In our case, we show that the changes to the listing rules that were meant to improve internal monitoring mechanisms have a decreasing effect on the VOV, that is, they lower the ambiguity for investors. However, this appears to be beneficial only for firms not operating in environments that are subject to strong and frequent changes.

The rest of the paper is organized as follows. Section 4.2 reviews the literature and details our research question. Section 4.3 describes the empirical approach and the data set. The results are presented in Section 4.4 and Section 4.5 concludes the paper. 


\subsection{Literature review and research question}

In his seminal work, Knight (1921) introduced the dichotomy between risk and ambiguity. The principal difference between these two concepts is that risk can be quantified according to a probability model, while no unique model exists for determining ambiguity. As a consequence, economic actors do not have a clear understanding of the possible outcomes of their decisions (Agliardi et al., 2016). Ellsberg (1961), in his famous experiment, demonstrated that people exhibit ambiguity aversion. Since then, the impact of ambiguity has become a major focus in many areas of economic research; several papers have confirmed not only the existence of ambiguity aversion but also that people are even willing to incur costs to avoid ambiguity (e.g., Charness and Gneezy, 2010; Trautmann and Van De Kuilen, 2015).

In a finance context, ambiguity has largely been the focus of capital market and asset pricing research. ${ }^{4}$ More recently, a large number of studies have incorporated the concept into corporate finance settings. In a theoretical model, Garlappi et al. (2017), for example, reveal the negative outcomes of ambiguity within the board of directors on corporate investment decisions. Agliardi et al. (2016) investigate the effect of ambiguity in a contingent claims context and find that well-diversified shareholders make suboptimal decisions, such as exercising the bankruptcy option prematurely and overvaluing debt. Empirical work also shows that risk and ambiguity separately affect corporate finance decisions, often in opposite directions (e.g., Izhakian and Yermack, 2017; Coiculescu et al., 2019; Herron and Izhakian, 2020; Izhakian et al., 2021). A crucial insight from both strands of literature is that ambiguity leads investors to overvalue negative outcomes and undervalue positive outcomes (e.g., Epstein and Schneider, 2008; Agliardi et al., 2016; Herron and Izhakian, 2018). That is, shareholders cannot correctly assess the actions of managers based on what they observe in the market. Moreover, ambiguity implies market incompleteness, which limits the extent to which (agency) problems can be solved contractually (Mukerji and Tallon, 2001).

We build on these insights by analyzing if shareholders strive to reduce ambiguity through their influence on the board of directors. The theoretical literature suggests that predictable policy decisions will reduce the amount of ambiguity and make it easier for shareholders to evaluate the actions taken by management (Packard and Clark, 2020). Decisions that are unique, unfamiliar, and exhibit strong fluctuations, on the other hand, can increase ambiguity, as they are more

\footnotetext{
${ }^{4}$ See, for example, Chen and Epstein (2002), Pflug and Wozabal (2007), Epstein and Schneider (2008), Easley and O'Hara (2009), Boyarchenko (2012), Ju and Miao (2012), Epstein and Ji (2013), Brenner and Izhakian (2018), and Augustin and Izhakian (2020).
} 
difficult for shareholders, and even professional analysts, to understand and evaluate (Litov et al., 2012; Benner and Zenger, 2016). ${ }^{5}$ The empirical literature also shows that shareholders dislike fluctuations in corporate policy decisions (e.g., Kor and Mahoney, 2005; Xiang et al., 2020) and that stable strategies, defined as policy decisions that do not deviate significantly from a long-term mean or exhibit greater variances, provide superior performance as measured by the return on investment (Bowman, 1963; Kunreuther, 1969; Remus, 1978).

To have an impact on these decisions, shareholders can use their influence on the board of directors, the primary means for controlling shareholders (John and Senbet, 1998). In classical agency models, independent directors or outsiders are representatives of the shareholders and are typically tasked with monitoring management and ensuring that the decisions are made in the interest of the principal (Jensen, 1993; Denis and McConnell, 2003; Hermalin and Weisbach, 2003). Despite some concerns in the literature that independent directors are not necessarily ideal monitors in some specific situations (e.g., Coles et al., 2008), extensive empirical research supports the notion that outsiders do carry out a monitoring function and add value to the firm (e.g., Byrd and Hickman, 1992; Nguyen and Nielsen, 2010). More specifically, independent directors have been shown to positively affect, among other things, CEO appointments and dismissals (e.g., Knyazeva et al., 2013), market reactions to the adoption of anti-takeover measures (e.g., Brickley et al., 1994), and takeover premiums (e.g., Cotter et al., 1997). No study so far has analyzed the effect of independent directors on either the stability of corporate policy decisions or ambiguity in general. We expect that majority independent boards will reduce the level of ambiguity.

In prior studies, the type of ambiguity that investors face has often been operationalized as uncertainty about risk, or the volatility of volatility, which fits the theoretical concept well. Time-varying or stochastic volatility implies that there exists not just a probability distribution for stock returns, but also a variation in the assessment of that distribution (e.g., Klibanoff et al., 2005; Baltussen et al., 2018). A large amount of evidence suggests that volatility is indeed time-varying in financial markets and thus relevant both in a theoretical and empirical sense. ${ }^{6}$ Further, these studies suggest that the dynamics of the volatility are so complex that it is unlikely that even a sophisticated economic agent would be able to learn about the underlying process

\footnotetext{
${ }^{5}$ Reasons why managers choose unfamiliar and complex strategies include, inter alia, a desire to make them harder for competitors to copy, but also overconfidence and attempts to make strategies appear to be of high quality (Rivkin, 2000; Wu and Knott, 2006).

${ }^{6}$ See, for example, Eraker and Shaliastovich (2008), Bollerslev et al. (2012), Drechsler (2013), Bansal et al. (2014), Agarwal et al. (2017), Baltussen et al. (2018), Campbell et al. (2018), and Huang et al. (2019).
} 
and develop any reasonable level of confidence about future volatility behavior (Carr and Lee, 2009; Epstein and Ji, 2013).

VOV is also useful for capturing ambiguity faced by shareholders in a corporate finance context, because it is a direct empirical consequence of managerial decisions in risk-related corporate finance and investment policies that, as we describe above, cause ambiguity in the first place. ${ }^{7} \mathrm{We}$ will illustrate this using the example of $R \& D$ expenditures. While increases in $R \& D$ investment are generally associated with increased firm value (Hall et al., 2005) and improved operating performance (Hou et al., 2021), they are also often long-term investments with highly uncertain outcomes (Baysinger et al., 1991; Kothari et al., 2002), which makes them risky. This inherent riskiness of $\mathrm{R} \& \mathrm{D}$ expenditures is reflected in the volatility of stock returns, meaning that increases (decreases) in R\&D investments increase (decrease) volatility (Chan et al., 2001; Hou et al., 2021). Frequent changes in expenditures then lead to higher VOV. As each individual policy is a potential source of ambiguity, the VOV represents an aggregate measure of the individual ambiguities. Thus, there is a direct link between corporate policy decisions and the VOV and thus the ambiguity perceived by the shareholder.

To empirically test whether independent directors on the board do indeed address this problem, we use the listing rule changes made by the NYSE and NASDAQ exchanges in the early 2000s that required firms to have majority independent boards. Studies that have also used this setting have concluded that the exogenous shock to board independence provides a sharp tool for making causal inferences and that it increased board oversight. Armstrong et al. (2014) find that firms with majority independent boards reduce the information asymmetry between informed and uninformed investors. Guo and Masulis (2015) report that previously noncompliant firms have increased CEO turnover following poor performance, which the authors attribute to enhanced monitoring. Increasing board independence has also led to more effective control of overconfident and powerful CEOs. Banerjee et al. (2015) show that in firms with overconfident CEOs, risk and investment exposure have fallen, while post-acquisition returns have grown. This is seen as an indication of how stronger board oversight has improved CEO decision-making. Humphery-Jenner et al. (2019) provide evidence that greater board independence can serve to rein in powerful CEOs and align their interests more closely with those of the shareholders. In firms that were noncompliant with the listing rules and had powerful CEOs, there was a marked increase in R\&D expenditures with subsequently higher numbers of patents that turned out to

\footnotetext{
${ }^{7}$ Agliardi et al. (2016) also include time-varying volatility in their model to capture the ambiguity for the shareholder.
} 
be more valuable. Finally, Balsmeier et al. (2017) analyze the effect of board independence on innovation and find that affected firms increase patent output and citations. With respect to the body of research on the effect of independent directors, they conclude that these studies paint a picture of independent directors indeed carrying out an oversight function as predicted by standard agency models, alleviating concerns that the role of monitors cannot be filled by outsiders.

It is important to note that none of these studies address the issue of ambiguity or VOV. Bargeron et al. (2010) show that independence reduces stock return volatility, yet VOV is distinctly different from volatility and the two are only weakly correlated (Huang et al., 2019). Armstrong et al. (2014) provide evidence that more independent directors lead to greater transparency, which could potentially influence ambiguity, yet they do not test for it. Even if we assumed that increased transparency reduces ambiguity, Armstrong et al. (2014) provide no evidence of the channel that could lead to this result. In our study, we investigate possible sources of ambiguity by analyzing effects of board independence on different firm policies. In a way, our results complement the evidence in Armstrong et al. (2014), as we show that board independence leads to less variation in investment decisions, which could result in reduced information asymmetry, increased analyst following, and lower forecast errors. We formulate our expectation accordingly:

Majority independent boards will exercise greater monitoring and reduce the level of ambiguity as measured by the VOV. They will accomplish this by effecting lower fluctuations in risk-related policies.

\subsection{Empirical approach and data set}

\subsubsection{Listing rules and difference-in-differences design}

After several accounting scandals in the U.S. in the early 2000s by, for example Enron, major changes in corporate governance regulation were instituted. In July 2002, Congress passed the Sarbanes-Oxley Act (SOX), which contained several provisions to considerably reorganize financial reporting by publicly traded firms and increase the legal accountability of firms' executives and directors. At about the same time, the major stock exchanges NYSE and NASDAQ each announced proposals to change their listing rules, which the Security and Exchange Commission (SEC) approved, with minor amendments, in November $2003 .{ }^{8}$ At the core of the new exchange

\footnotetext{
${ }^{8}$ For a detailed overview of the time line of the introduction of SOX and the NYSE and NASDAQ listing rule changes, as well as their main provisions, see Chhaochharia and Grinstein (2007).
} 
listing rules stood the increased role of independent directors. In particular, the main provision required that listed firms have a majority of independent directors on their board. ${ }^{9}$ All firms not already fulfilling that requirement had to increase the number of independent directors. The deadline for compliance with the rules for listed firms was October 31, 2004, while firms with classified boards had to comply by December 31, 2005.

We utilize this quasi-exogenous shock to board structure from the listing rule changes to examine the causal effect of board independence on the VOV, using a DID approach. This identification strategy is based on the fact that only a subgroup of firms was affected by the rules, namely the "noncompliant" firms that did not already have majority independent boards. "Compliant" firms, however, were not required to change their board structure and, thus, serve as potential control firms in analyzing the effect of the new regulation. This is a different situation than that of the mandatory changes brought about by SOX, which affected nearly all U.S. firms. ${ }^{10}$ Thus, even if SOX did have an effect on the VOV, it would have affected all firms and should not prevent us from identifying the effect of the listing rule changes on the VOV. Similarly, Armstrong et al. (2014) conclude that the changes to the listing rules provide a powerful setting for detecting causal effects. If our prediction that improved board oversight diminishes ambiguity is correct, we should see a reduction in the VOV in firms that had to change their board independence compared to firms that were unaffected by this particular mandate.

We test this in our baseline DID regression model, which has the following form:

$$
V O V_{i, t}=\alpha+\beta \text { Post }_{t} \times \text { Treated }_{i}+\gamma \text { Controls }_{i, t}+\lambda_{i}+\phi_{t}+\epsilon_{i, t}
$$

where $V O V_{i, t}$ is the VOV of firm $i$ in fiscal year $t$. Treated $d_{i}$ is a dummy variable that equals one if the firm does not comply with the board independence requirement in fiscal year 2001 and zero otherwise. We determine treatment in 2001 because this is the last year in which board structures are likely to be unaffected by the new listing rules, whereas annual meetings held in 2002 could already have been influenced by the proposals. Post $t_{t}$ is a dummy variable equal to one if the fiscal year is 2002 or later and zero otherwise. Even though the time between

\footnotetext{
${ }^{9}$ The listing rules also contain several additional provisions, including the requirement of fully independent compensation, nominating, and audit committees. Our identification strategy, however, focuses exclusively on the board independence requirement.

${ }^{10}$ Exemptions were only possible for firms with less than 75 million dollars in free-float market capitalization. Since our sample is based on S\&P 1500 firms in the ISS database, it is unlikely that this will play a role in our analysis. Moreover, according to Banerjee et al. (2015), no firms had voluntarily implemented other SOX provisions prior to the law's passage.
} 
the first proposals in 2002 and the final deadlines for compliance in 2004 or 2005 represent a transition phase, we follow Banerjee et al. (2015) and Humphery-Jenner et al. (2019) and choose 2002 as the first post-event year for two reasons. First, about half of the treated firms in our sample had already increased their board independence from 2001 to 2002 and the new incoming independent directors could have immediately influenced the firms' policies. Second, the VOV is a market-based measure and investors can be expected to quickly incorporate new information about a firm's future policy choices. Thus, the (anticipated) change in board structure can plausibly influence the VOV right away. ${ }^{11}$ Figure C.1 in Appendix C illustrates that the mean board independence of the treated sample firms, as well as the fraction of treated firms having an independent board, started to increase immediately after the publication of the first proposals. This steep increase continues during the transition phase. Control firms also slightly increased board independence, yet did so over the course of the whole sample period. The latter should make it harder for us to find a significant effect of the listing rule changes.

We include an array of firm characteristics, summarized under the vector Controls $_{i, t}$, to account for observable time-varying differences between the treated and control firms that might drive the effect on the VOV. ${ }^{12}$ Additionally, all of our models contain firm fixed effects $\left(\lambda_{i}\right)$ to control for unobserved time-invariant firm characteristics, addressing a potential omitted variable bias, as well as year fixed effects $\left(\phi_{t}\right)$ to capture temporal changes in market-wide conditions. ${ }^{13}$ The

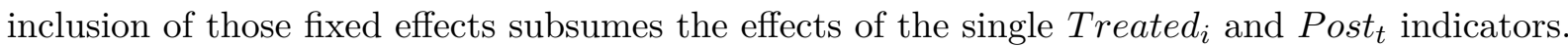
$\epsilon_{i, t}$ is the error term.

Our coefficient of interest is $\beta$, which represents the average change of the difference in the VOV between treated and control firms from before to after the treatment, that is, the DID effect. Based on the argument presented in Section 4.2 , we expect $\beta$ to be negative.

\subsubsection{Propensity score matching}

The key identifying assumption of the DID approach is that treated and control firms follow parallel trends with respect to the outcome of interest before the treatment sets in and that

\footnotetext{
${ }^{11}$ This is a somewhat different situation than in Guo and Masulis (2015), who focus on the effect on forced turnovers. In their case, the new independent directors would first have to enter the board to act, which might explain why they choose 2005 as their first post year. In contrast, in our case the expectation of the increase in independent directors might already influence the VOV. In Section 4.4.3, we also check the robustness of our results by excluding the transition phase from 2002 to 2004 .

${ }^{12}$ We further explain our choice of control variables in Section 4.3.3.

${ }^{13}$ The inclusion of year fixed effects should help to further alleviate concerns that SOX might represent a confounding event.
} 
these parallel trends would have continued if the treatment had not taken place. In our case, that means that both groups can have different levels of VOV as long as their respective VOVs follow the same pattern before the introduction of the new regulation. If, however, treated and control firms differ in characteristics that affect both the choice of an independent board before 2002 and the time trend in the VOV, our DID estimates may be biased.

To alleviate this concern, we conduct a propensity score matching that matches treated firms with similar control firms. In doing so, we generally follow the approach of Guo and Masulis (2015), who, in the same setting as our study, apply radius matching as in Dehejia and Wahba (2002). The advantage of radius matching, as opposed to the nearest neighbor method, is that it increases the number of potential control firms, which can lead to more efficient estimates. Accordingly, we estimate a probit model using data from 1997 to 2000 to predict a firm's propensity score, or its likelihood of not being in compliance with the new regulations in fiscal year 2001. We then take this propensity score to assign one or more control firms to each of the treated ones. More specifically, for each treated firm, we match all firms from the same Fama and French 49 industry whose propensity score falls within a radius (caliper) of 0.15 . This caliper choice is a tradeoff between the quality of the matches and the likelihood that a match cannot be found. We again follow Guo and Masulis (2015) and use 0.15 because it provides a reasonable balance between retaining a high fraction of treated firms and excluding dissimilar potential control firms. For robustness, we also apply calipers of 0.1 and 0.2 and find no significant changes in our results.

In the probit model used to predict the propensity score, we include variables that can be expected to influence both the treatment assignment, that is board structure in 2001, and the VOV. Similar to Guo and Masulis (2015), we employ two sets of control variables. First, we account for each of the three theories of board composition outlined in Boone et al. (2007). Specifically, we include the natural log of total assets to capture the firm's scope of operations; we consider cash holdings, the market-to-book ratio, $\mathrm{R} \& \mathrm{D}$ intensity, and the $\mathrm{E}$ index of Bebchuk et al. (2009) to account for monitoring costs of outsiders and the benefits of private control; and we use CEO-chairperson duality, CEO tenure, and the voting power of inside and linked directors to capture the CEO's influence on the board. Second, we include book leverage and the return on assets as additional firm controls. ${ }^{14}$ The results of the probit model estimation can be found in Table C.2 in Appendix C. In general, the coefficient estimates are in line with prior studies on

\footnotetext{
${ }^{14}$ Note that - just as Guo and Masulis (2015) — we match on observable characteristics only. To account for the potential remaining unobserved differences between the treated and control firms, we include firm fixed effects in our main model from Equation (4.1). We also test several alternative PSM specifications that include a variety of additional controls as robustness checks.
} 
board composition.

\subsubsection{Data and variables}

Our data set is constructed from several well-established databases. We collect data on the board of directors from the ISS database, which begins in 1996 and, therefore, sets the lower bound of our sample. In the base case, our sample period ranges from 1996 to 2015 . $^{15} \mathrm{We}$ obtain daily stock returns, used to calculate our VOV measures, from CRSP, and financial and accounting data from Compustat. Additionally, we collect information on the firms' CEOs from ExecuComp. In line with the literature investigating aspects of board structure and stock market-based measures, we exclude financial firms (SIC Codes 6000-6999) and utilities (SIC Codes 4900-4999) from the data set.

Because of our empirical setting, the firms included in our analyses must meet three additional criteria. First, we only include firms for which we have data on board independence for fiscal year 2001, in which we assign firms to the treated or control group based on whether they comply with the new listing rules or not. Second, we require that firms have at least one observation with full data available after 2001. That is, those firms for which necessary data are only available in the pre-listing rules period are excluded. Third, we require the firms' stock to be listed on the NYSE or NASDAQ from at least 2001 to 2005. Because the final compliance deadlines were in 2004 or 2005, only firms that were still listed at the end of that period were affected. Together, these requirements ensure that we only consider firms to which the new rules actually applied and that our results are not driven by firms that are in the sample only in the pre or post period. Our final matched sample consists of 954 firms, 245 of which are classified as treated. This corresponds to 14,025 firm-year observations in the models containing all control variables.

Our dependent variable of interest is the VOV of stock returns, which we calculate in two different ways. The first approach begins by computing the standard deviation of daily stock returns for each month of the firm's fiscal year. We then calculate the standard deviation of the monthly standard deviations, to obtain the annual $V O V$. We only include months with at least 15 return observations and years with a minimum of six months of return data available on CRSP. This version represents a "raw" VOV measure that picks up the fluctuation of a firm's stock return volatility, independent of its level of volatility. In absolute terms, however, changes in volatility tend to be larger for stocks with high volatility (Baltussen et al., 2018). To account

\footnotetext{
${ }^{15} \mathrm{We}$ also provide results for reduced sample periods in Section 4.4.3.
} 
for this effect, we calculate a second version, the Scaled VOV, similar to that defined in Baltussen et al. (2018), ${ }^{16}$ by simply dividing the raw $V O V$ by the mean of monthly volatilities of a firm's fiscal year. Scaled $V O V$ thus measures the fluctuation of volatility in relation to the level of volatility. For robustness, we also construct idiosyncratic versions of the two VOV measures. Their definitions and the respective results are presented in Section 4.4.8.

In addition to the two main explanatory variables Post and Treated, our models include an array of additional control variables that have been shown to be associated with stock return volatility and firms' risk-related policy choices and, thus, may explain time-varying differences in VOV between treated and control firms. Among them are CEO variables, including a CEO-chairperson indicator, CEO tenure, and CEO ownership ${ }^{17}$, to control for the substantial influence of CEOs on firm policies and outcomes, as well as proxies for several firm characteristics. We control for firm size, leverage, operating performance, cash holdings, R\&D expenditures ${ }^{18}$, and growth opportunities. We also check the robustness of our results by including additional controls. The results are discussed in the robustness section. All variables and their definitions can be found in Table C.1 in Appendix C.

\subsubsection{Descriptive statistics}

Table 4.1 presents the full matched sample summary statistics for both the VOV measures and the control variables used throughout the empirical analyses. Variables obtained from Compustat are winsorized at the $1 \%$ and $99 \%$ level.

To test if the treated firms still differ systematically from the control firms after matching, we also compare the two groups in the year in which we assign the firms to either group. In Table 4.2 , we check for differences in means of important characteristics of the treated and control firms in 2001.

First of all, we can see that the two groups show no statistical differences in the dependent variable, neither in the raw VOV nor in the scaled VOV, which provides initial support for our choice of matching variables. The differences in board independence are, of course, expected.

\footnotetext{
${ }^{16}$ The main difference between our approach and that of Baltussen et al. (2018) is that they use option-implied volatilities. We, instead, use historical volatilities to calculate the VOV, as using implied values would diminish our sample by approximately $50 \%$.

${ }^{17}$ This variable replaces Inside and Linked Vote from the PSM. The latter is not available for the whole sample period and would thus reduce the sample. Our results are robust to using either of the two, Inside and Linked Vote or CEO Ownership, as the control variable throughout the analyses.

${ }^{18}$ In line with the literature, we set missing values for R\&D expenditures to zero (e.g., Coles et al., 2006; Bernile et al., 2018).
} 
Table 4.1: Summary statistics

\begin{tabular}{lcccccc}
\hline & Obs. & Mean & SD & 25th Pct. & Median & 75 th Pct. \\
\hline VOV Measures & & & & & & \\
VOV (\%) & 14122 & 13.592 & 9.052 & 7.516 & 11.249 & 16.906 \\
Scaled VOV (\%) & 14122 & 33.764 & 11.527 & 25.826 & 31.956 & 39.520 \\
\hline Governance and CEO & & & & & & \\
Independence (\%) & 14122 & 71.242 & 16.878 & 60.000 & 75.000 & 85.714 \\
CEO Duality & 14122 & 0.596 & 0.491 & 0.000 & 1.000 & 1.000 \\
CEO Tenure & 14025 & 7.783 & 7.256 & 3.000 & 6.000 & 10.000 \\
CEO Ownership (\%) & 14025 & 1.776 & 5.190 & 0.000 & 0.120 & 0.891 \\
Inside and Linked Vote (\%) & 13598 & 6.683 & 14.692 & 0.000 & 1.500 & 5.840 \\
E Index & 14122 & 2.865 & 1.457 & 2.000 & 3.000 & 4.000 \\
\hline Firm Characteristics & & & & & & \\
Total Assets & 14122 & 8189.431 & 18487.913 & 792.925 & 2027.160 & 6445.000 \\
Book Leverage (\%) & 14122 & 21.812 & 16.135 & 8.566 & 21.117 & 32.189 \\
ROA (\%) & 14122 & 4.938 & 8.652 & 2.360 & 5.651 & 9.263 \\
Cash/Assets (\%) & 14122 & 13.943 & 15.258 & 2.715 & 8.075 & 20.041 \\
R\&D/Assets (\%) & 14122 & 3.160 & 5.011 & 0.000 & 0.537 & 4.276 \\
MTB (\%) & 14122 & 326.287 & 352.529 & 157.114 & 239.670 & 379.610 \\
Firm Age & 14122 & 29.613 & 20.490 & 14.000 & 25.000 & 39.000 \\
\hline
\end{tabular}

Our sample consists of all firm-years with relevant data from the ISS, CRSP, Compustat, and ExecuComp databases during the period between 1996 and 2015. Financial and utility firms are excluded as well as firms without board independence data in 2001 and firms that only appear in the pre listing rules period or that had not been listed on the NYSE or NASDAQ during the full period between 2001 and 2005. Data for Inside and Linked Vote, which we use for the propensity score estimation, are not available in 1996, which explains the lower number of observations. The variables constructed from Compustat data are winsorized at the one and $99 \%$ level. All variable definitions can be found in Table C.1 in Appendix C. 
Table 4.2: Treated vs. control firms in 2001

\begin{tabular}{lcccccc}
\hline & Obs. & Obs. & Mean & Mean & & \\
& Treated & Control & Treated & Control & Difference & $p$-Value \\
\hline VOV (\%) & 245 & 709 & 18.922 & 18.369 & 0.553 & 0.4372 \\
Scaled VOV (\%) & 245 & 709 & 35.241 & 34.759 & 0.482 & 0.5400 \\
Independence (\%) & 245 & 709 & 40.145 & 72.061 & -31.915 & 0.0000 \\
CEO Duality & 245 & 709 & 0.567 & 0.694 & -0.127 & 0.0003 \\
CEO Tenure & 245 & 709 & 8.800 & 6.845 & 1.955 & 0.0003 \\
Inside and Linked Vote (\%) & 245 & 709 & 16.756 & 5.778 & 10.978 & 0.0000 \\
E Index & 245 & 709 & 1.784 & 2.271 & -0.487 & 0.0000 \\
Total Assets & 245 & 709 & 4286.678 & 6187.411 & -1900.733 & 0.0823 \\
Book Leverage (\%) & 245 & 709 & 21.777 & 23.195 & -1.418 & 0.2632 \\
ROA (\%) & 245 & 709 & 3.423 & 1.690 & 1.734 & 0.0224 \\
Cash/Assets (\%) & 245 & 709 & 13.900 & 14.502 & -0.602 & 0.6364 \\
R\&D/Assets (\%) & 245 & 709 & 2.409 & 3.835 & -1.426 & 0.0003 \\
MTB (\%) & 245 & 709 & 314.247 & 324.179 & -9.932 & 0.6841 \\
\hline
\end{tabular}

Our sample includes all non-financial, non-utility firms for which ISS board data are available for 2001 and that meet the additional sample criteria outlined in Section 4.3.3. The treated firms are those that did not have a majority of independent directors on the board in fiscal year 2001, while control firms are the matched firms that met the independence requirement. All remaining variable definitions can be found in Table C.1 in Appendix C. The $p$-values are based on t-test of differences in means. 
With respect to the other matching variables, Shipman et al. (2017) point out that it is unrealistic to expect all differences to be insignificant in large data sets, especially in continuous variables. Rather, the quality of the matching approach should be evaluated on the economic magnitude of the differences. Moreover, in our setting, it is not uncommon to have differences between the treatment and the control group (Guo and Masulis, 2015; Humphery-Jenner et al., 2019). Table 4.2 shows some remaining differences. Compliant firms tend to be smaller, yet only at the $10 \%$ level, and given that we only consider S\&P 1500 firms, the economic effect should be negligible (Banerjee et al., 2015). The two groups also differ according to the two CEO variables. However, the two measures point in opposite directions. CEO duality is more likely in compliant firms, while CEO tenure is more common in noncompliant firms. Moreover, the difference in mean tenure is only two years, which is not likely to make a substantial difference in the power of the CEO. Similarly, the difference in the E index is only half a point, which does not appear to be an economically meaningful difference. The percentage of inside and linked votes is much greater in the treatment group than in the control group. According to Boone et al. (2007), this suggests that insiders have more influence and can avoid control through more independent directors. Conversely, it is also plausible that a greater ownership stake more strongly aligns the directors' interests with those of the shareholders, making control through independent directors less of a necessity. Lastly, we also see statistical differences in performance and R\&D spending, yet, again, the economic magnitude appears to be small. It is thus not immediately clear if these differences will unduly influence our estimations, especially given that they are similar to what prior studies report (e.g., Guo and Masulis, 2015).

Nevertheless, we take several steps to mitigate concerns that this might violate the assumptions of the DID and affect our results. First, we not only include all of these variables as controls in either the main analyses or the robustness checks, but also run all models with firm fixed effects that account for any unobserved or omitted time-invariant firm characteristics. Second, we present a battery of robustness checks in Section 4.4.8, comprising alternative PSM specifications (e.g., in which we directly match on the remaining differences), a different matching approach (i.e., a coarsened exact matching (CEM)), as well as tests for the parallel trends assumption. The results indicate that there are no discernible deviations in pre-treatment trends. Finally, even if there still remained any omitted effects that we cannot include in our econometric model, market participants would include them in pre-event market prices if markets are efficient. That is, these pre-treatment differences are unlikely to drive post-treatment changes in our market-based measure of the VOV (Duchin et al., 2010). In summary, we remain confident that the data are 
suited for a DID approach.

\subsection{Results}

\subsubsection{Initial evidence of the effect on the VOV}

To test our expectation that greater board independence reduces the VOV, we conduct an array of analyses that will be presented in the following sections. We start with a brief univariate DID analysis that provides a first indication of whether the change in board structure influences the VOV of the affected firms, and if so, how. We take the matched sample and compare the mean VOV of the treated firms against that of the control firms before and after the change. Table 4.3 illustrates the results for $\operatorname{VOV}$ (Panel A) as well as for Scaled VOV (Panel B).

Table 4.3: Univariate DID

\begin{tabular}{lcc}
\hline Panel A: VOV (\%) & Pre & Post \\
\hline Treated & 16.3318 & 12.5181 \\
Control & 15.0308 & 12.8730 \\
Difference & $1.301^{* * *}$ & $-0.3549^{*}$ \\
DID & & $\mathbf{- 1 . 6 5 5 9 * *}$ \\
\hline Panel B: Scaled VOV (\%) & & \\
& Pre & Post \\
\hline Treated & 33.2998 & 34.1934 \\
Control & 31.9865 & 34.5181 \\
Difference & $1.3133^{* * *}$ & -0.3248 \\
DID & & $\mathbf{- 1 . 6 3 8 1 * * *}$ \\
\hline
\end{tabular}

This table presents univariate DID analyses that compare the means of VOV (Panel A) and Scaled VOV (Panel $\mathrm{B})$ of the treated and the control firms before and after the introduction of the new listing requirements. The analysis is performed on the matched sample. Pre and Post specify the pre- and post-treatment periods, with *, $* *$, and $* * *$ indicating significance levels of $10 \%, 5 \%$, and $1 \%$, respectively, for t-tests of differences between means.

In both panels, we find that, in the period before the introduction of the new regulation, treated firms on average exhibited a significantly greater VOV than did their counterparts that had already met the independence requirement. This difference, however, all but vanishes in the post-treatment period, with the difference in the Scaled VOV becoming insignificant and that for the VOV falling to the $10 \%$ level. Consequently, the DID effect is negative and highly statistically significant for both VOV measures. Furthermore, the effect appears to be economically significant. Considering a mean (median) VOV of the treated firms of $16.33 \%(14.13 \%)$ in the pre-treatment period, the DID estimate of $-1.66 \%$ implies - all else being equal - a decrease in the VOV of $10.17 \%$ (11.75\%). With respect to the Scaled VOV, the estimate of $-1.64 \%$ suggests a decrease of $4.92 \%(5.17 \%)$ compared to the mean (median) of $33.30 \%(31.70 \%)$ in the pre-treatment period. 
Although these univariate tests do not account for any further observed or unobserved differences between the treated and control firms that might explain this finding, they point toward the expected result that increased board independence decreases the VOV. Moreover, these results indicate a convergence of the treated firms, whose volatility previously exhibited significantly higher fluctuations, with the control firms.

\subsubsection{Effect of board structure on the VOV}

To get a better understanding of the effect that board independence has on the VOV, we next use the matched sample and conduct multivariate analyses that account for time-varying observed and unobserved differences between the treated and control firms. We use Equation (4.1) to estimate the effect of board structure on the VOV.

We perform the estimations for both VOV measures, VOV and Scaled VOV, which serve as the dependent variables. For each, we estimate two models that include different subsets of controls: one that includes the CEO controls and one that does not. Since variables that are affected by the treatment itself should not be used as controls in the DID model (Roberts and Whited, 2013) ${ }^{19}$ and since the CEO controls represent aspects of corporate governance that might interact with board independence, we check whether including them influences our estimations. Table 4.4 presents the results. Standard errors are always clustered on the firm level throughout our analyses.

In line with our expectation, we find negative and highly statistically significant coefficient estimates for the interaction terms in all four models. The results in Columns (1) and (2) show that this holds for $V O V$, whereas Columns (3) and (4) illustrate the same for Scaled VOV. Thus, the increase in board independence leads to a decrease in the VOV of the treated firms compared to their counterparts that already had majority independent boards.

The effect of board structure on the VOV is also meaningful economically. For example, the coefficient estimate of -1.04 in Column (2) indicates that, on average, the difference in $V O V$ between the treated and the control firms decreased by about one percentage point. Given that the mean (median) VOV of the treated firms before the listing rule changes is $16.33 \%(14.13 \%)$, this implies that - all else being equal - the increase in board independence leads to a VOV decrease of about $6.37 \%$ (7.36\%). Similarly, based on the estimate of $-1.60 \%$ in Column (4) and

\footnotetext{
${ }^{19}$ This is also the reason why, for example, we do not include board size as a control variable, as it is very likely to be directly affected by the listing rule changes (Linck et al., 2009).
} 
Table 4.4: Effect of board structure on the VOV

\begin{tabular}{|c|c|c|c|c|}
\hline & \multicolumn{2}{|c|}{ VOV } & \multicolumn{2}{|c|}{ Scaled VOV } \\
\hline & $\begin{array}{c}(1) \\
\text { VOV }\end{array}$ & $\begin{array}{c}(2) \\
\text { VOV }\end{array}$ & $\begin{array}{c}(3) \\
\text { Scaled VOV }\end{array}$ & $\begin{array}{c}(4) \\
\text { Scaled VOV }\end{array}$ \\
\hline Post $\times$ Treated & $\begin{array}{c}-1.0821^{* * *} \\
(0.0062)\end{array}$ & $\begin{array}{c}-1.0402^{* * *} \\
(0.0092)\end{array}$ & $\begin{array}{c}-1.5127^{* * *} \\
(0.0032)\end{array}$ & $\begin{array}{c}-1.5966^{* * *} \\
(0.0021)\end{array}$ \\
\hline CEO Duality & & $\begin{array}{l}0.3841^{*} \\
(0.0534)\end{array}$ & & $\begin{array}{c}0.1063 \\
(0.7099)\end{array}$ \\
\hline Ln(1+CEO Tenure $)$ & & $\begin{array}{c}-0.2597^{* *} \\
(0.0280)\end{array}$ & & $\begin{array}{l}-0.1818 \\
(0.3009)\end{array}$ \\
\hline CEO Ownership & & $\begin{array}{c}0.0032 \\
(0.8725)\end{array}$ & & $\begin{array}{l}-0.0171 \\
(0.5359)\end{array}$ \\
\hline Ln(Total Assets) & $\begin{array}{c}-1.2936^{* * *} \\
(0.0000)\end{array}$ & $\begin{array}{c}-1.2944^{* * *} \\
(0.0000)\end{array}$ & $\begin{array}{c}0.3089 \\
(0.2659)\end{array}$ & $\begin{array}{c}0.3516 \\
(0.1989)\end{array}$ \\
\hline Book Leverage & $\begin{array}{c}0.0175^{* *} \\
(0.0465)\end{array}$ & $\begin{array}{c}0.0170^{* *} \\
(0.0496)\end{array}$ & $\begin{array}{c}0.0290^{* *} \\
(0.0135)\end{array}$ & $\begin{array}{c}0.0258^{* *} \\
(0.0272)\end{array}$ \\
\hline ROA & $\begin{array}{c}-0.2200^{* * * *} \\
(0.0000)\end{array}$ & $\begin{array}{c}-0.2183^{* * *} \\
(0.0000)\end{array}$ & $\begin{array}{c}-0.0861^{* * *} \\
(0.0000)\end{array}$ & $\begin{array}{c}-0.0852^{* * * *} \\
(0.0000)\end{array}$ \\
\hline Cash/Assets & $\begin{array}{c}0.0299^{* * *} \\
(0.0043)\end{array}$ & $\begin{array}{c}0.0306^{* * *} \\
(0.0034)\end{array}$ & $\begin{array}{l}-0.0080 \\
(0.5549)\end{array}$ & $\begin{array}{l}-0.0096 \\
(0.4814)\end{array}$ \\
\hline R\&D/Assets & $\begin{array}{l}-0.0221 \\
(0.6671)\end{array}$ & $\begin{array}{l}-0.0117 \\
(0.8181)\end{array}$ & $\begin{array}{c}0.0680 \\
(0.2613)\end{array}$ & $\begin{array}{c}0.0789 \\
(0.1951)\end{array}$ \\
\hline MTB & $\begin{array}{l}-0.0000 \\
(0.9609)\end{array}$ & $\begin{array}{c}0.0000 \\
(0.9211)\end{array}$ & $\begin{array}{c}-0.0012^{* * *} \\
(0.0010)\end{array}$ & $\begin{array}{c}-0.0012^{* * *} \\
(0.0016)\end{array}$ \\
\hline Firm Fixed Effects & Yes & Yes & Yes & Yes \\
\hline Year Fixed Effects & Yes & Yes & Yes & Yes \\
\hline Sample Size & 14,122 & 14,025 & 14,122 & 14,025 \\
\hline Adj. R-Squared & 0.3735 & 0.3748 & 0.1447 & 0.1461 \\
\hline
\end{tabular}

This table presents the coefficient estimates from regressions of $V O V$ and Scaled $V O V$, respectively, on the DID interaction term and different subsets of control variables. Each regression is performed on the matched sample. Post is a dummy variable equal to one if the fiscal year is 2002 or later and zero otherwise. Treated is a dummy variable equal to one if a firm does not comply with the board independence requirement in fiscal year 2001 and zero otherwise. Definitions for the remaining variables can be found in Table C.1 in Appendix C. All models include firm and year fixed effects, as well as a constant term. The $p$-values are based on standard errors clustered at the firm-level and are reported in parentheses, with *, ${ }^{* *}$, and $* * *$ indicating significance levels of $10 \%, 5 \%$, and $1 \%$, respectively. 
considering a mean (median) of $33.30 \%(31.70 \%)$ the decrease in Scaled VOV would be $4.80 \%$ (5.05\%). Since the effect is similar in both statistic and economic significance and because our scaled VOV measure accounts for the level of volatility, we will henceforth focus on the Scaled VOV.

Estimates of the control variables reveal that larger and more profitable firms experience less volatile stock price risk, whereas those that are highly leveraged have a higher VOV. Furthermore, adding the CEO controls has a small effect on the results, as evidenced by the almost identical coefficient estimates, significance levels, and adjusted $R^{2} \mathrm{~s}$ of both models. Nevertheless, since they do capture effects on the VOV to some extent, the focus of our explanations in the remainder of the paper will be on the models that include all the variables.

Overall, these results provide strong evidence in favor of our expectation that increased board independence reduces the VOV of the affected firms.

\subsubsection{Do specific time periods drive the results?}

We next check whether the results are driven by specific time periods that are included in our sample. We address the following three concerns. First, our main analysis considers a rather long period following the introduction of the new listing requirements, which increases the risk of confounding events in later years. To address this, we re-estimate our models using only years 1996 to 2007 . We choose this alternative period because it yields equal pre- and post-event samples of six years each and it ends before the financial crisis sets in.

Second, our central analysis defines the transition period between 2002 and 2004 (i.e., the time when the new regulations had been made public information, but the actual deadlines for compliance had not yet been reached) as part of the "post years". In other words, we assume that the change in board structure occurred instantaneously, which is obviously not the case. Several firms adjusted their board structure step by step ${ }^{20}$, which might obscure the treatment effect. To mitigate this concern, we re-run our analyses, but we exclude the transition period.

Third, our sample also includes the 2008-2009 financial crisis, which saw a surge not only in volatility, but also in market-wide VOV (Huang et al., 2019). If during that time, both treated and control firms exhibited exceptionally high VOV, it is conceivable that their VOVs became more alike on a high level and that the reduction of the difference in VOV between the treated

\footnotetext{
${ }^{20}$ Figure C.1 in Appendix C illustrates that the major increase in the treated firms' board independence happened gradually during the transition phase.
} 
and control firms is mainly a result of this market-wide effect. To test this, we re-estimate our models without the fiscal years 2008 and $2009 .{ }^{21}$

For each of the three scenarios, we again estimate the two versions of the model that contain the different subsets of controls. Table 4.5 reports the results.

\footnotetext{
${ }^{21}$ We obtain the same results when we exclude the years 2007 to 2009.
} 
Table 4.5: Do specific time periods drive the results?

\begin{tabular}{|c|c|c|c|c|c|c|}
\hline & \multicolumn{2}{|c|}{$\begin{array}{l}\text { Reduced sample } \\
\quad(1996-2007)\end{array}$} & \multicolumn{2}{|c|}{$\begin{array}{l}\text { Excl. transition phase } \\
\quad(2002-2004)\end{array}$} & \multicolumn{2}{|c|}{$\begin{array}{l}\text { Excl. financial crisis } \\
\quad(2008-2009)\end{array}$} \\
\hline & $\begin{array}{c}(1) \\
\text { Scaled VOV }\end{array}$ & $\begin{array}{c}(2) \\
\text { Scaled VOV }\end{array}$ & $\begin{array}{c}(3) \\
\text { Scaled VOV }\end{array}$ & $\begin{array}{c}(4) \\
\text { Scaled VOV }\end{array}$ & $\begin{array}{c}(5) \\
\text { Scaled VOV }\end{array}$ & $\begin{array}{c}(6) \\
\text { Scaled VOV }\end{array}$ \\
\hline Post $\times$ Treated & $\begin{array}{c}-1.5919^{* * *} \\
(0.0040)\end{array}$ & $\begin{array}{c}-1.7893^{* * *} \\
(0.0012)\end{array}$ & $\begin{array}{c}-1.4897^{* *} \\
(0.0123)\end{array}$ & $\begin{array}{c}-1.6282^{* * *} \\
(0.0061)\end{array}$ & $\begin{array}{c}-1.4681^{* * *} \\
(0.0057)\end{array}$ & $\begin{array}{c}-1.5918^{* * *} \\
(0.0030)\end{array}$ \\
\hline CEO Duality & & $\begin{array}{c}0.2197 \\
(0.5369)\end{array}$ & & $\begin{array}{c}0.0773 \\
(0.8071)\end{array}$ & & $\begin{array}{c}0.2352 \\
(0.4356)\end{array}$ \\
\hline Ln(1+CEO Tenure $)$ & & $\begin{array}{l}-0.0947 \\
(0.6640)\end{array}$ & & $\begin{array}{l}-0.1357 \\
(0.4818)\end{array}$ & & $\begin{array}{l}-0.2335 \\
(0.2140)\end{array}$ \\
\hline CEO Ownership & & $\begin{array}{l}-0.0343 \\
(0.2800)\end{array}$ & & $\begin{array}{l}-0.0051 \\
(0.8838)\end{array}$ & & $\begin{array}{l}-0.0299 \\
(0.2900)\end{array}$ \\
\hline Ln(Total Assets) & $\begin{array}{c}0.1085 \\
(0.7842)\end{array}$ & $\begin{array}{c}0.0682 \\
(0.8666)\end{array}$ & $\begin{array}{c}0.1902 \\
(0.5110)\end{array}$ & $\begin{array}{c}0.2453 \\
(0.3944)\end{array}$ & $\begin{array}{c}0.2250 \\
(0.4452)\end{array}$ & $\begin{array}{c}0.2516 \\
(0.3837)\end{array}$ \\
\hline Book Leverage & $\begin{array}{c}0.0441^{* * *} \\
(0.0049)\end{array}$ & $\begin{array}{c}0.0386^{* *} \\
(0.0120)\end{array}$ & $\begin{array}{l}0.0256^{*} \\
(0.0537)\end{array}$ & $\begin{array}{l}0.0224^{*} \\
(0.0910)\end{array}$ & $\begin{array}{c}0.0328^{* *} \\
(0.0114)\end{array}$ & $\begin{array}{c}0.0301^{* *} \\
(0.0197)\end{array}$ \\
\hline ROA & $\begin{array}{c}-0.0695^{* * *} \\
(0.0007)\end{array}$ & $\begin{array}{c}-0.0700^{* * *} \\
(0.0006)\end{array}$ & $\begin{array}{c}-0.0816^{* * *} \\
(0.0000)\end{array}$ & $\begin{array}{c}-0.0810^{* * *} \\
(0.0001)\end{array}$ & $\begin{array}{c}-0.0783^{* * *} \\
(0.0000)\end{array}$ & $\begin{array}{c}-0.0762^{* * *} \\
(0.0000)\end{array}$ \\
\hline Cash/Assets & $\begin{array}{c}-0.0149 \\
(0.3568)\end{array}$ & $\begin{array}{l}-0.0148 \\
(0.3709)\end{array}$ & $\begin{array}{l}-0.0044 \\
(0.7760)\end{array}$ & $\begin{array}{c}-0.0061 \\
(0.6964)\end{array}$ & $\begin{array}{c}-0.0067 \\
(0.6290)\end{array}$ & $\begin{array}{l}-0.0081 \\
(0.5630)\end{array}$ \\
\hline $\mathrm{R} \& \mathrm{D} /$ Assets & $\begin{array}{c}0.0454 \\
(0.4750)\end{array}$ & $\begin{array}{c}0.0594 \\
(0.3513)\end{array}$ & $\begin{array}{c}0.0499 \\
(0.4610)\end{array}$ & $\begin{array}{c}0.0619 \\
(0.3607)\end{array}$ & $\begin{array}{c}0.0853 \\
(0.1777)\end{array}$ & $\begin{array}{c}0.0981 \\
(0.1218)\end{array}$ \\
\hline MTB & $\begin{array}{c}-0.0016^{* * * *} \\
(0.0008)\end{array}$ & $\begin{array}{c}-0.0016^{* * * *} \\
(0.0019)\end{array}$ & $\begin{array}{c}-0.0011^{* *} \\
(0.0111)\end{array}$ & $\begin{array}{c}-0.0010^{* *} \\
(0.0125)\end{array}$ & $\begin{array}{c}-0.0013^{* * *} \\
(0.0008)\end{array}$ & $\begin{array}{c}-0.0012^{* * * *} \\
(0.0018)\end{array}$ \\
\hline Firm Fixed Effects & Yes & Yes & Yes & Yes & Yes & Yes \\
\hline Year Fixed Effects & Yes & Yes & Yes & Yes & Yes & Yes \\
\hline Sample Size & 9,378 & 9,303 & 11,446 & 11,360 & 12,818 & 12,727 \\
\hline Adj. R-Squared & 0.0652 & 0.0648 & 0.1473 & 0.1493 & 0.0737 & 0.0741 \\
\hline
\end{tabular}

This table presents the coefficient estimates from regressions of Scaled VOV on the DID interaction term and different subsets of control variables for different sample periods. In Columns (1) and (2) the sample period is from 1996 to 2007, in Columns (3) and (4) the years 2002 to 2004, and in Columns (5) and (6) the years 2008 and 2009 are excluded. Each regression is performed on the matched sample. Post is a dummy variable equal to one if the fiscal year is 2002 or later and zero otherwise. Treated is a dummy variable equal to one if a firm does not comply with the board independence requirement in fiscal year 2001 and zero otherwise. Definitions for the remaining variables can be found in Table C.1 in Appendix C. All models include firm and year fixed effects, as well as a constant term. The $p$-values are based on standard errors clustered at the firm-level and are reported in parentheses, with *, **, and *** indicating significance levels of $10 \%, 5 \%$, and $1 \%$, respectively. 
The results for the reduced sample period are provided in Columns (1) and (2), for the periods excluding the transition phase in Columns (3) and (4), and those excluding the years of the financial crisis in Columns (5) and (6). In all the models, the coefficients on the interaction terms are negative and statistically significant with $p$-values below the $1 \%$ level, except for Column (3), which is significant at the $5 \%$ level. Furthermore, the coefficients are somewhat higher than in the baseline models when the sample period is shortened. When the transition phase or the financial crisis is excluded, the coefficients remain virtually the same. Our results, therefore, do not appear to be driven by the choice of the sample period or the inclusion or exclusion of particular time periods. In summary, the results presented in this section further strengthen our finding of a reducing effect of the new board independence requirement on the VOV of the affected firms.

\subsubsection{Do certain firm characteristics matter?}

After having illustrated the reducing effect of the listing rule changes on the VOV, we next test if this baseline effect is conditional on particular cross-sectional differences that existed between treated firms prior to the event. It is possible that dynamics within specific firms have an impact on the oversight function carried out by the independent directors. Therefore, we examine several firm characteristics that could potentially affect the independent directors' effectiveness. In particular, we analyze the moderating effect of further CEO and board dynamics, external governance, and the fundamental riskiness of the firm.

We start with CEO power for which we use two common measures: CEO-chair duality and CEO tenure. More powerful CEOs may be able to withstand pressure from the board to change their investment strategies. Next, we consider board size and the degree of co-option, which have been shown to affect board effectiveness (Yermack, 1996; Cheng, 2008; Coles et al., 2014). ${ }^{22}$ Additionally, we use the E index to check for a potential moderating effect of external governance (Cremers and Nair, 2005). Finally, the ratio of R\&D expenditures to assets serves as the proxy for the level of fundamental firm risk (Kothari et al., 2002). High risk firms may be even harder for outsiders to evaluate and thus, independent directors might feel a greater urge to reduce the VOV.

To test for moderating effects of these firm characteristics empirically we re-estimate our initial

\footnotetext{
${ }^{22}$ Even though newly appointed directors are, by definition, co-opted as well, the high demand and the reduced pool of available candidates during the time of the introduction of the board independence requirement (Linck et al., 2009) most likely made it harder for CEOs to still find directors they could co-opt.
} 
model, while splitting the treatment effect. More precisely, we take Equation (4.1) and replace the initial interaction with two triple interaction terms in which we add dummy variables that indicate whether a firm exhibits high or low values for the respective characteristic in the pre-treatment period. The modified model then looks as follows:

$$
\begin{aligned}
\text { VOV }_{i, t}= & \alpha+\beta_{1} \text { Post }_{t} \times \text { Treated }_{i} \times \text { High }_{i}+\beta_{2} \text { Post }_{t} \times \text { Treated }_{i} \times \text { Low }_{i} \\
& +\gamma \text { Controls }_{i, t}+\lambda_{i}+\phi_{t}+\epsilon_{i, t}
\end{aligned}
$$

where $\operatorname{High}_{i}\left(\operatorname{Low}_{i}\right)$ is a dummy variable equal to one if the treated firm's average value for the respective characteristic during the years 1998-2001 is above (below or equal to) the median average value among the treated firms and zero otherwise. The rest of the variables are the same as in Equation (4.1). Just as in our main analysis, the coefficients on both interaction terms represent the average change of the difference in VOV between the treated and the control firms from before to after the change in regulation. This effect, however, is now separated along the particular characteristics of interest. Table 4.6 presents the results. We only present the results for the full model, since they have a slightly higher adjusted $R^{2}$. The results for the reduced model are nearly identical. For brevity, the coefficient estimates for the control variables are omitted. 
Table 4.6: Further firm characteristics that matter

\begin{tabular}{|c|c|c|c|c|c|c|}
\hline & $\begin{array}{c}(1) \\
\text { Scaled VOV }\end{array}$ & $\begin{array}{c}(2) \\
\text { Scaled VOV }\end{array}$ & $\begin{array}{c}(3) \\
\text { Scaled VOV }\end{array}$ & $\begin{array}{c}(4) \\
\text { Scaled VOV }\end{array}$ & $\begin{array}{c}(5) \\
\text { Scaled VOV }\end{array}$ & $\begin{array}{c}(6) \\
\text { Scaled VOV }\end{array}$ \\
\hline Post $\times$ Treated $\times$ CEO Duality High & $\begin{array}{c}-1.6031^{* *} \\
(0.0270)\end{array}$ & & & & & \\
\hline Post $\times$ Treated $\times$ CEO Duality Low & $\begin{array}{c}-1.5916^{* *} \\
(0.0159)\end{array}$ & & & & & \\
\hline Post $\times$ Treated $\times$ CEO Tenure High & & $\begin{array}{c}-2.1224^{* * *} \\
(0.0011)\end{array}$ & & & & \\
\hline Post $\times$ Treated $\times$ CEO Tenure Low & & $\begin{array}{l}-0.9559 \\
(0.1974)\end{array}$ & & & & \\
\hline Post $\times$ Treated $\times$ Board Size High & & & $\begin{array}{c}-1.1890^{*} \\
(0.0625)\end{array}$ & & & \\
\hline Post $\times$ Treated $\times$ Board Size Low & & & $\begin{array}{l}-2.0758^{* * *} \\
(0.0058)\end{array}$ & & & \\
\hline Post $\times$ Treated $\times$ Co-Option High & & & & $\begin{array}{c}-1.6902^{* *} \\
(0.0233)\end{array}$ & & \\
\hline Post $\times$ Treated $\times$ Co-Option Low & & & & $\begin{array}{c}-1.4231^{* *} \\
(0.0469)\end{array}$ & & \\
\hline Post $\times$ Treated $\times$ E Index High & & & & & $\begin{array}{c}-1.8146^{* *} \\
(0.0253)\end{array}$ & \\
\hline Post $\times$ Treated $\times$ E Index Low & & & & & $\begin{array}{c}-1.5106^{* *} \\
(0.0134)\end{array}$ & \\
\hline Post $\times$ Treated $\times$ R\&D/Assets High & & & & & & $\begin{array}{c}-1.5641^{* *} \\
(0.0252)\end{array}$ \\
\hline Post $\times$ Treated $\times \mathrm{R} \& \mathrm{D} /$ Assets Low & & & & & & $\begin{array}{c}-1.6201^{* *} \\
(0.0164)\end{array}$ \\
\hline CEO Controls & Yes & Yes & Yes & Yes & Yes & Yes \\
\hline Firm Controls & Yes & Yes & Yes & Yes & Yes & Yes \\
\hline Firm Fixed Effects & Yes & Yes & Yes & Yes & Yes & Yes \\
\hline Year Fixed Effects & Yes & Yes & Yes & Yes & Yes & Yes \\
\hline Sample Size & 14,025 & 14,025 & 14,025 & 13,555 & 14,025 & 14,025 \\
\hline Adj. R-Squared & 0.1461 & 0.1462 & 0.1462 & 0.1463 & 0.1461 & 0.1461 \\
\hline
\end{tabular}

This table presents the coefficient estimates from regressions in which we separate the treatment effect along several pre-treatment cross-sectional differences that could potentially moderate the effect on the Scaled VOV. Each regression is performed on the matched sample. Post is a dummy variable equal to one if the fiscal year is 2002 or later and zero otherwise. Treated is a dummy variable equal to one if a firm does not comply with the board independence requirement in fiscal year 2001 and zero otherwise. For each dimension, High ( Low) is a dummy variable equal to one if a treated firm's average value for the respective characteristic during the years $1998-2001$ is above (equal or above) the median average value among the treated firms and zero otherwise. Definitions for the remaining variables can be found in Table C.1 in Appendix C. All models include firm and year fixed effects, as well as a constant term. The $p$-values are based on standard errors clustered at the firm-level and are reported in parentheses, with *, $* *$, and $* * *$ indicating significance levels of $10 \%, 5 \%$, and $1 \%$, respectively. 
The results show that, for nearly all the firm characteristics considered in this analysis, the baseline DID effect occurs in both groups of treated firms - high and low - and with very similar magnitudes. CEO tenure in Column (2) represents the only exception, as the effect is only significant for treated firms that have CEOs with above-median tenure. This could indicate that independent directors intervene more forcefully in these firms so that more powerful CEOs are controlled more strongly. For all other tests, however, the VOV reduction occurs in both groups of treated firms by similar amounts, as indicated by similar coefficient estimates and significance levels. Interestingly, the effect is somewhat stronger economically and statistically for firms with smaller boards, as shown in Column (6), supporting the view that smaller boards can monitor more effectively. With respect to the fundamental riskiness of the firm, we again see an almost equal VOV reduction in both groups. In an unreported analysis, we use the market-to-book ratio as an alternative risk proxy (Griffin and Lemmon, 2002) and find that the effect also occurs in both groups, yet appears to be statistically and economically somewhat stronger in the low-risk group.

Taken together, the overall results in this section strongly suggest that the effect does not depend on internal firm characteristics such as further CEO and board dynamics, external governance, or the fundamental riskiness of the firm.

\subsubsection{Do information asymmetry and stock liquidity matter?}

In this section, we test if the VOV reduction is greater in firms where ambiguity is conceivably more detrimental to investors, which we suspect to be the case when firms experience greater information asymmetry and lower liquidity. Our baseline assumption is that ambiguity exists when shareholders and even professional analysts cannot fully understand the strategies that management has implemented (Litov et al., 2012). In the case of information asymmetry, outsiders have considerably less information than do insiders, which already makes it harder for them to evaluate the firm and the actions of the managers. Ambiguity is especially troublesome for shareholders of firms in such circumstances, as it makes it even more difficult to evaluate the firm based on the limited information that they do receive (Williams, 2014). So, while we expect that the VOV will be reduced in all firms, we surmise that the changes in board structure will lead to a stronger reduction of the VOV in these firms. With respect to liquidity, Easley and O'Hara (2009) theoretically predict, and Baltussen et al. (2018) empirically show, that ambiguity leads investors to refrain from trading in the stock, lowering its liquidity. Therefore, a greater need exists to improve stock liquidity in these firms. We expect that in firms with lower liquidity, 
independent directors will effect greater reductions in the VOV to improve the tradability of stocks.

To test if the effect is stronger in firms afflicted by information asymmetry and/or stock illiquidity, we conduct an analysis similar to that of the previous section. That is, we split the treatment effect according to three different measures, proxying for information asymmetry and liquidity. First, we use analyst forecast inaccuracy, which we calculate as the absolute difference between actual and forecasted earnings per share from I/B/E/S, divided by the absolute value of actual earnings per share. Second, we calculate the bid-ask spread according to Balakrishnan et al. (2014), which is used both as a proxy for information asymmetry and for liquidity. Third, we use Amihud's (2002) illiquidity measure. As in the previous section, we use the median average values for the years 1998-2001 to assign treated firms to high and low groups in the respective characteristic. The results are presented in Table 4.7. 
Table 4.7: Effect of information asymmetry and stock liquidity

\begin{tabular}{|c|c|c|c|c|c|c|}
\hline & $\begin{array}{c}(1) \\
\text { Scaled VOV }\end{array}$ & $\begin{array}{c}(2) \\
\text { Scaled VOV }\end{array}$ & $\begin{array}{c}(3) \\
\text { Scaled VOV }\end{array}$ & $\begin{array}{c}(4) \\
\text { Scaled VOV }\end{array}$ & $\begin{array}{c}(5) \\
\text { Scaled VOV }\end{array}$ & $\begin{array}{c}(6) \\
\text { Scaled VOV }\end{array}$ \\
\hline Post $\times$ Treated $\times$ Forecast Inaccuracy High & $\begin{array}{c}-1.8058^{* *} \\
(0.0106)\end{array}$ & $\begin{array}{c}-1.7725^{* *} \\
(0.0144)\end{array}$ & & & & \\
\hline Post $\times$ Treated $\times$ Forecast Inaccuracy Low & $\begin{array}{l}-0.9852 \\
(0.1386)\end{array}$ & $\begin{array}{r}-1.1987^{*} \\
(0.0660)\end{array}$ & & & & \\
\hline Post $\times$ Treated $\times$ Bid-Ask High & & & $\begin{array}{c}-2.3461^{* * *} \\
(0.0005)\end{array}$ & $\begin{array}{c}-2.2990^{* * *} \\
(0.0008)\end{array}$ & & \\
\hline Post $\times$ Treated $\times$ Bid-Ask Low & & & $\begin{array}{l}-0.5954 \\
(0.3897)\end{array}$ & $\begin{array}{l}-0.8232 \\
(0.2309)\end{array}$ & & \\
\hline Post $\times$ Treated $\times$ Amihud Illiquidity High & & & & & $\begin{array}{c}-2.3622^{* * *} \\
(0.0021)\end{array}$ & $\begin{array}{c}-2.3484^{* * *} \\
(0.0027)\end{array}$ \\
\hline Post $\times$ Treated $\times$ Amihud Illiquidity Low & & & & & $\begin{array}{l}-0.7938 \\
(0.1932)\end{array}$ & $\begin{array}{l}-0.9674 \\
(0.1095)\end{array}$ \\
\hline CEO Controls & No & Yes & No & Yes & No & Yes \\
\hline Firm Controls & Yes & Yes & Yes & Yes & Yes & Yes \\
\hline Firm Fixed Effects & Yes & Yes & Yes & Yes & Yes & Yes \\
\hline Year Fixed Effects & Yes & Yes & Yes & Yes & Yes & Yes \\
\hline Sample Size & 13,889 & 13,793 & 14,122 & 14,025 & 14,122 & 14,025 \\
\hline Adj. R-Squared & 0.1458 & 0.1473 & 0.1449 & 0.1463 & 0.1449 & 0.1463 \\
\hline
\end{tabular}

This table presents the coefficient estimates from regressions in which we separate the treatment effect along information asymmetry and liquidity dimensions that we expect to moderate the effect on the Scaled VOV. Each regression is performed on the matched sample. Post is a dummy variable equal to one if the fiscal year is 2002 or later and zero otherwise. Treated is a dummy variable equal to one if a firm does not comply with the board independence requirement in fiscal year 2001 and zero otherwise. For each dimension, High (Low) is a dummy variable equal to one if a treated firm's mean value in this dimension for the years 1998-2001 is above (equal or above) the median among the treated firms. Definitions for the remaining variables can be found in Table C.1 in Appendix C. All models include firm and year fixed effects, as well as a constant term. The $p$-values are based on standard errors clustered at the firm-level and are reported in parentheses, with *, $* *$, and $* * *$ indicating significance levels of $10 \%, 5 \%$, and $1 \%$, respectively. 
The results all support the notion that firms with the greatest information asymmetry and/or stock illiquidity experience the greatest reduction in the VOV. First, the effect is highly significant in these cases. In contrast, we see a lower significance level in cases of lower analyst forecast errors and no significance in firms with higher liquidity. Second, the coefficients are greater than in our baseline estimates, which suggests that, as expected, the change in board independence leads to greatest VOV reductions in firms where it is most difficult for outsiders, both shareholders and analysts, to form a solid evaluation of the firm and where the liquidity is lowest. Consistent with our expectation, the effect of enhanced board oversight is thus greater in firms that are more negatively impacted by ambiguity.

\subsubsection{Policy stability as a channel}

So far, we have shown that board structure affects the VOV and that this impact is largely independent of several firm characteristics. We next focus on the channels through which board independence can potentially influence a firm's VOV.

Our main argument about how board structure affects the VOV is that improved board monitoring should lead to firm policies that are more stable and easier to understand, which, in turn, should reduce ambiguity. Therefore, we look at several risk-related firm policies that, if they are volatile, might be difficult for outsiders to understand and evaluate. Then, we examine if the change in board structure leads to greater stability (i.e., smaller deviations or variances) in these policies. In particular, we consider the firms' major investment policies, that is capital expenditures, R\&D expenditures, and acquisition expenses, which we examine individually and in two aggregated measures (total and net investment ${ }^{23}$ ). We also examine PPE, which serves as an important collateral channel (Norden and van Kampen, 2013), cash holdings, which are sometimes held to reduce risk (Opler et al., 1999), and market leverage, which can affect volatility (Schwert, 1989). The definitions of the variables that are used to calculate our proxies for policy changes can be found in Table C.1 in Appendix C.

To analyze if these policies became more stable (i.e., exhibit smaller variances or deviations) over time, we define two proxies for each of the policy measures under investigation. The first represents the change from one fiscal year to another and is calculated as the absolute value of the difference in a policy's value between periods $t$ and $t-1$. We use the absolute change, because a $10 \%$ increase in a firm's volatility induced by an increase in risk-related firm policies will have

\footnotetext{
${ }^{23}$ We define total investment as the sum of capital expenditures, R\&D expenditures, and acquisition expenses, while net investment is total investment less sale of PPE.
} 
the same effect on the VOV as a $10 \%$ decrease. Hence, the more a firm deviates - positively or negatively - from its prior policy, the more the VOV should increase. Conversely, smaller deviations in a firm's policies should decrease the firm's VOV.

Since we calculate our VOV measures from changes in monthly stock return volatility within a year, we would ideally use policy measures that are also based on monthly observations. Unfortunately, such data are not available, so we utilize quarterly data obtained from Compustat to calculate our second proxy for corporate policy changes. More precisely, for each firm-year, we calculate the annualized standard deviation of the quarterly values of the respective policy variable. ${ }^{24}$ This quarterly standard deviation should provide a better picture of how, for example, $\mathrm{R} \& \mathrm{D}$ expenditures fluctuate within the year.

We then take each of these measures as the dependent variable and re-estimate our initial model from Equation (4.1) to assess the effect of the treatment on the changes in the respective corporate policies. If, as we suspect, these policies become more stable, we would expect to see negative coefficient estimates on the interaction terms. Table 4.8 illustrates the results, with Panel A presenting those for the yearly absolute changes and Panel B those for the quarterly standard deviations. In the cases in which the respective policy measure is part of the initial set of control variables, it is excluded from the controls.

${ }^{24}$ We ensure that we only include firm-years for which the necessary items are actually reported quarterly, which does not hold for all firm-years or all items in Compustat. 


\begin{tabular}{|c|c|c|c|c|c|c|c|c|}
\hline Panel A: Yearly absolute change & $\begin{array}{c}(1) \\
\mid \text { Change in } \\
\text { TotInv/Assets | }\end{array}$ & $\begin{array}{c}(2) \\
\mid \text { Change in } \\
\text { NetInv/Assets }\end{array}$ & $\begin{array}{c}(3) \\
\mid \text { Change in } \\
\text { CapEx/Assets | }\end{array}$ & $\begin{array}{c}(4) \\
\mid \text { Change in } \\
\text { R\&D/Assets | }\end{array}$ & $\begin{array}{c}(5) \\
\mid \text { Change in } \\
\text { AcqExp/Assets | }\end{array}$ & $\begin{array}{c}(6) \\
\mid \text { Change in } \\
\text { PPE | }\end{array}$ & $\begin{array}{c}(7) \\
\mid \text { Change in } \\
\text { Cash/Assets | }\end{array}$ & $\begin{array}{c}(8) \\
\text { | Change in } \\
\text { Market Leverage | }\end{array}$ \\
\hline Post $\times$ Treated & $\begin{array}{c}-1.0135^{* *} \\
(0.0110)\end{array}$ & $\begin{array}{c}-0.9979 * * \\
(0.0124)\end{array}$ & $\begin{array}{c}0.0113 \\
(0.9240)\end{array}$ & $\begin{array}{c}0.1007 \\
(0.1301)\end{array}$ & $\begin{array}{c}-1.2430^{* * *} \\
(0.0024)\end{array}$ & $\begin{array}{c}-2.6839^{* * *} \\
(0.0045)\end{array}$ & $\begin{array}{c}-0.4413^{*} \\
(0.0869)\end{array}$ & $\begin{array}{c}-0.5924^{*} \\
(0.0518)\end{array}$ \\
\hline $\begin{array}{l}\text { CEO Controls } \\
\text { Firm Controls } \\
\text { Firm Fixed Effects } \\
\text { Year Fixed Effects } \\
\text { Sample Size } \\
\text { Adj. R-Squared }\end{array}$ & $\begin{array}{l}\text { Yes } \\
\text { Yes } \\
\text { Yes } \\
\text { Yes } \\
14,022 \\
0.0772 \\
\end{array}$ & $\begin{array}{l}\text { Yes } \\
\text { Yes } \\
\text { Yes } \\
\text { Yes } \\
14,022 \\
0.0749 \\
\end{array}$ & $\begin{array}{l}\text { Yes } \\
\text { Yes } \\
\text { Yes } \\
\text { Yes } \\
14,022 \\
0.0585\end{array}$ & $\begin{array}{c}\text { Yes } \\
\text { Yes } \\
\text { Yes } \\
\text { Yes } \\
14,022 \\
0.0443 \\
\end{array}$ & $\begin{array}{c}\text { Yes } \\
\text { Yes } \\
\text { Yes } \\
\text { Yes } \\
14,022 \\
0.0924\end{array}$ & $\begin{array}{c}\text { Yes } \\
\text { Yes } \\
\text { Yes } \\
\text { Yes } \\
13,936 \\
0.0886 \\
\end{array}$ & $\begin{array}{c}\text { Yes } \\
\text { Yes } \\
\text { Yes } \\
\text { Yes } \\
14,022 \\
0.0063\end{array}$ & $\begin{array}{l}\text { Yes } \\
\text { Yes } \\
\text { Yes } \\
\text { Yes } \\
14,021 \\
0.0824 \\
\end{array}$ \\
\hline Panel B: Quarterly standard devi & $\begin{array}{l}\text { tion } \\
\qquad \begin{array}{l}\text { (1) } \\
\text { SD } \\
\text { TotInv/Assets }\end{array}\end{array}$ & $\begin{array}{c}(2) \\
\text { SD } \\
\text { NetInv/Assets }\end{array}$ & $\begin{array}{c}(3) \\
\text { SD } \\
\text { CapEx/Assets }\end{array}$ & $\begin{array}{c}(4) \\
\text { SD } \\
\text { R\&D/Assets }\end{array}$ & $\begin{array}{c}(5) \\
\text { SD } \\
\text { AcqExp/Assets }\end{array}$ & $\begin{array}{l}(6) \\
\text { SD } \\
\text { PPE }\end{array}$ & $\begin{array}{c}(7) \\
\text { SD } \\
\text { Cash/Assets }\end{array}$ & $\begin{array}{c}(8) \\
\text { SD } \\
\text { Market Leverage }\end{array}$ \\
\hline Post $\times$ Treated & $\begin{array}{c}-0.8266^{* *} \\
(0.0144)\end{array}$ & $\begin{array}{c}-0.8462^{* *} \\
(0.0131)\end{array}$ & $\begin{array}{l}-0.0243 \\
(0.7620)\end{array}$ & $\begin{array}{c}0.0672 \\
(0.2600)\end{array}$ & $\begin{array}{c}-0.7826^{* * *} \\
(0.0055)\end{array}$ & $\begin{array}{c}-15940.6297 \\
(0.4036)\end{array}$ & $\begin{array}{c}-0.6149 * * \\
(0.0218)\end{array}$ & $\begin{array}{c}-0.6384^{* *} \\
(0.0231)\end{array}$ \\
\hline $\begin{array}{l}\text { CEO Controls } \\
\text { Firm Controls } \\
\text { Firm Fixed Effects } \\
\text { Year Fixed Effects } \\
\text { Sample Size } \\
\text { Adj. R-Squared }\end{array}$ & $\begin{array}{l}\text { Yes } \\
\text { Yes } \\
\text { Yes } \\
\text { Yes } \\
11,200 \\
0.0749\end{array}$ & $\begin{array}{c}\text { Yes } \\
\text { Yes } \\
\text { Yes } \\
\text { Yes } \\
11,200 \\
0.0714\end{array}$ & $\begin{array}{c}\text { Yes } \\
\text { Yes } \\
\text { Yes } \\
\text { Yes } \\
13,983 \\
0.0488\end{array}$ & $\begin{array}{c}\text { Yes } \\
\text { Yes } \\
\text { Yes } \\
\text { Yes } \\
11,296 \\
0.0326\end{array}$ & $\begin{array}{c}\text { Yes } \\
\text { Yes } \\
\text { Yes } \\
\text { Yes } \\
13,902 \\
0.0692\end{array}$ & $\begin{array}{c}\text { Yes } \\
\text { Yes } \\
\text { Yes } \\
\text { Yes } \\
9,461 \\
0.0100\end{array}$ & $\begin{array}{c}\text { Yes } \\
\text { Yes } \\
\text { Yes } \\
\text { Yes } \\
14,007 \\
0.0084\end{array}$ & $\begin{array}{c}\text { Yes } \\
\text { Yes } \\
\text { Yes } \\
\text { Yes } \\
13,889 \\
0.1207\end{array}$ \\
\hline
\end{tabular}

This table presents the coefficient estimates from regressions of several measures for changes in risk-related firm policies on the DID interaction term and the full set of control variables. The dependent variables in Panel A are calculated as the absolute value of the difference in the policy's value between period $t$ and $t-1$, while the ones in Panel B represent the annualized standard deviation of quarterly values of the respective policy variable. Each regression is performed on the matched sample. Post is a dummy variable equal to one if the fiscal year is 2002 or later and zero otherwise. Treated is a dummy variable equal to one if a firm does not comply with the board independence requirement in fiscal year 2001 and zero otherwise. Definitions for the remaining variables can be found in Table C.1 in Appendix C. All models include firm and year fixed effects, as well as a constant term. The $p$-values are based on standard errors clustered at the firm-level and are reported in parentheses, with $*, * *$, and $* * *$ indicating significance levels of $10 \%, 5 \%$, and $1 \%$, respectively. 
Columns (1) and (2) of Panel A present the results for the treatment effect on yearly absolute changes of the two aggregated investment measures: total and net investment. The highly statistically significant negative coefficient estimates show that the treated firms' overall investment policy became more stable after the introduction of the listing requirements. The effect is economically substantial as well. Considering (unreported) mean total assets of $\$ 4,063.84$ million and a mean absolute change in TotInv/Assets of $6.27 \%$ per year of the treated firms in the pre-treatment era, the coefficient estimate of -1.01 in Column (1) of Panel A implies that - all else being equal — their yearly absolute change decreased by about $((1.01 / 6.27) \times 100=) 16.11 \%$ or by $(1.01 / 100 \times 4,063.84=) \$ 41.04$ million.

The results for the single investment measures in Columns (3) to (5) show that decreasing fluctuations in acquisition expenses appear to be the main driver behind the stabilization of the treated firms' investment policies. Among the three models, the negative coefficient estimate in Column (5) is highly statistically significant, while those for capital expenditures in Column (3) and R\&D expenditures in Column (4) do not show significance on any conventional level. Again, the effect for acquisition expenses appears to be economically meaningful, since the mean absolute change in AcqExp/Assets decreases — all else being equal-by $28.12 \%$ or $\$ 50.39$ million. $^{25}$

Furthermore, PPE, cash holdings, and market leverage exhibit lower fluctuations after the treatment, as suggested by the highly significant coefficient estimates in Columns (6) through (8). Hence, they represent three additional channels that contribute to the decrease in VOV.

Panel B presents the results for our second change proxy, the quarterly standard deviation, which focuses on within-year changes in the policies. The results largely confirm those from Panel A. As above, we find that fluctuations in total investment, net investment, acquisition expenses, cash holdings and market leverage decrease. Only PPE in Column (6) is not significant.

Collectively, the evidence in this section shows that several risk-related firm policies became more stable after the introduction of the independence requirement. This is in line with our conjecture that the decrease in VOV that we find throughout our analyses is due largely to the independent directors effecting fewer changes and deviations in policy choices, which should make both the policies and the firm easier to evaluate for shareholders and reduce the level of ambiguity.

\footnotetext{
${ }^{25}$ Calculations are performed just as above, considering an unreported mean absolute change in AcqExp/Assets of $4.41 \%$ per year of the treated firms in the pre-treatment era.
} 


\subsubsection{Are certain firms impacted differently?}

So far, we have interpreted the VOV as an expression of frequent changes in firm policies that are hard for shareholders to understand and evaluate. Thus, we would generally expect a reduction in VOV to be a positive development for firms. A possible alternative interpretation is that frequent policy changes are attempts to adapt to a changing dynamic environment (Hogarth and Makridakis, 1981; Chakravarthy, 1982). If that is the case, a high VOV would actually be a sign of positive changes in firm policy. Since our analyses show that board independence reduces the $\mathrm{VOV}$, it is conceivable that independent directors stifle necessary strategic change or frequent adjustments to firm policies. Consistent with that argument, previous research has shown that independent directors are not always better monitors, especially when firm-specific knowledge is required (Wintoki, 2007). Such knowledge is arguably required in highly dynamic environments (Lecuona and Reitzig, 2014); thus, for some firms, reduced VOV may be negative consequence of the listing rule changes.

To test whether this is the case, we first have to identify dynamic, perpetually changing environments that may require firms to adapt frequently. We focus on the industries in which the firms operate and use two measures to classify these, namely industry dynamism and volatility. For the first measure, we draw on organizational and management literature, which defines a dynamic environment as one with "a highly unpredictable and unstable rate of change and high levels of uncertainty about the state of the context, the means-ends relationships, and/or the outcomes of actions" (Mitchell et al., 2011, p. 687). ${ }^{26}$ The most common approach to measuring industry dynamism is to regress industry-wide values of shipments or sales, measured over several years, on a trend variable and then employ the standard error of the regression coefficient, normalized by average industry shipments/sales, as the respective measure (e.g., Dess and Beard, 1984; Simerly and Li, 2000; Wang et al., 2012). We follow this approach using firm-level sales data for all U.S. firms in Compustat for the sample period of our study (1996-2015). More specifically, we assign all firms to Fama and French 49 industries based on their SIC codes and estimate the following regression for each industry:

$$
\text { Total Sales }_{j, t}=\alpha+\beta_{j} \text { Year }_{t}+\epsilon_{j, t}
$$

\footnotetext{
${ }^{26}$ This literature uses a variety of dimensions to characterize a firm's external environment. Shepherd and Rudd (2014) provide an overview of different dimensions identified. The most relevant dimension for our study is dynamism.
} 
where Total Sales $j, t$ is the total sales of industry $j$ in year $t$, Year $_{t}$ is a trend variable, and $\epsilon_{j, t}$ is the regression residual for industry $j$ in year $t$. To obtain one value of dynamism for each industry, we calculate the standard deviation of the estimated regression residuals over the whole sample period and divide it by the average sales of the respective industry. This measure reflects the changes in (unexpected) total industry sales while taking into account a possible trend over time, such as industry growth from inflation. We then define the dummy variable Dynamism High (Dynamism Low) which takes the value of one if the respective industry exhibits an industry dynamism above (below or equal to) the median and zero otherwise.

For our second measure, we follow Masulis et al. (2020) and use stock market data to calculate industry volatility. We first calculate the annual standard deviation of daily stock returns for each firm covered by CRSP. From those, we compute the yearly mean standard deviations for each Fama and French 49 industry and average these yearly means over the full sample period of our study (1996-2015) to obtain our measure of industry volatility. As with the dynamism measure, we then define the dummy variable Industry Vol High (Industry Vol Low) which takes the value of one if the respective industry exhibits an industry volatility above (below or equal to) the median and zero otherwise.

We then apply these industry classifications to the sample of this study and check whether firms in dynamic or volatile industries are affected differently than their respective counterparts. In doing so, we first check if our baseline effect on the VOV occurs for firms in both industries. To analyze whether the VOV reduction represents a positive or a negative development for the firms, we next analyze whether the introduction of the independence requirement affects the valuation of firms in both groups differently. We use two common measures for firm valuation, that is Tobin's $Q$ and Total $Q$, the latter of which better accounts for the firms' intangible capital (Peters and Taylor, 2017). Empirically, we apply the approach from Equation (4.2) and split the treatment effect for firms in industries with high/low dynamism or high/low volatility, respectively. ${ }^{27}$ As dependent variables, we use our Scaled VOV and the two measures for firm valuation. Table 4.9 illustrates the results.

\footnotetext{
${ }^{27}$ Note that we classify the industries "outside" of the sample, that is by considering the whole Compustat or CRSP universe with relevant data and irrespective of the treatment. As a consequence, the number of treated firms differs between the high and low groups. In particular, 181 (64) of the 245 treated firms fall into industries with high (low) dynamism and 175 (70) firms operate in industries with high (low) volatility.
} 
Table 4.9: Effect in stable and dynamic industries

\begin{tabular}{|c|c|c|c|c|}
\hline \multirow[t]{3}{*}{ Panel A: VOV } & \multirow{2}{*}{\multicolumn{2}{|c|}{ Industry Dynamism }} & \multirow{2}{*}{\multicolumn{2}{|c|}{ Industry Volatility }} \\
\hline & & & & \\
\hline & $\begin{array}{c}(1) \\
\text { Scaled VOV }\end{array}$ & $\begin{array}{c}(2) \\
\text { Scaled VOV }\end{array}$ & $\begin{array}{c}(3) \\
\text { Scaled VOV }\end{array}$ & $\begin{array}{c}(4) \\
\text { Scaled VOV }\end{array}$ \\
\hline Post $\times$ Treated $\times$ Dynamism High & $\begin{array}{c}-1.2269^{* *} \\
(0.0265)\end{array}$ & $\begin{array}{c}-1.2632^{* *} \\
(0.0250)\end{array}$ & & \\
\hline Post $\times$ Treated $\times$ Dynamism Low & $\begin{array}{c}-2.2329^{* *} \\
(0.0308)\end{array}$ & $\begin{array}{c}-2.4264^{* *} \\
(0.0158)\end{array}$ & & \\
\hline Post $\times$ Treated $\times$ Industry Vol High & & & $\begin{array}{c}-1.6051^{* *} \\
(0.0263)\end{array}$ & $\begin{array}{c}-1.8220^{* *} \\
(0.0119)\end{array}$ \\
\hline Post $\times$ Treated $\times$ Industry Vol Low & & & $\begin{array}{c}-1.4203^{* *} \\
(0.0291)\end{array}$ & $\begin{array}{c}-1.3755^{* *} \\
(0.0361)\end{array}$ \\
\hline CEO Controls & No & Yes & No & Yes \\
\hline Firm Controls & Yes & Yes & Yes & Yes \\
\hline Firm Fixed Effects & Yes & Yes & Yes & Yes \\
\hline Year Fixed Effects & Yes & Yes & Yes & Yes \\
\hline Sample Size & 14,122 & 14,025 & 14,122 & 14,025 \\
\hline Adj. R-Squared & 0.1447 & 0.1462 & 0.1446 & 0.1461 \\
\hline \multicolumn{5}{|l|}{ Panel B: Tobin's $Q$} \\
\hline & \multicolumn{2}{|c|}{ Industry Dynamism } & \multicolumn{2}{|c|}{ Industry Volatility } \\
\hline & $\begin{array}{c}(1) \\
\text { Ln(Tobin's Q) }\end{array}$ & $\begin{array}{c}(2) \\
\text { Ln(Tobin's Q) }\end{array}$ & $\begin{array}{c}(3) \\
\operatorname{Ln}(\text { Tobin's Q) }\end{array}$ & $\begin{array}{c}(4) \\
\operatorname{Ln}(\text { Tobin's Q) }\end{array}$ \\
\hline Post $\times$ Treated $\times$ Dynamism High & $\begin{array}{c}-0.0559^{*} \\
(0.0680)\end{array}$ & $\begin{array}{c}-0.0568^{*} \\
(0.0606)\end{array}$ & & \\
\hline Post $\times$ Treated $\times$ Dynamism Low & $\begin{array}{c}0.1093^{* * *} \\
(0.0019)\end{array}$ & $\begin{array}{c}0.1124^{* * *} \\
(0.0015)\end{array}$ & & \\
\hline Post $\times$ Treated $\times$ Industry Vol High & & & $\begin{array}{c}-0.0763^{* *} \\
(0.0344)\end{array}$ & $\begin{array}{c}-0.0809^{* *} \\
(0.0227)\end{array}$ \\
\hline Post $\times$ Treated $\times$ Industry Vol Low & & & $\begin{array}{l}0.0583^{*} \\
(0.0666)\end{array}$ & $\begin{array}{c}0.0629^{* *} \\
(0.0469)\end{array}$ \\
\hline CEO Controls & No & Yes & No & Yes \\
\hline Firm Controls & Yes & Yes & Yes & Yes \\
\hline Firm Fixed Effects & Yes & Yes & Yes & Yes \\
\hline Year Fixed Effects & Yes & Yes & Yes & Yes \\
\hline Sample Size & 14,122 & 14,025 & 14,122 & 14,025 \\
\hline Adj. R-Squared & 0.2965 & 0.2986 & 0.2960 & 0.2982 \\
\hline \multicolumn{5}{|l|}{ Panel C: Total $Q$} \\
\hline & \multicolumn{2}{|c|}{ Industry Dynamism } & \multicolumn{2}{|c|}{ Industry Volatility } \\
\hline & $\begin{array}{c}(1) \\
\operatorname{Ln}(\text { Total Q) }\end{array}$ & $\begin{array}{c}(2) \\
\operatorname{Ln}(\text { Total Q })\end{array}$ & $\begin{array}{c}(3) \\
\operatorname{Ln}(\text { Total Q) }\end{array}$ & $\begin{array}{c}(4) \\
\operatorname{Ln}(\text { Total Q) }\end{array}$ \\
\hline Post $\times$ Treated $\times$ Dynamism High & $\begin{array}{c}-0.1527^{* *} \\
(0.0202)\end{array}$ & $\begin{array}{c}-0.1552^{* *} \\
(0.0152)\end{array}$ & & \\
\hline Post $\times$ Treated $\times$ Dynamism Low & $\begin{array}{l}0.1603^{*} \\
(0.0698)\end{array}$ & $\begin{array}{l}0.1662^{*} \\
(0.0634)\end{array}$ & & \\
\hline Post $\times$ Treated $\times$ Industry Vol High & & & $\begin{array}{c}-0.2388^{* * *} \\
(0.0025)\end{array}$ & $\begin{array}{c}-0.2519^{* * *} \\
(0.0009)\end{array}$ \\
\hline Post $\times$ Treated $\times$ Industry Vol Low & & & $\begin{array}{c}0.1051 \\
(0.1260)\end{array}$ & $\begin{array}{l}0.1157^{*} \\
(0.0916)\end{array}$ \\
\hline CEO Controls & No & Yes & No & Yes \\
\hline Firm Controls & Yes & Yes & Yes & Yes \\
\hline Firm Fixed Effects & Yes & Yes & Yes & Yes \\
\hline Year Fixed Effects & Yes & Yes & Yes & Yes \\
\hline Sample Size & 13,616 & 13,523 & 13,616 & 13,523 \\
\hline
\end{tabular}


Table 4.9 Continued

\begin{tabular}{lllll}
\hline Adj. R-Squared & 0.2592 & 0.2625 & 0.2603 & 0.2638 \\
\hline
\end{tabular}

This table presents the coefficient estimates from regressions on the matched sample in which we separate the treatment effect for firms operating in industries with high and low dynamism or high and low volatility, respectively. The dependent variables are Scaled VOV in Panel A, Ln(Tobin's Q) in Panel B, and Ln(Total Q) in Panel C. Post is a dummy variable equal to one if the fiscal year is 2002 or later and zero otherwise. Treated is a dummy variable equal to one if a firm does not comply with the board independence requirement in fiscal year 2001 and zero otherwise. Definitions for the remaining variables can be found in Table C.1 in Appendix C. All models include firm and year fixed effects, as well as a constant term. The $p$-values are based on standard errors clustered at the firm-level and are reported in parentheses, with *,**, and *** indicating significance levels of $10 \%, 5 \%$, and $1 \%$, respectively.

Panel A presents the results for the VOV, which show that the VOV is indeed reduced in both groups of firms after the treatment, whereas the reduction appears to be somewhat stronger economically for firms in stable industries. The results for Tobin's $Q$ in Panel B and Total $Q$ in Panel $\mathrm{C}$ show that firms in dynamic or volatile industries experience a decline in firm valuation after the introduction of the independence requirement, which is in line with the notion that higher board independence impedes necessary adjustments to a changing environment, actually harming the value of the firm. This also suggests that firms in dynamic industries benefit from changing policies even though the changes themselves may be difficult to understand. This poses a challenge for these firms, especially if monitoring requires industry-specific knowledge, which outside directors often do not have. Conversely, firms in rather stable industries exhibit an increase in valuation in the post-treatment era, providing support for our initial conjecture that the reduction in VOV presents a positive development for those firms. Notably, all of these results hold for both of our industry classification schemes.

In addition to splitting the industries at the median, Masulis et al. (2020) also conduct a test with a split at the 75 th percentile of industry volatility. We follow that approach, which leads to a more extreme classification of volatile industries (i.e., the top 25\%) such that a considerably smaller number of treated firms fall into the category of highly volatile industries (91), while a greater number are classified in industries with low volatility (154). This (unreported) test reveals three things: first, the negative effect on the VOV is almost unchanged, that is it occurs for firms in both industry classes with a very similar magnitude; second, the increase in Tobin's Q for firms in low-volatility industries is also constant and even stronger in statistical significance, while Total Q is not statistically significant at the $10 \%$ level; and third, the reduction in both Q measures for firms in highly volatile industries now appears to be much stronger, statistically and economically. ${ }^{28}$ This suggests that it is mainly the firms operating in extremely volatile

\footnotetext{
${ }^{28}$ For example, the equivalent coefficient estimate for firms in highly volatile industries for the model presented in Column (4) of Panel B is then -0.1412 ( $p$-value of 0.0014 ), which is about $75 \%$ lower than that in Table 4.9 .
} 
environments that drive the reduction in firm valuation and that this type of firm is negatively impacted by the change in board structure. The majority of firms, however, seem to benefit from increased board independence.

Overall, the results in this section lead us to conclude that the one-size-fits all approach of the listing rules may not be beneficial for all firms, providing further support to previous studies, such as Wintoki (2007). Nevertheless, the results for firms in stable industries underscore our interpretation that a reduction in the VOV is very positive for shareholders of such firms.

\subsubsection{Additional robustness checks}

In addition to the robustness checks presented throughout the study (e.g., to address concerns regarding the sample period in Section 4.4.3), we conduct an array of tests that further establish the robustness of our principal results.

\section{Alternative matching procedures}

First, we check whether our results hold for alternative specifications in our propensity score model. Our model contains several variables that are likely to influence treatment assignment and the VOV. Which variables to include, however, is ultimately a discretionary choice. Thus, we repeat our analyses while using several different subsets of the matching variables. Alternative specifications range from including only the natural log of total assets to less parsimonious models. In all the specifications, we still only match firms from the same industry and apply our standard caliper of 0.15 . The (unreported) tests show that our results are robust to different specifications of the propensity score model.

Second, to further address concerns that the remaining observable differences between treated and control firms may drive our results, we adjust our PSM in that we directly match on the characteristics that Table 4.2 reveals to be still different between the two groups of firms. Specifically, we exclude the respective variable from the propensity score estimation, yet only match treated firms that show values above (below) the sample median of this variable in 2001 with control firms with values above (below). We do this for each of the variables separately and re-estimate our analyses. In each case, we obtain very similar results as in our main analyses.

Third, propensity score matching is not without criticism, as it can lead to extreme model dependence and loss of estimation efficiency. An approach that can limit these shortcomings is coarsened exact matching (CEM), which does not attempt to achieve complete randomization 
but rather approximates fully blocked experiments (Iacus et al., 2011, 2012). We follow Balsmeier et al. (2017), who use the same setting as we do, and conduct a very similar CEM. Specifically, we match on the joint distribution of $\operatorname{Ln}$ (Total Assets), R\&D/Assets, MTB, Board Size, and Fama and French 12 industries. We use the average values for the years 2000 and 2001 to differentiate firms along three categories for each of the variables, except for the industry dummies. When we re-run our analyses on this newly matched sample, our results remain qualitatively unchanged, giving us confidence that our results are not driven by the specification of the matching procedure.

\section{Parallel trends assumption}

Fourth, our identification strategy via the DID approach requires treated and control firms to follow parallel trends with respect to the VOV prior to the treatment. To check if this holds for our sample firms, we perform two tests. First, we restrict our sample to the pre-treatment period (1996-2001) and define placebo treatments, once in 1998 and once in 1999. The Post 1997 (1998) dummies, which are again interacted with the Treated dummy, indicate the years 1998 (1999) or later. Such a placebo treatment should not reveal a change in the difference between the two groups of firms prior to the treatment if the parallel trend assumption holds. Thus, we expect the coefficient estimates to be statistically insignificant. Second, we replace the single DID interaction with several interactions between Treated and indicators for the individual years starting in 1997 for the full sample. To keep the model parsimonious, we combine the years 2006 through 2015 into one dummy named Post 2005. ${ }^{29}$ These interactions then illustrate the treatment effects by year compared to 1996, which, having been omitted, serves as the benchmark year. Significant coefficient estimates on the interaction terms during the pre-treatment era would show a differing trend for one of the groups even before the actual treatment sets in. Thus, we expect the coefficients on the interaction terms for the years 1997 to 2001 to be insignificant.

Table 4.10 presents the results for the two tests. As expected, the placebo tests in Models (1) through (4) show no significant effect during the pre-treatment period, neither for an onset of the treatment in 1998 nor if the treatment is assumed to occur in 1999. Moreover, in Models (5) and (6) we find no significant treatment effects during the years 1997 to 2001. Thus, these findings support the parallel trends assumption, giving us further confidence that our results are not driven by differing trends in VOV between our treated and control firms prior to the treatment. In addition, Models (5) and (6) also reveal that the treatment effect commences in

\footnotetext{
${ }^{29}$ In an unreported test, we repeat this analysis while including interaction terms for every year of our sample, except 1996. The inferences of this test are the same as in the analysis presented in this section.
} 
Table 4.10: Tests of parallel trends assumption

\begin{tabular}{|c|c|c|c|c|c|c|}
\hline & \multicolumn{2}{|c|}{$\begin{array}{l}\text { Placebo treatment in } 1998 \\
\quad \text { (Sample: } 1996-2001)\end{array}$} & \multicolumn{2}{|c|}{$\begin{array}{l}\text { Placebo treatment in } 1999 \\
\quad \text { (Sample: } 1996-2001)\end{array}$} & \multicolumn{2}{|c|}{ Yearly treatment effects } \\
\hline & $\begin{array}{c}(1) \\
\text { Scaled VOV }\end{array}$ & $\begin{array}{c}(2) \\
\text { Scaled VOV }\end{array}$ & $\begin{array}{c}(3) \\
\text { Scaled VOV }\end{array}$ & $\begin{array}{c}(4) \\
\text { Scaled VOV }\end{array}$ & $\begin{array}{c}(5) \\
\text { Scaled VOV }\end{array}$ & $\begin{array}{c}(6) \\
\text { Scaled VOV }\end{array}$ \\
\hline Post $1997 \times$ Treated & $\begin{array}{l}-0.7122 \\
(0.3727)\end{array}$ & $\begin{array}{l}-0.8258 \\
(0.2937)\end{array}$ & & & & \\
\hline Post $1998 \times$ Treated & & & $\begin{array}{c}0.4422 \\
(0.5313)\end{array}$ & $\begin{array}{c}0.3706 \\
(0.5965)\end{array}$ & & \\
\hline $1997 \times$ Treated & & & & & $\begin{array}{c}0.0964 \\
(0.9404)\end{array}$ & $\begin{array}{c}0.1111 \\
(0.9319)\end{array}$ \\
\hline $1998 \times$ Treated & & & & & $\begin{array}{l}-1.9237 \\
(0.1623)\end{array}$ & $\begin{array}{l}-1.9693 \\
(0.1565)\end{array}$ \\
\hline $1999 \times$ Treated & & & & & $\begin{array}{l}-0.5401 \\
(0.6805)\end{array}$ & $\begin{array}{l}-0.4295 \\
(0.7443)\end{array}$ \\
\hline $2000 \times$ Treated & & & & & $\begin{array}{c}0.1820 \\
(0.8836)\end{array}$ & $\begin{array}{c}0.1549 \\
(0.9015)\end{array}$ \\
\hline $2001 \times$ Treated & & & & & $\begin{array}{l}-1.1042 \\
(0.3907)\end{array}$ & $\begin{array}{l}-1.1000 \\
(0.3928)\end{array}$ \\
\hline $2002 \times$ Treated & & & & & $\begin{array}{c}-2.9655^{* *} \\
(0.0249)\end{array}$ & $\begin{array}{c}-2.9320^{* *} \\
(0.0275)\end{array}$ \\
\hline $2003 \times$ Treated & & & & & $\begin{array}{l}-1.9086 \\
(0.1413)\end{array}$ & $\begin{array}{l}-1.9500 \\
(0.1361)\end{array}$ \\
\hline $2004 \times$ Treated & & & & & $\begin{array}{l}-2.2607^{*} \\
(0.0810)\end{array}$ & $\begin{array}{l}-2.3292^{*} \\
(0.0740)\end{array}$ \\
\hline $2005 \times$ Treated & & & & & $\begin{array}{c}-2.8782^{* *} \\
(0.0469)\end{array}$ & $\begin{array}{c}-3.5030^{* *} \\
(0.0123)\end{array}$ \\
\hline Post $2005 \times$ Treated & & & & & $\begin{array}{l}-1.8605^{*} \\
(0.0866)\end{array}$ & $\begin{array}{l}-1.8834^{*} \\
(0.0887)\end{array}$ \\
\hline CEO Controls & No & Yes & No & Yes & No & Yes \\
\hline Firm Controls & Yes & Yes & Yes & Yes & Yes & Yes \\
\hline Firm Fixed Effects & Yes & Yes & Yes & Yes & Yes & Yes \\
\hline Year Fixed Effects & Yes & Yes & Yes & Yes & Yes & Yes \\
\hline Sample Size & 4,454 & 4,417 & 4,454 & 4,417 & 14,122 & 14,025 \\
\hline Adj. R-Squared & 0.0749 & 0.0735 & 0.0748 & 0.0734 & 0.1446 & 0.1462 \\
\hline
\end{tabular}

This table presents the coefficient estimates from tests of the parallel trends assumption. The placebo tests in Models (1) through (4) are performed on the reduced sample from 1996 to 2001, while we use the full matched sample for the tests that include the yearly treatment effects. The dependent variable in all the models is Scaled VOV. Post $199^{7}$ is a dummy variable equal to one if the fiscal year is 1998 or later and zero otherwise. Post 1998 and Post 2005 are defined accordingly. The single year indicators (e.g., 1997) are equal to one for the respective fiscal year. Treated is a dummy variable equal to one if a firm does not comply with the board independence requirement in fiscal year 2001 and zero otherwise. Definitions for the variables can be found in Table C.1 in Appendix C. All models include firm and year fixed effects, as well as a constant term. The $p$-values are based on standard errors clustered at the firm-level and are reported in parentheses, with *, **, and *** indicating significance levels of $10 \%, 5 \%$, and $1 \%$, respectively. 
2002 and shows up as significant in every subsequent year, except for 2003, which is still within the transition phase.

Omitted variable bias

Fifth, an often-raised concern in empirical research is that of an omitted variable bias that drives the results. Since we include firm fixed effects in all of our analyses, we believe that this is a minor concern. Nonetheless, we add a whole host of additional control variables to our baseline regressions that could potentially influence the VOV. The role of board size as a governance mechanism is well documented (e.g., Yermack, 1996; Cheng, 2008), as is the importance of external governance arrangements (Cremers and Nair, 2005), for which we proxy with the E Index (Bebchuk et al., 2009). Additionally, we include the compensation delta and vega, which we obtain from Coles et al. (2006), and CEO age (Serfling, 2014). We also control for asset tangibility (PPE/Assets), for market - as opposed to book-leverage, firm age, and market-wide volatility by including the yearly average of the Volatility Index (VIX). The results are presented in Table 4.11 and are fully consistent with our baseline results. Moreover, our study's results remain fundamentally unchanged when we exemplarily re-run all of our analyses with the full set of controls, just as in the model in Column (10). 


\begin{tabular}{|c|c|c|c|c|c|c|c|c|c|c|}
\hline & $\begin{array}{c}(1) \\
\text { Scaled VOV }\end{array}$ & $\begin{array}{c}(2) \\
\text { Scaled VOV }\end{array}$ & $\begin{array}{c}(3) \\
\text { Scaled VOV }\end{array}$ & $\begin{array}{c}(4) \\
\text { Scaled VOV }\end{array}$ & $\begin{array}{c}(5) \\
\text { Scaled VOV }\end{array}$ & $\begin{array}{c}(6) \\
\text { Scaled VOV }\end{array}$ & $\begin{array}{c}(7) \\
\text { Scaled VOV }\end{array}$ & $\begin{array}{c}(8) \\
\text { Scaled VOV }\end{array}$ & $\begin{array}{c}(9) \\
\text { Scaled VOV }\end{array}$ & $\begin{array}{c}(10) \\
\text { Scaled VOV }\end{array}$ \\
\hline Post $\times$ Treated & $\begin{array}{c}-1.5931^{* * *} \\
(0.0022)\end{array}$ & $\begin{array}{c}-1.6248^{* * * *} \\
(0.0017)\end{array}$ & $\begin{array}{c}-1.6809^{* * * *} \\
(0.0020)\end{array}$ & $\begin{array}{c}-1.5241^{* * *} \\
(0.0038)\end{array}$ & $\begin{array}{c}-1.5631^{* * *} \\
(0.0027)\end{array}$ & $\begin{array}{c}-1.5350^{* * * *} \\
(0.0036)\end{array}$ & $\begin{array}{c}-1.5712^{* * * *} \\
(0.0025)\end{array}$ & $\begin{array}{c}-1.6079^{* * * *} \\
(0.0020)\end{array}$ & $\begin{array}{c}-1.6204^{* * * *} \\
(0.0017)\end{array}$ & $\begin{array}{c}-1.5102^{* * *} \\
(0.0061)\end{array}$ \\
\hline Ln(Board Size) & $\begin{array}{l}-0.4849 \\
(0.5179)\end{array}$ & & & & & & & & & $\begin{array}{l}-0.9522 \\
(0.2247)\end{array}$ \\
\hline E Index & & $\begin{array}{c}0.2104 \\
(0.1463)\end{array}$ & & & & & & & & $\begin{array}{c}0.1523 \\
(0.3205)\end{array}$ \\
\hline Delta & & & $\begin{array}{l}-0.0000 \\
(0.4037)\end{array}$ & & & & & & & $\begin{array}{l}-0.0000 \\
(0.3272)\end{array}$ \\
\hline Vega & & & & $\begin{array}{l}0.0004 \\
(0.2742)\end{array}$ & & & & & & $\begin{array}{c}0.0008^{* *} \\
(0.0358)\end{array}$ \\
\hline CEO Age & & & & & $\begin{array}{c}0.0137 \\
(0.5256)\end{array}$ & & & & & $\begin{array}{c}0.0084 \\
(0.7195)\end{array}$ \\
\hline PPE/Assets & & & & & & $\begin{array}{l}-0.0052 \\
(0.5610)\end{array}$ & & & & $\begin{array}{l}-0.0098 \\
(0.3343)\end{array}$ \\
\hline Market Leverage & & & & & & & $\begin{array}{c}0.1051^{* * *} \\
(0.0000)\end{array}$ & & & $\begin{array}{c}0.0978^{* * *} \\
(0.0000)\end{array}$ \\
\hline Firm Age & & & & & & & & $\begin{array}{l}-1.0263 \\
(0.5720)\end{array}$ & & $\begin{array}{l}-1.6217 \\
(0.4213)\end{array}$ \\
\hline Average VIX & & & & & & & & & $\begin{array}{c}0.5773^{* * *} \\
(0.0000) \\
\end{array}$ & $\begin{array}{c}0.5443^{* * *} \\
(0.0000) \\
\end{array}$ \\
\hline CEO Controls & Yes & Yes & Yes & Yes & Yes & Yes & Yes & Yes & Yes & Yes \\
\hline Firm Controls & Yes & Yes & Yes & Yes & Yes & Yes & Yes & Yes & Yes & Yes \\
\hline Firm Fixed Effects & Yes & Yes & Yes & Yes & Yes & Yes & Yes & Yes & Yes & Yes \\
\hline Year Fixed Effects & Yes & Yes & Yes & Yes & Yes & Yes & Yes & Yes & Yes & Yes \\
\hline Sample Size & 14,025 & 14,025 & 12,551 & 12,833 & 14,014 & 13,947 & 14,025 & 14,025 & 14,025 & 12,469 \\
\hline Adj. R-Squared & 0.1461 & 0.1462 & 0.1525 & 0.1522 & 0.1466 & 0.1457 & 0.1534 & 0.1461 & 0.1548 & 0.1674 \\
\hline
\end{tabular}

This table presents the coefficient estimates from regressions in which we add additional control variables to our baseline model. In all models the dependent variable is Scaled VOV, which is regressed on the DID interaction term and different sets of control variables. Each regression is performed on the matched sample. Post is a dummy variable equal to one if the fiscal year is 2002 or later and zero otherwise. Treated is a dummy variable equal to one if a firm does not comply with the board independence requirement in fiscal year 2001 and zero otherwise. Definitions for the remaining variables can be found in Table C.1 in Appendix C. All models include firm and year fixed effects, as well as a constant term. The $p$-values are based on standard errors clustered at the firm-level and are reported in parentheses, with $*$, $* *$, and $* * *$ indicating significance levels of $10 \%, 5 \%$, and $1 \%$, respectively. 


\section{Confounding CEO turnovers}

Sixth, we follow Humphery-Jenner et al. (2019) and address the concern that changes in investment decisions, which may eventually affect the VOV, could be caused by the replacement of the firms' (powerful) CEOs around the time of the introduction of SOX and the listing rule changes. Consequently, we re-estimate our baseline model, yet exclude the 53 treated firms that replaced their CEO from 2001 to 2003. The (unreported) results confirm our main findings, while showing an even greater economic magnitude of the effect.

\section{Firms exempted from the listing requirements}

Seventh, in line with Guo and Masulis (2015), we also check the robustness of our results by excluding "closely controlled firms", which are exempt from the new listing requirements. Since we have no detailed ownership data, we follow Guo and Masulis (2015) and identify them as treated firms that still did not have a majority independent board in 2005, the final year for compliance with the new regulation. We then exclude them from our sample and re-estimate our initial model. The (unreported) results confirm our baseline results with even somewhat larger coefficient estimates, implying that the economic magnitude of the effect is higher. Notably, including these firms throughout our main analyses should generally work against us finding statistically and economically significant effects.

\section{Idiosyncratic VOV}

Lastly, we check whether we obtain similar results when we use idiosyncratic VOV as the dependent variable of interest. So far, we have calculated the VOV based on overall stock return volatility, meaning that we are potentially picking up market-wide effects beyond managerial or board control. For this reason, we also calculate our VOV measures based on idiosyncratic volatility, which managers may more likely be able to influence. To obtain the idiosyncratic volatility, we use residuals from the Fama-French-3-Factor and the market model. ${ }^{30}$ Our results are virtually unchanged.

\subsection{Conclusion}

We examine whether board structure impacts the ambiguity faced by shareholders, measured as the VOV. Using a quasi-exogenous shock to board independence caused by the NYSE and

\footnotetext{
${ }^{30}$ We collect data, including the risk-free rate, for the model from Kenneth French's data library (available at http://mba.tuck.dartmouth.edu/pages/faculty/ken.french/data_library.html).
} 
NASDAQ listing rule changes to establish causality, we find that greater independence can reduce the VOV by up to $10 \%$, a statistically and economically significant margin. Our main finding holds for a variety of tests, such as those addressing different time aspects (e.g., the financial crisis) and conditioning on firm and governance characteristics, including CEO-chair duality, co-option, or entrenchment.

As the prior literature suggests that ambiguity arises when shareholders cannot fully understand or evaluate policy decisions of the firm, we identify policy channels that independent directors can affect to lower the VOV. Firms that increased board independence following the listing rule changes exhibited lower overall and net investment fluctuations, which appear to be primarily driven by more stability in acquisition expenses. Their cash holdings and leverage levels also became more stable. Both results hold for measures across and within fiscal years. Furthermore, we show that PPE expenditures become more stable across years. Again, the results are both statistically significant and economically meaningful.

The reduction in ambiguity is similar in dynamic or volatile as well as stable industries. However, only in the latter do firms have higher market valuations in Tobin's Q after the change in board structure. In volatile industries, where more adjustments in firm policies may be necessary, market valuations fall. However, a majority of firms benefit from the reform.

This study contributes to the fast-growing ambiguity literature by showing that boards can reduce ambiguity, which is a novel finding and different from earlier studies on firm risk. Specifically, independent boards achieve the reduction by bringing about more stability in a firm's policy decisions, which makes them easier for shareholders to understand and evaluate. This finding implies that shareholders can use their influence on boards to establish more stability and thus reduce ambiguity. A second implication derives from the fact that firms in dynamic or volatile environments are negatively affected by the rules. For regulators, it means that they need to carefully consider negative side effects of broad governance reforms. For firms in those industries, it means that they need to look for ways to make their policy decisions easier to understand so that investors do not want to stifle their necessary adjustments. Conceivably, better communication strategies could help lessen the perceived ambiguity, which leads to the final implication: More research is needed to investigate which other firm or governance characteristics, such as director diversity or a board's power concentration, affect ambiguity, and if they do, whether they increase or decrease the ambiguity. 


\section{Appendix}

Figure C.1: Board independence over time
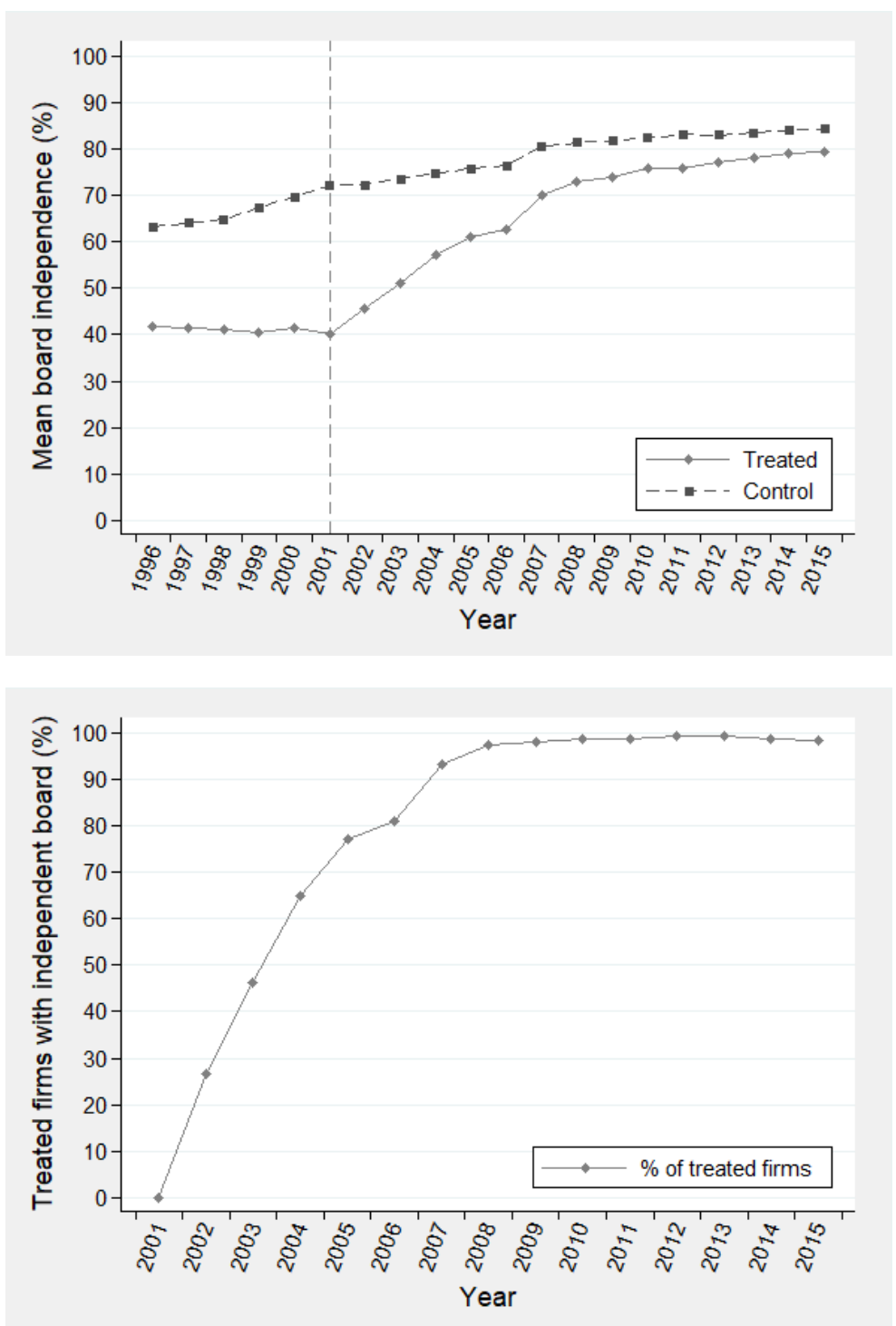

This figure illustrates the development of board independence among the firms in our sample over time. The top panel compares mean board independence of the treated and control firms for the years 1996 to 2015 . The bottom panel shows the fraction of treated firms that have a majority independent board for the years 2001 (the year in which we assign treated and control firms) to 2015. 
Table C.1: Variable definitions

\begin{tabular}{lll}
\hline Variable & Definition & Data Source \\
\hline VOV Measures & & Annualized standard deviation of monthly stock return volatilities \\
VOV $(\%)$ & CRSP \\
& $\begin{array}{l}\text { of the firm's fiscal year, with monthly stock return volatilities } \\
\text { calculated as the standard deviation of daily stock returns for } \\
\end{array}$ & \\
& every month in a given year. & \multirow{2}{*}{ VOV divided by the annualized mean of monthly stock return } \\
Scaled VOV (\%) & volatilities of the firm's fiscal year. & \\
\hline
\end{tabular}

\section{Board Independence}

Independence (\%) Number of independent directors divided by the total number of directors on the board. Following the definitions of the ISS database a director is determined to be independent if he or she is not an employee or former executive of the firm, does not stand in a significant transactional, professional, financial, or charitable relationship with the firm, and is not a family member of a current employee of the firm.

\begin{tabular}{|c|c|c|}
\hline \multicolumn{3}{|l|}{ Governance \& $\mathrm{CEO}$} \\
\hline Board Size & Number of directors on the board. & ISS Directors \\
\hline CEO Age & Age of the CEO in office. & ExесиСотр \\
\hline CEO Duality & $\begin{array}{l}\text { Dummy variable equal to one, if the CEO is also the chairperson } \\
\text { of the board; zero otherwise. }\end{array}$ & ISS Directors \\
\hline CEO is Founder & $\begin{array}{l}\text { Dummy variable equal to one, if the CEO is one of the founders } \\
\text { of the firm; zero otherwise. }\end{array}$ & $\begin{array}{l}\text { ExecuComp \& } \\
\text { hand-collected }\end{array}$ \\
\hline CEO Ownership (\%) & Fraction of the firm's shares owned by the CEO, options excluded. & ExecuСomp \\
\hline CEO Tenure & Years since the CEO assumed office. & ExecuСomp \\
\hline Co-Option (\%) & $\begin{array}{l}\text { Number of directors elected after the CEO assumed office divided } \\
\text { by the total number of directors on the board, as defined in Coles } \\
\text { et al. (2014). }\end{array}$ & $\begin{array}{l}\text { Naveen's web- } \\
\text { site }\end{array}$ \\
\hline Delta & $\begin{array}{l}\text { Change in the dollar value of the CEO's wealth for a one per- } \\
\text { centage point change in stock price, as defined in Coles et al. } \\
(2006) \text {. }\end{array}$ & $\begin{array}{l}\text { Naveen's web- } \\
\text { site }\end{array}$ \\
\hline E Index & The entrenchment index from Bebchuk et al. (2009). & $\begin{array}{l}\text { ISS Gover- } \\
\text { nance }\end{array}$ \\
\hline $\begin{array}{l}\text { Inside and Linked } \\
\text { Vote }(\%)\end{array}$ & $\begin{array}{l}\text { Fraction of voting power held by inside and linked directors, } \\
\text { including the CEO. Data are available from } 1997 \text { onwards. }\end{array}$ & ISS Directors \\
\hline Vega & $\begin{array}{l}\text { Change in the dollar value of the CEO's wealth for a } 1 \% \text { change } \\
\text { in the annualized standard deviation of stock returns, as defined } \\
\text { in Coles et al. (2006). }\end{array}$ & $\begin{array}{l}\text { Naveen's web- } \\
\text { site }\end{array}$ \\
\hline \multicolumn{3}{|l|}{ Further } \\
\hline AcqExp/Assets (\%) & Acquisition expenses divided by the book value of assets. & Compustat \\
\hline Amihud Illiquidity & $\begin{array}{l}\text { Amihud }(2002) \text { illiquidity measure, calculated as the ratio of } \\
\text { the daily absolute stock return to the dollar trading volume } \\
{[10,000,000 \times \mid \text { Return } \mid /(\text { Price } \times \text { Volume })] \text {, averaged over the }} \\
\text { firm's fiscal year. }\end{array}$ & $C R S P$ \\
\hline Average VIX & $\begin{array}{l}\text { Mean of daily closing prices of the Chicago Board Options Ex- } \\
\text { change (CBOE) Volatility Index (VIX) of the fiscal year. }\end{array}$ & CBOE website \\
\hline
\end{tabular}


Bid-Ask

Book Leverage (\%)

CapEx/Assets (\%)

Cash/Assets (\%)

Firm Age

Forecast Inaccuracy

Market Leverage (\%)

$\operatorname{MTB}(\%)$

NetInv/Assets (\%)

PPE

PPE/Assets (\%)

$\mathrm{R} \& \mathrm{D} /$ Assets $(\%)$

ROA (\%)

Tobin's Q (\%)

Total Assets

Total Q (\%)

TotInv/Assets (\%)
Bid-ask spread from daily closing bid and ask data as in Balakrishnan et al. (2014). For each fiscal year we calculate the mean of daily $100 \times($ Ask - Bid $) /[($ Ask + Bid $) / 2]$.

Sum of long-term debt and current liabilities divided by the book value of total assets.

Capital expenditures divided by the book value of assets.

Cash and short-term investments divided by the book value of assets.

Number of years since the first trading on CRSP, with 1925 being the earliest year possible.

Absolute value of the difference between actual and forecasted earnings per share, scaled by the absolute value of actual earnings per share.

Sum of long-term debt and current liabilities divided by the sum of market equity and book debt.

Market value of equity, calculated as share price at the end of the fiscal year times the number of common shares outstanding, divided by book equity.

Total investment less sale of property, plant, and equipment divided by the book value of total assets.

Property, plant, and equipment.

Property, plant, and equipment divided by the book value of total assets.

Research and development expenditures divided by the book value of assets.

Return on assets. Net income divided by the book value of assets. Book value of assets less book value of common equity plus market value of equity divided by the book value of assets.

Book value of assets.

Market value of equity plus book value of debt minus current assets, divided by the sum of replacement costs of physical capital (property, plant, and equipment) and the replacement costs of intangible capital, as defined in Peters and Taylor (2017).

Sum of capital expenditures, acquisition expenses, and R\&D expenditures divided by the book value of assets.
$C R S P$

Compustat

Compustat

Compustat

CRSP

$I / B / E / S$

Compustat

Compustat

Compustat

Compustat

Compustat

Compustat

Compustat

Compustat

Compustat

Compustat

Compustat

This table provides an overview of the different variables used, their definitions, and the respective data sources. 
Table C.2: Propensity score model estimation

\begin{tabular}{lc}
\hline & $(1)$ \\
& Treated \\
\hline CEO Duality & $-0.2905^{* * *}$ \\
& $(0.0015)$ \\
Ln(1+CEO Tenure) & $0.2411^{* * *}$ \\
& $(0.0000)$ \\
Inside and Linked Vote & $0.0138^{* * *}$ \\
& $(0.0000)$ \\
E Index & $-0.1341^{* * *}$ \\
& $(0.0005)$ \\
Ln(Total Assets) & $-0.0774^{* *}$ \\
& $(0.0389)$ \\
Book Leverage (\%) & $0.0063^{* *}$ \\
ROA (\%) & $(0.0483)$ \\
& 0.0048 \\
Cash/Assets & $(0.3689)$ \\
R\&D/Assets & $0.0090^{* * *}$ \\
& $(0.0091)$ \\
MTB & $-0.0301^{* * *}$ \\
Constant & $(0.0100)$ \\
& -0.0001 \\
Sample Size & $(0.2240)$ \\
Pseudo R-Squared & -0.4812 \\
& $(0.1345)$ \\
\hline
\end{tabular}

This table presents the estimation results of the probit model estimated to predict the propensity score, which is the likelihood of a firm being noncompliant with the board independence requirement in fiscal year 2001. The sample includes all firm-years with necessary data from 1997 to 2000. The dependent variable Treated is a dummy variable that equals one if the firm does not comply with the board independence requirement in 2001 and zero otherwise. Variable definitions for the independent variables can be found in Table C.1 in Appendix C. The $p$-values are based on standard errors clustered at the firm level and are reported in parentheses, with *, **, and *** indicating significance levels of $10 \%, 5 \%$, and $1 \%$, respectively. 


\section{Conclusion}

This dissertation is fundamentally concerned with the question of how management and the board of directors influence the uncertainty, that is, both risk and ambiguity, of a corporation. Interest in this question stems from conflicts of interest between management and shareholders that may be resolved by an efficiently functioning board. These conflicts play a major role with respect to both dimensions of uncertainty. With regard to firm risk, conflicts arise because of different attitudes toward risk between managers and shareholders (e.g., Eisenhardt, 1989). It is thus a major concern for the board to ensure an adequate risk management by the firm (Larcker and Tayan, 2021) that enhances risky but value-enhancing decisions, yet prevents excessive risk-taking. With regard to ambiguity, I build on the literature that suggests that likely sources of ambiguity are managerial decisions that exhibit frequent changes. For shareholders, this dimension of uncertainty has a decidedly negative effect: it adversely affects the perceived attractiveness of their investment opportunities, because it leads them to overvalue negative and undervalue positive outcomes (e.g., Herron and Izhakian, 2018). Consequently, a functioning board should reduce ambiguity. The three studies constituting this dissertation address particular topics within this context. Specifically, they focus on the influence of management (Chapter 2) and the board (Chapter 3) on firm risk, as well as the board's effect on ambiguity (Chapter 4). I will briefly summarize the specific research questions and the main findings of each of the three studies in the following.

The first study (Chapter 2) examines the influence of a particular CEO characteristic, namely CEO age, on firm risk using data on sudden CEO deaths. Compared to the empirical approach applied in two recent studies on this relation (Serfling, 2014; Peltomäki et al., 2020), conducting differencein-differences (DID) analyses around sudden CEO deaths better addresses the endogenous nature inherent in such analyses. Hence, my results allow for a causal interpretation. The two main findings are, first, that CEO age indeed negatively influences firm risk, as measured by stock return volatility, yet, second, for other reasons than suggested by prior literature. In fact, higher 
firm risk associated with younger CEOs seems to be driven by the market's lack of knowledge about their abilities, rather than by the CEOs' risk-taking behavior.

The second study (Chapter 3) focuses on the relation between board size and firm risk. It considers and tests two competing explanations that might explain the negative association between board size and firm risk that has been illustrated by prior studies (Cheng, 2008; Wang, 2012). Across all firms as well as for complex ones, the evidence favors a monitoring capacity explanation, which stands in contrasts to the inefficiency explanation provided by Cheng (2008). That is, having more directors and, thus, more expertise on the board appears to improve monitoring so that lower firm risk associated with larger boards indicates a beneficial development for shareholders. For high-growth firms, on the other hand, the evidence points towards the inefficiency explanation. In those firms, communication and coordination problems seem to become severe at lower board sizes already so that the firm risk reduction indicates a detrimental development for the shareholders.

The third study (Chapter 4) is the first to analyze the board's influence on firm-level ambiguity. Using the 2003 NYSE and NASDAQ listing rule changes for our identification strategy, we find that improved board oversight induced by greater board independence can significantly reduce ambiguity for shareholders. Independent directors appear to achieve this through inducing more predictable, less fluctuating policies that are easier for shareholders to understand and to evaluate. Additionally, these reductions appear to be beneficial only for shareholders of firms operating in stable industries. In dynamic ones, independent directors seem to limit the firms' ability to carry out necessary changes.

This dissertation makes several contributions to the academic literature. While the specific contributions of each study are outlined in Chapters 2 through 4, the major contributions of this dissertation can be summarized as follows. First, in enhancing the understanding of how CEO age influences firm risk (Chapter 2), it contributes to the growing literature that analyzes the relation between individual characteristics of managers and the riskiness of the firm (e.g., Graham et al., 2013; Cain and McKeon, 2016; Bernile et al., 2017). Second, this dissertation contributes to the developing field of literature that associates aspects of board structure with measures of firm risk (e.g., Cheng, 2008; Bernile et al., 2018; Tran and Turkiela, 2020). Specifically, it establishes a more detailed picture of the effect of board size on firm risk (Chapter 3) and takes a first step in examining the board's influence on ambiguity (Chapter 4). Third, it also contributes to the growing literature analyzing ambiguity in the corporate finance context (e.g. Agliardi et al., 2016; Izhakian and Yermack, 2017; Izhakian et al., 2021). Fourth, by using data on sudden 
CEO deaths to examine the influence of a particular CEO characteristic on firm risk (Chapter 2 ), this dissertation also makes a methodological contribution. That is, it illustrates a way to generate causal evidence on how specific executive characteristics influence corporate policies and outcomes. Fifth, an additional contribution emerges from the two board studies (Chapters 3 and 4). Their findings highlight that similar board structures do not affect all kinds of firms equally and that this can lead to quite opposing explanations for the effect under study.

On the basis of this dissertation, several opportunities for future research derive. First, the empirical approach from the first study can serve as a blueprint for future studies. This one or similarly exogenous settings could be used to substantiate existing findings or reveal entirely new insights about how specific executive characteristics influence corporate policies and outcomes. Second, the differential effects of board structure in firms with certain characteristics, that is, complexity, R\&D intensity, or industry affiliation, shown in the second and third study may also be of relevance when analyzing effects of other aspects of board structure, such as board diversity or authority concentration. Future research should consider this, because it can foster the understanding of the effectiveness of certain board structures. Third, after having taken a first step in examining how board structure can affect firm-level ambiguity, there remains an open field for extensive research. Future studies can, for example, analyze if and how board characteristics other than independence (e.g., size, co-option, diversity, or authority concentration) influence ambiguity as well. Fourth, another interesting path emerges from the explanation presented in Chapter 4 that management can (inadvertently) create ambiguity for shareholders through their policy decisions. Hence, future research can examine if and how executive characteristics, such as age, overconfidence, or sensation-seeking, are associated with ambiguity. Fifth, since the interplay between executive characteristics and corporate governance and its influence on firm outcomes is an area of research that is in its infancy (Larcker and Tayan, 2021), there exist numerous opportunities to examine this interplay with a focus on firm risk or ambiguity.

Lastly, the insights from this dissertation are also of interest for practitioners. In particular, the findings from the first study have implications for the working of boards, which should foster good communication with the market when an unknown CEO is selected or choose a well-known $\mathrm{CEO}$ in the first place to diminish the CEO-related portion of firm risk. For shareholders or policy makers, the insights from this dissertation can help to implement effective board structures. To that end, the second study highlights the necessity to balance monitoring capacity advantages with potential inefficiencies when choosing a board's size. The third study underscores the importance of independent directors when it comes to reducing ambiguity. In addition, the 
second and third study both illustrate that effects of certain board characteristics vary with particular firm characteristics, which supports critics of one-size-fits-all approaches in corporate governance. 


\section{Bibliography}

Adam, T. and V. K. Goyal (2008). The investment opportunity set and its proxy variables. Journal of Financial Research 31(1), 41-63.

Adams, R. B., B. E. Hermalin, and M. S. Weisbach (2010). The role of boards of directors in corporate governance: A conceptual framework and survey. Journal of Economic Literature 48(1), $58-107$.

Adams, R. B. and H. Mehran (2012). Bank board structure and performance: Evidence for large bank holding companies. Journal of Financial Intermediation 21(2), 243-267.

Agarwal, V., Y. E. Arisoy, and N. Y. Naik (2017). Volatility of aggregate volatility and hedge fund returns. Journal of Financial Economics 125(3), 491-510.

Agliardi, E., R. Agliardi, and W. Spanjers (2016). Corporate financing decisions under ambiguity: Pecking order and liquidity policy implications. Journal of Business Research 69(12), 6012 6020 .

Aktas, N., A. Boone, E. Croci, and A. Signori (2021). Reductions in CEO career horizons and corporate policies. Journal of Corporate Finance 66, 101862.

Amihud, Y. (2002). Illiquidity and stock returns: Cross-section and time-series effects. Journal of Financial Markets 5(1), 31-56.

Amihud, Y. and B. Lev (1981). Risk reduction as a managerial motive for conglomerate mergers. Bell Journal of Economics 12(2), 605-617.

Arellano, M. and S. Bond (1991). Some tests of specification for panel data: Monte Carlo evidence and an application to employment equations. Review of Economic Studies 58(2), 277-297. 
Arellano, M. and O. Bover (1995). Another look at the instrumental variable estimation of error-components models. Journal of Econometrics 68(1), 29-51.

Armstrong, C. S., J. E. Core, and W. R. Guay (2014). Do independent directors cause improvements in firm transparency? Journal of Financial Economics 113(3), 383-403.

Arping, S. and Z. Sautner (2010). Corporate governance and leverage: Evidence from a natural experiment. Finance Research Letters 7(2), 127-134.

Audretsch, D., A. Coad, and A. Segarra (2014). Firm growth and innovation. Small Business Economics 43(4), 743-749.

Augustin, P. and Y. Izhakian (2020). Ambiguity, volatility, and credit risk. Review of Financial Studies 33(4), 1618-1672.

Balakrishnan, K., M. B. Billings, B. Kelly, and A. Ljungqvist (2014). Shaping liquidity: On the causal effects of voluntary disclosure. Journal of Finance 69(5), 2237-2278.

Balsmeier, B., L. Fleming, and G. Manso (2017). Independent boards and innovation. Journal of Financial Economics 123(3), 536-557.

Baltussen, G., S. van Bekkum, and B. van der Grient (2018). Unknown unknowns: Uncertainty about risk and stock returns. Journal of Financial \& Quantitative Analysis 53(4), 1615-1651.

Banerjee, S., M. Humphery-Jenner, and V. Nanda (2015). Restraining overconfident CEOs through improved governance: Evidence from the Sarbanes-Oxley Act. Review of Financial Studies 28(10), 2812-2858.

Bansal, R., D. Kiku, I. Shaliastovich, and A. Yaron (2014). Volatility, the macroeconomy, and asset prices. Journal of Finance 69(6), 2471-2511.

Bargeron, L. L., K. M. Lehn, and C. J. Zutter (2010). Sarbanes-Oxley and corporate risk-taking. Journal of Accounting \& Economics 49(1/2), 34-52.

Barker, V. L. and G. C. Mueller (2002). CEO characteristics and firm R\&D spending. Management Science 48(6), 782-801.

Baysinger, B. D., R. D. Kosnik, and T. A. Turk (1991). Effects of board and ownership structure on corporate R\&D strategy. Academy of Management Journal 34(1), 205-214. 
Bebchuk, L., A. Cohen, and A. Ferrell (2009). What matters in corporate governance? Review of Financial Studies 22(2), 783-827.

Belloc, F. (2012). Corporate governance and innovation: A survey. Journal of Economic Surveys 26(5), 835-864.

Bennedsen, M., F. Perez-Gonzalez, and D. Wolfenzon (2020). Do CEOs matter? Evidence from hospitalization events. Journal of Finance 75(4), 1877-1911.

Benner, M. J. and T. Zenger (2016). The lemons problem in markets for strategy. Strategy Science 1(2), 71-89.

Berger, L. and L. Eeckhoudt (2021). Risk, ambiguity, and the value of diversification. Management Science 67(3), 1639-1647.

Berle, A. A. and G. G. C. Means (1932). The modern corporation and private property. New York: The Macmillan Company.

Bernile, G., V. Bhagwat, and P. R. Rau (2017). What doesn't kill you will only make you more risk-loving: Early-life disasters and CEO behavior. Journal of Finance 72(1), 167-206.

Bernile, G., V. Bhagwat, and S. Yonker (2018). Board diversity, firm risk, and corporate policies. Journal of Financial Economics 127(3), 588-612.

Bertrand, M. and A. Schoar (2003). Managing with style: The effect of managers on firm policies. Quarterly Journal of Economics 118(4), 1169-1208.

Bhagat, S. and B. Black (1999). The uncertain relationship between board composition and firm performance. Business Lawyer 54(3), 921-963.

Blundell, R. and S. Bond (1998). Initial conditions and moment restrictions in dynamic panel data models. Journal of Econometrics 87(1), 115-143.

Boivie, S., M. K. Bednar, R. V. Aguilera, and J. L. Andrus (2016). Are boards designed to fail? The implausibility of effective board monitoring. Academy of Management Annals 10(1), 319-407.

Bollerslev, T., N. Sizova, and G. Tauchen (2012). Volatility in equilibrium: Asymmetries and dynamic dependencies. Review of Finance 16(1), 31-80. 
Boone, A. L., L. Casares Field, J. M. Karpoff, and C. G. Raheja (2007). The determinants of corporate board size and composition: An empirical analysis. Journal of Financial Economics 85(1), 66-101.

Borokhovich, K. A., T. J. Boulton, K. R. Brunarski, and Y. S. Harman (2014). The incentives of grey directors: Evidence from unexpected executive and board chair turnover. Journal of Corporate Finance 28, 102-115.

Borokhovich, K. A., K. R. Brunarski, M. S. Donahue, and Y. S. Harman (2006). The importance of board quality in the event of a CEO death. Financial Review 41(3), 307-337.

Bowman, E. H. (1963). Consistency and optimality in managerial decision making. Management Science 9(2), 310-321.

Boyarchenko, N. (2012). Ambiguity shifts and the 2007-2008 financial crisis. Journal of Monetary Economics 59(5), 493-507.

Brenner, M. and Y. Izhakian (2018). Asset pricing and ambiguity: Empirical evidence. Journal of Financial Economics 130(3), 503-531.

Brickley, J. A., J. L. Coles, and R. L. Terry (1994). Outside directors and the adoption of poison pills. Journal of Financial Economics 35(3), 371-390.

Byrd, J. W. and K. A. Hickman (1992). Do outside directors monitor managers? Journal of Financial Economics 32(2), 195-221.

Cain, M. D. and S. B. McKeon (2016). CEO personal risk-taking and corporate policies. Journal of Financial and Quantitative Analysis 51(1), 139-164.

Cameron, A. C. and P. K. Trivedi (2010). Microeconometrics Using Stata, Revised Edition (2nd ed.). Stata Press.

Campbell, J. Y., S. Giglio, C. Polk, and R. Turley (2018). An intertemporal CAPM with stochastic volatility. Journal of Financial Economics 128(2), 207-233.

Carr, P. and R. Lee (2009). Volatility derivatives. Annual Review of Financial Economics 1(1), 319-339. 
Cassell, C. A., S. X. Huang, J. M. Sanchez, and M. D. Stuart (2012). Seeking safety: The relation between CEO inside debt holdings and the riskiness of firm investment and financial policies. Journal of Financial Economics 103(3), 588-610.

Chakravarthy, B. S. (1982). Adaptation: A promising metaphor for strategic management. Academy of Management Review 7(1), 35-44.

Chan, L. K., J. Lakonishok, and T. Sougiannis (2001). The stock market valuation of research and development expenditures. Journal of Finance 56(6), 2431-2456.

Charness, G. and U. Gneezy (2010). Portfolio choice and risk attitudes: An experiment. Economic Inquiry 48(1), 133-146.

Chen, H. J., M. Kacperczyk, and H. Ortiz-Molina (2011). Labor unions, operating flexibility, and the cost of equity. Journal of Financial and Quantitative Analysis 46(1), 25-58.

Chen, J., W. S. Leung, and M. Goergen (2017). The impact of board gender composition on dividend payouts. Journal of Corporate Finance 43, 86-105.

Chen, Y., A. Goyal, and L. Zolotoy (2021). Global board reforms and the pricing of IPOs. Journal of Financial and Quantitative Analysis, 1-51.

Chen, Z. and L. Epstein (2002). Ambiguity, risk, and asset returns in continuous time. Econometrica $70(4), 1403-1443$.

Cheng, S. (2008). Board size and the variability of corporate performance. Journal of Financial Economics 87(1), 157-176.

Cheng, S., J. H. Evans, and N. J. Nagarajan (2008). Board size and firm performance: The moderating effects of the market for corporate control. Review of Quantitative Finance and Accounting 31, 121-145.

Chevalier, J. and G. Ellison (1999). Career concerns of mutual fund managers. Quarterly Journal of Economics 114(2), 389-432.

Chhaochharia, V. and Y. Grinstein (2007). Corporate governance and firm value: The impact of the 2002 governance rules. Journal of Finance 62(4), 1789-1825. 
Christy, J. A., Z. P. Matolcsy, A. Wright, and A. Wyatt (2013). Do board characteristics influence the shareholders' assessment of risk for small and large firms? Abacus 49(2), 161-196.

Cline, B. N. and A. S. Yore (2016). Silverback CEOs: Age, experience, and firm value. Journal of Empirical Finance 35, 169-188.

Coiculescu, G., Y. Izhakian, and S. A. Ravid (2019). Innovation under ambiguity and risk. Working paper, Baruch College Zicklin School.

Coles, J. L., N. D. Daniel, and L. Naveen (2006). Managerial incentives and risk-taking. Journal of Financial Economics 79(2), 431-468.

Coles, J. L., N. D. Daniel, and L. Naveen (2008). Boards: Does one size fit all? Journal of Financial Economics 87(2), 329-356.

Coles, J. L., N. D. Daniel, and L. Naveen (2014). Co-opted boards. Review of Financial Studies 27(6), 1751-1796.

Combs, J. G., D. J. J. Ketchen, A. A. Perryman, and M. S. Donahue (2007). The moderating effect of CEO power on the board composition-firm performance relationship. Journal of Management Studies 44(8), 1299-1323.

Conyon, M. J. and S. I. Peck (1998). Board size and corporate performance: Evidence from European countries. European Journal of Finance 4(3), 291-304.

Cotter, J. F., A. Shivdasani, and M. Zenner (1997). Do independent directors enhance target shareholder wealth during tender offers? Journal of Financial Economics 43(2), 195-218.

Cremers, K. J. M. and V. B. Nair (2005). Governance mechanisms and equity prices. Journal of Finance 60(6), 2859-2894.

Croci, E., A. Giudice, and H. Jankensgård (2017). CEO age, risk incentives, and hedging strategy. Financial Management 46(3), 687-716.

Darrat, A. F., S. Gray, J. C. Park, and Y. Wu (2016). Corporate governance and bankruptcy risk. Journal of Accounting, Auditing E Finance 31(2), 163-202.

Dechow, P. M., R. G. Sloan, and A. P. Sweeney (1995). Detecting earnings management. Accounting Review 70(2), 193-225. 
Dehejia, R. H. and S. Wahba (2002). Propensity score-matching methods for nonexperimental causal studies. Review of Economics \& Statistics 84(1), 151-161.

Denis, D. K. and J. J. McConnell (2003). International corporate governance. Journal of Financial and Quantitative Analysis 38(1), 1-36.

Dess, G. G. and D. W. Beard (1984). Dimensions of organizational task environments. Administrative Science Quarterly 29(1), 52-73.

Drechsler, I. (2013). Uncertainty, time-varying fear, and asset prices. Journal of Finance 68(5), $1843-1889$.

Duchin, R., J. G. Matsusaka, and O. Ozbas (2010). When are outside directors effective? Journal of Financial Economics 96(2), 195-214.

Easley, D. and M. O'Hara (2009). Ambiguity and nonparticipation: The role of regulation. Review of Financial Studies 22(5), 1817-1843.

Easterbrook, F. H. (1984). Two agency-cost explanations of dividends. American Economic Review 74(4), 650-659.

Eisenberg, T., S. Sundgren, and M. T. Wells (1998). Larger board size and decreasing firm value in small firms. Journal of Financial Economics 48(1), 35-54.

Eisenhardt, K. M. (1989). Agency theory: An assessment and review. Academy of Management Review 14(1), 57-74.

Ellsberg, D. (1961). Risk, ambiguity, and the savage axioms. Quarterly Journal of Economics $75(4), 643-669$.

Epstein, L. G. and S. Ji (2013, 04). Ambiguous volatility and asset pricing in continuous time. Review of Financial Studies 26(7), 1740-1786.

Epstein, L. G. and M. Schneider (2008). Ambiguity, information quality, and asset pricing. Journal of Finance 63(1), 197-228.

Eraker, B. and I. Shaliastovich (2008). An equilibrium guide to designing affine pricing models. Mathematical Finance 18(4), 519-543. 
Etebari, A., J. O. Horrigan, and J. L. Landwehr (1987). To be or not to be - Reaction of stock returns to sudden deaths of corporate chief executive officers. Journal of Business Finance 6 Accounting 14(2), 255-278.

Fahlenbrach, R. (2009). Founder-CEOs, investment decisions, and stock market performance. Journal of Financial $\&$ Quantitative Analysis 44(2), 439-466.

Fama, E. F. (1980). Agency problems and the theory of the firm. Journal of Political Economy $88(2), 288-307$.

Fee, C. E., C. J. Hadlock, and J. R. Pierce (2013). Managers with and without style: Evidence using exogenous variation. Review of Financial Studies 26(3), 567-601.

Ferris, S. P., D. Javakhadze, and T. Rajkovic (2017). CEO social capital, risk-taking and corporate policies. Journal of Corporate Finance 47, 46-71.

Fields, M. A. and P. Y. Keys (2003). The emergence of corporate governance from Wall St. to Main St.: Outside directors, board diversity, earnings management, and managerial incentives to bear risk. Financial Review 38(1), 1-24.

Garlappi, L., R. Giammarino, and A. Lazrak (2017). Ambiguity and the corporation: Group disagreement and underinvestment. Journal of Financial Economics 125(3), 417-433.

Giannetti, M. and M. Zhao (2019). Board ancestral diversity and firm performance volatility. Journal of Financial and Quantitative Analysis 54(3), 1117-1155.

Gibbons, R. and K. J. Murphy (1992). Optimal incentive contracts in the presence of career concerns: Theory and evidence. Journal of Political Economy 100(3), 468-505.

Gormley, T. A. and D. A. Matsa (2016). Playing it safe? Managerial preferences, risk, and agency conflicts. Journal of Financial Economics 122(3), 431-455.

Graham, J. R., C. R. Harvey, and M. Puri (2013). Managerial attitudes and corporate actions. Journal of Financial Economics 109(1), 103-121.

Griffin, J. M. and M. L. Lemmon (2002). Book-to-market equity, distress risk, and stock returns. Journal of Finance 57(5), 2317-2336. 
Guo, L. and R. W. Masulis (2015). Board structure and monitoring: New evidence from CEO turnovers. Review of Financial Studies 28(10), 2770-2811.

Hall, B. H., A. Jaffe, and M. Trajtenberg (2005). Market value and patent citations. RAND Journal of Economics 36(1), 16-38.

Hambrick, D. C. and P. A. Mason (1984). Upper echelons: The organization as a reflection of its top managers. Academy of Management Review 9(2), 193-206.

Harris, M. and A. Raviv (1979). Optimal incentive contracts with imperfect information. Journal of Economic Theory 20(2), 231-259.

Harris, M. and A. Raviv (2008). A theory of board control and size. Review of Financial Studies 21(4), 1797-1832.

Hayes, R. M. and S. Schaefer (1999). How much are differences in managerial ability worth? Journal of Accounting and Economics 27(2), 125-148.

Hermalin, B. E. and M. S. Weisbach (2003). Boards of directors as an endogenously determined institution: A survey of the economic literature. Economic Policy Review 9(1), 7-26.

Herron, R. and Y. Izhakian (2018). Ambiguity, risk, and payout policy. Working paper, Northeastern University.

Herron, R. and Y. Izhakian (2020). Mergers and acquisitions: The role of ambiguity. Working paper, Northeastern University.

Hirshleifer, D. and A. V. Thakor (1992). Managerial conservatism, project choice, and debt. Review of Financial Studies 5(3), 437-470.

Hogarth, R. M. and S. Makridakis (1981). The value of decision making in a complex environment: An experimental approach. Management Science 27(1), 93-107.

Holmström, B. (1999). Managerial incentive problems: A dynamic perspective. Review of Economic Studies 66(1), 169-182.

Holmström, B. and J. Ricart I Costa (1986). Managerial incentives and capital management. Quarterly Journal of Economics 101(4), 835-860. 
Hong, H., J. D. Kubik, and A. Solomon (2000). Security analysts' career concerns and herding of earnings forecasts. RAND Journal of Economics 31(1), 121-144.

Hou, K., P.-H. Hsu, S. Wang, A. Watanabe, and Y. Xu (2021). Corporate R\&D and stock returns: International evidence. Journal of Financial and Quantitative Analysis, 1-72.

Hu, J., S. Li, A. G. Taboada, and F. Zhang (2020). Corporate board reforms around the world and stock price crash risk. Journal of Corporate Finance 62, 101557.

Huang, D., C. Schlag, I. Shaliastovitch, and J. Thimme (2019). Volatility-of-volatility risk. Journal of Financial and Quantitative Analysis 54 (6), 2423-2452.

Humphery-Jenner, M., E. Islam, L. Rahman, and J.-A. Suchard (2019). Corporate governance and powerful CEOs. Working paper, UNSW.

Iacus, S. M., G. King, and G. Porro (2011). Multivariate matching methods that are monotonic imbalance bounding. Journal of the American Statistical Association 106(493), 345-361.

Iacus, S. M., G. King, and G. Porro (2012). Causal inference without balance checking: Coarsened exact matching. Political Analysis 20(1), 1-24.

Izhakian, Y. (2020). A theoretical foundation of ambiguity measurement. Journal of Economic Theory 187, 105001.

Izhakian, Y. and D. Yermack (2017). Risk, ambiguity, and the exercise of employee stock options. Journal of Financial Economics 124(1), 65-85.

Izhakian, Y., D. Yermack, and J. F. Zender (2021). Ambiguity and the tradeoff theory of capital structure. Management Science (forthcoming).

Jensen, M. C. (1986). Agency costs of free cash flow, corporate finance, and takeovers. American Economic Review 76(2), 323-329.

Jensen, M. C. (1993). The modern industrial revolution, exit, and the failure of internal control systems. Journal of Finance 48(3), 831-880.

Jensen, M. C. and W. H. Meckling (1976). Theory of the firm: Managerial behavior, agency costs and ownership structure. Journal of Financial Economics 3(4), 305-360. 
Jenter, D. and F. Kanaan (2015). CEO turnover and relative performance evaluation. Journal of Finance 70(5), 2155-2184.

Jenter, D. and K. Lewellen (2015). CEO preferences and acquisitions. Journal of Finance 70(6), $2813-2852$.

Jenter, D., E. Matveyev, and L. Roth (2016). Good and bad CEOs. Working paper, London School of Economics.

Jiraporn, P., J.-C. Kim, and Y. S. Kim (2011). Dividend payouts and corporate governance quality: An empirical investigation. Financial Review 46(2), 251-279.

Jiraporn, P., J.-C. Kim, Y. S. Kim, and P. Kitsabunnarat (2012). Capital structure and corporate governance quality: Evidence from the Institutional Shareholder Services (ISS). International Review of Economics \& Finance 22(1), 208-221.

John, K. and L. W. Senbet (1998). Corporate governance and board effectiveness. Journal of Banking \& Finance 22(4), 371-403.

Johnson, W. B., R. P. Magee, N. J. Nagarajan, and H. A. Newman (1985). An analysis of the stock price reaction to sudden executive deaths: Implications for the managerial labor market. Journal of Accounting and Economics 7(1-3), 151-174.

Jones, J. J. (1991). Earnings management during import relief investigations. Journal of Accounting Research 29(2), 193-228.

Ju, N. and J. Miao (2012). Ambiguity, learning, and asset returns. Econometrica 80(2), 559-591.

Kang, J.-K., W.-L. Liu, A. Low, and L. Zhang (2018). Friendly boards and innovation. Journal of Empirical Finance 45, 1-25.

Kaplan, S. N., M. M. Klebanov, and M. Sorensen (2012). Which CEO characteristics and abilities matter? Journal of Finance 67(3), 973-1007.

Kim, Y., H. Li, and S. Li (2014). Corporate social responsibility and stock price crash risk. Journal of Banking \&3 Finance 43, 1-13.

Kini, O. and R. Williams (2012). Tournament incentives, firm risk, and corporate policies. Journal of Financial Economics 103(2), 350-376. 
Kirkpatrick, G. (2009). The corporate governance lessons from the financial crisis. OECD Journal: Financial Market Trends 1, 61-87.

Klein, A. (2002). Audit committee, board of director characteristics, and earnings management. Journal of Accounting E3 Economics 33(3), 375-400.

Klibanoff, P., M. Marinacci, and S. Mukerji (2005). A smooth model of decision making under ambiguity. Econometrica 73(6), 1849-1892.

Knight, F. H. (1921). Risk, uncertainty and profit. Boston: Houghton Mifflin.

Knyazeva, A., D. Knyazeva, and R. W. Masulis (2013). The supply of corporate directors and board independence. Review of Financial Studies 26(6), 1561-1605.

Kogan, L., D. Papanikolaou, A. Seru, and N. Stoffman (2017, 03). Technological innovation, resource allocation, and growth. Quarterly Journal of Economics 132(2), 665-712.

Kor, Y. Y. and J. T. Mahoney (2005). How dynamics, management, and governance of resource deployments influence firm-level performance. Strategic Management Journal 26(5), 489 - 496.

Kothari, S. P., T. E. Laguerre, and A. J. Leone (2002). Capitalization versus expensing: Evidence on the uncertainty of future earnings from capital expenditures versus R\&D outlays. Review of Accounting Studies 7(4), 355-382.

Kunreuther, H. (1969). Extensions of Bowman's theory on managerial decision-making. Management Science 15(8), B-415.

Lamont, O. A. (2002). Macroeconomic forecasts and microeconomic forecasters. Journal of Economic Behavior and Organization 48(3), 265-280.

Larcker, D. and B. Tayan (2021). Corporate Governanvce Matters: A Closer Look at Organizational Choices and Their Consequences (3rd ed.). Pearson Education.

Larson, J. A. (1999). Stock price reactions of small public firms to the loss of the CEO. Journal of Small Business Management 37(3), 15-24.

Lecuona, J. R. and M. Reitzig (2014). Knowledge worth having in 'excess': The value of tacit and firm-specific human resource slack. Strategic Management Journal 35(7), 954-973. 
Lehn, K. M., S. Patro, and M. Zhao (2009). Determinants of the size and composition of US corporate boards: 1935-2000. Financial Management 38(4), 747-780.

Lev, B. (1974). On the association between operating leverage and risk. Journal of Financial $\&$ Quantitative Analysis 9(4), 627-641.

Lewellen, K. (2006). Financing decisions when managers are risk averse. Journal of Financial Economics 82(3), 551-589.

Li, X., A. Low, and A. K. Makhija (2017). Career concerns and the busy life of the young CEO. Journal of Corporate Finance 47, 88-109.

Lin, C., Y. Ma, P. Malatesta, and Y. Xuan (2011). Ownership structure and the cost of corporate borrowing. Journal of Financial Economics 100(1), 1-23.

Lin, C., M. S. Officer, and H. Zou (2011). Directors' and officers' liability insurance and acquisition outcomes. Journal of Financial Economics 102(3), 507-525.

Linck, J. S., J. M. Netter, and T. Yang (2008). The determinants of board structure. Journal of Financial Economics 87(2), 308-328.

Linck, J. S., J. M. Netter, and T. Yang (2009). The effects and unintended consequences of the Sarbanes-Oxley Act on the supply and demand for directors. Review of Financial Studies 22(8), $3287-3328$.

Litov, L. P., P. Moreton, and T. R. Zenger (2012). Corporate strategy, analyst coverage, and the uniqueness paradox. Management Science 58(10), 1797-1815.

Liu, Y., M. K. Miletkov, Z. Wei, and T. Yang (2015). Board independence and firm performance in China. Journal of Corporate Finance 30, 223-244.

Mak, Y. and Y. Kusnadi (2005). Size really matters: Further evidence on the negative relationship between board size and firm value. Pacific-Basin Finance Journal 13(3), 301-318.

Malmendier, U. and G. Tate (2008). Who makes acquisitions? CEO overconfidence and the market's reaction. Journal of Financial Economics 89(1), 20-43. 
Mandelker, G. N. and S. G. Rhee (1984). The impact of the degrees of operating and financial leverage on systematic risk of common stock. Journal of Financial E Quantitative Analysis 19(1), 45-57.

Masulis, R. W., C. Wang, F. Xie, and S. Zhang (2020). Directors: Older and wiser, or too old to govern? Working paper, UNSW.

Merz, A. and J. F. Weidemann (2018). What really matters in CEO succession? Evidence from sudden CEO deaths. Working paper, University of Goettingen.

Mitchell, J. R., D. A. Shepherd, and M. P. Sharfman (2011). Erratic strategic decisions: when and why managers are inconsistent in strategic decision making. Strategic Management Journal 32(7), 683-704.

Mukerji, S. and J.-M. Tallon (2001). Ambiguity aversion and incompleteness of financial markets. Review of Economic Studies 68(4), 883-904.

Nakano, M. and P. Nguyen (2012). Board size and corporate risk taking: Further evidence from Japan. Corporate Governance: An International Review 20(4), 369-387.

Nguyen, B. D. and K. M. Nielsen (2010). The value of independent directors: Evidence from sudden deaths. Journal of Financial Economics 98(3), 550-567.

Nguyen, B. D. and K. M. Nielsen (2014). What death can tell: Are executives paid for their contributions to firm value? Management Science 60(12), 2994-3010.

Nguyen, L., L. Vu, and X. Yin (2021). The bright side of co-opted boards: Evidence from firm innovation. Financial Review 56, 29-53.

Norden, L. and S. van Kampen (2013). Corporate leverage and the collateral channel. Journal of Banking \& Finance 37(12), 5062-5072.

OECD (2015). G20/OECD Principles of Corporate Governance. Paris: OECD Publishing.

Opler, T., L. Pinkowitz, R. Stulz, and R. Williamson (1999). The determinants and implications of corporate cash holdings. Journal of Financial Economics 52(1), 3-46.

Packard, M. D. and B. B. Clark (2020). On the mitigability of uncertainty and the choice between predictive and nonpredictive strategy. Academy of Management Review 45(4), 766-786. 
Pan, Y., T. Y. Wang, and M. S. Weisbach (2015). Learning about CEO ability and stock return volatility. Review of Financial Studies 28(6), 1623-1666.

Peasnell, K. V., P. F. Pope, and S. Young (2005). Board monitoring and earnings management: Do outside directors influence abnormal accruals? Journal of Business Finance 85 Accounting 32(78), 1311-1346.

Peltomäki, J., J. Sihvonen, S. Swidler, and S. Vähämaa (2020). Age, gender, and risk-taking: Evidence from the S\&P 1500 executives and market-based measures of firm risk. Working paper, Stockholm University, Stockholm Business School.

Peters, F. S. and A. F. Wagner (2014). The executive turnover risk premium. Journal of Finance 69(4), 1529-1563.

Peters, R. H. and L. A. Taylor (2017). Intangible capital and the investment-q relation. Journal of Financial Economics 123(2), 251-272.

Pflug, G. and D. Wozabal (2007). Ambiguity in portfolio selection. Quantitative Finance 7(4), 435-442.

Prendergast, C. and L. Stole (1996). Impetuous youngsters and jaded old-timers: Acquiring a reputation for learning. Journal of Political Economy 104(6), 1105-1134.

Price, R., F. J. Román, and B. Rountree (2011). The impact of governance reform on performance and transparency. Journal of Financial Economics 99(1), 76-96.

Quigley, T. J., C. Crossland, and R. J. Campbell (2017). Shareholder perceptions of the changing impact of CEOs: Market reactions to unexpected CEO deaths, 1950-2009. Strategic Management Journal 38(4), 939-949.

Raheja, C. G. (2005). Determinants of board size and composition: A theory of corporate boards. Journal of Financial \& Quantitative Analysis 40(2), 283-306.

Remus, W. E. (1978). Testing Bowman's managerial coefficient theory using a competitive gaming environment. Management Science 24(8), 827-835.

Rivkin, J. W. (2000). Imitation of complex strategies. Management Science 46(6), 824-844. 
Roberts, M. R. and T. M. Whited (2013). Endogeneity in empirical corporate finance. In G. M. Constantinides, M. Harris, and R. M. Stulz (Eds.), Handbook of the Economics of Finance, Volume 2, pp. 493-572. Amsterdam: Elsevier.

Rosenbaum, P. R. and D. B. Rubin (1983). The central role of the propensity score in observational studies for causal effects. Biometrika $70(1), 41-55$.

Sah, R. D. and J. E. Stiglitz (1991). The quality of managers in centralized versus decentralized organizations. Quarterly Journal of Economics 106(1), 289-295.

Sah, R. K. and J. E. Stiglitz (1986). The architecture of economic systems: Hierarchies and polyarchies. American Economic Review 76(4), 716-727.

Salas, J. M. (2010). Entrenchment, governance, and the stock price reaction to sudden executive deaths. Journal of Banking and Finance 34(3), 656-666.

Scharfstein, D. S. and J. C. Stein (1990). Herd behavior and investment. American Economic Review 80(3), 465-479.

Schwert, G. W. (1989). Why does stock market volatility change over time? Journal of Finance 44(5), 1115-1153.

Serfling, M. A. (2014). CEO age and the riskiness of corporate policies. Journal of Corporate Finance 25, 251-273.

Shepherd, N. G. and J. M. Rudd (2014). The influence of context on the strategic decision-making process: A review of the literature. International Journal of Management Reviews 16(3), $340-364$.

Shi, W., R. E. Hoskisson, and Y. A. Zhang (2017). Independent director death and CEO acquisitiveness: Build an empire or pursue a quiet life? Strategic Management Journal 38(3), 780-792.

Shipman, J. E., Q. T. Swanquist, and R. L. Whited (2017). Propensity score matching in accounting research. Accounting Review 92(1), 213-244.

Sila, V., A. Gonzalez, and J. Hagendorff (2016). Women on board: Does boardroom gender diversity affect firm risk? Journal of Corporate Finance 36, 26-53. 
Simerly, R. L. and M. Li (2000). Environmental dynamism, capital structure and performance: a theoretical integration and an empirical test. Strategic Management Journal 21(1), 31-49.

Souther, M. E. (2021). Does board independence increase firm value? Evidence from closed-end funds. Journal of Financial and Quantitative Analysis 56(1), 313-336.

Stuart, E. A. (2010, 02). Matching methods for causal inference: A review and a look forward. Statistical Science 25(1), 1-21.

Tran, H. and J. Turkiela (2020). The powers that be: Concentration of authority within the board of directors and variability in firm performance. Journal of Corporate Finance 60, 101537.

Trautmann, S. T. and G. Van De Kuilen (2015). Ambiguity attitudes. In G. Keren and G. Wu (Eds.), Blackwell handbook of judgment and decision making, Volume 1, pp. 89-116. Oxford: Basil Blackwell.

Wang, C.-J. (2012). Board size and firm risk-taking. Review of Quantitative Finance \& Accounting 38(4), 519-542.

Wang, H., R. J. Wuebker, S. Han, and M. D. Ensley (2012). Strategic alliances by venture capital backed firms: An empirical examination. Small Business Economics 38(2), 179-196.

Wang, Y. and S. Yin (2020). Hiring retirement-age CEOs. European Financial Management forthcoming.

Weber, R. A. (2006). Managing growth to achieve efficient coordination in large groups. American Economic Review 96(1), 114-126.

Wei, J., W. Hualin, and Z. Shan (2016). Reputation concerns of independent directors: Evidence from individual director voting. Review of Financial Studies 29(3), 655-696.

Williams, C. D. (2014, 07). Asymmetric responses to earnings news: A case for ambiguity. Accounting Review 90(2), 785-817.

Wintoki, M. B. (2007). Corporate boards and regulation: The effect of the Sarbanes-Oxley Act and the exchange listing requirements on firm value. Journal of Corporate Finance 13(2), $229-250$. 
Wintoki, M. B., J. S. Linck, and J. M. Netter (2012). Endogeneity and the dynamics of internal corporate governance. Journal of Financial Economics 105(3), 581-606.

Worrell, D. L. and W. N. Davidson (1987). The effect of CEO succession on stockholder wealth in large firms following the death of the predecessor. Journal of Management 13(3), 509-515.

Worrell, D. L. and W. N. Davidson (1989). The death of key executives in small firms: Effects on investor wealth. Journal of Small Business Management 27(2), 10-16.

Worrell, D. L., W. N. Davidson, P. Chandy, and S. L. Garrison (1986). Manangement turnover through deaths of key executives: Effects on investor wealth. Academy of Management Journal 29(4), 674-694.

Wu, B. and A. M. Knott (2006). Entrepreneurial risk and market entry. Management Science 52(9), 1315-1330.

Xiang, E., D. Gasbarro, G. Cullen, and W. Ruan (2020). Does R\&D expenditure volatility affect stock return? Journal of Contemporary Accounting E Economics 16(3), 100211.

Xie, B., W. N. Davidson, and P. J. DaDalt (2003). Earnings management and corporate governance: The role of the board and the audit committee. Journal of Corporate Finance 9(3), 295-316.

Yang, T. and S. Zhao (2014). CEO duality and firm performance: Evidence from an exogenous shock to the competitive environment. Journal of Banking $\mathscr{E}$ Finance 49, 534-552.

Yermack, D. (1996). Higher market valuation of companies with a small board of directors. Journal of Financial Economics 40(2), 185-211.

Yim, S. (2013). The acquisitiveness of youth: CEO age and acquisition behavior. Journal of Financial Economics 108(1), 250-273.

Zhang, T., S. Sabherwal, N. Jayaraman, and S. P. Ferris (2016). The young and the restless: A study of age and acquisition propensity of CEOs of UK firms. Journal of Business Finance and Accounting 43(9-10), 1385-1419.

Zwiebel, J. (1995). Corporate conservatism and relative compensation. Journal of Political Economy 103(1), 1-25. 


\section{Statement of contribution}

\section{to each paper of the cumulative dissertation}

To the three papers of the cumulative dissertation, I personally contributed as follows:

1. to the paper Do Younger CEOs Really Increase Firm Risk? Evidence from Sudden CEO Deaths (single-author paper): conceptualization, empirical analysis, and writing, in total: $100 \%$,

2. to the paper Board Size, Firm Type, and Stock Return Volatility co-authored by Alexander Merz: significant contributions to the conceptualization, empirical analysis, and writing, in total: $55 \%$, and

3. to the paper Board Structure and Ambiguity co-authored by Alexander Merz: significant contributions to the conceptualization, empirical analysis, and writing, in total: $60 \%$.

Göttingen, 07.05.2021

Place, Date

Sebastian Trabert 


\section{Ph.D. program in Economics}

\section{Declaration for admission to the doctoral examination}

\section{I confirm}

1. that the dissertation "Firm Risk and Ambiguity: The Role of Management and the Board" that I submitted was produced independently without assistance from external parties, and not contrary to high scientific standards and integrity,

2. that I have adhered to the examination regulations, including upholding a high degree of scientific integrity, which includes the strict and proper use of citations so that the inclusion of other ideas in the dissertation are clearly distinguished,

3. that in the process of completing this doctoral thesis, no intermediaries were compensated to assist me neither with the admissions or preparation processes, and in this process,

- no remuneration or equivalent compensation were provided

- no services were engaged that may contradict the purpose of producing a doctoral thesis

4. that I have not submitted this dissertation or parts of this dissertation elsewhere.

I am aware that false claims (and the discovery of those false claims now, and in the future) with regards to the declaration for admission to the doctoral examination can lead to the invalidation or revoking of the doctoral degree.

Göttingen, 07.05.2021

Place, Date

Sebastian Trabert 